\title{
Comparative Techniques for Nuclear Fuel Cycle Waste Management Systems
}
P. J. Pelto
J. W. Voss

September 1979

Prepared for the U.S. Department of Energy under Contract EY-76-C-06-1830

Pacific Northwest Laboratory Operated for the U.S. Department of Energy by Battelle Memorial Institute 


\title{
NOTICE
}

This report was prepared as an account of work sponsored by the United States Government. Neither the United States nor the Department of Energy, nor any of their employees, nor any of their contractors, subcontractors, or their employees, makes any warranty, express or implied, or assumes any legal liability or responsibility for the accuracy, completeness or usefulness of any information, apparatus, product or process disclosed, or represents that its use would not infringe privately owned rights.

The views, opinions and conclusions contained in this report are those of the contractor and do not necessarily represent those of the United States Government or the United States Department of Energy.

\author{
PACIFIC NORTHWEST LABORATORY \\ operated by \\ BATTELLE \\ for the \\ UNITED STATES DEPARTMENT OF ENERGY \\ Under Contract EY-76-C-06-1830
}
Printed in the United States of America Available from
National Technical Information Service United States Department of Commerce 5285 Port Royal Road
Springfield, Virginia 22151

Price: Printed Copy $\$ \_$; Microfiche $\$ 3.00$

NTIS

-Pages Selling Price

001-025 $\$ 4.00$

026-050 $\$ 4.50$

$051-075 \quad \$ 5.25$

076-100 \$6.00

$101-125 \quad \$ 6.50$

$126-150 \quad \$ 7.25$

151-175 $\$ 8.00$

$176-200 \quad \$ 9.00$

201-225 $\quad \$ 9.25$

226-250 $\$ 9.50$

251-275 $\$ 10.75$

$276-300 \quad \$ 11.00$ 
PNL -3153

UC -70

\section{9}

COMPARATIVE TECHNIQUES FOR NUCLEAR

FUEL CYCLE WASTE MANAGEMENT SYSTEMS

P. J. Pelto

J. W. Voss

September 1979

Prepared for

the U.S. Department of Energy

under Contract EY-76-C-06-1830

Pacific Northwest Laboratory

Richland, Washington 99352 
Recipients of PNL-3753

Dear Recipients:

RE: Comparative Techniques for Nuclear Fuel Cycle Waste Management Systems, Pacific Northwest Laboratory, Richland, WA. September 1979.

Please make the following changes in your copy of the subject report:

Page 5-26 - Table 5.23 values for the as-treated off gas should read:

$$
\frac{A}{9.2 \times 10^{-4}} \frac{\mathrm{TI}}{6.0 \times 10^{8}} \frac{\mathrm{GP}}{6.0 \times 10^{6}} \frac{\mathrm{HG}}{6.8 \times 10^{-6}} \frac{\mathrm{LL} \%}{56}
$$

Page 5-30 - Lines 3 and 4 shquld read: $A=9.2 \times 10^{-4} \mathrm{Ci}$,

$$
T_{I}=6.0 \times 10^{8} \mathrm{~m}^{3} \text { air, } L L=56 \%
$$

Page 5-33 - Table 5.29 values for the MOX plant routine effluents should read:

$$
9.2 \times 10^{-4}\left(6.0 \times 10^{8}\right)
$$

Page 5-35 - Table 5.30 values for the MoX plant routine effluents should read:

$$
1.5 \times 10^{-2}\left(9.6 \times 10^{9}\right)
$$

Sincerely,

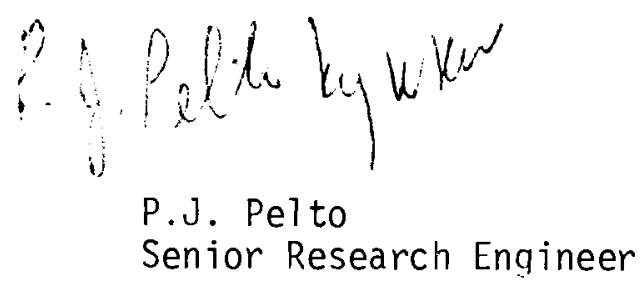




\section{CONTENTS}

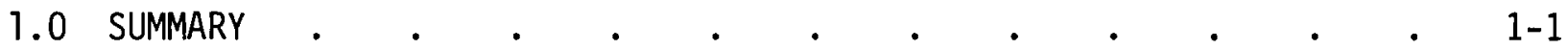

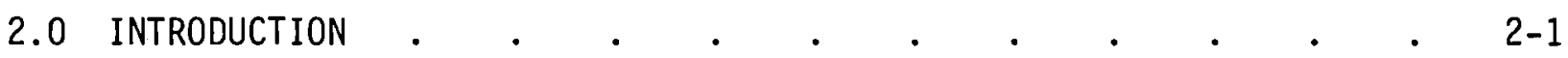

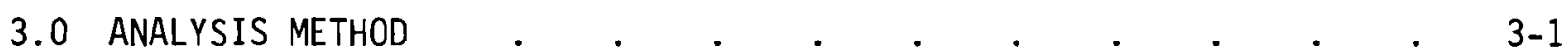

3.1 PRETREATMENT WASTE STREAMS . . . . . . . . . $3-3$

3.2 PROPOSED WASTE MANAGEMENT PROCESSES . • . . . . . 3-4

3.2.1 Routine Releases . . . . . . . . . . . 3-6

3.2.2 0ccupational Exposure . . . . . . . . .

3.2.3 Accidental Releases . . . . . . . . 3-7

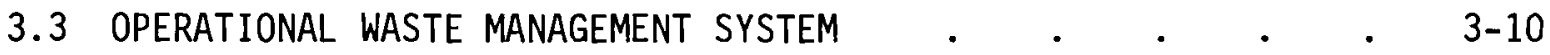

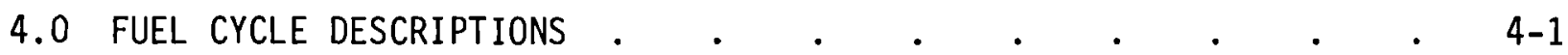

4.1 DESCRIPTION OF THE ONCE-THROUGH FUEL CYCLE — • • • • • 4-1

4.1.1 Description of the Reference Once-Through Fuel Cycle Facilities . . . . . . . . . . . 4-3

4.1.2 Description of the Once-Through Fuel Cycle Waste Streams . • . . . . . . . . . . 4 4-6

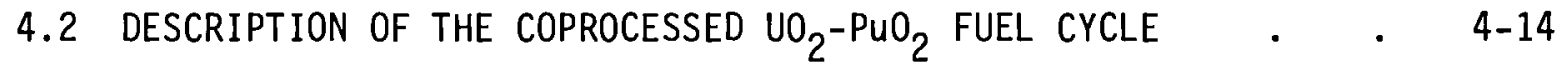

4.2.1 Description of the Reference Coprocessed $\mathrm{UO}_{2}-\mathrm{PuO}_{2}$
Fuel Cycle Facilities. . . . . $4-15$

\begin{tabular}{l} 
4.2.2 Description of the Coprocessed $\mathrm{UO}_{2}-\mathrm{PuO}_{2}$ Fuel Cycle \\
Waste Streams \\
\hline
\end{tabular}

5.0 INITIAL APPLICATION OF THE ANALYSIS APPROACH $\quad$ • . . $\quad$ 5-1

5.1 ANALYSIS OF THE ONCE-THROUGH FUEL CYCLE . . . . . . 5-1

5.1.1 Analysis of the Reference Reactor Waste Management Operations . . . . . . . . . . . . $5-1$

5.1.2 Analysis of the Reference Independent Spent Fuel
Storage Facil 
5.1.3 Analysis of the Reference Spent Fuel Packaging Facility Waste Management Operations . . . . . . 5-10

5.2 ANALYSIS OF THE COPROCESSED UO 2 FUEL CYCLE • • • • • 5-15

5.2.1 Analysis of the Reference Reactor Waste Management Operations . . . . . . . . . . 5-15

5.2.2 Analysis of the Fuel Coprocessing Facility Waste Management Operations . . . . . . . 5-15

5.2.3 Analysis of the Mixed Oxide Fuel Fabrication Facility Waste Management Operations . . . . . 5-25

5.3 COMPARISON OF THE ONCE-THROUGH AND COPROCESSED $\mathrm{UO}_{2}-\mathrm{PuO}_{2}$ FUEL 6.0 CONCLUSIONS AND RECOMMENDATIONS . . . . . . . . . . . 6-1 APPENDIX A - GENERAL SAFETY ASSESSMENT METHODS . . . • . . A A-1 APPENDIX B - DETAILED RADIONUCLIDE INVENTORIES FOR ONCE-THROUGH FUEL CYCLE WASTE STREAMS APPENDIX C - SYSTEM DEFINITION OF THE COPROCESSED $\mathrm{UO}_{2}-\mathrm{PuO}_{2}$ FUEL CYCLE . $\quad \mathrm{C}-1$ 


\section{FIGURES}

4.1 Once-Through Fuel Cycle . . . . . . . . . . . . . 4-2

4.2 Coprocessed $\mathrm{UO}_{2}-\mathrm{PuO}_{2}$ Fuel Cycle $\quad$.

4.3 Nuclear Power Plant Process Flow Diagram . . . . . . 4-4

4.4 Process Flow Diagram for Waste Basin Storage of Spent Fuel . 4-4

4.5 Major Process Functions of a Spent Fuel Packaging Facility . 4-7

4.6 Reference Reactor Radioactive Waste Treatment Systems . . . 4 4-7

4.7 Reference ISFSF Radioactive Waste Treatment Systems . . . 4-11

4.8 Reference Packaging Facility Radioactive Waste Treatment Systems 4-13

4.9 Simplified Schematic of the Fuel Reprocessing Plant Process . 4-16

4.10 Simplified Schematic of the Mixed Oxide Fuel Fabrication Plant

Process . . . . . . . . . . . . . . 4-17

4.11 Fuel Coprocessing Facility Radioactive Waste Management Strategy 4-20

4.12 Mixed Oxide Fuel Fabrication Facility Radioactive Waste Management Strategy . . . . . . . . . . . . . . 4-25

C. 1 Coprocessed $\mathrm{UO}_{2}-\mathrm{PuO}_{2}$ Fuel Cycle . . . . . . . . . . C-2

C. 2 Overall Flow Diagram for Conceptualized Coprocessing Facility . C-15

C.3 Spent Solvent Cleanup and HLW/LLW Concentration Flow Diagram for
Conceptualized Coprocessing Facility $. \quad . \quad . \quad . \quad . \quad . \quad C-16$

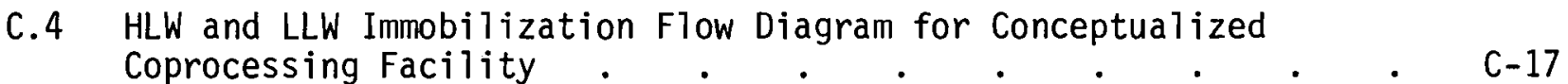

\begin{tabular}{lllll} 
C.5 Off-Gas System Flow Diagram for Conceptualized Coprocessing \\
Facility... \\
\hline
\end{tabular}

C.6 Off-Gas System for TRU Waste Incineration and Cementation . . C-33

C.7 Fuel Coprocessing Facility Radioactive Waste Management Strategy C-53

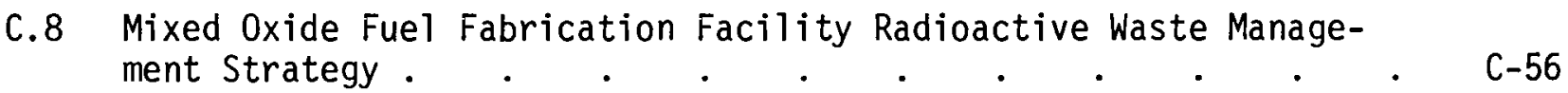


$\underline{\text { TABLES }}$

3.1 Hazardous Energy Sources . . . . . . . . 3-8

3.2 Generic List of Potential Accidents . . . . . . 3-9

4.1 Categorization of Once-Through Fuel Cycle Wastes According to Treatment Requirements. . . . . . . . 4-8

4.2 Reference Nuclear Power Plant Waste Streams . . . . . 4-8

4.3 Characteristics of Reactor As-Treated Radioactive Wastes . . 4-9

4.4 Reference ISFSF Waste Streams . . . . . . . 4-11

4.5 Characteristics of ISFSF As-Treated Radioactive Wastes . . 4-12

4.6 ISFSF Spent Fuel Characteristics . . . . . . . 4-12

4.7 Reference Spent Fuel Packaging Facility Waste Streams . . . 4-13

4.8 Characteristics of Packaging Facility As-Treated Radioactive Wastes 4-14

4.9 Packaging Facility Spent Fuel Characteristics . . . . 4-14

4.10 Pretreated Radioactive Wastes from a Fuel Coprocessing Facility - 4-19

4.11 Characterization of As-Treated Radioactive Wastes from the Fuel Coprocessing Facility . . . . . . . . . . . 4-19

4.12 Pretreated Radioactive Waste from a Mixed Oxide Fuel Fabrication Facility. . . . . . . . . . . . 4-25

4.13 Characterization of As-Treated Radioactive Wastes from the Mixed 0xide Fuel Fabrication Facility . . . . . . . 4-26

5.1 Safety Indices for Reactor Wastes . . . . . . . 5-2

5.2 Safety Indices for ISFSF Wastes . . . . . . . 5-4

5.3 Safety Indices for ISFSF Spent Fuel Operations . . . . 5-5

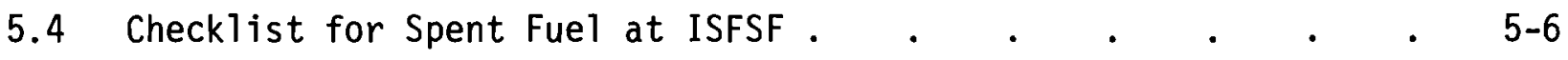

5.5 Checklist for Wet Waste Processing at ISFSF . . . . . 5-7

5.6 Postulated Accidents for Independent Spent Fuel Storage Facility 5-9 
5.7 Nuclear Waste Management Costs at an Independent Spent Fuel Storage Facility.

5.8 Safety Indices for Packaging Facility Wastes . . . . 5-11

5.9 Safety Indices for Packaging Facility Spent Fuel Operations . 5-12

5.10 Checklist for Spent Fuel Packaging . . . . . . 5-13

5.11 Postulated Accidents for Spent Fuel Packaging . . . . 5-13

5.12 Nuclear Waste Management Costs at a Spent Fuel Packaging Facility 5-14

5.13 Safety Indices for As-Generated and As-Treated Waste Streams at the Fuel Coprocessing Facility . . . . . . 5-16

5.14 Checklist for HLLW Storage . . . . . . . . 5-17

5.15 Checklist for HLLW Calcination/Vitrification . . . . 5-18

5.16 Checklist for HLLW Off-Gas System . . . . . . . 5-19

5.17 Checklist from SHLW Seal, Weld, Inspection and Decontamination - 5-20

5.18 Checklist for SHLW Onsite Water Basin Storage . . . . 5-21

5.19 Checklist for Hulls and Hardware Treatment . . . . . 5-22

5.20 Annual Effluent Characterization for Radioactive Waste Management at Fuel Coprocessing Plant . . . . . . . 5-23

5.21 Postulated Accidents for Coprocessing High-Level Liquid Waste Operations . . . . . . . . . 5-25

5.22 Nuclear Waste Management Costs of the Fuel Coprocessing Plant . 5-26

5.23 Safety Indices for As-Generated and As-Treated Waste Streams at the Mixed Oxide Fuel Fabrication Facility . . . . . 5-26

5.24 Checklist for Trash Incineration at the MOX Plant . . . 5-27

5.25 Checklist for HEPA Filter Packaging at the MOX Plant . . . 5-28

5.26 Checklist for wet Waste Cement Immobilization at the MOX Plant . 5-29

5.27 Potential Accidents for MOX Plant Trash Incineration Operations . 5-31

5.28 Nuclear Waste Management Costs at the MOX Fabrication Plant . 5-31 
5.29 Summary Table of Selected Characteristics of Once-Through and Coprocessing Fuel Cycle Facilities Waste Management Operations . 5-33

5.30 Summary Table for Once-Through and Coprocessing Fuel Cycle Waste Management Characteristics for a Hypothetical 200 Reactor Nuclear Economy .

B.1 Reactor Low Level Wastes

B.2 Reference ISFSF Low Level Wastes . . . . . . . B-2

B.3 Spent Fuel Packaging Facility Low Level Wastes . . . . B-3

B.4 Definition of Activation and Fission Products for Once-Through Low Level Wastes

B.5 Reference Nuclear Power Plant Off Gas . . . . . . B-5

B.6 Reference ISFSF Off Gas . . . . . . . . . . B-6

B.7 Reference Packaging Facility Off Gas . . . . . . . . B-7

B.8 Activation Product Inventory in Reference Fuel Assembly Hardware, as a Function of Decay Time, Once-Through Fuel Cycle . . . B-8

B.9 Activation Product Inventory in Reference Zircaloy Cladding Hulls as a Function of Decay Time, Once-Through Fuel Cycle. . . B-9

B.10 Fission Products in Reference Spent Fuel as a Function of Decay Time, Once-Through Fuel Cycle . . . . . . . B-10

B.11 Actinides and Daughters in Reference Spent Fuel as a Function of Decay Time, Once-Through Fuel Cycle . . . . . . B-12

C.1 Input Data to Burnup and Separations Calculations Using Origen - C-3

C.2 Heavy Metal Radionuclides In Spent, Coprocessed Fuel . . . C-4

C.3 Fission Product Radionuclides In Spent, Coprocessed Fuel . . C-5

C.4 Hulls and Hardware Radionuclides In Spent, Coprocessed Fuel . C-6

C.5 Fuel Cycle Facility Sizes and Inventories . . . . . C-8

C.6 Radionuclides in Wastes Generated in Receiving Spent Fuel at the Coprocessing Plant. . . . . . . . . . C-9

C.7 Primary Wastes from Coprocessing Radionuclide Content, Fraction of Spent Fuel Inventory 
C.8 Nonradiolytic Components, Coprocessing Gaseous Wastes . . . C-26

C.9 Off-Gas System Performance Specifications . . . . . C-31

C.10 Gaseous Waste from Coprocessing Plant . . . . . . C-37

C.11 Hulls and Assembly Hardware from Coprocessing Plant . . . C-39

C.12 High-Level Liquid Waste from Coprocessing Plant . . . . C-40

C.13 Concentrated Liquids, Wet Wastes, and Particulate Solids from Coprocessing Plant . . . . . . . . . . C C-41

C.14 Intermediate-Level Compactable Trash and Combustible Waste from Coprocessing Plant . . . . . . . . . . C-44

C.15 Low-Level Compactable Trash and Combustible Waste from Coprocessing Plant . . . . . . . . . . C C 46

C.16 Transuranic Failed Equipment and Noncompactable, Noncombustible Trash from Coprocessing Plant . . . . . . . C-47

C.17 Nontransuranic Failed Equipment and Noncompactable, Noncombustible Waste from Coprocessing Plant . . . . . . . C-48

C.18 Gaseous Waste from the Mixed Oxide Fuel Fabrication Plant . . C-49

C.19 Compactable Trash and Combustible Waste from the Mixed Oxide Fuel Fabrication Plant . . . . . . . . . . C-50

C.20 Concentrated Liquids, Wet Wastes, and Particulate Solids from the Mixed Oxide Fuel Fabrication Plant . . . . . .

C.21 Failed Equipment and Noncompactable, Noncombustible Waste from the Mixed Oxide Fuel Fabrication Plant . . . . . . C-52 
a 


\subsection{SUMMARY}

A safety assessment approach for the evaluation of predisposal waste management systems is described and applied to selected facilities in the light water reactor (LWR) once-through fuel cycle and a potential coprocessed $\mathrm{UO}_{2}-\mathrm{PuO}_{2}$ fuel cycle. This approach includes a scoping analysis on pretreatment waste streams and a more detailed analysis on proposed waste management processes. The primary evaluation parameters used in this study include radiation exposures to the public from radionuclide releases from normal operations and potential accidents, occupational radiation exposure from normal operations, and capital and operating costs.

The initial scoping analysis defines safety indices for the pretreatment waste streams based on such factors as radioactivity, volume, gamma power, heat generation, mobility, and toxicity. These indices can provide useful insights on relative comparisons of waste streams within a fuel cycle and of different cycles.

The more detailed analysis considers the waste streams in conjunction with their conceptual management systems. A preliminary checklist approach is suggested to identify and quantify safety areas of interest. These include processing conditions and inventories, required manpower, degree of containment, intermediate waste-form characteristics, degree of remote handling, and radionuclide effluents. For well-characterized waste management systems, quantitative information can be obtained. For some waste management systems, qualitative values can provide useful information. Using the above information, the public radiation dose and the occupational radiation exposures are estimated directly from the waste process details, or relative safety indices are established. A combination of a preliminary hazards analysis, along with a generic list of potential accidents, is used to assist in the quantification of the radiation exposure to the public from potential accidents. Capital and operating costs are estimated using the best available data.

The initial application to the once-through and coprocessed $\mathrm{UO}_{2}-\mathrm{PuO}_{2}$ fuel cycle waste management operations demonstrates the methodology, provides relative comparisons, and identifies information required for a more comprehensive analysis. 
On an overall basis, the waste management aspects of the two fuel cycles examined are quite similar. On an individual facility basis, the fuel coprocessing plant has the largest waste management impact. As one would expect, the important waste streams on a safety and cost basis are the spent fuel for the once-through fuel cycle and the solidified high-level waste for the coprocessed $\mathrm{UO}_{2}-\mathrm{PuO}_{2}$ fuel cycle.

As alternative fuel cycles are proposed, the approach suggested in this report may provide a ranking of the fuel cycle waste streams and useful comparisons between various fuel cycles. This information can be used to direct safety research and development on a time and cost effective basis. 


\subsection{INTRODUCTION}

The present nuclear weapons non-proliferation policy in the United States has resulted in a reevaluation of nuclear fuel cycle concepts. The choice of a nuclear fuel cycle involves considerations of many important economic, safety, and environmental considerations. Some considerations presently being examined in Department of Energy (DOE) research and development programs include non-proliferation characteristics and uranium resource utilization. Radioactive waste management is another consideration of importance.

As various alternative nuclear fuel cycles are suggested, their waste streams and proposed treatment processes need to be evaluated on a safety and cost basis to: 1) identify the important waste streams, 2) identify areas where safety design emphasis can be applied cost effectively, and 3) specify research and development needs. The objective of this study is to develop and demonstrate an analysis approach to perform these evaluations. This work was performed as a part of the Waste Management Safety Studies Program sponsored by the Department of Energy.

This report describes a method for evaluating predisposal waste management systems for alternative nuclear fuel cycles. The initial application of this analysis approach to the once-through fuel cycle and a potential coprocessed $\mathrm{UO}_{2}-\mathrm{PuO}_{2}$ fuel cycle is reported. The purpose of this initial analysis is to demonstrate the approach, provide relative comparisons between the once-through and the coprocessed fuel cycle waste management operations, and identify information required for a more comprehensive analysis.

The scope of the report is 1 imited to management of the post-fission waste produced by the once-through and coprocessing fuel cycles. Final disposal and transportation operations are not considered. Section 3.0 describes the analysis approach used, and Section 4.0 describes the reference fuel cycle waste management operations. The results of the initial analysis are given in Section 5.0. 
The Department of Energy has recently completed the Draft Environmental Impact Statement for the Management of Commercially Generated Radioactive Waste. ${ }^{(2)}$ This EIS and its supporting documents ${ }^{(3)}$ provided much of the information on the once-through fuel cycle facility descriptions and waste quantities used in this report.

\section{REFERENCES}

1. U.S. Department of Energy, Division of Nuclear Research and Applications, Nuclear Energy Assessments, Nonproliferation Alternative Systems Assessment Program: Final Program Plan for Management Review. September 15, 1977.

2. U.S. Department of Energy, Draft Environmental Impact Statement, Management of Commercially Generated Radioactive Waste. DOE/EIS-0046-D, Apri1 1979.

3. U.S. Department of Energy, Technology for Commercial Radioactive Waste Management. DOE/ET-0028, May 1979. 


\subsection{ANALYSIS METHOD}

As discussed in the introduction, the objective of this study is to develop and demonstrate a method to evaluate alternative nuclear fuel cycle waste management systems on the basis of safety and cost. The method should provide a ranking of the fuel cycle waste streams and useful comparisons with existing fuel cycles.

The primary evaluation parameters used in the study include radiation exposure to the public from radionuclide releases from normal operations and potential accidents, occupational radiation exposure from normal operations, and capital and operating costs. The evaluation of these areas is a potentially complex process. Various degrees of sophistication of method and output are possible. Safety techniques ranging from a preliminary hazards analysis to a detailed risk assessment may provide useful information depending upon the objectives and constraints of the safety analysis program. Appendix A provides a review of general safety assessment methods and gives simple examples of their use.

A waste management system can be analyzed in three stages: 1) pretreatment waste streams, 2) proposed waste management processes, and 3) operational waste management system. Safety and cost information are required for each of these stages of development. The quality and detail of existing information on the system design and performance influence the type of assessment method used. To be time and cost effective, the analysis approach should establish a priority ranking within each stage of development. For example, the analysis of the pretreatment waste streams should identify candidate waste streams for more detailed evaluations.

The approach selected for this study is formulated for the three stages of development of a waste management system. This approach includes a scoping analysis on the pretreatment waste streams and a more detailed analysis on the proposed waste management processes and operational waste management system. 
The first analysis stage examines the pretreatment waste streams. A series of simple indices based upon such factors as radioactivity, volume, gamma power, heat generation, mobility, and toxicity are defined and quantified for each waste stream. These indices can provide useful insights on relative comparisons of waste streams within a fuel cycle and of different fuel cycles.

The second analysis stage examines the waste streams in conjunction with the proposed waste management processes. A preliminary checklist approach is suggested to identify and quantify safety areas of interest. These include processing conditions and inventories, required manpower, degree of containment, intermediate waste form characteristics, degree of remote handling, and radionuclide effluents. For well-characterized waste management systems, quantitative information can be obtained. For some waste management systems, qualitative values can provide useful information. Using this information, the public radiation dose and the occupational radiation exposures are either estimated directly from the waste process details or relative safety indices are established. A combination of a preliminary hazards analysis, along with a generic list of potential accidents is used to assist in the quantification of the radiation exposure to the public from potential accidents. Capital and operating costs are estimated using the best available data.

More sophisticated assessment methods such as a detailed risk assessment can be productively applied to a waste management process as its life cycle enters the detailed design and operational stages. The waste management systems under study are not currently at this stage of development.

The analysis approach selected for this study is outlined in detail in the following sections. The discussion is divided into three sections corresponding to the stages of development of a waste management system. 


\subsection{PRETREATMENT WASTE STREAMS}

A logical starting point in the safety analysis is to assemble all available information on the pretreatment waste streams for the fuel cycle under study. The following indices are defined for each waste stream:

1. Volume of waste (V)

2. Mass of waste (M)

3. Activity of waste (A)

4. Toxicity index (TI) (based on MPC in water and in air)

5. Gamma power (GP) (a)

6. Heat generation ( $H G)$

7. Mobility index (MI) (e.g., nonleachable solid $=10^{-6}$, liquid $=10^{-3}$, gas $=1$ )

8. Available technology index (AT) (e.g., similar waste has been processed $=0$, unique processing required $=10$ )

9. Percent long-lived nuclides (LL) ${ }^{(b)}$

It is anticipated that the above indices can crudely rank the waste streams on the basis of safety emphasis required (both public and occupational) and potential treatment cost. Once the radionuclide inventories are known, much of the required information can be obtained from the computer program ORIGEN ${ }^{(1)}$.

Using the once-through fuel cycle as an example, the following format is proposed to facilitate waste stream comparisons and ranking:

(a)This index is intended primarily for potential occupational exposure. A more sophisticated index based on energy release rates and photon reiease rates may be required.

(b)A possible form of this index is \% TRU nuclides or \% decay after $t$ years, where $t$ is a particular time of interest. 


\begin{tabular}{|c|c|c|c|c|c|c|c|c|c|}
\hline Waste Stream & V & $M$ & $A$ & TI & GP & HS & MI & AT & $\mathrm{LL}$ \\
\hline Reactor trash & & & & & & & & & \\
\hline Noble gases & & & & & & & & & \\
\hline Spent fue 1 & & & & & & & & & \\
\hline Packaging tras & & & & & & & & & \\
\hline $\begin{array}{c}\text { Interim storag } \\
\text { wet waste } \\
\cdot \\
\cdot \\
\text { etc. }\end{array}$ & & & & & & & & & \\
\hline
\end{tabular}

The above format can be used to rank the waste streams within a fuel cycle on a priority basis. More detailed analyses can be performed on the waste streams that "stand out" (have several relatively high safety indices). For fuel cycles that are not well characterized, a preliminary comparison between fuel cycles can be made using the above format for each fuel cycle.

It is recognized that use of these indices does not provide the final answer. For a complete safety analysis, the waste streams must be considered in conjunction with their management systems. However, it is believed that useful insights can be obtained on relative comparisons of waste streams within a fuel cycle, and for some cases of different fuel cycles.

\subsection{PROPOSED WASTE MANAGEMENT PROCESSES}

The next step in the safety analysis is to perform more detailed analyses on the waste streams and their management systems. For each waste stream, all available information on the proposed processing and management schemes is assembled. The four primary areas of interest are: 
1. radiation exposure to the public from releases from normal operations,

2. radiation exposure to the public from potential accidents,

3. occupational radiation exposure, and

4. capital and operating costs.

As a first step, a checklist approach is suggested. For each waste process, the following general checklist is defined:

- Processing Temperature

- Processing Pressure

- Processing Chemicals

- Number of Treatment Steps

- Number of Handling Steps

- Degree of Remote Processing and Handling

- Intermediate Waste Form and Characteristics(a)

- Energy Input Required and Number of High Energy Sources

- Degree of Concentration of Nuclides (largest radionuclide inventory in one vessel)

- Final Waste Form and Characteristics(a)

- Manpower Required

- Degree of Maintenance Required

- Processing Time Required

- Estimated Radionuclide Effluents

- Number of Barriers Between Waste and Environment

- Estimated Occupationar Dose

- Estimated Cost

(a)For final and intermediate waste forms, apply waste stream indices as previously described. 
For waste management systems that are conceptually well characterized, quantitative information can be placed in the checklist. Occupational dose and radioactive effluents from normal operations can be estimated directly. For waste management systems for which little data are available, the table can be filled in with qualitative values (high, medium, low) and useful information for comparing alternatives may still be obtained.

Using this information, the following approaches are proposed to evaluate routine releases, occupational exposure, and accidental releases.

\subsubsection{Routine Releases}

For well-characterized waste management systems, the public radiation exposure from normal operations can be estimated directly from radionuclide release estimates. A dose calculation for a one-year period to an individual at a specified distance under assumed meteorological conditions and living habits seems appropriate for comparative purposes. A basic assumption is that the airborne pathway is dominant. A crude relative comparison can be made using the toxicity index for each effluent stream.

Relative safety indices for public radiation exposure from normal operations can be established for waste management systems that are not well characterized. Using the information from the checklist, an index combining inventory, process time, handling steps, number of barriers, and intermediate waste form characteristics would be appropriate. A simple index consisting of the product of the toxicity index and the mobility index divided by one hundred to the power of the number of containment barriers is proposed for initial use. This index is derived from the arbitrary assumption of a DF of 100 for a typical containment barrier.

\subsubsection{Occupational Exposure}

As is true for routine releases, the occupational radiation exposures can be estimated directly for well-characterized waste management systems. Occupational dose calculations for a one-year period for the total estimated manpower involved in the waste management system of interest would be appropriate. Operating and maintenance procedures combined with estimated radiation 
levels provide the basic input data. Estimates of occupational radiation exposure are very sensitive to the management philosophy and the operating procedures utilized.

A relative safety index for occupational radiation exposure would include such checklist factors as inventory, manpower, processing time, degree of remote processing, degree of maintenance, and intermediate waste-form characteristics. A simple index consisting of the product of the gamma power and the manpower divided by the degree of remote processing is proposed for initial use.

\subsubsection{Accidental Releases}

The initial checklist also provides useful information when considering potential accidents. Waste management processes with high pressures, high temperatures, and large inventories of concentrated radionuclides certainly merit careful examination. Numerous safety analysis techniques can be applied to a waste management system to obtain information on potential accidents (see Appendix A). A suggested approach is given below.

A list of hazardous elements as shown in Table $3.1^{(2)}$ is defined. For each waste process, the hazardous elements are identified. The primary use of this information is an input for a preliminary hazards analys is (PHA).

A next step is to prepare a simple process-oriented preliminary hazards analysis (i.e., consider mainly the process initiated accidents). Following this analysis, a generic list of potential accidents is applied to each waste process, and the probability of occurrence and the consequences are estimated. The accidents included in this list should represent a wide spectrum in probability of occurrence and resulting consequences. The contents of this list should be based on previous operating experience and on past risk/safety analyses. Table 3.2 gives some accidents which may be included in such a list. Any unique, highly process specific accident identified in the PHA should be analyzed. Since each waste process may have different radionuclide inventories, some sort of dose calculation is required. The safety analyses are primarily 
TABLE 3.1. Hazardous Energy Sources ${ }^{(2)}$

1. Fuels

2. Propellants

3. Initiators

4. Explosive charges

5. Charged electrical capacitors

6. Storage batteries

7. Static electrical charges

8. Pressure containers

9. Spring-loaded devices

10. Suspension systems
11. Gas generators

12. Electrical generators

13. $r f$ energy sources

14. Radioactive energy sources

15. Falling objects

16. Catapulted objects

17. Heating devices

18. Pumps, blowers, fans

19. Rotating machinery

20. Actuating devices

21. Nuclear devices, etc.

\section{Hazardous Processes and Events}

1. Acceleration

2. Contamination

3. Corrosion

4. Chemical dissociation

5. Electrical shock therma 1 inadvertent activation power source failure electromagnetic radiation

6. Explosion

7. Fire

8. Heat and temperature high temperature low temperature temperature variations

9. Leakage
10. Moisture high humidity low humidity

11. Oxidation

12. Pressure high pressure low pressure rapid pressure changes

13. Radiation thermal electromagnetic ionizing ultraviolet

14. Chemical replacement

15. Mechanical shock, etc. 
TABLE 3.2. Generic List of Potential Accidents

\author{
Handling Errors \\ Process Incidents - \\ Transfer Error \\ Ventilation System Failure \\ Loss of Cooling \\ Explosion \\ Fire \\ Criticality \\ Natural Events - \\ Tornado \\ Earthquake \\ Flood \\ Sabotage \\ Aircraft Crash
}

to compare alternatives so a dose calculation to an individual at a specific distance under assumed meteorological conditions seems appropriate $(e . g ., 1 \mathrm{~km}$, type $\mathrm{F}$ stability, $1 \mathrm{~m} / \mathrm{sec}$ wind speed). A basic assumption is that the airborne pathway is dominant. A crude relative comparison can be made using the toxicity index for the accidental release.

A final step which may be useful is an approach similar to that used by McGrath ${ }^{(3)}$. A reference level of risk is defined (e.g., $30 \mathrm{mrem} /$ year to individual). For each waste process, the highest physically possible release is postulated (e.g., 100\% of the volatiles in the radionuclide inventory). This release is assumed to occur, and the accident probability required to meet the reference level of risk is calculated. These probabilities are compared for each waste process. An equivalent approach is to compare directly the maximum release for each waste process. 
A combination of the above analyses can provide a useful mechanism for relative comparisons of potential accidental releases from conceptual waste management processes.

\subsection{OPERATIONAL WASTE MANAGEMENT SYSTEM}

As a proposed waste management process moves from the conceptual to the detailed design to the operational state, more sophisticated safety methods can be applied. Once the system details are well defined, detailed safety assessment methods can provide input for designing and licensing a waste management system. Once the waste management system is operational, detailed safety methods can be used to improve the system. Areas of interest include establishing efficient operating and maintenance procedures, improving the system and subsystem reliability, and upgrading the general safety of the waste management system. A detailed risk analysis can provide valuable input to the above areas.

\section{REFERENCES}

1. M. J. Be11, ORIGEN - The ORNL Isotope Generation and Depletion Code. ORNL-4628, Oak Ridge National Laboratory, Oak Ridge, TN, May 1973.

2. H. E. Lambert, Fault Trees for Decision Making in Systems Analysis. UCRL-51829, Lawrence Livermore Laboratory, October 1975.

3. P. E. McGrath, Radioactive Waste Management Potentials and Hazards from a Risk Point of View. KFK-1922, 1974. 


\subsection{FUEL CYCLE DESCRIPTIONS}

The two basic nuclear fuel cycle options that are considered in this report are the LWR once-through cycle and a potential LWR coprocessed $\mathrm{UO}_{2}{ }^{-}$ $\mathrm{PuO}_{2}$ fuel cycle.

In the reference once-through fuel cycle, irradiated fuel assemblies are stored in water-cooled storage basins (either at the nuclear power plant or at an offsite independent spent fuel storage facility), followed by packaging and final isolation in a geologic repository.

In the selected coprocessed $\mathrm{UO}_{2}-\mathrm{PuO}_{2}$ fuel cycle, irradiated fuel assemblies are stored in water-cooled storage basins at the reactor and the coprocessing plant, followed by coprocessing to recover the residual uranium and plutonium in the spent fuel. During coprocessing, uranium and plutonium are separated and purified using the Purex solvent extraction process. In the separations process, only part of the uranium, fission products, and other actinides are separated from the plutonium. A pure plutonium stream does not exist. The uranium is converted to $\mathrm{UF}_{6}$ and returned to the enrichment plant. The plutonium stream is converted into a $\mathrm{UO}_{2}-\mathrm{PuO}_{2}$ powder, contaminated with fission products and actinides. This $\mathrm{UO}_{2}-\mathrm{PuO}_{2}$ powder is shipped to a mixed-oxide fuel fabrication plant where it is fabricated into fuel elements.

Figures 4.1 and 4.2 provide an overall schematic of the once-through and coprocessing post fission operations. These operations are discussed in more detail in the following sections. The low level waste burial ground and the geologic repository are outside the scope of the study.

\subsection{DESCRIPTION OF THE ONCE-THROUGH FUEL CYCLE}

As shown in Figure 4.1, the post fission facilities in the reference once-through fuel cycle include a pressurized water reactor (PWR), an independent spent fuel storage basin, and a spent fuel packaging facility. As discussed in Section 2.0, the low level waste burial ground, the geologic 


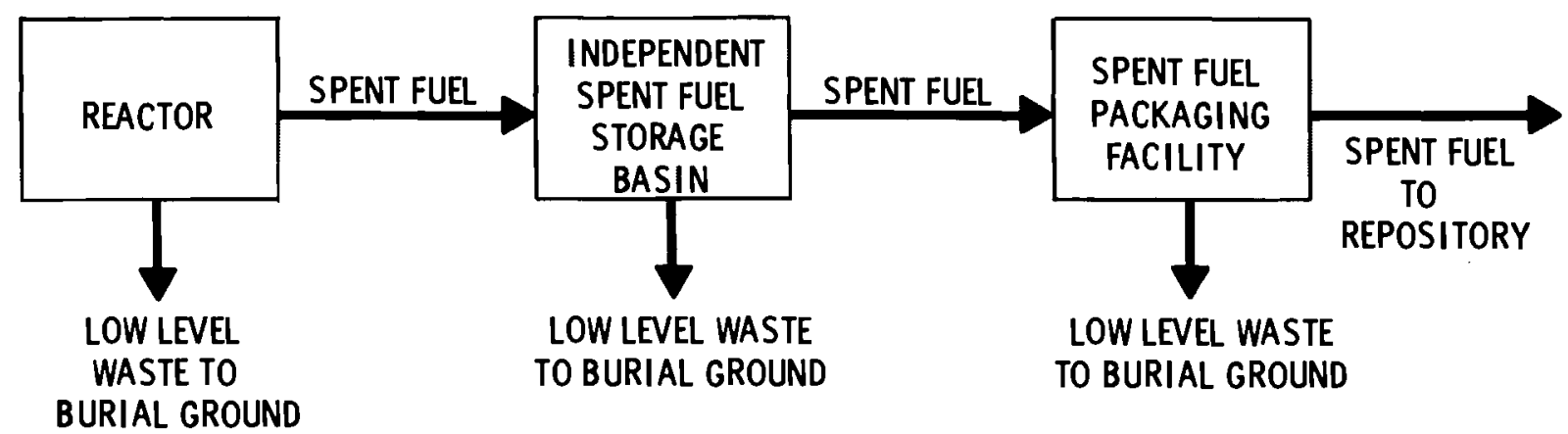

FIGURE 4.1. Once-Through Fuel Cycle

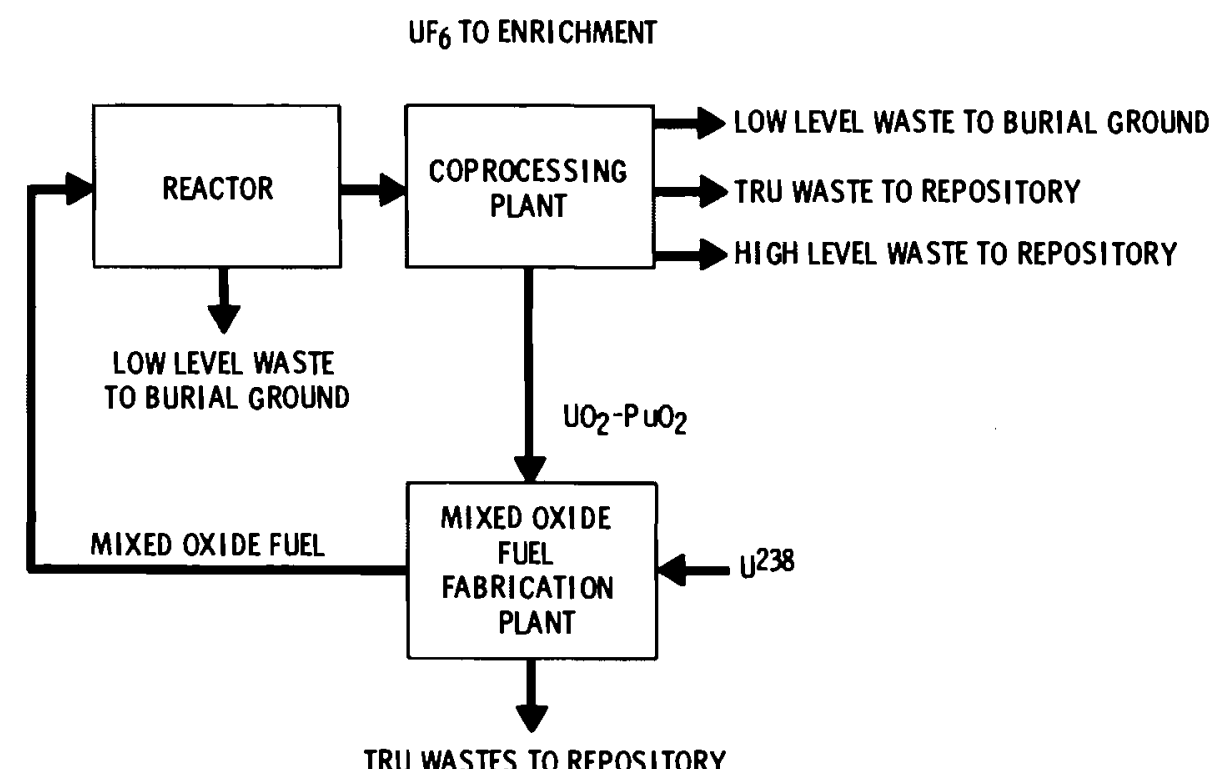

TRU WASTES TO REPOSITORY

FIGURE 4.2. Coprocessed $\mathrm{UO}_{2}-\mathrm{PuO}_{2}$ Fuel Cycle 
repository, and the transportation operations are not considered in this study. The reference facility system descriptions are based on material given in DOE/ET-0028. (1)

\subsubsection{Description of the Reference Once-Through Fuel Cycle Facilities}

This section provides brief system descriptions for each of the oncethrough fuel cycle facilities.

\subsubsection{Description of the Reference Nuclear Power Plant}

The reference nuclear power plant for this report is a PWR capable of generating 1200 MWe. Figure 4.3 gives a process flow diagram for the reference reactor. The reactor core contains the $\mathrm{UO}_{2}$ fuel assemblies. The coolant system circulates water to transfer heat generated in the core to steam generators where steam is produced to operate the turbines and generate electricity. The chemical and volume control system maintains and controls the coolant system water inventory and water chemistry. A spent fuel storage area receives the fuel from the reactor core and stores it for at least six months. The liquid radioactive waste treatment system receives wastes from various parts of the reactor including primary water storage overflow, fuel storage pool overflow, and various drains and sumps. The off-gas collection system consists of a gas collection system and a vent system. The gaseous effluents are filtered and monitored prior to release. Additional details of the nuclear power plant system description are provided in reference 1 .

\subsubsection{Description of the Reference Independent Spent Fuel Storage Basin}

The reference independent fuel storage basin consists of six water-filtered pools, each with a storage capacity of 500 MTHM. Figure 4.4 gives the process flow diagram for the reference independent fuel storage facility (ISFSF). A packaging facility is assumed to be adjacent to the ISFSF. As described in reference 1 , the facility is assumed to receive 6-month-old fuel from reactor storage pools at an average rate of $500 \mathrm{MTHM} / \mathrm{yr}$ for six years. Fuel that has been at the facility for 6 years is transferred to the packaging facility at an average of $500 \mathrm{MTHM} / \mathrm{yr}$ and replaced with 6-month-0ld fuel from the reactor storage pools. Fuel that has been cooled elsewhere for 6.5 years is received 


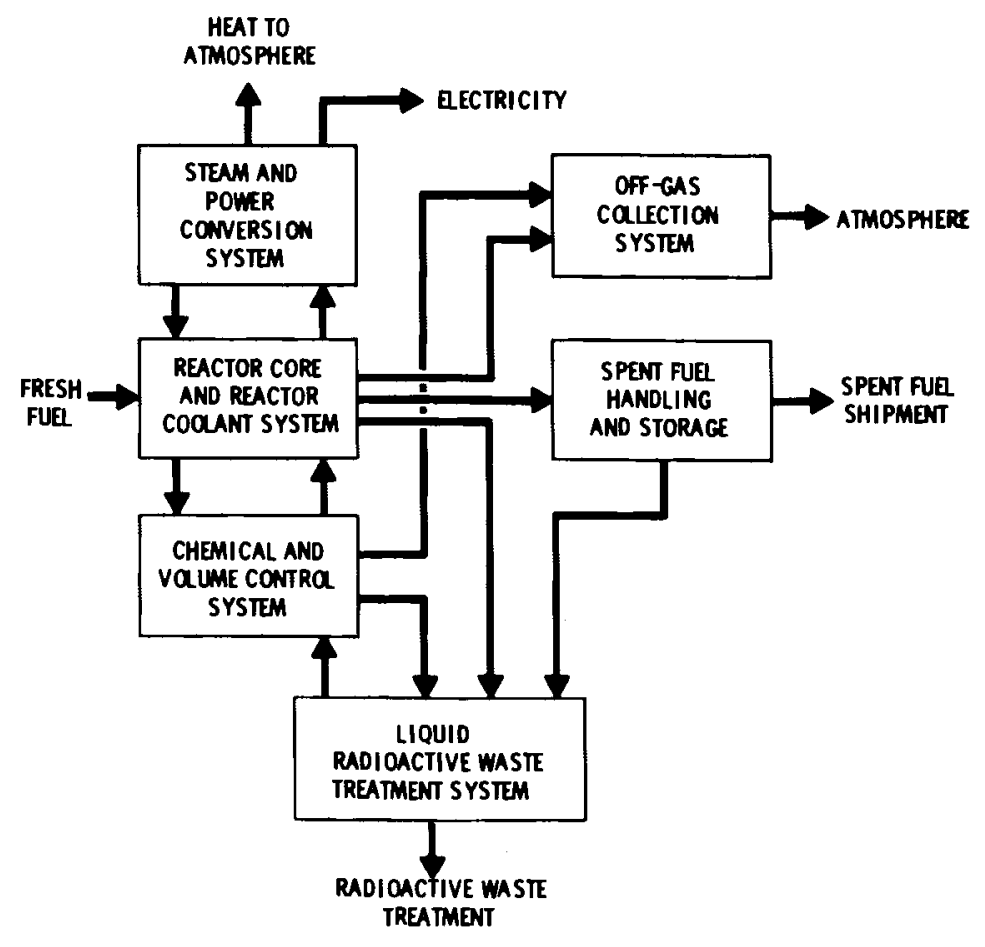

FIGURE 4.3. Nuclear Power Plant Process Flow Diagram (1)

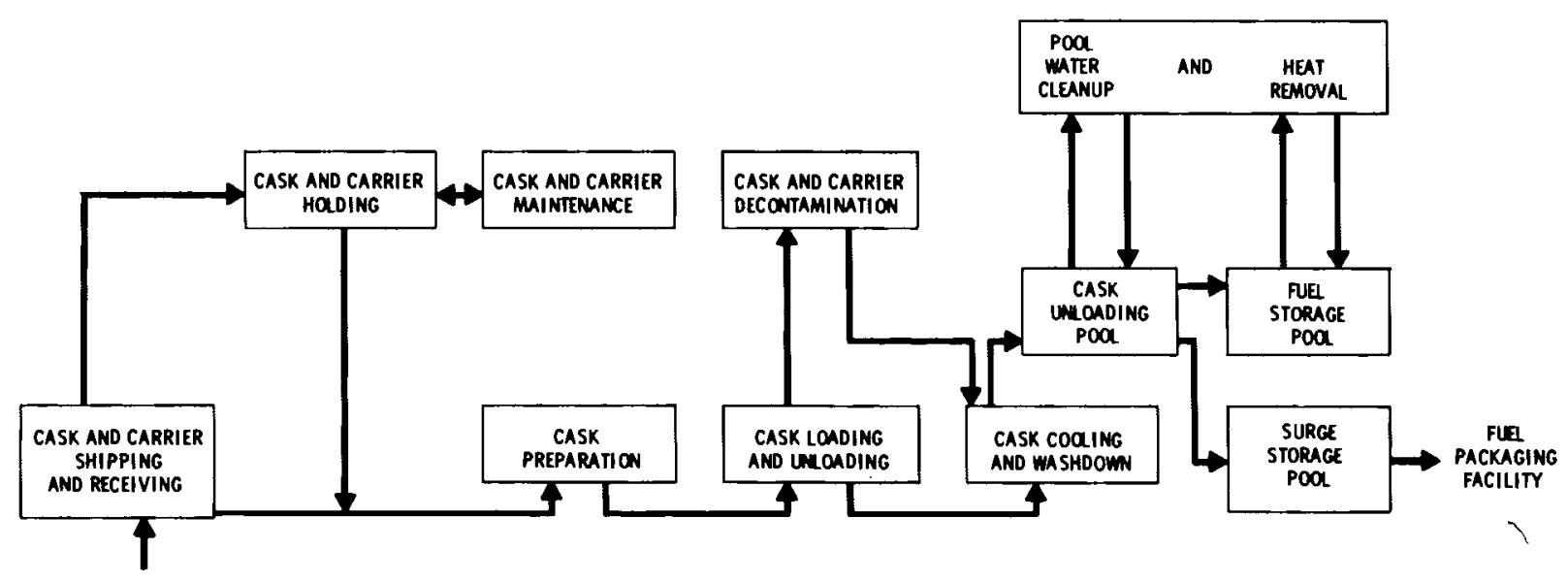

FIGURE 4.4. Process Flow Diagram for Water Basin Storage of Spent Fuel (1) 
at an average of 1500 MTHM/yr and routed directly to the packaging facility. The maximum heat generated by the stored fuel is 12 MW with a maximum heat load per basin of $5 \mathrm{MW}$.

Irradiated fuel assemblies are received in shielded shipping casks transported by truck or rail. The casks and transport vehicles are monitored and inspected for shipping damage. A normal cask-carrier is transferred to the preparation area where peripheral equipment is removed. Damaged casks are sent to the holding area and are repaired in the maintenance area. The casks are separated from the carrier and monitored in the cask loading and unloading area. A normal cask is transferred to the cooling and washdown area. A contaminated cask is sent to the cask decontamination pit. After cask washdown, the cask is vented and cooled if required in the cooling and washdown area. The cask is placed in the cask unloading pool by the cask transfer crane and the 1 id is removed. The fuel assemblies are removed and those with leaks are placed in a special container. Assemblies, which are not leaking, are placed in storage baskets which are transferred to the storage basin.

The storage pools provide cooling and shielding for the spent fuel. The fuel baskets are placed into racks fastened to the pool floor. The pool water is circulated in a closed primary system to a heat exchanger outside the pool where heat is transferred to a secondary system. The basin water does not leave the storage area building. The secondary water circulation system removes heat from a heat exchanger and discharges it to the atmosphere via a cooling tower. The pool water cleanup system employs a filter-deionizer system capable of maintaining normal pool water activity at less than $2.4 \times 10^{-4} \mathrm{Ci} / \mathrm{m}^{3}$ and rapidly reducing the activity level in any pool due to a release from leaking fuel. Additional details of the independent fuel storage facility are provided in reference 1 .

\subsubsection{Description of the Reference Spent Fuel Packaging Facility}

The reference spent fuel packaging facility packages its fuel elements in steel containers after the initial 6.5 year storage period at reactor storage pools, offsite ISFSFs, or the adjacent ISFSF. The steel containers provide additional containment for extended storage or shipment to a final repository. The packaging facility is assumed to be adjacent to an ISFSF. 
Figure 4.5 gives the process flow diagram for the reference spent fuel packaging facility. Empty canisters are received from offsite, inspected, and stored in the canister receiving and storage area. Each fuel element is individually packaged in a canister. Failed fuel elements also require an overpack. Spent fuel assemblies are moved into the drying and canister loading cell from the adjacent ISFSF through water canals. The assemblies are placed in floor wells and dried and monitored. Any failed fuel is transferred to the failed fuel packaging area. The fuel assemblies are packaged into the canisters, top plates are welded on, air is evacuated, and helium is added. The canisters are sealed and moved to the holding and testing area where they are monitored for a two-day period for helium and fission product release. The packaged spent fuel is then transferred to the offsite loading area where it is loaded into a shipping cask and placed onto the rail car or truck. Additional details of the spent fuel packaging facility are provided in reference 1 .

\subsubsection{Description of the Once-Through Fuel Cycle Waste Streams}

Radioactive wastes are generated in each of the reference facilities of the once-through fuel cycle. The spent fuel is classed as a waste in this fuel cycle. Table $4.1^{(1)}$ provides general waste categories and treatment requirements for the once-through fuel cycle. The pretreatment waste streams and the treatment methods are summarized in this section for each reference facility. Reference 1 was the primary source for much of this information.

\subsubsection{Nuclear Power Plant Wastes}

The wastes generated in a light water reactor will vary in type and quantity depending upon such factors as reactor type, size and age of the reactor, and operating philosophy. Primary sources of reactor wastes include water cleanup, air cleaning operations, and plant maintenance operations. Table 4.2 gives the waste volume and radioactivity for the reference nuclear power plant. Information on the specified radionuclide content is given in Appendix B. Figure 4.6 provides the reference treatment systems and Table 4.3 gives the as-treated waste characteristics. Each type of waste and its treatment systems are briefly discussed in the following paragraphs. 


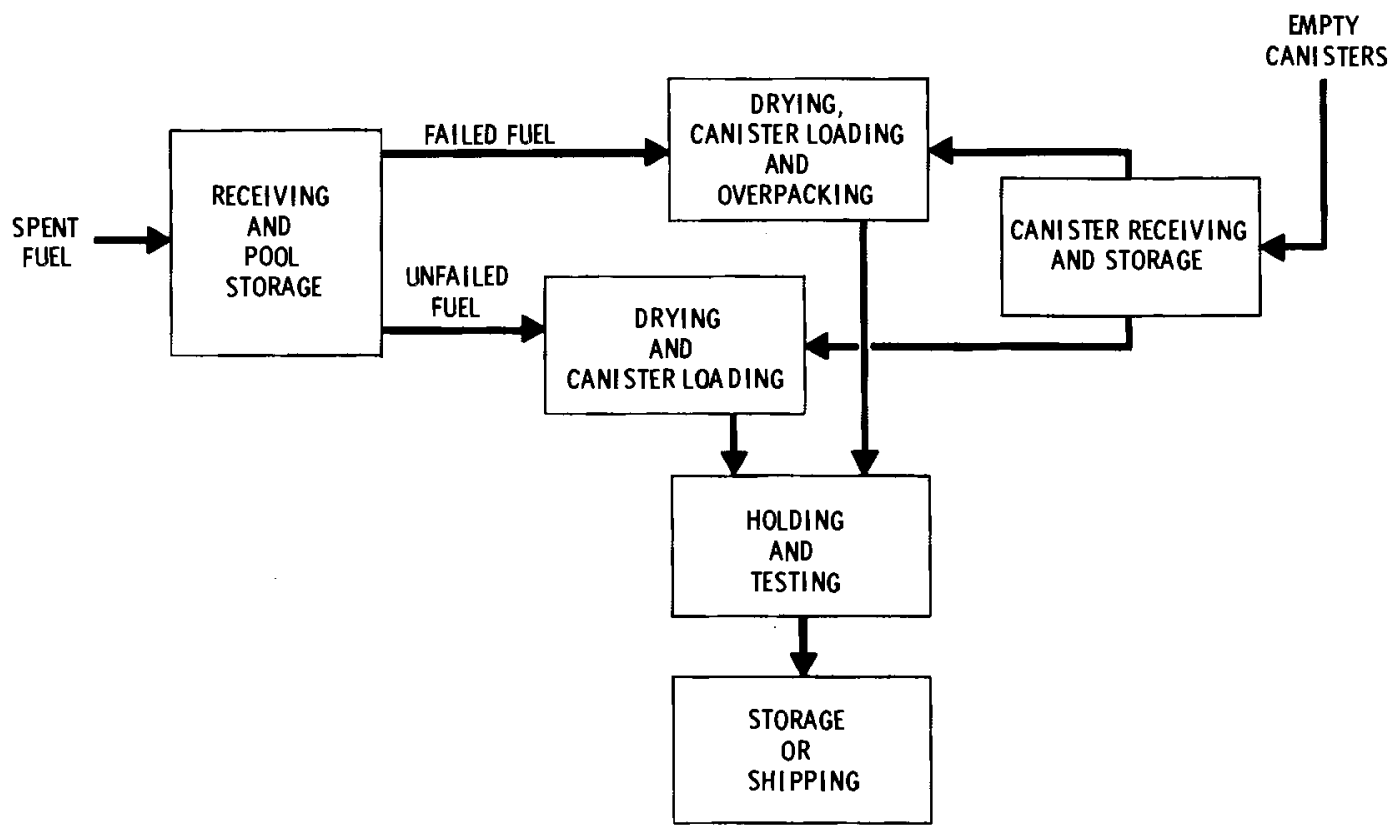

FIGURE 4.5. Major Process Functions of a Spent Fuel Packaging Facility (1)

TABLE 4.1. Categorization of Once-Through Fuel Cycle Wastes According to Treatment Requirements

Waste Category
Gaseous
Compactable trash and
combustible wastes
Concentrated liquids,
wet wastes, and par-
ticulate solids
Failed equipment and
noncompactable, non-
combustible wastes

Spent fuel assemblies
Treatment Requirements

Reduce activity to approved levels by removing particulate and volatile radioisotopes.

Reduce volume. Reduce combustion hazard. Package in approved container for shipment and disposal.

Convert to approved solid form.

Package in approved container for shipment and disposal.

Reduce activity level by decontamination. Reduce volume by dismantlement, cutting, etc. Package in approved container for shipment and disposal.

Package in approved container for interim storage and disposal. 
TABLE 4.2. Reference Nuclear Power Plant Waste Streams

As Generated Volume Radioactivity Waste Type $\left(\mathrm{m}^{3} / \mathrm{yr}\right)$

( $\mathrm{C} / \mathrm{yr}$ )

Compactable and

combustible waste

$170^{(a)}$

12

Wet wastes

300

$4.5 \times 10^{3}$

Noncombustible trash

34

1

Off gas

$1.5 \times 10^{10}$

$1.3 \times 10^{4}$

Spent fue1

13

$1.1 \times 10^{8}$

(a) Included are approximately $4-m^{3}$ HEPA filters

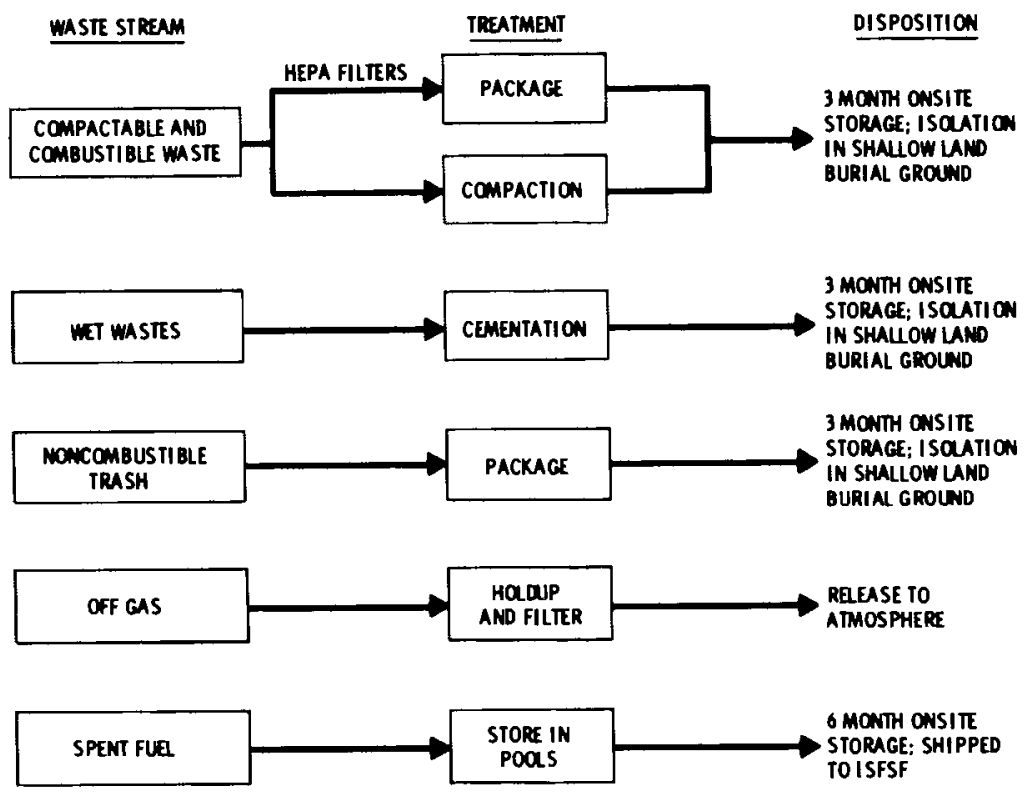

FIGURE 4.6. Reference Reactor Radioactive Waste Treatment Sys tems 
TABLE 4.3. Characteristics of Reactor As-Treated Radioactive Wastes

\begin{tabular}{|c|c|c|c|c|}
\hline Waste Type & $\begin{array}{l}\text { Treated } \\
\text { Volume } \\
\left(\mathrm{m}^{3} / \mathrm{yr}\right)\end{array}$ & Container Type & $\begin{array}{c}\text { Number of Containers/ } \\
\text { plant year } \\
\end{array}$ & $\begin{array}{l}\text { Radioactivity } \\
\text { container } \\
\text { (Ci) }\end{array}$ \\
\hline $\begin{array}{l}\text { Compactable and } \\
\text { combustible } \\
\text { non-filters } \\
\text { filters }\end{array}$ & $\begin{array}{l}42 \\
4.2\end{array}$ & $\begin{array}{l}\text { 55-gal. drum }\left(0.21 \mathrm{~m}^{3}\right) \\
80 \text {-gal. drum }\left(0.31 \mathrm{~m}^{3}\right)\end{array}$ & $\begin{array}{r}200 \\
14\end{array}$ & $\begin{array}{l}0.06 \\
0.06\end{array}$ \\
\hline Wet wastes & 480 & 55-gal. drum $\left(0.21 \mathrm{~m}^{3}\right)$ & 2290 & 2 \\
\hline $\begin{array}{l}\text { Noncombustible } \\
\text { trash }\end{array}$ & 36 & 55-gal. $\operatorname{drum}\left(0.21 \mathrm{~m}^{3}\right)$ & 171 & 0.01 \\
\hline Off gas & $N / A$ & $N / A$ & $N / A$ & $N / A$ \\
\hline Spent fue 1 & 13 & fuel assembly & 61 & $1.8 \times 10^{6}$ \\
\hline
\end{tabular}

- Compactable and Combustible Wastes. Compactable and combustible wastes from a nuclear power plant include high-efficiency particulate air (HEPA) filters and the combustible trash from cleanup of leaks, servicing of the cooling system, and analytical operations. HEPA filters are packaged in 80-galion drums without treatment. The combustible trash is compacted and packaged in 55-gallon drums. Reference 2 provides additional details on these operations.

- Wet Wastes. Reactor wet wastes result from the water cleanup operations. These include ion exchange, filtration, and volume reduction by evaporization. Types of wastes include powdered and bead resins, filter cartridges and sludges. Wet wastes are immobilized in cement using a drum tumbling system. Wet wastes are packaged in 55-gallon drums. Reference 2 provides additional details on these operations.

- Noncombustible Waste. Noncombustible waste is also generated from cleanup operations, cooling system services and analytical operations. Failed plant equipment is also in this category but is not considered in this study. Data 
on its properties, quantities and disposition are not available. (2) Large pieces of failed reactor equipment could potentially have a high radionuclide content. The noncombustible trash is disassembled if necessary and packaged in 55-gallon drums. Reference 2 provides additional details on this operation.

- Spent Fuel. Spent fuel is classified as a waste in the once-through fuel cycle. The spent fuel assemblies are stored in the reactor storage basins and assumed to be shipped to an independent spent fuel storage basin after six months.

- Gaseous. Volatile fission products and particulate solids are released from fuel cladding failure and treated by the gaseous radioactive waste system. This system consists of decay tanks, adsorbers and filters. The treated gas stream is released to the environment.

\subsubsection{Independent Spent Fuel Storage Wastes}

Table 4.4 gives the waste volume and radioactivity for the reference spent fuel storage facility. The primary sources of the waste are similar to those of the reference reactor, i.e., water cleanup, air cleaning and plant maintenance. Information on the specific radionuclide content of the waste streams is given in Appendix B. Figure 4.7 provides the reference treatment systems and Table 4.5 gives the as-treated waste characteristics. Spent fuel is a waste in the once-through fuel cycle. Table 4.6 lists the quantities and the radioactivity levels of the spent fuel received, stored and transferred in the ISFSF. Details on the specific radionuclide content are provided in Appendix $B$.

\subsubsection{Spent Fuel Packaging Facility Wastes}

Table 4.7 gives the waste volume and radioactivity for the reference spent fuel packaging facility. The primary sources of waste are similar to those of the independent fuel storage facility. Information on the specific radionuclide content is given in Appendix B. Figure 4.8 provides reference treatment systems 
TABLE 4.4. Reference ISFSF Waste Streams

\begin{tabular}{|c|c|c|}
\hline Waste Type & $\begin{array}{c}\text { As Generated Volume } \\
(\mathrm{m} 3 / \mathrm{yr})\end{array}$ & $\begin{array}{l}\text { Radioactivity } \\
\quad(\mathrm{Ci} / \mathrm{yr})\end{array}$ \\
\hline $\begin{array}{l}\text { Compactable and } \\
\text { combustible waste }\end{array}$ & 1500 & 24 \\
\hline Wet wastes & 60 & 3500 \\
\hline $\begin{array}{l}\text { Noncombustible } \\
\text { waste and failed } \\
\text { equipment }\end{array}$ & 150 & 2.3 \\
\hline Off gas & $4.0 \times 10^{9}$ & 890 \\
\hline
\end{tabular}

(a) Included are approximately $36-m^{3}$ ventilation filters
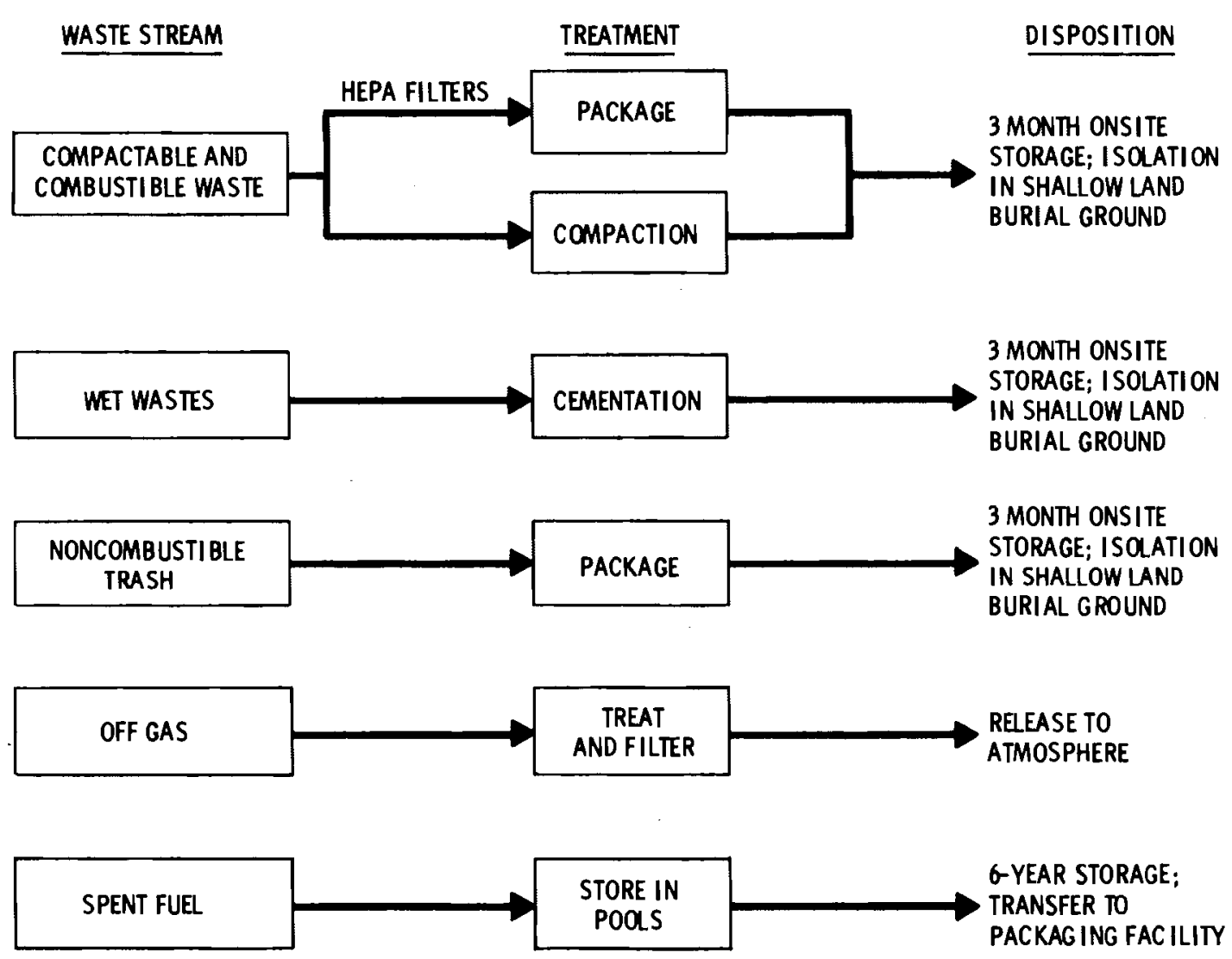

FIGURE 4.7. Reference ISFSF Radioactive Waste Treatment Systems 


\section{TABLE 4.5. Characteristics of ISFSF As-Treated Radioactive Wastes}

\begin{tabular}{|c|c|c|c|c|}
\hline Waste Type & $\begin{array}{l}\text { Treated } \\
\text { Volume } \\
\left(\mathrm{m}^{3} / \mathrm{yr}\right)\end{array}$ & Container Type & $\begin{array}{l}\text { Number of Containers/ } \\
\text { plant year }\end{array}$ & $\begin{array}{l}\text { Radioactivity } \\
\text { container } \\
\text { (Ci) }\end{array}$ \\
\hline $\begin{array}{l}\text { Compactable and } \\
\text { combustible waste } \\
\text { non-filters } \\
\text { filters }\end{array}$ & $\begin{array}{r}366 \\
38\end{array}$ & $\begin{array}{l}55-\text { gal. drum }\left(0.21 \mathrm{~m}^{3}\right) \\
80 \text { gal. drum }\left(0.31 \mathrm{~m}^{3}\right)\end{array}$ & $\begin{array}{r}1740 \\
123\end{array}$ & $\begin{array}{l}0.01 \\
0.01\end{array}$ \\
\hline Wet wastes & 96 & 55-gal. drum $\left(0.21 \mathrm{~m}^{3}\right)$ & 457 & 8 \\
\hline $\begin{array}{l}\text { Noncombustible } \\
\text { trash }\end{array}$ & 158 & 55-gal. $\operatorname{drum}\left(0.21 \mathrm{~m}^{3}\right)$ & 752 & 0.003 \\
\hline Off gas & $N / A$ & $\mathrm{~N} / \mathrm{A}$ & N/A & $\mathrm{N} / \mathrm{A}$ \\
\hline
\end{tabular}

\section{TABLE 4.6. ISFSF Spent Fuel Characteristics}

\begin{tabular}{lcccc}
\multicolumn{1}{c}{ Operation } & MTHM Spent Fuel & Number of Fuel Assemblies (a) & Radioactivity (Ci) \\
\cline { 1 - 1 } Receiving (per year) & $2000^{(b)}$ & & 4348 & $2.4 \times 10^{9}$ \\
Storage & $3000^{(b)}$ & 6522 & $2.1 \times 10^{9}$ \\
Transfer (per year) & $2000^{(b)}$ & 4348 & $8.9 \times 10^{8}$
\end{tabular}

\footnotetext{
(a) Number of assemblies calculated for PWR fuel (0.46 MTHM per assembly).

(b) 500 MTHM per year of 0.5 year old spent fuel received for storage; 1500 MTHM per year of 6.5-year old spent fuel received for transfer to adjacent packaging facility; 500 MTHM per year of 6.5-year old spent fuel transferred from ISFSF to packaging facility; inventory of ISFSF 3000 MTHM of spent fuel at an average age of 3.5 years.
} 
TABLE 4.7. Reference Spent Fuel Packaging Facility Waste Streams

\begin{tabular}{lcc}
\multicolumn{1}{c}{ Waste Type } & $\begin{array}{c}\text { As Generated Volume } \\
\left(\mathrm{m}^{3} / \mathrm{yr}\right)\end{array}$ & $\begin{array}{c}\text { Radioactivity } \\
(\mathrm{C} i / \mathrm{yr})\end{array}$ \\
\cline { 1 - 2 } $\begin{array}{l}\text { Combustible and } \\
\text { Compactable } \\
\text { waste }\end{array}$ & $550^{(\mathrm{a})}$ & 1 \\
$\begin{array}{l}\text { Wet wastes } \\
\begin{array}{l}\text { Noncombustible } \\
\text { waste and } \\
\text { failed equipment }\end{array}\end{array}$ & 20 & 910 \\
Off gas & 60 & 0.1 \\
\end{tabular}

(a) Included are approximately $14-\mathrm{m}^{3}$ ventilation filters
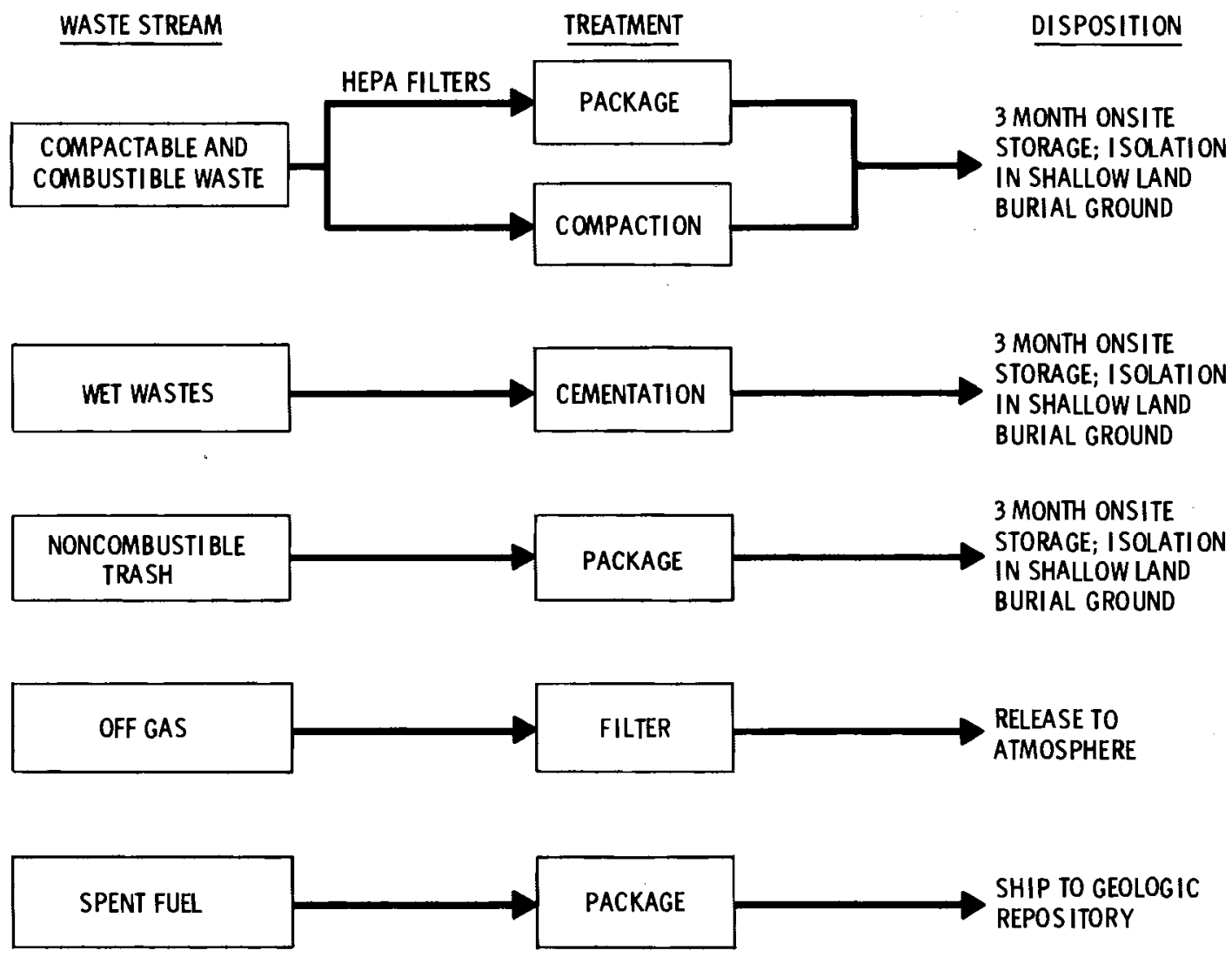

FIGURE 4.8. Reference Packaging Facility Radioactive Waste Treatment Systems 
and Table 4.8 gives the as-treated waste characteristics. Spent fuel is a waste in the once-through fuel cycle. Table 4.9 lists the quantities and the radioactivity levels of the spent fuel received, stored, packaged and shipped from the packaging facility. Details on the specific radionuclide content is provided in Appendix B.

TABLE 4.8. Characteristics of Packaging Facility As-Treated Radioactive Wastes

\begin{tabular}{|c|c|c|c|c|}
\hline Waste Type & $\begin{array}{l}\text { Treated } \\
\text { Volume } \\
\left(\mathrm{m}^{3} / \mathrm{yr}\right)\end{array}$ & Container Type & $\begin{array}{c}\text { Number of Containers/ } \\
\text { plant year }\end{array}$ & $\begin{array}{c}\text { Radioactivity/ } \\
\text { container } \\
\text { (Ci) }\end{array}$ \\
\hline $\begin{array}{l}\text { Compactable and } \\
\text { combustible waste } \\
\text { non-filters } \\
\text { filters }\end{array}$ & $\begin{array}{r}134 \\
14.7\end{array}$ & $\begin{array}{l}55 \text {-gal. drum }\left(0.21 \mathrm{~m}^{3}\right) \\
80 \text {-gal. } \operatorname{drum}\left(0.31 \mathrm{~m}^{3}\right)\end{array}$ & $\begin{array}{r}638 \\
47\end{array}$ & $\begin{array}{l}0.001 \\
0.001\end{array}$ \\
\hline Wet wastes & 32 & 55 -gal. drum $\left(0.21 \mathrm{~m}^{3}\right)$ & 152 & 6 \\
\hline $\begin{array}{l}\text { Noncombustible } \\
\text { trash }\end{array}$ & 63 & $55-g a 1 . \operatorname{drum}\left(0.21 \mathrm{~m}^{3}\right)$ & 300 & 0.0003 \\
\hline Off gas & N/A & $N / A$ & N/A & $N / A$ \\
\hline
\end{tabular}

TABLE 4.9. Packaging Facility Spent Fuel Characteristics

\begin{tabular}{lcccc}
\multicolumn{1}{c}{ Operation } & MTHM Spent Fuel & Number of Fuel Assemblies (a) & Radioactivity Ci \\
\cline { 1 - 1 } Receiving (per year) & 2000 & 50 & 4348 & $8.9 \times 10^{8}$ \\
Surge storage & 2000 & 1087 & $2.2 \times 10^{7}$ \\
Packaging \& shipping (b) & & & 4348 & $8.9 \times 10^{8}$
\end{tabular}

(a) Number of assemblies calculated for PWR fuel (0.46 MTHM per assembly).

(b) Fuel assemblies are individually packaged.

\subsection{DESCRIPTION OF THE COPROCESSED UO $2-{ }_{2}{ }_{2}{ }_{2}$ FUEL CYCLE}

As shown in Figure 4.2, the post fission facilities in the reference coprocessed $\mathrm{UO}_{2}-\mathrm{PuO}_{2}$ fuel cycle include a pressurized water reactor (PWR), a coprocessing plant and a mixed oxide fuel fabrication plant. As discussed in Section 2.0, the low-level waste burial ground, the geologic repository and the transportation operations are not considered in this study. The reference coprocessing scheme used in this study is detailed in Appendix $C$. 


\subsubsection{Description of the Reference Coprocessed $\mathrm{UO}_{2}-\mathrm{PuO}_{2}$ Fuel Cycle Facilities}

This section provides brief system descriptions for each of the coprocessed $\mathrm{UO}_{2}-\mathrm{PuO}_{2}$ fuel cycle facilities.

\subsubsection{Description of the Reference Nuclear Power Plant}

The nuclear power plant present in the coprocessed $\mathrm{UO}_{2}-\mathrm{PuO}_{2}$ fuel cycle is assumed to be identical to that of the once-through fuel cycle, for the purposes of this study. Details of the facility are presented in Section 4.1.1.1.

\subsubsection{Description of the Reference Coprocessing Facility}

The fuel coprocessing facility provides for the recovery of the uranium and plutonium contained in spent nuclear fuel. The fission product spiked $\mathrm{UO}_{2}-\mathrm{PuO}_{2}$ powder stream is recycled via a mixed-oxide fuel fabrication facility to a nuclear power plant. The $\mathrm{UF}_{6}$ product of the fuel coprocessing facility is recycled to the nuclear power plant following enrichment and fuel fabrication. Figure 4.9 gives a simplified process flow diagram for the reference coprocessing plant. The reference fuel coprocessing facility involves the following processing steps: ${ }^{(1)}$

- Underwater Storage of Spent Fuel Awaiting Processing. The storage capacity is about 2000 MTHM, the fuel is stored six months at the reactor water basin prior to receipt and the fuel is stored for one year before coprocessing. The typical fuel will have an average burnup of 29,000 MWD/MTHM.

- Co-recovery of the Uranium and Plutonium. Uranium and plutonium are recovered by solvent extraction using the PUREX process $(3,4,5)$ at a processing rate of 2000 MTHM/yr during 300 days of operation per year. The spent fuel elements are chopped into short sections so that the contained fuel can be dissolved in nitric acid. The mixture, uranium, plutonium and fission products, is separated utilizing a solvent, kerosene with tributyl phosphate, so that approximately $1 \%$ of the fission products remain mixed with the uranium and plutonium. Subsequently $90 \%$ of the uranium is separated, resulting in three output streams; unconcentrated high-level liquid wastes, the purified uranium product, and a fission product spiked U-Pu stream. 


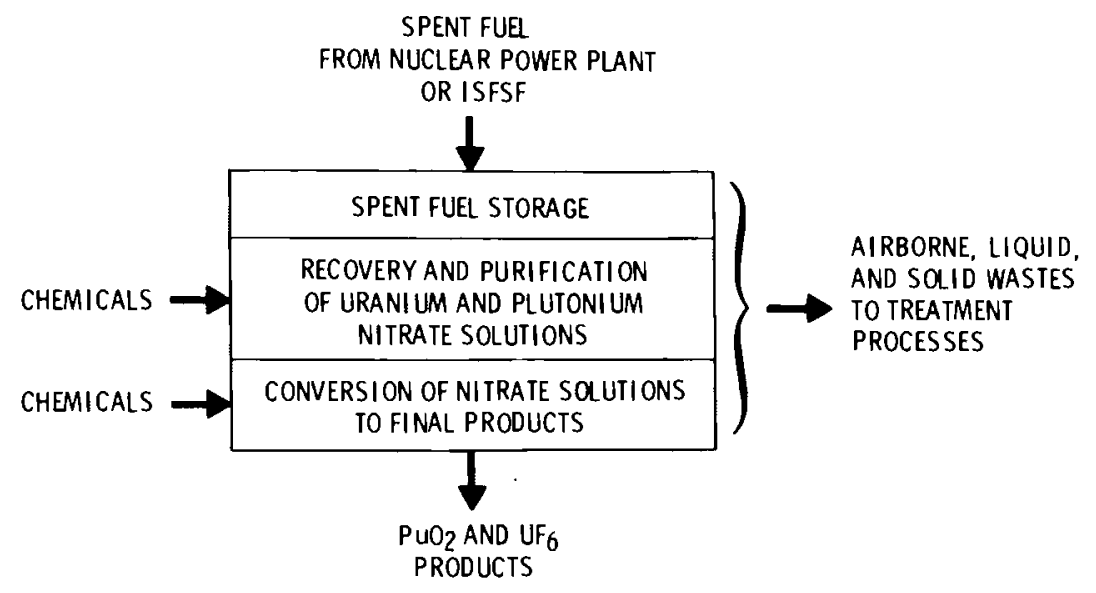

FIGURE 4.9. Simplified Schematic of the Fuel Reprocessing Plant Process(1)

- Conversion of Plutonium/Uranium Mixture to a Solid. The fission product spiked, uranium-plutonium stream is converted to a powder form. This is accomplished by calcining the aqueous stream, and subsequently reducing it, to convert the $\mathrm{UO}_{3}$ to $\mathrm{UO}_{2}$.

- Conversion of Uranium to $U_{6}$. The uranyl nitrate solution, following purification is calcined to form $\mathrm{UO}_{3}$, and reduced to form $\mathrm{UO}_{2} \cdot \mathrm{UO}_{2}$ is converted to $\mathrm{UF}_{3}$ using gaseous $\mathrm{HF}$, and the $\mathrm{UF}_{3}$ is converted to $\mathrm{UF}_{6}$ using elemental fluorine. (6)

4.2.1.3 Description of the Reference Mixed Oxide Fuel Fabrication Facility

A mixed oxide fuel fabrication facility prepares reactor fuel containing a mixture of the fission product spiked, $\mathrm{UO}_{2} / \mathrm{PuO}_{2}$ output from the coprocessing facility, and depleted uranium from an enrichment facility. Figure 4.10 gives a simplified process flow diagram for the reference mixed oxide fuel fabrication facility. The facility receives the $\mathrm{UO}_{2} / \mathrm{PuO}_{2}$ stream, depleted $\mathrm{UO}_{2}$ powder, Zircaloy tubes, and the assorted hardware constituting nuclear power plant fuel. The plant has the capacity to produce $400 \mathrm{MTHM} / \mathrm{yr}$ of mixed-oxide fuel during 300 days of operation. The typical fuel has $3.3 \%$ fissile enrichment, and about $5 \%$ of the heavy metal is plutonium. Because of the fission product spiking in the feed material, all operations in the facility must be remotely performed. The major process steps include the following: 


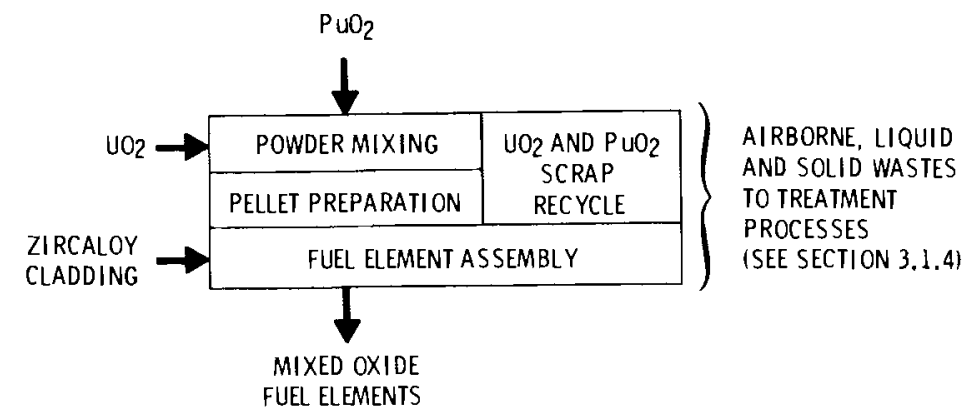

FIGURE 4.10. Simplified Schematic of the Mixed Oxide Fuel Fabrication Plant Process(1)

- mechanical mixing of fission product spiked, $\mathrm{UO}_{2} / \mathrm{PuO}_{2}$ powder and depleted $\mathrm{UO}_{2}$ powder;

- preparation of fuel pellets from the mixture by pressing, sintering and grinding;

- sealing the pellets within zircaloy cladding to form fuel pins;

- fabricating fuel bundles; and

- scrap recycle, preserving the denaturing and spiking of the plutonium.

\subsubsection{Description of the Coprocessed $\mathrm{UO}_{2}-\mathrm{PuO}_{2}$ Fuel Cycle Waste Streams}

Radioactive wastes are generated in each of the reference facilities and the coprocessed $\mathrm{UO}_{2}-\mathrm{PuO}_{2}$ fuel cycle. The pretreatment waste streams and the treatment methods are summarized for each facility in this section.

\subsubsection{Nuclear Power Plant Wastes}

A description of the radioactive wastes from a nuclear power plant is presented for the once-through fuel cycle in Section 4.1.2. In this study, it assumed that the radioactive wastes would be identical at a nuclear power plant for the coprocessed $\mathrm{UO}_{2}-\mathrm{PuO}_{2}$ fuel cycle. Slightly different volumes and radioactivities could be expected at a nuclear power plant using coprocessed $\mathrm{UO}_{2}-\mathrm{PuO}_{2}$ fuel. However, these differences are estimated to be slight and to have minimal impact on the results of this study. 


\subsubsection{Fuel Coprocessing Facility Wastes}

Table 4.10 lists overall waste volumes and radioactivities for the reference coprocessing facility. As discussed earlier, the plant receives 2000 MTHM/yr of spent fuel, stores that fuel for one year and coprocesses $2000 \mathrm{MTHM} / \mathrm{yr}$. The plant-year basis assumes full receiving, storage and processing capacity. Details about waste volumes and radioactivities are given in Appendix C. Figure 4.11 provides the reference treatment systems and Table 4.11 gives the as-treated waste characteristics. Each type of waste and its treatment system are briefly described in the following paragraphs.

- High-Level Liquid Wastes. The high-level liquid waste from the fuel coprocessing facility consists of the concentrated raffinate from the first extraction cycle, the dissolver sludge, the bottoms of the low-level concentrator, and a recycle condensate stream (see Appendix C). The high-level liquid waste contains about $95 \%$ of the fission product zirconium, niobium, ruthenium and rhodium, $0.2 \%$ of the uranium, $0.5 \%$ of the plutonium, and $99 \%$ of the other fission products and actinides.

High-level liquid waste is immobilized by calcination and vitrification with in-can melting. A surge tank system is provided to hold 15 plant-days of high-level liquid waste. The surge system consists of a 300 -gallon routing tank and three 10,000-gallon titanium tanks. All equipment is remote and located within hot cells, including the surge tanks (see Section 7.3.7 of Reference 5 for a comprehensive description of the surge tank system). The waste is immobilized in stainless steel canisters that are 12 inches in diameter and 10 feet long. Following immobilization, the canisters are stored for 5 years in an onsite water basin.

- Hulls and Hardware. The hulls and hardware are the zircaloy and stainless steel materials which formed rods and bundles. Prior to the dissolution, the spent nuclear fuel is sheared. Consequently, the hulls and hardware are in small pieces. The radioactivity in the hulls and hardware consists of neutron activation products, fission products and actinide contaminants. 
TABLE 4.10. Pretreated Radioactive Wastes from a Fuel Coprocessing Facility

Waste Type

High-Level Liquid

Hulls and Hardware

General Trash

Wet Waste

Scrap

Off Gas
Volume Radioactivity

(m3/plant-yr) (Ci/plant-yr)

1420

$3.3 \times 10^{9}$

640

$2.1 \times 10^{7}$

5000

$6.1 \times 10^{6}$

270

$8.0 \times 10^{3}$

1410

$6.4 \times 10^{9}$
$1.8 \times 10^{5}$

$1.6 \times 10^{7}$

TABLE 4.11. Characterization of As-Treated Radioactive Wastes from the Fuel Coprocessing Facility

\begin{tabular}{|c|c|c|c|c|c|}
\hline Waste Type & $\begin{array}{c}\text { Treated } \\
\text { Volume, } \\
\left(\mathrm{m}^{3} / \mathrm{plant-yr}\right)\end{array}$ & Container Type & $\begin{array}{l}\text { Number of } \\
\text { Containers/ } \\
\text { plant-yr }\end{array}$ & $\begin{array}{l}\text { Radioactivity/ } \\
\text { Container(a) (Ci) }\end{array}$ & $\begin{array}{l}\text { Post-Treatment } \\
\text { Disposition }\end{array}$ \\
\hline $\begin{array}{l}\text { Solidified high } \\
\text { level waste }\end{array}$ & 180 & $\begin{array}{l}12 \text { in. } x 10 \mathrm{ft} . \\
\text { canister, } 0.22 \mathrm{~m}^{3}\end{array}$ & 830 & $4.0 \times 10^{6}$ & $\begin{array}{l}\text { 5-year onsite storage } \\
\text { in water basin; isolation } \\
\text { in repository. }\end{array}$ \\
\hline $\begin{array}{l}\text { Hulls and } \\
\text { hardware }\end{array}$ & 670 & $\begin{array}{l}30 \mathrm{in} . \times 10 \mathrm{ft} \\
\text { canister } \\
1.39 \mathrm{~m}^{3}\end{array}$ & 480 & $4.4 \times 10^{4}$ & $\begin{array}{l}\text { 3-month onsite storage; } \\
\text { isolation in repository }\end{array}$ \\
\hline $\begin{array}{l}\text { General trash } \\
\text { non-filter } \\
\text { filters }\end{array}$ & $\begin{array}{l}890 \\
370\end{array}$ & $\begin{array}{l}\text { 55-gal. drums, } \\
0.21 \mathrm{~m}^{3} \\
80-g a 1 . \text { drums, } \\
0.31 \mathrm{~m}^{3}\end{array}$ & $\begin{array}{l}4,240 \\
1,190\end{array}$ & $\begin{array}{l}1.1 \times 10^{2} \\
4.7 \times 10^{3}\end{array}$ & $\begin{array}{l}\text { 3-month onsite storage; } \\
\text { isolation in shallow } \\
\text { land burial or repository, } \\
\text { as applicable. }\end{array}$ \\
\hline Wet waste & 430 & $\begin{array}{l}\text { 55-gal. drums, } \\
0.21 \mathrm{~m}^{3}\end{array}$ & 2,060 & 3.8 & $\begin{array}{l}\text { 3-month onsite storage; } \\
\text { isolation in shallow } \\
\text { land burial or repository, } \\
\text { as applicable. }\end{array}$ \\
\hline Scrap & 1500 & $\begin{array}{l}55-g a l \text { drums, } \\
0.21 \mathrm{~m}^{3}\end{array}$ & 7,100 & 25 & $\begin{array}{l}\text { 3-month onsite storage; } \\
\text { isolation in shallow land } \\
\text { burial or repository, as } \\
\text { applicable. }\end{array}$ \\
\hline Off gas & $N / A$ & $N / A$ & $N / A$ & $N / A$ & Treated and Released \\
\hline
\end{tabular}

(a) Average radioactivity per container at time of treatment 

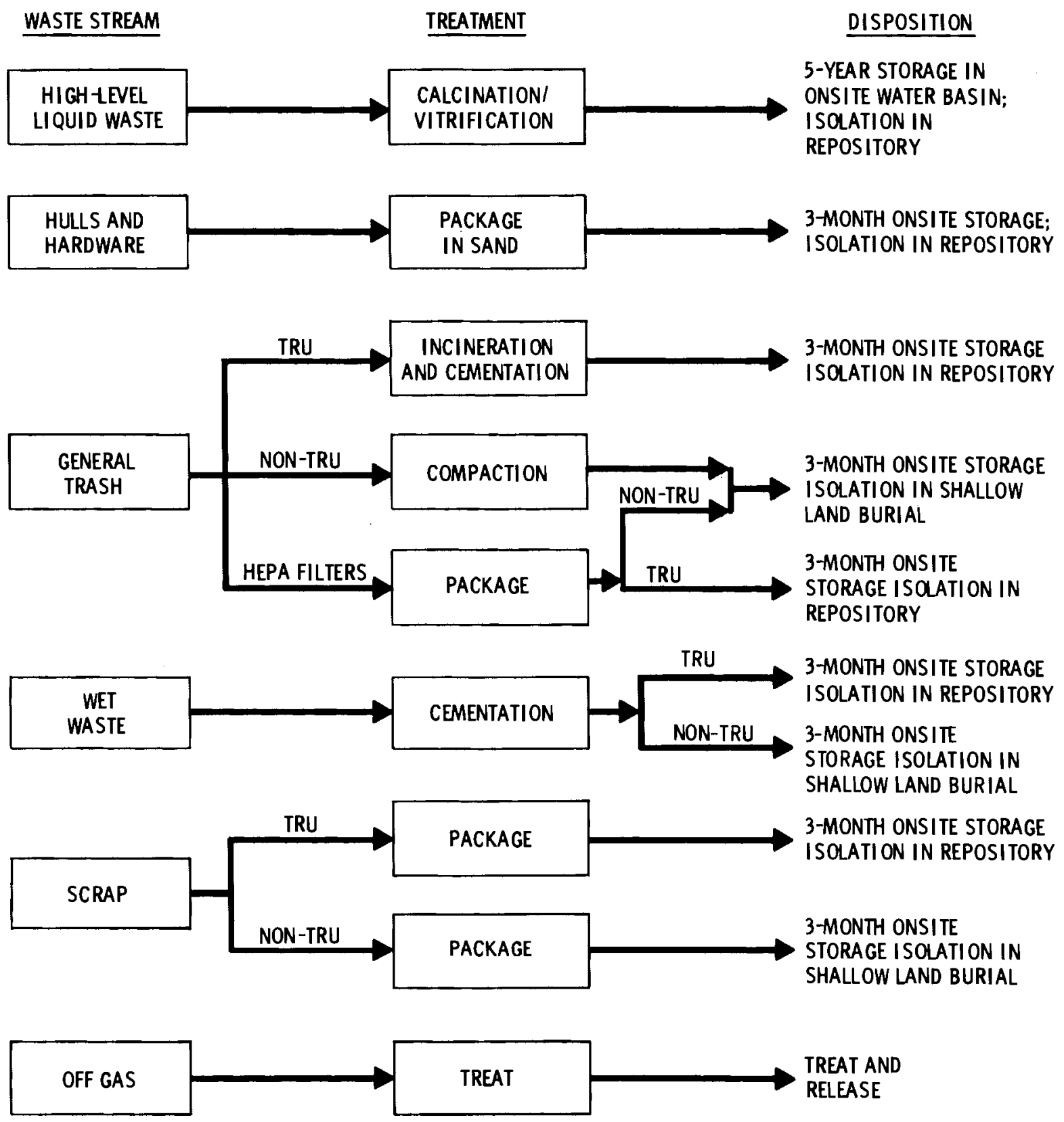

FIGURE 4.11. Fuel Coprocessing Facility Radioactive Waste Management Strategy 
Hulls and hardware are packaged in carbon steel containers with sand as a filling matrix. The process is selected because of its simplicity, and because other alternatives are not as developed. The process is totally remote. Waste containers are 30 inches in diameter and 10 feet long.

- General Trash. The fuel coprocessing facility general trash is divided into five categories. One group is designated as intermediate-level transuranic (TRU), where intermediate level refers to the presence of sufficient gamma radiation contaminants so that heavily shielded processing is required. Here, TRU implies the presence of TRU radionuclides such that isolation in the federal repository is the mandatory waste management practice. The implication of TRU contamination is a state of suspicion for some wastes and fact for others. The second group is low-level TRU wastes. Processing of this waste need not be so heavily shielded as the intermediate-level. The third category is low-level non-TRU. These wastes may be isolated in shallow land burial due to the absence of TRU radionuclides. These wastes are derived from the fue 1 receiving and storage basin, and the $U_{6}$ conversion facility where the absence of TRU radionuclides can be verified. The fourth and fifth groups are TRU and non-TRU HEPA filters. These filters are designated according to their suspected or confirmed radioactivity. The non-TRU HEPA filters are derived from the air cleaning systems of the fuel receiving and storage basins and the UF 6 conversion facility.

The non-filter wastes generally consist of papers, gloves, containers, wipes and other miscellaneous combustible and compactible materials. Two unique constituents of the intermediate-level TRU waste are the bead resins and the degraded extractant, a siurry and liquid, respectively. The bead resins will result from the iodine removal from excess water or from solvent cleanup. They are composed of $50 \mathrm{wt} \%$ water and $50 \mathrm{wt} \%$ polystrene, a combustible organic. The degraded extractant is that solvent which can no longer be efficientiy used in the separations process. Its degradation is generaliy attributed to radiation damage. 
General trash is treated in a variety of ways. The intermediate-level, TRU waste is incinerated in a remote facility. The ashes are immobilized in concrete. The off gas is scrubbed in a wet scrubber which generates a "blowdown" solution. The blowdown is concentrated and immobilized in cement. The low-level, TRU trash is also incinerated, although in a contact incineration system. The blowdown is concentrated with that of the intermediate-level waste. The incinerators are both controlled air systems. Incineration is selected because of the likely requirement of non-combustibility of wastes to be isolated in the repository. The non-TRU trash is compacted in a contact system. This treatment is selected because of its apparent low cost and simplicity, along with the resultant volume reduction. HEPA filters are packaged in 80-gallon drums without treatment. TRU HEPA filters are packaged in a remote facility and non-TRU filters in a contact area.

- Wet Wastes. The fuel coprocessing facility wet wastes are divided into two categories, TRU and non-TRU, according to the suspected and confirmed presence of TRU radionuclides. The TRU wet wastes are the silica gel, a slurry resulting from zirconium and niobium removal from the purified uranium stream and uranium fluorinator residues. (7) In addition, the treatment of intermediate- and low-level TRU general trash results in significant quantities of wet wastes. The non-TRU wet wastes consist of concentrates and slurries from the spent fuel receiving and storage basin and from $U_{6}$ conversion (excluding the fluorinator for residues).

Wet wastes are immobilized in cement, utilizing a remote drum tumbling system. This treatment is selected because of the availability of the technology and the likely ban on combustible materials in the repository (which may remove asphalt as a candidate wet waste binder). Both TRU and non-TRU wastes are immobilized in the same facility. Administrative controls will segregate the waste types. All wastes are packaged in 55-gallon drums.

- Scrap. Scrap at the fuel coprocessing facility is divided into two categories, TRU and non-TRU, again according to the suspected presence of TRU radionuclides. Scrap is composed of failed equipment, worn out components, and miscellaneous items which are noncombustible and noncompatible. 
Scrap is decontaminated, disassembled if necessary, and packaged in 55-galion drums. The process is selected because of its simplicity. TRU and non-TRU scrap are packaged in different facilities, remote and contact, respectively.

- Off Gas. Seven separate gaseous waste streams constitute the fuel coprocessing facility radioactive off gas. These are listed below, along with an indication of source of origin.

Fuel shear and dissolver off gas is derived from the initial spent nuclear shearing and dissolution process. Primary radioactive constituents of this stream are the volatile fission product radionuclides, ${ }^{3} \mathrm{H},{ }^{14} \mathrm{C}, \mathrm{Kr}$, $X e$, and $I$. The nonvolatile fission product and actinide radionuclides are present only in small fraction.

Vessel off gas is derived from many sources throughout the facility. It serves as the vent for all process cells and many processes.

Main building heat, ventilation, and air-conditioning (HVAC) is derived from the galleries, laboratories, corridors, and areas of personnel access. There is no radioactivity routinely present in this off-gas stream.

Excess water is the overhead of the excess water vaporizer. This water is "excess" within the plant. Following thorough decontamination by ion exchange and repeated concentration, it is evaporated and discharged to the atmosphere. Its primary radioactive constituent is tritium, of which the majority of the plant input is discharged in this stream.

$\mathrm{UF}_{6}$ plant process off gas is derived from the conversion of uranyl nitrate to uranyl hexafluoride. It is contaminated, essentially, only by trace uranium.

Storage basin HVAC is derived from the spent fuel receiving and storage basin. Included is the air which sweeps the basin itself. No radioactive material will be routinely present in this off-gas stream. 
Mixed nitrate calciner off gas is derived from the calcination of the fission product spiked, uranium and plutonium nitrate solution. This off-gas stream will be radioactively contaminated with fractions of the fission product and actinide radionuclides present. It also will be rich in $\mathrm{HNO}_{3}$ and $\mathrm{NO}_{x}$.

Off-gas treatment varies depending on the expected level of radioactive contamination. Fuel shear and dissolver off gas is screened, condensed, scrubbed of iodine with silica gel, passed through a $\mathrm{NO}_{x}$ absorber, and routed to the vessel off-gas system. Noble gas, tritium and carbon-14 retention systems are not addressed here and are described in Reference 1 . The vessel off gas is condensed, scrubbed of iodine with silica gel, filtered for particulates, scrubbed for iodine again, filtered for particulates again, diluted with stack exhaust, and discharged. Excess water is evaporated in the general purpose concentrator, condensed, evaporated in the excess water vaporizer, diluted with stack exhaust, and discharged. $U_{6}$ plant process off gas is filtered for particulates, diluted with stack exhaust, and discharged, as is storage basin HVAC. Mixed nitrate calciner off gas is condensed, scrubbed or ruthenium, filtered for particulates, scrubbed of iodine and $\mathrm{NO}_{x}$, filtered for particulates again, diluted with stack exhaust, and discharged.

\subsubsection{Mixed Oxide Fuel Fabrication Facility Wastes}

Pretreated radioactive wastes at the mixed-oxide fuel fabrication facility (called MOX facility) are tabulated in Table 4.12, as normalized to a plantyear basis. The MOX facility fabricates 400 MTHM/plant-yr of MOX fuel during 300 days of operation. Details about waste volumes and radioactivities are given in Appendix C. In contrast to the fuel coprocessing facility wastes, all radioactive wastes from the MOX facility are TRU. This is because of the potential for TRU contamination in the wastes. Figure 4.12 provides the reference treatment systems and Table 4.13 gives the as-treated waste characteristics. Each type of waste and its treatment system are briefly discussed in the following paragraphs. 
TABLE 4.12. Pretreated Radioactive Waste from a

Mixed Oxide Fuel Fabrication Facility

$\begin{array}{lccc}\text { Waste Type } & \begin{array}{c}\text { Volume } \\ \text { (m/plant-yr })\end{array} & \begin{array}{c}\text { Radioactivity } \\ \text { (Ci/plant-yr) }\end{array} \\ \text { General Trash } & 240 & 3.6 \times 10^{4} \\ \text { Wet Waste } & 150 & 1.4 \times 10^{5} \\ \text { Scrap } & 160 & 4.9 \times 10^{3} \\ \text { Off Gas } & 4.4 \times 10^{8} & 5.4 \times 10^{1}\end{array}$

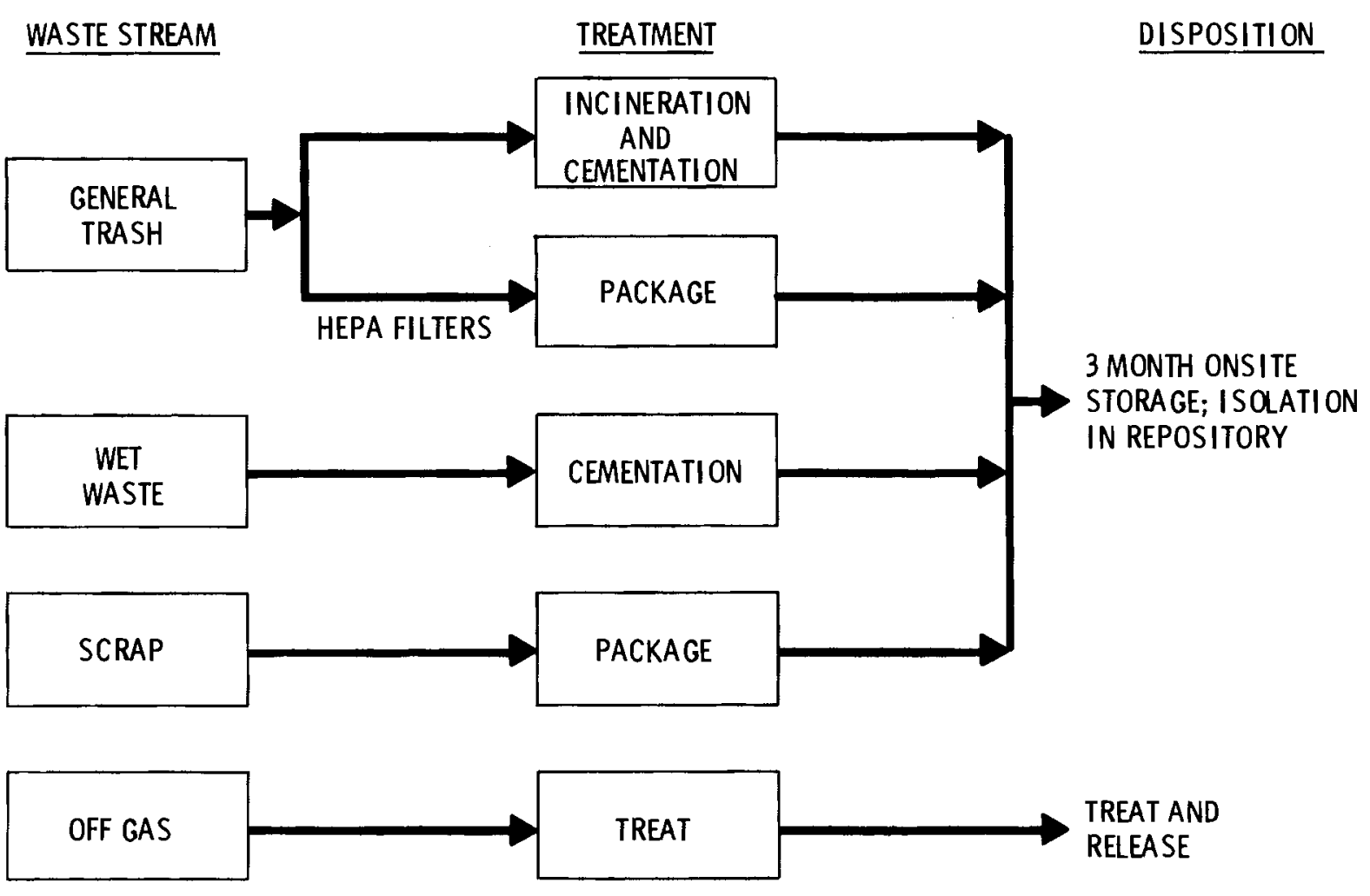

FIGURE 4.12. Mixed Oxide Fuel Fabrication Facility Radioactive Waste Management Strategy 
TABLE 4.13. Characterization of As-Treated Radioactive Wastes
from the Mixed Oxide Fuel Fabrication Facility (a)

\begin{tabular}{|c|c|c|c|}
\hline Waste Type & $\begin{array}{l}\text { Treated Volune, } \\
\left(\mathrm{m}^{3} / \mathrm{pl} \text { ant-yr }\right)\end{array}$ & $\begin{array}{l}\text { Number of Containers/ } \\
\text { plant-yr }\end{array}$ & $\begin{array}{l}\text { Radioactivjty/ } \\
\text { Container(b) (Ci) }\end{array}$ \\
\hline $\begin{aligned} \text { General } & \text { trash } \\
\text { non-filter } & \text { filters }(c)\end{aligned}$ & $\begin{array}{r}210 \\
40\end{array}$ & $\begin{array}{r}1,010 \\
140\end{array}$ & $\begin{array}{r}13 \\
160\end{array}$ \\
\hline Wet waste & 240 & 1,140 & 120 \\
\hline Scrap & 170 & 800 & 6.1 \\
\hline Off gas & $\mathrm{N} / \mathrm{A}$ & $N / A$ & $N / A$ \\
\hline
\end{tabular}

(a)All waste-types are treated in a 55 -gallon drum, $0.21 \mathrm{~m}^{3}$; following treatment, all wastes are stored onsite for three months and subsequently isolated in the repository.

(b) Average radioactivity per container at time of immobilization.

(c) HEPA filters are packaged in 80-gallon drums, $0.31 \mathrm{~m}^{3}$.

- Wet Wastes. Wet wastes in a MOX facility are derived from fuel pellet washing, cladding, etching, decontamination and fuel recovery (commonly called scrap recovery). Some small fraction of the fission product spiked $\mathrm{UO}_{2}-\mathrm{PuO}_{2}$ powder becomes so contaminated with impurities during fuel fabrication that decontamination is required. This decontamination is done in such a way as not to compromise the proliferation safeguards of the spiking and denaturing done to the plutonium. In addition to these routine process wastes, treatment of general trash results in a significant quantity of wet wastes requiring immobilization. Wet wastes are immobilized in cement.

- Scrap. Scrap from the MOX facility consists of failed equipment and miscellaneous noncombustible and noncompactable items. Scrap is decontaminated, disassembled and packaged.

- Off Gas. The MOX facility gaseous waste includes the air filtration stream and vaporized excess water. The off gas is filtered through at least two HEPA banks and discharged. 


\section{REFERENCES}

1. U.S. Department of Energy, Technology for Commercial Radioactive Waste Management. DOE/ET-0028, May 1979.

2. U.S. Energy Research and Development Administration, Alternatives for Managing Wastes from Reactors and Post Fission Operations in the LWR Fuel Cycle. ERDA-76-43, May 1976.

3. J. T. Long, Engineering for Nuclear Fuel Reprocessing. Published by the American Nuclear Society, La Grange Park, IL, 1978.

4. Allied Gulf Nuclear Services, Barnwell Nuclear Fuels Plant Separations Facility, Final Safety Analysis Report. Docket 50332, October 1973.

5. Exxon Nuclear Co., Nuclear Fuel Recovery and Recycling Center, Preliminary Safety Analysis Report. XN-FR-32, Docket 50-664, Exxon Nuclear Co. Inc., Richland, WA, 1976.

6. Savannah River Laboratory, Alternate Fuel Cycle Technologies Quarterly Report, July-September, 1977. DPST-AFCT-77-1-3, pps. 65-70.

7. J. W. Voss, "Comparison of Bitumen and Cement Immobilization of Intermediate- and Low-Level Radioactive Waste, "Proceedings of the Waste Management ' 79 Symposium. Tucson, AZ, February 1979, Report No. PNL-SA-7499. 


\subsection{INITIAL APPLICATION OF THE ANALYSIS APPROACH}

The first two stages of the analysis approach outlined in Section 3.0 are applied to the once-through and coprocessed $\mathrm{UO}_{2}-\mathrm{PuO}_{2}$ reference facilities described in Section 4.0. The purpose of this initial analysis is to demonstrate the analysis approach, provide relative comparisons between the oncethrough and the coprocessed fuel cycle waste management operations, and identify information needs required for a more comprehensive assessment. As outiined in Section 3.0, the consideration of routine releases, occupation exposure, accident releases, and costs are the primary areas of interest in evaluating a waste management system or operation. These areas are discussed for each reference facility in the following sections. A large amount of information is presented in this section. The reader who desires a brief overview is referred to Section 5.3 and its summary table.

\subsection{ANALYSIS OF THE ONCE-THROUGH FUEL CYCLE}

The waste management operations for the reference reactor, independent spent fuel storage basin, and packaging facility are analyzed below.

\subsubsection{Analysis of the Reference Reactor Waste Management Operations}

Table 5.1 gives the safety indices defined in Section 3.1 for the asgenerated and as-treated waste streams from the reference reactor. As seen from the table, the spent fuel waste stream is the smallest volume waste but the highest activity waste. On the basis of the toxicity index, spent fuel dominates the reactor waste streams. On a volume basis, the wet wastes are dominant but have many orders of magnitude lower safety indices than spent fuel. On the basis of safety emphasis required and potential treatment cost, it is expected that the spent fuel and the reactor wet wastes are the primary reactor waste streams of importance. The reactor off-gas waste stream is also of interest in that it is released to the atmosphere, and its toxicity index represents a crude relative measure of actual public exposure rather than potential exposure from the other waste streams which are contained. 
TABLE 5.1. Safety Indices for Reactor Wastes (per plant year)

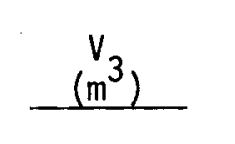

\begin{tabular}{l}
$M^{(a)}$ \\
$(\mathrm{kg})$ \\
\hline
\end{tabular}

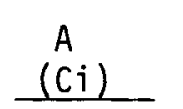

$\underline{\left(m^{3} \text { air }\right)}$

$\underline{\mathrm{GeV}-\mathrm{SeC})}$

HG

Compactable and

Combustible Trash

As-generated

As-treated

$\begin{array}{rl}170 & 2.1 \times 10^{4} \\ 46 & 2.6 \times 10^{4}\end{array}$

$\frac{12}{N C}(b) \quad \frac{1.8 \times 10^{10}}{N C}$

$2.9 \times 10^{11}$

$\begin{array}{ccc}6.2 \times 10^{-2} & 10^{-4} & 2 \\ N C & N C & N C\end{array}$

49

Wet Wastes

As-generated

As-treated

300

480

$$
\begin{aligned}
& 3.2 \times 10^{5} \\
& 8.6 \times 10^{5}
\end{aligned}
$$

$4.5 \times 10^{3}$

$9.3 \times 10^{12}$

$\frac{1.2 \times 10^{14}}{N C}$

$2.7 \times 10^{1}$

$10^{-3}$
$10^{-5}$

249

Non-combustible Trash

As-generated

As-treated

$\begin{array}{ll}34 & 8.4 \times 10^{3} \\ 36 & 1.3 \times 10^{4}\end{array}$

1

$1.9 \times 10^{9}$
NC

$2.5 \times 10^{10}$

NC

$\begin{array}{ccrc}5.2 \times 10^{-3} & 10^{-5} & 2 & 49 \\ \text { NC } & \text { NC } & \text { NC } & \text { NC }\end{array}$

Off gas
As-treated

$1.5 \times 10^{10}$

$1.9 \times 10^{10}$

$1.3 \times 10^{4}$

$5 \times 10^{10}$

$4.1 \times 10^{13}$

20.9

$5.1 \times 10^{5}$

$1.1 \times 10^{18}$

$4.6 \times 10^{4(c)}$

$\underset{N C}{1.1 \times 10^{8}}$

As-generated

NC

$\mathrm{NC}$

$3.1 \times 10^{18}$

NC

NC $\quad$ NC NC NC

(a) as-treated mass includes container

(b) NC = no change

(c) total weight including zircaloy and hardware

Definitions of Safety Indices

$V=$ volume of waste

$M=$ mass of waste

$A=$ activity of waste

$T I=$ toxicity index, volume of air to dilute to maximum permissible concentration (MPC)

$\mathrm{GP}=$ gamma power

$H G=$ heat generation
$M I=$ mobility index, nonleachable solid $=10^{-6} \rightarrow$ liquid $=10^{-3} \rightarrow$ gas $=1$

$A T=$ available technology index, similar waste routinely processed $=0$ unique processing required $=10$

$\mathrm{LL}=$ percent long-lived nuclides, greater than $\mathrm{T} 1 / 2=10$ years 
The more detailed analyses of the reactor waste management systems were not performed. The reference reactor and $i$ ts waste management operations are nearly identical for the once-through and the coprocessed fuel cycles so more detailed analyses for relative comparisons are not necessary.

\subsubsection{Analysis of the Reference Independent Spent Fuel Storage Facility Waste Management Operations}

Tables 5.2 and 5.3 provide the safety indices defined in Section 3.1 for the as-generated and as-treated waste streams from the reference ISFSF. As seen from the tables, the spent fuel operations are the dominant waste streams on the basis of radioactivity, toxicity, gamma power, and heat generation. On a volume basis, the as-generated compactable and combustible trash is slightly higher, but its safety indices are several orders of magnitude lower. The wet wastes are second to the spent fuel on a radioactivity, toxicity, gamma power, and heat generation basis. On the basis of safety emphasis required and potential treatment cost, it is expected that the spent fuel operations and the wet wastes are the primary waste streams of importance. The operational checklists as defined in Section 3.2 are given for these two waste streams in Tables 5.4 and 5.5 .

\subsubsection{Routine Releases}

The volume and activity of the ISFSF off gas shown in Table 5.2 includes the effluents from the waste treatment operations. As seen from the tables, the pertinent safety indices for the ISFSF off gas are $A=890 \mathrm{Ci}, T I=$ $3.1 \times 10^{9} \mathrm{~m}^{3}$ air, $L L=100 \%$. As shown on Table B.6, this release is dominated by ${ }^{85} \mathrm{Kr}$ released in the spent fuel receiving and storage operations. The use of simple index for routine releases defined in Section 3.2 (product of the toxicity index and the mobility index divided by one hundred to the power of the number of containment barriers) gives a value of $4.3 \times 10^{10}$ for the spent fuel receiving and storage operations and a value of $8.4 \times 10^{5}$ for the wet wastes. The relative ranking of the effluent index is probably useful, but it has several weaknesses. These include the situations above where the waste form can result in an inert gaseous release, the difficulty in defining the 
TABLE 5.2. Safety Indices for ISFSF Wastes (per plant year)

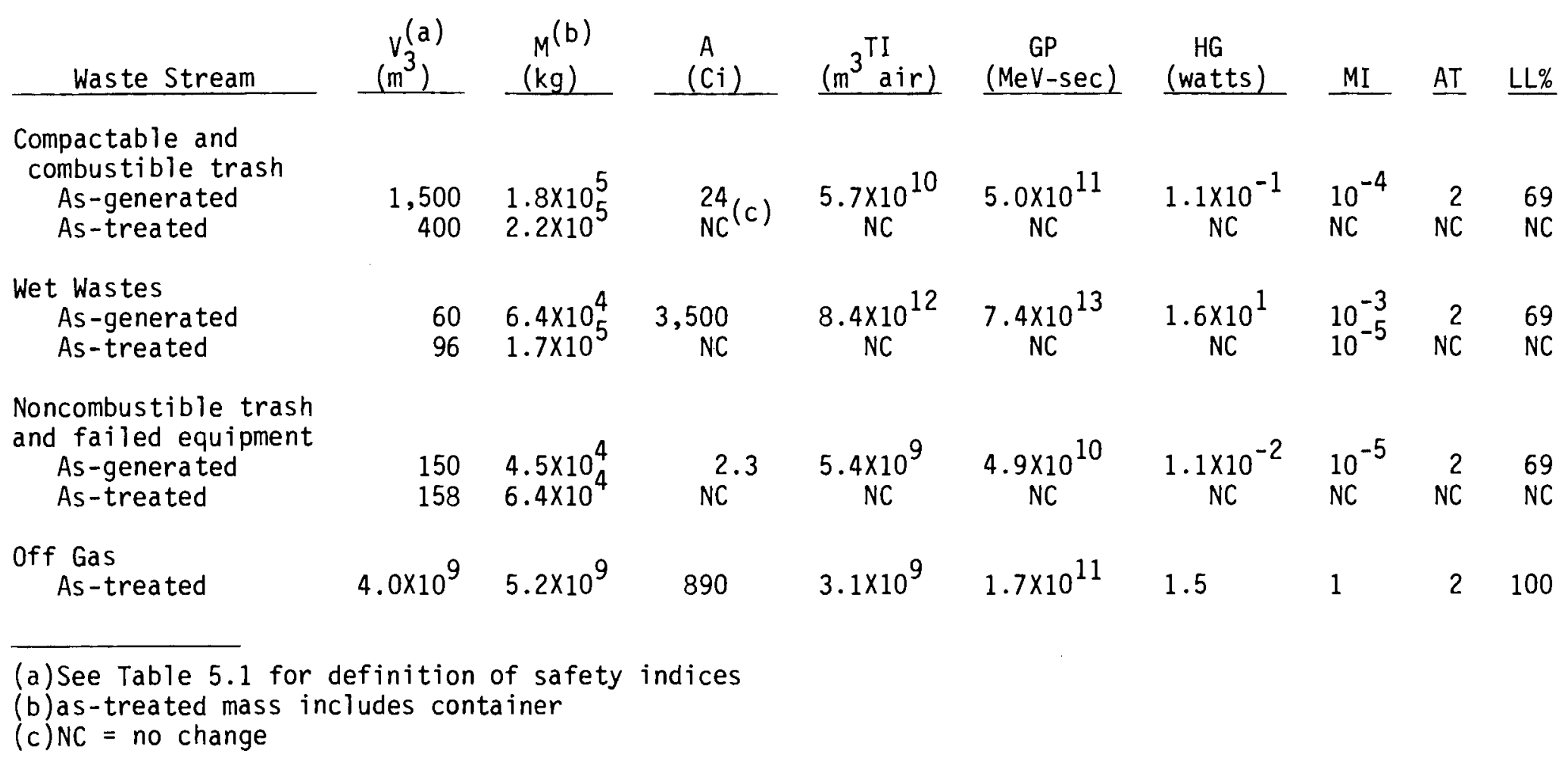


TABLE 5.3. Safety Indices for ISFSF Spent Fuel Operations

\begin{tabular}{|c|c|c|c|c|c|c|c|c|c|c|}
\hline Operation & $\begin{array}{c}\text { MTHM } \\
\text { Spent Fuel }\end{array}$ & $\begin{array}{l}v_{3}^{(a)} \\
\left(m^{3}\right)\end{array}$ & $\stackrel{M}{(\mathrm{~kg})}$ & $\begin{array}{l}A \\
(C i)\end{array}$ & $\left(m^{3^{T I}}\right.$ air $)$ & $\begin{array}{c}\mathrm{GP} \\
(\mathrm{MeV}-\mathrm{sec}) \\
\end{array}$ & $\begin{array}{c}H G \\
\text { (watts) }\end{array}$ & MI & $\underline{A T}$ & $\underline{\mathrm{LL} \%}$ \\
\hline $\begin{array}{l}\text { Receiving, } \\
\text { per year }\end{array}$ & $2,000^{(b)}$ & 830 & $2.9 \times 10^{6}$ & $2.4 \times 10^{9}$ & $1.7 \times 10^{20}$ & $2.3 \times 10^{19}$ & $1.0 \times 10^{7}$ & $10^{-6}$ & 4 & 43 \\
\hline Storage & $3,000^{(b)}$ & 1,240 & $4.4 \times 10^{6}$ & $2.1 \times 10^{9}$ & $2.6 \times 10^{20}$ & $2.1 \times 10^{19}$ & $8.1 \times 10^{6}$ & $10^{-6}$ & 2 & 40 \\
\hline $\begin{array}{l}\text { Transfer, } \\
\text { per year }\end{array}$ & $2,000^{(b)}$ & 830 & $2.9 \times 10^{6}$ & $8.9 \times 10^{8}$ & $1.6 \times 10^{20}$ & $7.4 \times 10^{18}$ & $2.9 \times 10^{6}$ & $10^{-6}$ & 4 & 54 \\
\hline
\end{tabular}

(a) See Table 5.1 for definition of safety indices.

(b) 500 MTHM per year of 0.5-year old spent fuel received for storage; 1500 MTHM per year of 6.5-year old spent fuel received for transfer to adjacent packaging facility; 500 MTHM per year of 6.5-year old spent fuel transferred from ISFSF to packaging facility; inventory of ISFSF 3000 MTHM of spent fuel at an average age of 3.5 years. 
TABLE 5.4. Checklist for Spent Fuel at ISFSF

\begin{tabular}{|c|c|}
\hline Processing Temperature & less than $120^{\circ} \mathrm{F}$ or $50^{\circ} \mathrm{C}$ \\
\hline Processing Pressure & $1 \mathrm{~atm}$ \\
\hline Processing Chemicals & none \\
\hline Number of Treatment Steps & 1-storage \\
\hline Number of Handling Steps & $\begin{array}{l}\text { Five: 1) receipt, 2) unload from shipping cask, } \\
\text { 3) } Q A /, 4 \text { ) place in basket, and } 5 \text { ) move to } \\
\text { storage. }\end{array}$ \\
\hline $\begin{array}{l}\text { Degree of Remote Processing } \\
\text { and Handling }\end{array}$ & remote $\left(10^{6}\right)$ \\
\hline $\begin{array}{l}\text { Intermediate Waste Form } \\
\text { and Characteristics }\end{array}$ & none \\
\hline $\begin{array}{l}\text { Energy Input Required and } \\
\text { Number of High Energy } \\
\text { Sources }\end{array}$ & $\begin{array}{l}\text { Mechanical energy for moving fuel; } 1 \text { high energy } \\
\text { source-hydraulic system; decay heat. }\end{array}$ \\
\hline $\begin{array}{l}\text { Degree of Concentration of } \\
\text { Radionuclides }\end{array}$ & High concentrated and localized to fuel \\
\hline $\begin{array}{l}\text { Final Waste Form and } \\
\text { Characteristics }\end{array}$ & Fuel assemblies in water storage. \\
\hline Manpower Required & 80 man-years/yr (reference 1$)$ \\
\hline $\begin{array}{l}\text { Degree of Maintenance } \\
\text { Required }\end{array}$ & 9 man-years/yr (reference 1$)$ \\
\hline Processing Time Required & $\begin{array}{l}5 \text { hours per cask; assemblies from receiving to } \\
\text { storage. }\end{array}$ \\
\hline $\begin{array}{l}\text { Estimated Radioactive } \\
\text { Effluents }\end{array}$ & See Table B.6 \\
\hline $\begin{array}{l}\text { Number of Barriers } \\
\text { From Waste To Environment }\end{array}$ & $\begin{array}{l}\text { Three: 1) Fuel integrity to hold radionuclides, } \\
\text { 2) pool water, and 3) vent system. }\end{array}$ \\
\hline Estimated Occupational Dose & 80 man-rem/year (reference 2) \\
\hline
\end{tabular}


TABLE 5.5. Checklist for Wet Waste Processing at ISFSF

\author{
Processing Temperature \\ Processing Pressure \\ Processing Chemicals \\ Number of Treatment Steps \\ Number of Handling Steps \\ Degree of Remote Processing \\ and Handling \\ Intermediate Waste Form \\ And Characteristics \\ Energy Input Required and \\ Number of High Energy \\ Sources
}

Degree of Concentration of Radionuclides

Final Waste Form and Characteristics

Manpower Required

Degree of Maintenance Required

Processing Time Required

Estimated Radioactive Effluents

Number of Barriers From Waste to Environment Estimated Occupationa 1 Dose $100^{\circ} \mathrm{C}$ (in concentrator)

$1 \mathrm{~atm}$

cement

Two: 1) concentration; 2) cementation

Six: 1) collect and store, 2) concentrate, 3) collect and store, 4) cement, 5) decontaminate and store, and 6) ship.

partially remote $\left(10^{2}\right)$

concentrated liquids

Energy Input: steam, high energy sources, steam in concentration, energy potential of of organic resins.

Average product concentration is $38 \mathrm{Ci} / \mathrm{m}^{3}$

Monolithic Solid

$690 \mathrm{man}-\mathrm{hr} / \mathrm{yr}$ or $1.5 \mathrm{man}-\mathrm{hr} / \mathrm{drum}$

$280 \mathrm{man}-\mathrm{hr} / \mathrm{yr}$

2 drum/hr

$3 \mathrm{E}-4 \mathrm{Ci} / \mathrm{yr} \mathrm{AP}$ and $1.6 \mathrm{E}-3 \mathrm{Ci} / \mathrm{yr} \mathrm{FP}$

to ISFSF vent system

Three: 1) integrity of waste form, 2) drum, and 3) waste facility.

0.5 man-rem 
TABLE 5.6. Postulated Accidents for Independent Spent Fuel Storage Facility ${ }^{(1)}$

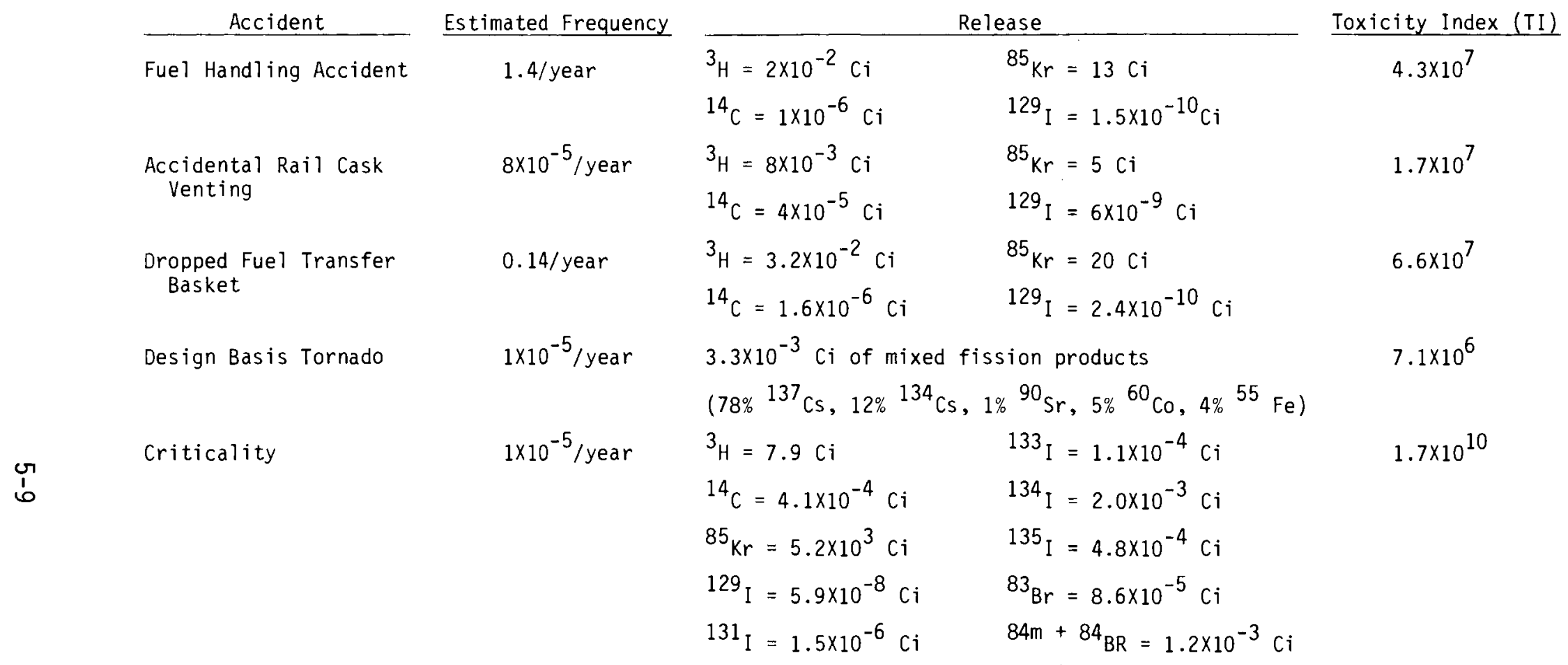


The accidents postulated in Table 5.6 and in reference 1 are design basis accidents; that is, accidents that have occurred or can be realistically postulated. One can postulate more severe accidents but their frequencies are typically correspondingly lower. These high consequence low frequency accidents may be of interest in the waste management system evaluation process. As discussed in Section 3.2, one approach is to compare directly the maximum physically possible releases for each waste process. A simpler measure may be to compare the maximum radioactive waste inventories for each waste process.

The maximum radioactive waste inventory for the independent spent fuel storage basin is one basin containing 500 MTHM of six-month old spent fuel. The pertinent safety indices for this inventory are $A=1.7 \times 10^{9} \mathrm{C} i$, $\mathrm{TI}=$ $4.9 \times 10^{19} \mathrm{~m}^{3}$ air, $G P=1.7 \times 10^{19} \mathrm{MeV} / \mathrm{sec}, H G=8.0 \times 10^{6}$ watts, and $M I=10^{-6}$. The highest release physically possible would probably result from a loss of cooling scenario with the unlikely failure of all the backup cooling systems. Heat-up and potential failure of the fuel elements could result in the release of significant quantities of the volatile radionuclides. The probability of this scenario is low and detailed heat transfer calculations must be performed to quantify any release. Reference 3 discusses some recent work in this area.

\section{1 .2 .4 Costs}

Since spent fuel is classified as a waste in the once-through fuel cycle, the ISFSF is a waste management facility and its cost will far exceed the costs of the ISFSF secondary waste streams. Table 5.7 presents operating and capital cost estimates for the ISFSF and its secondary waste stream management processes. This information is based on extrapolations from cost data given in reference 1 .

\subsubsection{Analysis of the Reference Spent Fuel Packaging Facility Waste Management Operations}

Tables 5.8 and 5.9 provide the safety indices defined in Section 3.1 for the as-generated and as-treated waste streams from the reference spent fuel packaging facility. As with the reactor and the ISFSF, the spent fuel operations are the dominant waste streams on the basis of radioactivity, toxicity, 
TABLE 5.7. Nuclear Waste Management Costs at an Independent Spent Fue1 Storage Facility

\section{Facility}

ISFSF Facility

Waste Management Facilities

Trash Compaction

Wet Waste Cementation

Noncombustible trash and

failed equipment packaging

off gas

$M=$ Million

$K=$ Thousand
Capital Cost (\$) Operating Cost (\$/Year)

$210 \mathrm{M}$

$5.6 \mathrm{M}$

$3 M$

$900 K$

$10 \mathrm{M}$

$400 \mathrm{~K}$

$1 \mathrm{M}$

$800 \mathrm{~K}$

$4 \mathrm{M}$

$100 \mathrm{~K}$

TABLE 5.8. Safety Indices for Packaging Facility Wastes (per plant-year)

\begin{tabular}{|c|c|c|c|c|c|c|c|c|c|}
\hline Waste Stream & $v_{\left(m^{3}\right)}^{(a)}$ & $\begin{array}{l}M^{(\mathrm{b})} \\
(\mathrm{kg})\end{array}$ & $\stackrel{A}{(C i)}$ & $\left(m^{3} \mathrm{Ti}\right.$ & $\begin{array}{c}\mathrm{GP} \\
(\mathrm{MeV}-\mathrm{sec}) \\
\end{array}$ & $\begin{array}{c}H G \\
\text { (watts) }\end{array}$ & MI & AT & $\underline{L L} \%$ \\
\hline $\begin{array}{l}\text { Compactable and } \\
\text { Combustible trash } \\
\text { As-generated } \\
\text { As-treated }\end{array}$ & $\begin{array}{l}550 \\
134\end{array}$ & $\begin{array}{l}6.6 \times 10^{4} \\
8.3 \times 10^{4}\end{array}$ & ${ }_{N C}^{1}(c)$ & $\begin{array}{c}1.6 \times 10^{9} \\
\mathrm{NC}\end{array}$ & $\begin{array}{c}3.7 \times 10^{10} \\
\mathrm{NC}\end{array}$ & $\begin{array}{c}6.7 \times 10^{-3} \\
N C\end{array}$ & $\begin{array}{c}10^{-4} \\
\mathrm{NC}\end{array}$ & $\begin{array}{l}2 \\
N C\end{array}$ & $\begin{array}{l}79 \\
\text { NC }\end{array}$ \\
\hline $\begin{array}{l}\text { Wet Wastes } \\
\text { As-generated } \\
\text { As-treated }\end{array}$ & $\begin{array}{l}20 \\
32\end{array}$ & $\begin{array}{l}2.1 \times 10^{4} \\
5.8 \times 10^{4}\end{array}$ & $\begin{array}{r}910 \\
\text { NC }\end{array}$ & $\begin{array}{c}1.3 \times 10^{12} \\
\mathrm{NC}\end{array}$ & ${ }_{\mathrm{NC}}^{1.6 \times 10^{13}}$ & $\begin{array}{r}3.4 \\
\mathrm{NC}\end{array}$ & $\begin{array}{l}10^{-3} \\
10^{-5}\end{array}$ & 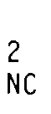 & $\begin{array}{l}79 \\
N C\end{array}$ \\
\hline $\begin{array}{l}\text { Noncombustible trash } \\
\text { and failed equipment } \\
\text { As-generated } \\
\text { As-treated }\end{array}$ & $\begin{array}{l}60 \\
63\end{array}$ & $\begin{array}{l}1.8 \times 10^{4} \\
2.6 \times 10^{4}\end{array}$ & NC & $\begin{array}{c}1.6 \times 10^{8} \\
\text { NC }\end{array}$ & $\begin{array}{c}3.7 \times 10^{9} \\
\text { NC }\end{array}$ & $\begin{array}{c}6.7 \times 10^{-4} \\
N C\end{array}$ & $10^{-5}$ & 2 & $\begin{array}{l}79 \\
N C\end{array}$ \\
\hline $\begin{array}{l}\text { Off gas } \\
\text { As-treated }\end{array}$ & $1.4 \times 10^{9}$ & $1.8 \times 10^{9}$ & 810 & $2.7 \times 10^{9}$ & $1.6 \times 10^{11}$ & 1.3 & 1 & 2 & 100 \\
\hline
\end{tabular}

(a) See Table 5.1 for definition of safety indices.

(b) as treated mass includes container

(c) $\mathrm{NC}=$ no change 
TABLE 5.9. Safety Indices for Packaging Facility Spent Fuel Operations

\begin{tabular}{|c|c|c|c|c|c|c|c|c|c|c|}
\hline Operation & $\begin{array}{c}\text { MTHM } \\
\text { Spent Fuel } \\
\end{array}$ & $\begin{array}{r}v^{(a)} \\
\left(m^{3}\right) \\
\end{array}$ & $\begin{array}{c}M \\
(\mathrm{~kg}) \\
\end{array}$ & $\begin{array}{c}A \\
(C i) \\
\end{array}$ & $\left(\mathrm{m}^{3^{T I}}\right.$ air $)$ & $\begin{array}{c}\mathrm{GP} \\
(\mathrm{MeV}-\mathrm{sec}) \\
\end{array}$ & $\begin{array}{c}H G \\
\text { (watts) }\end{array}$ & MI & AT & LL\% \\
\hline $\begin{array}{l}\text { Receiving, } \\
\text { per yearr }\end{array}$ & 2,000 & $8.3 \times 10^{2}$ & $2.9 \times 10^{6}$ & $8.9 \times 10^{8}$ & $1.6 \times 10^{20}$ & $7.4 \times 10^{18}$ & $2.9 \times 10^{6}$ & $10^{-6}$ & 4 & 54 \\
\hline Storage & 50 & $2.1 \times 10^{2}$ & $7.3 \times 10^{5}$ & $2.2 \times 10^{7}$ & $4.0 \times 10^{18}$ & $1.9 \times 10^{17}$ & $7.3 \times 10^{4}$ & $10^{-6}$ & 2 & 54 \\
\hline $\begin{array}{l}\text { Packaging }(b) \\
\text { and } \\
\text { shipping, } \\
\text { per year }\end{array}$ & 2,000 & $1.2 \times 10^{3}$ & $3.9 \times 10^{6}$ & $8.9 \times 10^{8}$ & $1.6 \times 10^{20}$ & $7.4 \times 10^{18}$ & $2.9 \times 10^{6}$ & $10^{-6}$ & 4 & 54 \\
\hline
\end{tabular}

(a) See Table 5.1 for definition of safety indices

(b)Fuel assemblies are individually packaged; packaging canister weighs $230 \mathrm{~kg}$ and its volume is $0.28 \mathrm{~m}^{3}$

gamma power, and heat generation. On a volume basis the packaged spent fuel is the dominant waste stream. The operational checklist for packaging spent fuel is given in Table 5.10.

\subsubsection{Routine Releases}

As seen from Table 5.8 the pertinent safety indices for the packaging facility off gas are $A=810 \mathrm{Ci}, T I=2.7 \times 10^{9} \mathrm{~m}^{3}$ air, and $L L=100 \%$. The release is nearly identical to the ISFSF. The simplified index for routine release defined in Section 3.2 gives a value of $3.2 \times 10^{10}$. The same qualifications on the use of this index given in Section 5.1.2 apply.

\subsubsection{Occupational Exposure}

Table 5.10 presents an estimate of 40 man-rem per year of occupational exposure in spent fuel packaging operations. The simplified index defined in Section 3.2 gives a value of $6 \times 10^{14}$ for use in relative comparisons.

\subsubsection{Accidental Releases}

Table 5.11 lists representative potential accidents postulated in reference 1 for a spent fuel packaging facility. The toxicity index is shown for each of the accidental releases. As seen from the table, the dropped fuel assemblies accident results in the highest toxicity index. As was true for the ISFSF, on an expected consequences basis the lower consequence high frequency fuel handling accident dominates. 


\section{TABLE 5.10. Checklist for Spent Fuel Packaging}

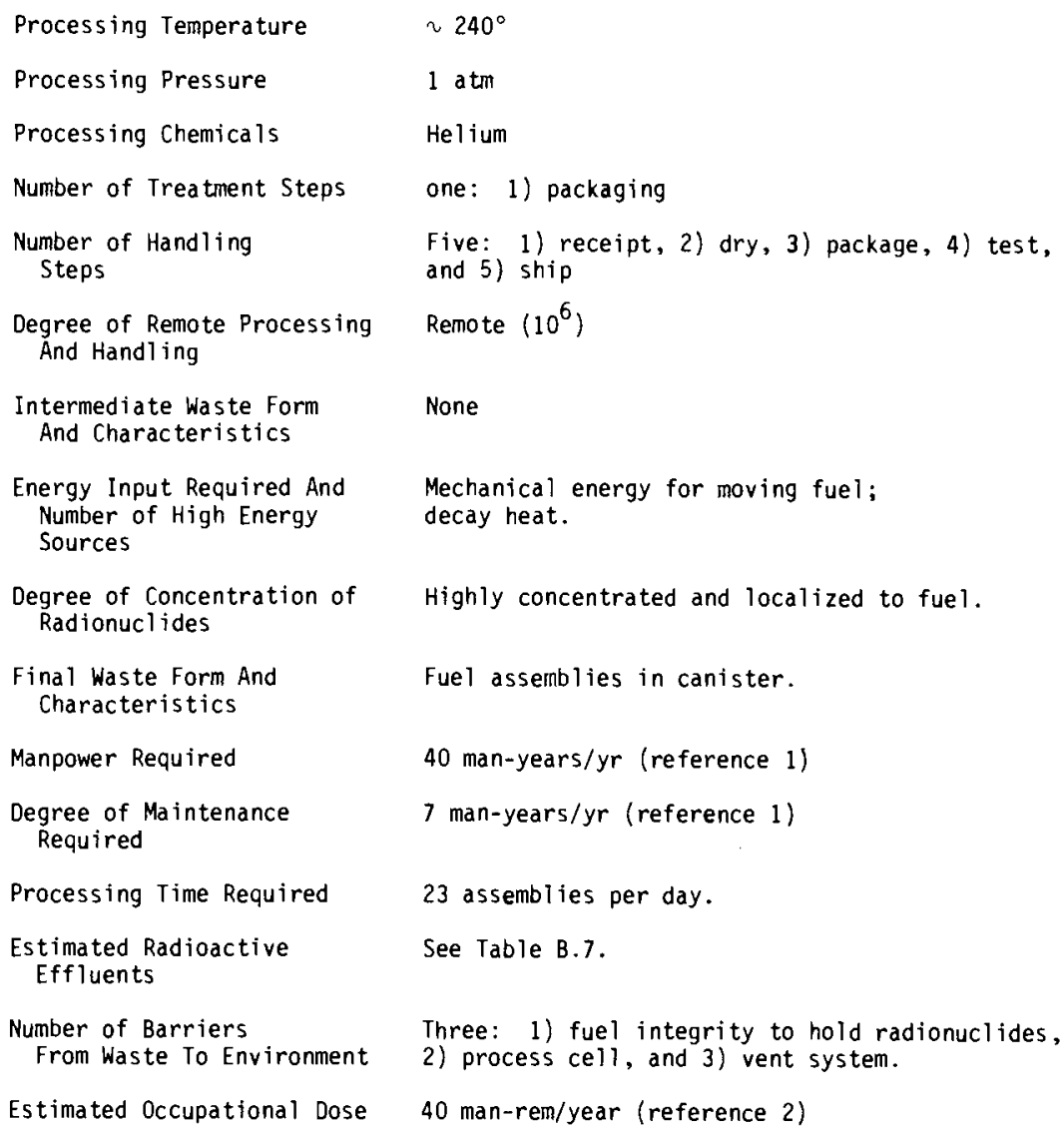

$40 \mathrm{man}-\mathrm{rem} /$ year (reference 2)

\section{TABLE 5.11. Postulated Accidents for Spent Fuel Packaging (1)}

\begin{tabular}{|c|c|c|c|c|}
\hline Accident & Estimated Frequency & & elease & Toxicity Index (TI) \\
\hline Fuel Handling Accident & $1.3 /$ year & $\begin{array}{l}{ }^{3} \mathrm{H}=1.4 \times 10^{-2} \mathrm{Ci} \\
{ }^{14} \mathrm{C}=1.0 \times 10^{-4} \mathrm{Ci} \\
{ }^{85_{\mathrm{Kr}}}=9.0 \mathrm{Ci} \\
{ }^{129} \mathrm{I}=1.5 \times 10^{-5} \mathrm{Ci}\end{array}$ & $\begin{array}{l}C_{5}=8.3 \times 10^{-10} \mathrm{Ci} \\
\text { Other } \mathrm{FP}=7.4 \times 10^{-10} \mathrm{Ci} \\
\text { Actinides }=4.1 \times 10^{-10} \mathrm{Ci} \\
\begin{array}{c}\text { Activation }=1.6 \times 10^{-11} \mathrm{Ci} \\
\text { products }\end{array}\end{array}$ & $3.10^{7}$ \\
\hline Dropped Fuel Assemblies & $0.01 /$ year & $\begin{array}{l}{ }^{3} \mathrm{H}=2.8 \times 10^{-1} \mathrm{Ci} \\
{ }^{14} \mathrm{C}=2.0 \times 10^{-3} \mathrm{Ci} \\
{ }^{85_{\mathrm{Kr}}}=180 \mathrm{Ci} \\
{ }^{129} \mathrm{I}=3.0 \times 10^{-4} \mathrm{Ci}\end{array}$ & $\begin{array}{l}\mathrm{C}_{\mathrm{S}}=1.7 \times 10^{-8} \mathrm{Ci} \\
\text { Other } \mathrm{FP}=1.5 \times 10^{-8} \mathrm{Ci} \\
\text { Actinides }=8.2 \times 10^{-9} \mathrm{Ci} \\
\begin{array}{c}\text { Activation } \\
\text { products }\end{array}\end{array}$ & $6 \times 10^{8}$ \\
\hline
\end{tabular}


The maximum radioactive waste inventory for the spent fuel packaging facility is the 50-MT surge storage basin. The pertinent safety indices for this inventory are $A=2.2 \times 10^{7} \mathrm{Ci}, \mathrm{TI}=4.0 \times 10^{18} \mathrm{~m}^{3}$ air, GP $=1.9 \times 10^{17} \mathrm{MeV} / \mathrm{sec}$, $H G=7.3 \times 10^{4}$ watts, and $M I=10^{-6}$. These indices are small when compared to the ISFSF maximum inventory. Since the age of the spent fuel is 6.5 years the heat generation rate is lower and a loss of cooling scenario would be less likely and result in smaller consequences.

\section{1 .3 .4 Costs}

The spent fuel packaging facility costs will far exceed the costs of the secondary waste management treatment systems. Table 5.12 gives operating and capital cost estimates for the spent fuel packaging facility and its secondary waste management operations. This information is based on extrapolations of cost data given in reference 1 .

TABLE 5.12. Nuclear Waste Management Costs at a Spent Fuel Packaging Facility

Facility

Packaging Facility

Waste Management Facilities

Trash Compaction

Wet Waste Cementation

Noncombustible trash and

failed equipment packaging

Off gas
Capital Cost $(\$)$ Operating Cost ( $\$ /$ Year)

$109 \mathrm{M}$

$11.4 \mathrm{M}$

(a)

$300 \mathrm{~K}$

(a)

$100 \mathrm{~K}$

(a)

$300 \mathrm{~K}$

$2 \mathrm{M}$

$100 \mathrm{~K}$

(a) Packaging facility is located adjacent to the ISFSF and utilizes the ISFSF Waste Management Facilities.

$M=$ Million

$K=$ Thousand 


\subsection{ANALYSIS OF THE COPROCESSED UO 2 FUEL CYCLE}

The waste management operations for the reference reactor, fuel coprocessing facility, and mixed oxide fuel fabrication facility are analyzed below.

\subsubsection{Analysis of the Reference Reactor Waste Management Operations}

The nuclear power plant waste management operations are nearly identical for the once-through and the coprocessing fuel cycles. One major difference is that spent fuel is not considered a waste in the coprocessing fuel cycle. Section 5.1.1 provides the analysis of the reactor waste management operations.

\subsubsection{Analysis of the Fuel Coprocessing Facility Waste Management Operations}

Table 5.13 presents the safety indices defined in Section 3.1 for the as-generated and as-treated waste streams from the reference fuel coprocessing facility. As seen from the table, the high-level liquid waste is the dominant waste stream on the basis of radioactivity, toxicity, gamma power, and heat generation. On a volume basis, the TRU scrap is the largest waste stream, but its safety indices are several orders of magnitude lower than those of high-level waste. The hulls and hardware are second to the spent fuel on a radioactivity, toxicity, gamma power, and heat generation basis. On the basis of safety emphasis required and potential treatment cost, it is expected that the high-level liquid waste and the hulls and hardware are the primary waste streams of importance. The operational checklists as defined in Section 3.2 are given for these waste streams in Tables 5.14 through 5.19.

\subsubsection{Routine Releases}

The volume and activity of the fuel coprocessing facility off gas shown in Table 5.13 includes the effluents from the waste treatment operations. As seen from the table, the pertinent safety indices are $A=8.8 \times 10^{6} \mathrm{Ci}$, $T I=3.8 \times 10^{13}$ and $L L=100 \%$. Table 5.20 provides estimates of the safety indices of the coprocessing plant waste process effluents. Details on these estimates are given in Appendix $C$. As seen from the table, the main plant off gas dominates the routine effluents. The simplified index for routine release defined in Section 3.2 gives a value of $2.7 \times 10^{13}$ for high-level waste and $4.1 \times 10^{7}$ for hulls and hardware. Again, potential problems are noted with the use of the simplified index, and it must be used with care. 
TABLE 5.13. Safety Indices for As-Generated and As-Treated Waste Streams at the Fuel Coprocessing Facility (per plant-year)

\begin{tabular}{|c|c|c|c|c|c|c|c|c|c|}
\hline Waste Stream & $\begin{array}{r}v_{3}^{(a)} \\
\left(m^{3}\right) \\
\end{array}$ & $\begin{array}{c}M \\
(\mathrm{~kg}) \\
\end{array}$ & $\stackrel{A}{(C i)}$ & $\left(m^{3^{T I}}\right.$ air $)$ & $\begin{array}{c}\text { GP } \\
(\mathrm{MeV}-\mathrm{sec})\end{array}$ & $\begin{array}{c}H G \\
\text { (watts) }\end{array}$ & MI & $\underline{A T}$ & LL\% \\
\hline $\begin{array}{c}\text { High-level liquid waste } \\
\text { As-generated } \\
\text { As-treated }\end{array}$ & $\begin{array}{r}1,420 \\
183\end{array}$ & $\begin{array}{l}1.8 \times 10_{5}^{7} \\
6.0 \times 10^{5}\end{array}$ & $\begin{array}{r}3.3 \times 10^{9} \\
N C\end{array}$ & $\begin{array}{c}2.8 \times 10^{20} \\
N C\end{array}$ & $\begin{array}{c}2.9 \times 10^{19} \\
N C\end{array}$ & $\begin{array}{c}1.9 \times 10^{7} \\
N C\end{array}$ & $\begin{array}{l}10^{-3} \\
10^{-6}\end{array}$ & $\begin{array}{l}3 \\
N C\end{array}$ & $\begin{array}{r}5 \\
N C\end{array}$ \\
\hline $\begin{array}{c}\text { Hulls and hardware } \\
\text { As-generated } \\
\text { As-treated }\end{array}$ & $\begin{array}{l}640 \\
670\end{array}$ & $\begin{array}{l}6.4 \times 10^{5} \\
3.4 \times 10^{6}\end{array}$ & $\begin{array}{c}2.1 \times 10^{7} \\
N C\end{array}$ & ${ }_{N C}^{5.0 \times 10^{17}}$ & ${ }_{N C}^{8.9 \times 10^{17}}$ & $\begin{array}{c}1.7 \times 10^{5} \\
\mathrm{NC}\end{array}$ & $10^{-6}$ & NC & $\begin{array}{l}50 \\
\text { NC }\end{array}$ \\
\hline $\begin{array}{l}\text { General Trash } \\
\text { TRU } \\
\text { As-generated } \\
\text { As-treated }\end{array}$ & $\begin{array}{r}3,700 \\
900\end{array}$ & $\begin{array}{l}5.3 \times 10^{5} \\
1.0 \times 10^{6}\end{array}$ & $\begin{array}{c}6.1 \times 10^{6} \\
N C\end{array}$ & $\begin{array}{c}4.0 \times 10^{17} \\
N C\end{array}$ & $\begin{array}{c}3.5 \times 10^{16} \\
N C\end{array}$ & $\begin{array}{c}3.0 \times 10^{4} \\
\mathrm{NC}\end{array}$ & $\begin{array}{l}10^{-4} \\
10^{-5}\end{array}$ & $\begin{array}{r}3 \\
N C\end{array}$ & $\begin{array}{l}3.9 \\
N C\end{array}$ \\
\hline $\begin{array}{l}\text { Non-TRU } \\
\text { As-generated } \\
\text { As-treated }\end{array}$ & $\begin{array}{r}1,300 \\
290\end{array}$ & $\begin{array}{l}1.6 \times 10_{5}^{5} \\
1.0 \times 10^{5}\end{array}$ & ${ }_{\mathrm{NC}}^{8.6 \times 10^{1}}$ & ${ }^{2.6 \times 10^{11}}$ & $\begin{array}{c}2.0 \times 10^{12} \\
N C\end{array}$ & $\begin{array}{l}0.40 \\
\mathrm{NC}\end{array}$ & $\begin{array}{l}10^{-4} \\
\mathrm{NC}\end{array}$ & $\begin{array}{r}3 \\
N C\end{array}$ & $\begin{array}{l}38 \\
N C\end{array}$ \\
\hline $\begin{array}{l}\text { Wet Waste } \\
\text { TRU } \\
\quad \text { As-generated } \\
\text { As-treated }\end{array}$ & $\begin{array}{r}80 \\
120\end{array}$ & $\begin{array}{l}1.1 \times 10_{5}^{5} \\
2.2 \times 10^{5}\end{array}$ & $\begin{array}{c}2.6 \times 10^{3} \\
N C\end{array}$ & $\begin{array}{c}8.7 \times 10^{14} \\
N C\end{array}$ & $\begin{array}{c}9.5 \times 10^{12} \\
N C\end{array}$ & $\begin{array}{r}9.1 \\
\mathrm{NC}\end{array}$ & $\begin{array}{l}10^{-3} \\
10^{-5}\end{array}$ & NC & $\begin{array}{l}26 \\
\text { NC }\end{array}$ \\
\hline $\begin{array}{l}\text { Non-TRU } \\
\text { As-generated } \\
\text { As-trea ted }\end{array}$ & $\begin{array}{l}190 \\
300\end{array}$ & $\begin{array}{l}2.2 \times 10^{5} \\
4.4 \times 10^{5}\end{array}$ & $\begin{array}{c}5.4 \times 10^{3} \\
N C\end{array}$ & $\begin{array}{c}9.1 \times 10^{12} \\
\mathrm{NC}\end{array}$ & $\begin{array}{c}1.4 \times 10^{14} \\
\mathrm{NC}\end{array}$ & ${ }^{28} \mathrm{NC}$ & $\begin{array}{l}10^{-3} \\
10^{-5}\end{array}$ & NC & $\begin{array}{l}43 \\
\text { NC }\end{array}$ \\
\hline $\begin{array}{l}\text { Scrap } \\
\text { TRU } \\
\text { As-generated } \\
\text { As-treated }\end{array}$ & $\begin{array}{l}1,400 \\
1,500\end{array}$ & $\begin{array}{l}4.4 \times 10_{5}^{5} \\
6.2 \times 10^{5}\end{array}$ & $\begin{array}{c}1.8 \times 10^{5} \\
\mathrm{NC}\end{array}$ & ${ }_{\mathrm{NC}}^{1.3 \times 10^{17}}$ & $\begin{array}{c}1.5 \times 10^{14} \\
\mathrm{NC}\end{array}$ & $\begin{array}{c}2.9 \times 10^{2} \\
N C\end{array}$ & $10^{-5}$ & $\begin{array}{r}3 \\
N C\end{array}$ & $\begin{array}{l}77 \\
\text { NC }\end{array}$ \\
\hline $\begin{array}{l}\text { Non-TRU } \\
\text { As-generated } \\
\text { As-treated }\end{array}$ & $\begin{array}{l}120 \\
130\end{array}$ & $\begin{array}{l}3.5 \times 10^{4} \\
5.1 \times 10^{4}\end{array}$ & $\begin{array}{r}3.3 \\
\mathrm{NC}\end{array}$ & $\begin{array}{c}5.3 \times 10^{9} \\
N C\end{array}$ & ${ }_{\mathrm{NC}}^{8.6 \times 10^{10}}$ & $\begin{array}{c}1.7 \times 10^{-2} \\
\mathrm{NC}\end{array}$ & ${ }_{\mathrm{NC}}^{10^{-5}}$ & $\begin{array}{r}3 \\
N C\end{array}$ & $\begin{array}{l}42 \\
\text { NC }\end{array}$ \\
\hline $\begin{array}{l}\text { Off gas } \\
\text { As-generated } \\
\text { As-treated }\end{array}$ & $\begin{array}{c}6.4 \times 10^{9} \\
N C\end{array}$ & $\begin{array}{c}7.6 \times 10^{9} \\
\text { NC }\end{array}$ & $\begin{array}{l}2.6 \times 10^{7} \\
8.8 \times 10^{6}\end{array}$ & $\begin{array}{l}9.6 \times 10^{17} \\
3.8 \times 10^{13}\end{array}$ & $\begin{array}{l}9.6 \times 10^{16} \\
2.0 \times 10^{15}\end{array}$ & $\begin{array}{l}8.8 \times 10^{4} \\
1.7 \times 10^{4}\end{array}$ & 1 & $\begin{array}{r}3 \\
N C\end{array}$ & $\begin{array}{r}49 \\
100\end{array}$ \\
\hline
\end{tabular}

(a) See Table 5.1 for definition of safety indices

(b) NC = no change 
TABLE 5.14. Checklist for HLLW ${ }^{(a)}$ Storage

Processing Temperature

Processing Pressure

Processing Chemicals

Number of Treatment Steps

Number of Handling Steps

Degree of Remote Processing and Handling

Intermediate waste Form and Characteristics

Energy Input Required and Number of High Energy Sources

Degree of Concentration of Radionuclides

Final Waste Form and Characteristics

Manpower Required

Degree of Maintenance Required

Processing Time Required

Estimated Radioactive

Effluents

Number of Barriers from Waste to Environment

Estimated Occupational Dose
Ranging from ambient to $100^{\circ} \mathrm{C}$.

Ambient

Nitric acid and sugar

Unless $\mathrm{pH}$ is being adjusted, there are no treatment steps

Three: transfer from: 1) routing tank to surge tanks, 2) to feed tank, and 3) to spray calciner

Totally remote $\left(10^{6}\right)$

Concentrated liquid waste

Input: cooling to control boiling Sources: energy content of waste

Very high $-8.6 \times 10^{6} \mathrm{ci} / \mathrm{m}^{3}$ or $3.3 \times 10^{4} \mathrm{Ci} / \mathrm{gallon}$.

Concentrated liquid waste

1 man-year/year (est.)

Very low

None; resident for 5 days (typ)

See Appendix C

For airborne release, Two: 1) in boiling controls, and 2) resident off-gas system are barriers

$1 \mathrm{man}-\mathrm{rem} /$ year (est)

(a) HLLW = High-level liquid waste. 
TABLE 5.15. Checklist for HLLW ${ }^{(a)}$ Calcination/Vitrification

Processing Temperature

Processing Pressure

Processing Chemicals

Number of Treatment Steps

Number of Handling Steps

Degree of Remote Processing

and Handling

Intermediate Waste Form and Characteristics

Energy Input Required and Number of High Energy Sources

Degree of Concentration of Radionuclides

Final Waste Form and Characteristics

Manpower Required

Degree of Maintenance Required

Processing Time Required

Estimated Radioactive Effluents

Number of Barriers from Wastes to Environment

Estimated Occupational Dose $1200^{\circ} \mathrm{C}(\max )$

Ambient

Glass Frit

Two: 1) calcination in spray calciner, and 2) vitrification in can melter.

Two: 1) transfer/injection to calciners, and 2) mix with glass frit in can melter.

Totally remote $\left(10^{6}\right)$

Spray calcine, fine powder of waste oxides

Input: electricity for resistance heaters High Energy Sources: electricity, waste potential

Very High: Input $=8.6 \times 10_{4}^{6} \mathrm{Ci} / \mathrm{m}^{3}$ or $3.3 \times 10^{4} \mathrm{Ci} / \mathrm{gal}$ lon

Output: $6.9 \times 10_{5}^{7} \mathrm{Ci} / \mathrm{m}^{3}$ or

$2.6 \times 10^{5} \mathrm{Ci} / \mathrm{galion}$

Uniform, monolithic glass solid

29 man-year/year (See reference 1).

Approximately $1 / 3$ of manpower or 9 man-year/ year (see reference 1 ).

300 days/year

See Appendix C

As airborne release, failure of off-gas system.

70 man-rem/year (See reference 2).

(a) HLLW = High-level 1 iquid waste 
TABLE 5.16. Checklist for HLLW ${ }^{(a)}$ off-Gas System

Processing Temperature
Processing Pressure
Processing Chemicals
Number of Treatment Steps

Number of Handling Steps

Degree of Remote Processing and Handling

Intermediate Waste Form and Characteristics

Energy Input Required and Number of High Energy Sources

Degree of Concentration of Radionuclides

Final Waste Form and Characteristics

Manpower Required

Degree of Maintenance Required

Process Time Required

Estimated Radioactive

Effluents

Number of Barriers from Waste to Environment

Estimated Occupational Dose

(a) HLLW = High-level liquid waste
Ambient

Ambient

Silica Gel, Zeolites

Six: 1) Venturi, 2) screen and condenser, 3) Ru absorber, 4) N0x destructor, 5) I scrub, and 6) particulate filtration.

Not applicable

Partialiy remote

Not applicable

Not applicable

Very low

Filtered off gas

Included in Table 5.15

Very low; filter changeout

Not applicable

See Appendix C

For airborne release, filtering system

Included in Table 5.15 
TABLE 5.17. Checklist from SHLW ${ }^{(a)}$ Seal, Weld, Inspection and Decontamination

Processing Temperature

Processing Pressure

Processing Chemicals

Number of Treatment Steps

Number of Handling Steps

Degree of Remote Processing and Handling

Intermediate Waste Form and Characteristics

Energy Input Required and Number of High Energy Sources

Degree of Concentration of Radionuclides

Final Waste Form and Characteristics

Manpower Required

Degree of Maintenance

Required

Processing Time Required

Estimated radioactive Effluents

Number of Barriers from Waste to Environment

Estimated Occupational Dose
High in welding; $100^{\circ} \mathrm{C}$ steam for decon.

Ambient

Decon solutions; dyes for NDT

Three: 1) seal/weld, 2) inspect, and 3) decontaminate

Four: Transfer canister to: 1) seal/weld;

2) inspection; 3) decon station, and

4) basin storage

Totally remote $\left(10^{6}\right)$

Not applicable

Input: electricity for welding; steam for decon

Sources: same; plus waste energy

Very high $-6.9 \times 10^{7} \mathrm{Ci} / \mathrm{m}^{3}$ or

$2.6 \times 10^{5} \mathrm{Ci} /$ galion

Monolithic glass solid in SS can

Included in Table 5.15

Included in Table 5.15

300 days/year

See Appendix C

As airborne release, three: 1) Glass form integrity, 2) canister, and 3) process offgas system.

Included in Table 5.15

(a) SHLW = Solidified high-level waste 
TABLE 5.18. Checklist for SHLW ${ }^{(a)}$ Onsite Water Bas in Storage

Processing Temperature

Processing Pressure

Processing Chemicals

Number of Treatment Steps

Number of Handling Steps

Degree of Remote Processing

and Handling

Intermediate Waste Form and Characteristics

Energy Input Required and Number of High Energy Sources

Degree of Concentration of Radionuclides

Final Waste Form and Characteristics

Manpower Required

Degree of Maintenance

Required

Estimated Radioactive

Effluents

Number of Barriers from Waste to Environment

Estimated Occupational Dose $40^{\circ} \mathrm{C}$

Ambient

$\mathrm{NaOH} ; \mathrm{HNO}_{3} ;$ detergent

One: 1) Storage in water-filled basin

None in routine storage

Remote $\left(10^{6}\right)$

Not Applicable

Input: steam (instrument), electricity Sources: waste potential

Very high; see Table 5.15

Monolithic glass solid in SS canister

32 man-year/year (reference 1)

Approx. 25\% of manpower, 8 man-year/year

Processing Time Required 5 year's storage

See Appendix C

As airborne release, Four: 1) glass integrity, 2) canister, 3) water, 4) off-gas system

120 man-rem/year (reference 2)

(a) SHLW = Solidified high-level waste 
TABLE 5.19. Checklist for Hulls and Hardware Treatment

Processing Temperature

Processing Pressure

Processing Chemicals

Number of Treatment Steps

Number of Handling Steps

Degree of Remote Processing and Handling

Intermediate Waste Form and Characteristics

Energy Input Required and Number of High Energy Sources

Degree of Concentration of Radionuclides

Final Waste Form and Characteristics

Manpower Required

Degree of Maintenance Required

Processing Time Required

Estimated Radioactive Effluents

Number of Barriers from Waste to Environment

Estimated Occupational Dose
Ambient

Ambient

Sand

One: 1) package in sand

Four: 1) move to packaging, 2) move to weld/leak test, 3) move to decon, and 4) move to storage

Totally remote $\left(10^{6}\right)$

Segments, chips and fines of hulls and hardware

Input: none

Sources: none

High: As-generated - $3.9 \times 10^{4} \mathrm{Ci} / \mathrm{m}^{3}$
As-treated - $3.7 \times 10^{4} \mathrm{Ci} / \mathrm{m}^{3}$

Matrix of Hulls and Hardware are with sand

8 man-year/plant-year (reference 1)

1 man-year/plant-year

2500 hours/year

See Appendix C

As airborne release, three: 1) integrity of waste form, 2) waste containers, and 3) off-gas sys tem

15 man-rem/plant year (reference 2). 
TABLE 5.20. Annual Effluent Characterization for Radioactive Waste Management at Fuel Coprocessing Plant (per plant-year)

\begin{tabular}{|c|c|c|c|}
\hline Waste Process & Radioactivity (Ci) & Toxicity Index $\left(\mathrm{m}^{3}\right.$ air $)$ & Long-Lived (Ci\%) \\
\hline High-level liquid Waste & 8,200 & $4.0 \times 10^{10}$ & 100 \\
\hline General Trash & 18 & $7.2 \times 10^{11}$ & 26 \\
\hline -TRU Trash Incineration & 18 & $7.2 \times 10^{11}$ & 26 \\
\hline -Non-TRU Trash Compaction & $2.3 \times 10^{-13}$ & $1.9 \times 10^{-3}$ & 33 \\
\hline -TRU HEPA Filter Packaging & $1.2 \times 10^{-7}$ & $5.9 \times 10^{2}$ & 0.46 \\
\hline -Non-TRU HELA Fil ter Packaging & $3.8 \times 10^{-13}$ & $5.3 \times 10^{-4}$ & 40 \\
\hline \multicolumn{4}{|l|}{ Wet Waste } \\
\hline -TRU Wet Waste & $2.5 \times 10^{-10}$ & 81 & 26 \\
\hline -Non-TRU Wet Was te & $5.3 \times 10^{-10}$ & 0.67 & 40 \\
\hline \multicolumn{4}{|l|}{ Scrap } \\
\hline$-T R U$ Scrap & $2.2 \times 10^{-10}$ & 130 & 77 \\
\hline -Non-Tru Scrap & $3.2 \times 10^{-14}$ & $5.1 \times 10^{-5}$ & 41 \\
\hline Main Plant Off Gas & $8.6 \times 10^{6}$ & $3.8 \times 10^{13}$ & 100 \\
\hline
\end{tabular}

\subsubsection{Occupational Exposure}

Table 5.14 through 5.18 present an estimate of 190 man-rem per year from high-level liquid waste processing and storage. Table 5.19 gives an estimate of 15 man-rem per year from hulls and hardware treatment. The simplified index defined in Section 3.2 results in a value of $4.9 \times 10^{15}$ for high-level waste and $7.1 \times 10^{12}$ for hulls and hardware for use in relative comparisons.

\subsubsection{Accidental Releases}

The high-level waste storage and processing operations represent the major accident potential for the coprocessing plant. Reference 1 postulates representative accidents for a fuel reprocessing plant. The high-level waste processing operations are nearly identical for the reference reprocessing facility in reference 1 and the reference coprocessing facility so these accidents are assumed to apply to the reference fuel coprocessing facility. The high-level 
liquid waste storage operations are different so representative accidents postulated for the liquid storage operations in reference 1 were not directly used.

Table 5.21 lists the representative accidents resulting in a release of radioactive material postulated for the high-level liquid waste processing and storage operations. The toxicity index (TI) is shown for each of the radioactive releases from the postulated accidents. As seen from the table, the contamination of the secondary cooling water during storage accident results in the highest toxicity index, but has the lowest frequency of occurrence. The toxicity indices of the more frequent accidents are at least four orders of magnitude lower. On the basis of mathematically expected consequences, the calcination/vitrification process off-gas filter failure is the dominant accident of those postulated.

The maximum radioactive waste inventories for each of the high-level waste processing and storage operations give a crude measure of worst-case accident potential. The maximum inventory for the liquid high-level waste storage operations is a 10,000-gallon titanium storage tank. The pertinent safety indices for this inventory are $A=1.4 \times 10^{8} \mathrm{Ci}, \mathrm{TI}=1.2 \times 10^{19} \mathrm{~m}^{3}$ air, $\mathrm{GP}=$ $1.2 \times 10^{18} \mathrm{MeV} / \mathrm{sec}, H G=8 \times 10^{5}$ watts, and $\mathrm{MI}=10^{-3}$. The maximum inventory in the spray/calciner/in-can melting process operations is one canister of molten waste. The pertinent safety indices are $A=5.1 \times 10^{6} \mathrm{Ci}, T O=4.3 \times 10^{17} \mathrm{~m}^{3}$ air, $\mathrm{GP}=4.5 \times 10^{16} \mathrm{MeV} / \mathrm{sec}, \mathrm{HG}=2.9 \times 10^{4}$ watts, and $\mathrm{MI}=10^{-3}$. The maximum inventory in the solidified high-level waste storage operations is one basin containing 500 waste canisters. The safety indices for this inventory are $A=2.6 \times 10^{9} \mathrm{Ci}, \mathrm{TI}=2.2 \times 10^{20} \mathrm{~m}^{3}$ air, $G P=2.3 \times 10^{19} \mathrm{MeV} / \mathrm{sec}, H G=1.5 \times 10^{7}$ watts, and $M I=10^{-6}$.

The solidified high-level waste storage basin represents the largest inventory but it is also the least mobile waste. A loss of cooling scenario with the unlikely failure of all the backup cooling systems would be necessary to release significant quantities of radionuclides. The probability of this scenario is low. 
TABLE 5.21. Postulated Accidents for foprocessing High-Level Liquid Waste Operations (1)

Liquid Storage

Filter fire

\section{Calcination/Vitrification}

Solidified High-Level Waste Storage

Contamination of secondary cooling water
Frequency

$0.05 / \mathrm{yr}$
$\frac{\mathrm{TI}}{8.9 \times 10^{7}}$
Release

$0^{-4}$ gram calcine equivalent
Calcine spill from process irregularity
Process off-gas filter failure
$2 / y r$
$1.5 \times 10^{-8}$ calçine equivalent (a)
$1.3 \times 10^{4}$
$0.2 / \mathrm{yr}$
$1 \times 10^{-3}$ gram calcine
equivalent
$8.9 \times 10^{8}$

$10^{-5} / y r^{(b)}$

7 gram calcine $(a)$

$6.2 \times 10^{12}$

(a)for $1 \mathrm{~g}$ calcine equivalent release: ${ }^{(2)}$

$$
\begin{aligned}
& 3_{H}=8.6 \times 10^{-4} \mathrm{Ci} \quad{ }^{137} \mathrm{Cs}=2.4 \\
& { }^{90} \mathrm{Sr}=1.6 \mathrm{Ci} \quad{ }^{144} \mathrm{Ce}=6.1 \mathrm{Ci} \\
& { }^{106} \mathrm{Ru}=4.9 \mathrm{Ci} \quad 239 \mathrm{Pu}=4.6 \times 15^{5} \\
& { }^{165 \mathrm{~m}} \mathrm{Te}=6 \times 10^{-2} \mathrm{Ci} \quad 241_{\mathrm{Am}}=1.9 \times 10^{-2} \\
& { }^{127 \mathrm{~m}} \mathrm{Te}=1.1 \times 10^{-2} \mathrm{Ci} \quad{ }^{242} \mathrm{Cm}=2.6 \times 10^{-1} \\
& { }^{129} \mathrm{I}=4.6 \times 10^{-9} \mathrm{Ci} \quad{ }^{244} \mathrm{Cm}=1.9 \times 10^{-1} \\
& { }^{134} \mathrm{Cs}=3.0 \mathrm{Ci}
\end{aligned}
$$

(b) frequency of this, postulated accident estimated at $10^{-5} /$ year; a frequency value was not reported in reference 1 .

\subsubsection{Costs}

Table 5.22 presents operating and capital cost estimates for the coprocessing facility waste management operations.

\subsubsection{Analysis of the Mixed Oxide Fuel Fabrication Facility Waste Manage- ment Operations}

Table 5.23 gives the safety indices defined in Section 3.1 for the asgenerated and as-treated waste streams from the reference MOX fuel fabrication facility. As seen from this table, the general trash and the wet waste streams are the dominant waste streams. Tables 5.24-5.26 give the operational check lists for these waste streams. 
TABLE 5.22. Nuclear Waste Management Costs of the Fuel Coprocessing Plant(a)

\begin{tabular}{lcc}
\multicolumn{1}{c}{ Facility } & $\begin{array}{c}\text { Capital } \\
\text { Cost }(\$)\end{array}$ & $\begin{array}{c}\text { Operating } \\
\text { Costs }(\$ / \text { Year) }\end{array}$ \\
\cline { 1 - 2 } $\begin{array}{l}\text { Non-TRU Trash } \\
\text { compaction }\end{array}$ & $4.1 \mathrm{M}$ & $800 \mathrm{~K}$ \\
$\begin{array}{l}\text { TRU trash } \\
\text { incineration }\end{array}$ & $14.3 \mathrm{M}$ & $1.4 \mathrm{M}$ \\
$\begin{array}{l}\text { Wet waste } \\
\text { cementation }\end{array}$ & $13.8 \mathrm{M}$ & $2.0 \mathrm{M}$ \\
$\begin{array}{l}\text { Scrap } \\
\text { packaging }\end{array}$ & $23.0 \mathrm{M}$ & $1.5 \mathrm{M}$ \\
$\begin{array}{l}\text { HLLW calcination/ } \\
\text { vitrification }\end{array}$ & $47.0 \mathrm{M}$ & $6.1 \mathrm{M}$ \\
$\begin{array}{l}\text { SHLW basin } \\
\text { Storage }\end{array}$ & $84.0 \mathrm{M}$ & $2.5 \mathrm{M}$ \\
$\begin{array}{l}\text { Hul 1s and hardware } \\
\text { packaging }\end{array}$ & $14.9 \mathrm{M}$ & $4.3 \mathrm{M}$ \\
0ff-gas treatment & $44.6 \mathrm{M}$ & $1.6 \mathrm{M}$ \\
\end{tabular}

(a)Mid-1976 dollars. This information is based on values given in reference 1 .

TABLE 5.23. Safety Indices for As-Generated and As-Treated Waste Streams at the Mixed 0xide Fuel Fabrication Facility

\begin{tabular}{|c|c|c|c|c|c|c|c|c|c|}
\hline Waste Stream & $\left(m^{3}\right)$ & $\begin{array}{c}\mathrm{M} \\
(\mathrm{kg})\end{array}$ & ( $\left.{ }^{A} \mathrm{C} i\right)$ & $\left(\mathrm{m}^{3}{ }^{\mathrm{TI}}\right.$ air) & $\begin{array}{c}\mathrm{GP} \\
(\mathrm{MeV}-\mathrm{sec})\end{array}$ & $\begin{array}{c}H G \\
\text { (watts) }\end{array}$ & MI & AI & LL\% \\
\hline $\begin{array}{l}\text { General Trash } \\
\text { As-generated } \\
\text { As-treated }\end{array}$ & $\begin{array}{l}240 \\
630\end{array}$ & $\begin{array}{l}3.1 \times 10^{4} \\
3.9 \times 10^{5}\end{array}$ & $\begin{array}{c}3.6 \times 10^{4} \\
N C\end{array}$ & ${ }_{\mathrm{NC}}^{3.0 \times 10^{16}}$ & $\begin{array}{c}4.7 \times 10^{13} \\
\text { NC }\end{array}$ & $\begin{array}{c}2.0 \times 10^{2} \\
N C\end{array}$ & $\begin{array}{l}10^{-4} \\
15^{5}\end{array}$ & $\begin{array}{l}3 \\
\mathrm{NC}\end{array}$ & $\begin{array}{c}60 \text { (TRU) } \\
N C\end{array}$ \\
\hline $\begin{array}{l}\text { Wet Waste } \\
\text { As-generated } \\
\text { As-trea ted }\end{array}$ & $\begin{array}{l}150 \\
240\end{array}$ & $\begin{array}{l}1.8 \times 10^{5} \\
4.3 \times 10^{5}\end{array}$ & $\begin{array}{c}1.4 \times 10^{5} \\
\mathrm{NC}\end{array}$ & $\underset{N C}{2.1 \times 10^{16}}$ & ${ }_{\mathrm{NC}}^{2 \times 10^{15}}$ & $\begin{array}{c}7.3 \times 10^{2} \\
N C\end{array}$ & $\begin{array}{l}10^{-3} \\
10^{-5}\end{array}$ & $\begin{array}{l}1 \\
\text { NC }\end{array}$ & ${ }_{N C}^{6}(T R U)$ \\
\hline $\begin{array}{l}\text { Scrap } \\
\text { As-generated } \\
\text { As-treated }\end{array}$ & $\begin{array}{l}160 \\
170\end{array}$ & $\begin{array}{l}1.0 \times 10^{5} \\
1.2 \times 10^{5}\end{array}$ & $\begin{array}{c}4.9 \times 10^{3} \\
N C\end{array}$ & $4.1 \times 10^{13}$ & ${ }^{6.4 \times 10^{12}}$ & $\begin{array}{c}2.8 \times 10^{1} \\
N C\end{array}$ & $\begin{array}{l}10^{-6} \\
N C\end{array}$ & $\begin{array}{l}3 \\
\mathrm{NC}\end{array}$ & 71 (TRU) \\
\hline $\begin{array}{l}\text { Off gas } \\
\text { As-generated } \\
\text { As-treated }\end{array}$ & $\begin{array}{c}4.4 \times 10^{8} \\
\text { NC }\end{array}$ & $\begin{array}{c}5.1 \times 10^{8} \\
\text { NC }\end{array}$ & $\begin{array}{l}5.4 \times 10^{1} \\
6.2 \times 10^{-8} \\
2 \times 10^{-4}\end{array}$ & $\begin{array}{l}4.0 \times 10^{13} \\
1.8 \times 10^{2} \\
6.0 \times 10^{8}\end{array}$ & $\begin{array}{l}3.0 \times 10^{10} \\
1.1 \times 10^{3} \\
6.0 \times 10^{6}\end{array}$ & $\begin{array}{l}7.8 \times 10^{-2} \\
2.8 \times 10^{-10} \\
6.8 \times 10^{-6}\end{array}$ & $\begin{array}{l}1 \\
N C\end{array}$ & $\begin{array}{l}3 \\
\mathrm{NC}\end{array}$ & $\begin{array}{l}82 \\
6.9 \times 10^{-3} \\
56\end{array}$ \\
\hline
\end{tabular}


TABLE 5.24. Checklist for Trash Incineration at the MOX Plant

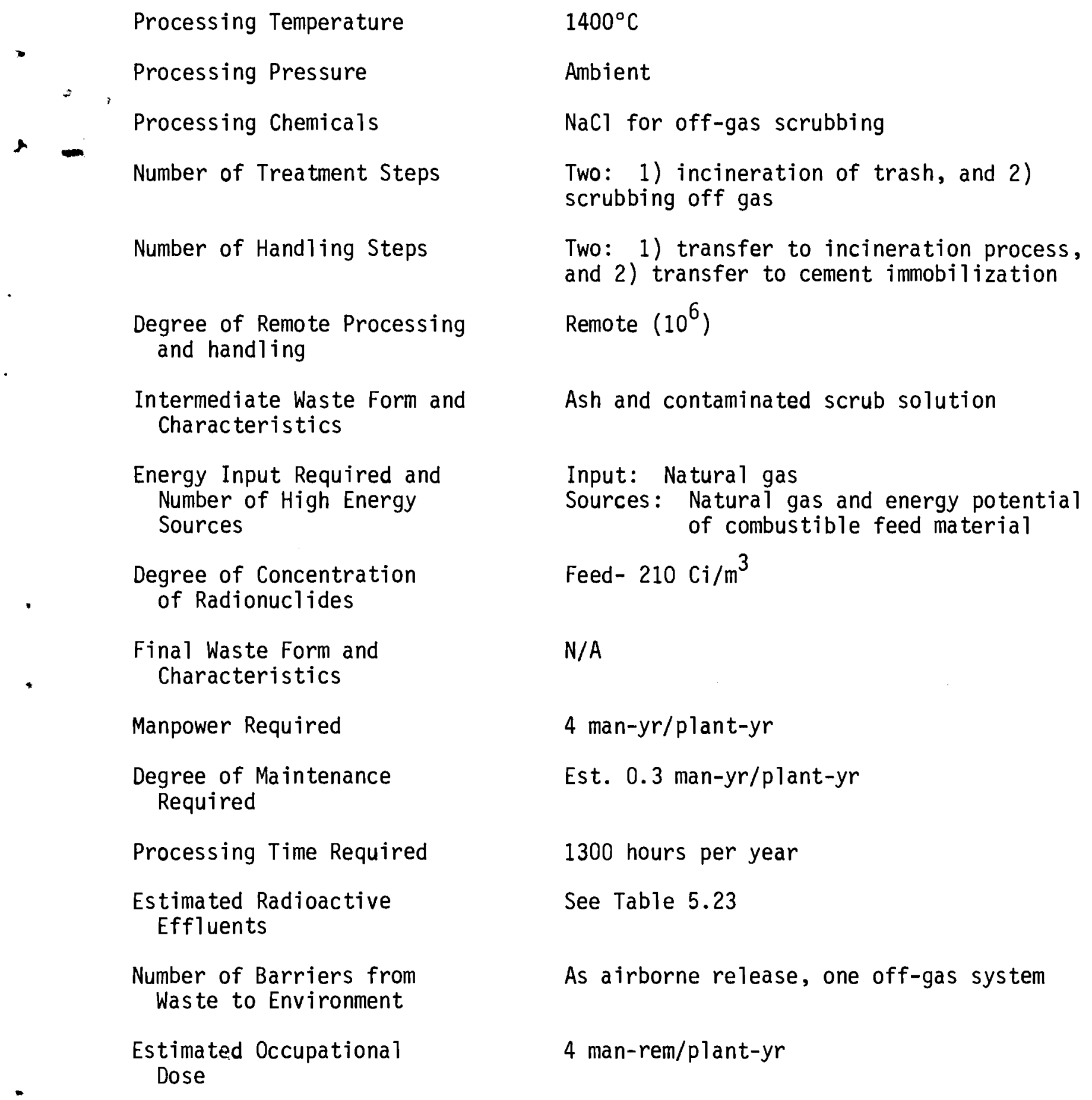


TABLE 5.25. Checklist for HEPA Filter Packaging at the MOX Plant

\begin{tabular}{|c|c|}
\hline Processing Temperature & Ambient \\
\hline Processing Pressure & Ambient \\
\hline Processing Chemicals & none \\
\hline Number of Treatment Steps & One: 1) package in drum \\
\hline Number of Handling Steps & $\begin{array}{l}\text { Four: 1) sea 1, 2) decontaminate, 3) assay, } \\
\text { and 4) move to storage }\end{array}$ \\
\hline $\begin{array}{l}\text { Degree of Remote Processing } \\
\text { and Handling }\end{array}$ & Remote $\left(10^{5}\right)$ \\
\hline $\begin{array}{l}\text { Intermediate Waste Form and } \\
\text { Characteristics }\end{array}$ & $\mathrm{N} / \mathrm{A}$ \\
\hline $\begin{array}{l}\text { Energy Input Required and } \\
\text { Number of High Energy } \\
\text { Sources }\end{array}$ & None \\
\hline $\begin{array}{l}\text { Degree of Concentration } \\
\text { of Radionuclides }\end{array}$ & $220 \mathrm{ci} / \mathrm{m}^{3}$ \\
\hline $\begin{array}{l}\text { Final Waste Form and } \\
\text { Characteristics }\end{array}$ & HEPA filters in 80 -gal drum \\
\hline Manpower Required & $2 \operatorname{man}-y r / p l a n t-y r$ \\
\hline $\begin{array}{l}\text { Degree of Maintenance } \\
\text { Required }\end{array}$ & $0.4 \mathrm{man}-\mathrm{yr} / \mathrm{plant}-\mathrm{yr}$ \\
\hline Processing Time Required & 100 days/plant-yr \\
\hline $\begin{array}{l}\text { Estimated Radioactive } \\
\text { Effluents }\end{array}$ & See Table 5.23 \\
\hline $\begin{array}{l}\text { Number of Barriers from } \\
\text { Waste to Environemnt }\end{array}$ & $\begin{array}{l}\text { As airborne release: three: 1) integrity } \\
\text { of the waste form, 2) integrity of the drum } \\
\text { and 3) the facility off-gas system }\end{array}$ \\
\hline $\begin{array}{l}\text { Estimated Occupational } \\
\text { Dose }\end{array}$ & 2 man-rem/plant-yr \\
\hline
\end{tabular}


TABLE 5.26. Checklist for Wet Waste Cement Immobilization at the MOX Plant

Processing Temperature

Processing Pressure

Processing Chemicals

Number of Treatment Steps

Number of Handling Steps

Degree of Remote Processing and Handiing

Intermediate Waste Form and Characteristics

Energy Input Required and Number of High Energy Sources

Degree of Concentration of Radionuclides

Final Waste Form and Characteristics

Manpower Required

Degree of Maintenance Required

Processing Time Required

Estimated Radioactive Effluents

Number of Barriers from Waste to Environment

Estimated Occupational Dose
Ambient

Ambient

Cement

Two: 1) feed into drum; and 2) mix it with cement

Four: 1) seal drum, 2) decontaminate the drum, 3) assay the drum and 4) move the drum to onsite storage

Remote $\left(10^{6}\right)$

Waste slurries, concentrates and powders

Input: mechanical energy to mix and move the drum;

Sources: none

As-generated: $\quad 2,100 \mathrm{Ci} / \mathrm{m}_{3}^{3}$

As-treated: $\quad 1,300 \mathrm{Ci} / \mathrm{m}^{3}$

Monolithic concrete solid in drum

1.4 man-yr/plant-yr

0.3 man-yr/plant-yr

100 days/plant-yr

See Table 5.23

As airborne release:, three: 1) integrity of the waste form, 2) integrity of the drum and 3 ) the facility off-gas system

$1.4 \mathrm{man}-\mathrm{rem} / \mathrm{plant}-\mathrm{yr}$ 


\subsubsection{Routine Releases}

The volume and activity of the MOX fuel fabrication facility off gas shown in Table 5.23 includes the effluents from the waste treatment operations. As seen from the table, the pertinent safety indices are $A=6.2 \times 10^{-8} \mathrm{Ci}$, $T I=\frac{1.8 \times 10^{2}}{6} \mathrm{~m}^{3}$ air, $L L=6.9 \times 10^{-3} \%$. These values are much smaller than those for the reference coprocessing facility.

\subsubsection{Occupational Exposure}

Tables 5.24-5.26 present an estimate of 6 man-rem per year for occupational exposure resulting from general trash processing operations and 1.4 man-rem per year for wet waste processing operations. The simplified index defined in Section 3.2 results in values of $2.8 \times 10^{9}$ for general trash and $1.7 \times 10^{9}$ for wet waste.

\subsubsection{Accidental Releases}

Table 5.27 gives representative accidents postulated in reference 1 for the trash incineration operations at the MOX-plant. The toxicity index (TI) is shown for the postulated releases. The incinerator explosion accident results in the highest toxicity index. On a mathematically expected consequence basis, the incinerator explosion also is the dominant accident of those postulated.

The largest radioactive inventory of waste is $60 \mathrm{~m}^{3}$ of treated wet waste in onsite storage. The safety indices for this inventory are $\mathrm{A}=3.5 \times 10^{4} \mathrm{Ci}$, $T I=5.3 \times 10^{15} \mathrm{~m}^{3}$ air, $G P=3.0 \times 10^{14} \mathrm{MeV} / \mathrm{sec}, H G=1.8 \times 10^{2}$ watts, and $\mathrm{MI}=10^{-5}$. As seen from the low heat generation index, potential loss of cooling is not a major safety concern.

The potential for a large consequence release from MOX plant waste management operations is much smaller than that from the coprocessing facility.

\subsubsection{Costs}

Table 5.28 presents operating and capital cost estimates for the MoX fuel fabrication facility waste management operations. 
TABLE 5.27. Potential Accidents for MOX Plant Trash Incineration Operations (1) Accident Frequency

Fire in feed preparation line

$0.01 / y r$

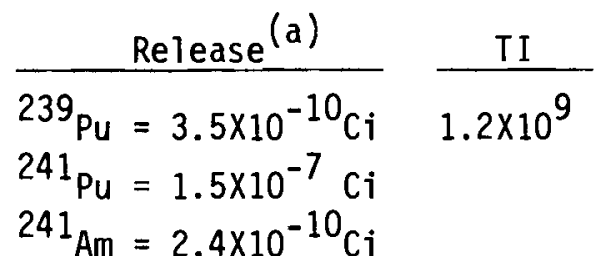

Explosions in feed preparation system

$0.02 / \mathrm{yr}$

${ }^{239} \mathrm{Pu}=8 \times 10^{-12} \mathrm{Ci}$

$2.8 \times 10^{7}$

$241_{\mathrm{Pu}}=3.5 \times 10^{-9} \mathrm{Ci}$

$241_{\mathrm{Am}}=5.5 \times 10^{-12} \mathrm{Ci}$

Incinerator explosion

$$
\begin{aligned}
& 0.01 / y r \quad{ }^{239} \mathrm{Pu}=1.4 \times 10^{-9} \mathrm{Ci} \\
& 241_{\mathrm{Pu}}=6.2 \times 10^{-7} \mathrm{Ci} \\
& 241_{\mathrm{Am}}=9.9 \times 10^{-10} \mathrm{Ci}
\end{aligned}
$$

(a)Fission products and other actinides are not numerically significant.

TABLE 5.28. Nuclear Waste Management Costs at the MOX Fabrication Plant(a)

\begin{tabular}{lrc}
\multicolumn{1}{c}{ Facility } & $\begin{array}{c}\text { Capital } \\
\text { Cost }(\$)\end{array}$ & $\begin{array}{c}\text { Operating } \\
\text { Cost }(\$ / \text { Year })\end{array}$ \\
\cline { 1 - 1 } $\begin{array}{l}\text { Trash } \\
\text { Incineration }\end{array}$ & $5.5 \mathrm{M}$ & $200 \mathrm{~K}$ \\
$\begin{array}{l}\text { Wet Waste } \\
\text { Cementation }\end{array}$ & $11.5 \mathrm{M}$ & $220 \mathrm{~K}$ \\
$\begin{array}{l}\text { Scrap } \\
\text { Packaging }\end{array}$ & $3.2 \mathrm{M}$ & $260 \mathrm{~K}$ \\
$\begin{array}{l}\text { Off-gas } \\
\text { treatment }\end{array}$ & $10.8 \mathrm{M}$ & $540 \mathrm{~K}$
\end{tabular}

(a)Mid-1976 dollars. This information is based on values given in reference 1 . 


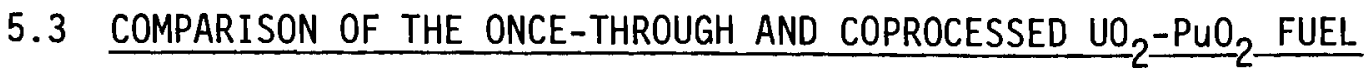 CYCLE WASTE MANAGEMENT OPERATIONS}

The discussions and tables in Sections 4.1, 4.2, 5.1, and 5.2 present the basic waste management characteristics of the once-through and the coprocessing facilities considered within the scope of this report. Table 5.29 presents a brief summary of some of the waste management characteristics for each facility. The reader is referred to the specific tables of interest in earlier sections for more detailed information.

As seen from the table, the highest activity waste is generated at the reactor for the once-through fuel cycle and at the reprocessing plant for the coprocessed $\mathrm{UO}_{2}-\mathrm{PuO}_{2}$ fuel cycle. As one would expect, the spent fuel and the solidified high-level liquid waste are the major waste streams on the basis of an activity, toxicity, gamma power and heat generation index. The largest volume of waste for any facility is generated at the coprocessing facility. The coprocessing facility also has the largest estimated occupational exposure, routine releases, waste management costs, and maximum single process or storage vessel radionuclide inventory.

The above comparisons are on an individual facility basis. A more relevant comparison would be on an overall fuel cycle basis with a common electrical generating capacity. Arbitrary fuel cycle scenarios of 200 reference reactors operating in the once-through and coprocessed $\mathrm{UO}_{2}-\mathrm{PuO}_{2}$ fuel cycles are defined for relative comparisons. The two fuel cycles are assumed to be operating at steady state.

In the once-through fuel cycle, 6380 MT of spent fuel are discharged each year. As was assumed in reference 1 , the reactor basins are assumed to have storage capacities sufficient to store $75 \%$ of this spent fuel for a 6.5 -year period. The remaining $25 \%$ of the spent fuel is stored at the reactors for 6 months and transferred to the independent spent fuel storage basin for a six-year storage period. The ISFSF has an adjacent packaging facility which receives and packages 6.5 year-old spent fuel from the reactor basins and the ISFSF. The packaging facility ships the packaged spent fuel to a repository. This fuel cycle operating at steady state requires approximately 
TABLE 5.29. Summary Table of Selected Characteristics of Once-Through and Coprocessing Fuel Cycle Facilities Waste Management Operations (per plant-year)

\begin{tabular}{|c|c|c|c|c|c|}
\hline Reactor & $\begin{array}{c}\text { Once-Through } \\
\text { ISFSF }\end{array}$ & Packaging & Reactor & $\begin{array}{l}\text { oprocessed } \mathrm{UO}_{2}-\mathrm{PuO}_{2} \\
\text { Coprocessing }\end{array}$ & MOX Plant \\
\hline $5.8 \times 10^{2}\left(2.7 \times 10^{3}\right)$ & $6.6 \times 10^{2}\left(3.1 \times 10^{3}\right)$ & $2.4 \times 10^{2}\left(1.1 \times 10^{3}\right)$ & $5.6 \times 10^{2}\left(2.7 \times 10^{3}\right)$ & $4.1 \times 10^{3}\left(1.6 \times 10^{4}\right)$ & $6.6 \times 10^{2}\left(3.1 \times 10^{3}\right)$ \\
\hline $1.1 \times 10^{8}\left(3.1 \times 10^{18}\right)$ & $3.5 \times 10^{3}\left(8.4 \times 10^{12}\right)$ & $9.1 \times 10^{2}\left(1.3 \times 10^{12}\right)$ & $4.5 \times 10^{3}\left(9.3 \times 10^{12}\right)$ & $3.3 \times 10^{9}\left(2.8 \times 10^{20}\right)$ & $1.8 \times 10^{5}\left(5.1 \times 10^{16}\right)$ \\
\hline $1.3 \times 10^{4}\left(5.0 \times 10^{10}\right)$ & $8.9 \times 10^{2}\left(3.1 \times 10^{9}\right)$ & $8.1 \times 10^{2}\left(2.7 \times 10^{9}\right)$ & $1.3 \times 10^{4}\left(5.0 \times 10^{10}\right)$ & $8.8 \times 10^{6}\left(3.8 \times 10^{13}\right)$ & $\begin{array}{l}6.2 \times 10^{-8}\left(1.8 \times 10^{2}\right) \\
9.2 \times 10^{-4}\left(6.0 \times 10^{8}\right.\end{array}$ \\
\hline (a) & 80 & 40 & (a) & 210 & 7 \\
\hline (a) & 240 & 120 & (a) & 270 & 32 \\
\hline $1.1 \times 10^{8}\left(3.1 \times 10^{18}\right)$ & $1.7 \times 10^{9}\left(4.9 \times 10^{19}\right)$ & $2.2 \times 10^{7}\left(4.0 \times 10^{18}\right)$ & $1.1 \times 10^{3}\left(2.3 \times 10^{12}\right)$ & $2.6 \times 10^{9}\left(2.2 \times 10^{20}\right)$ & $3.5 \times 10^{4}\left(5.3 \times 10^{15}\right)$ \\
\hline
\end{tabular}

(a) Not estimated; assumed identical for each fuel cycle 
11,000 MT of storage capacity and 6500 MT of receiving and packaging capacity. Approximately four reference independent spent fuel storage facilities with adjacent packaging facilities are required.

In the coprocessed $\mathrm{UO}_{2}-\mathrm{PuO}_{2}$ fuel cycle, 6380 MT of spent fuel are discharged from the reactors each year and stored in reactor basins for 6 months. 6380 MT of 6-month-old spent fuel are transferred to the coprocessing facility, stored for one year, and coprocessed. A MOX fuel fabrication facility receives the coprocessed uranium and plutonium and supplies the reactor with recycle fuel. This fuel cycle, operating at a steady state, (makeup plutonium and uranium are received from external sources) requires approximately three reference coprocessing facilities and 16 MOX fuel fabrication plants.

Thus, for crude comparative purposes, the values in Table 5.29 can be multiplied by: 200 for the reactors, four for the ISFSF and packaging facilities, three for the coprocessing facility, and 16 for the MOX plant. Table 5.30 presents the values for the hypothesized once-through and coprocessed $\mathrm{UO}_{2}-\mathrm{PuO}_{2}$ fuel cycles. The total values of the waste management characteristics for each of the two, hypothetical fuel cycles are quite similar. The treated waste volume, treated waste radioactivity, and waste management costs are nearly identical for the hypothetical once-through and coprocessed $\mathrm{UO}_{2}-\mathrm{PuO}_{2}$ fuel cycles. The coprocessed $\mathrm{UO}_{2}-\mathrm{PuO}_{2}$ fuel cycle waste management operations have a factor of ten higher estimated release of routine effluents, and a factor of 1.5 higher estimated occupational exposure.

The preceding results are crude estimates for use in relative comparisons. The purpose of the initial analysis of the once-through and the coprocessed $\mathrm{UO}_{2}-\mathrm{PuO}_{2}$ fuel cycle waste management operations is to demonstrate the analysis approach. More detailed studies are required to develop more definitive values. Waste disposal operations are beyond the scope of the present study. These operations should be considered in any more detailed studies. 
TABLE 5.30. Summary Table for Once-Through and Coprocessing Fuel Cycle Waste Management Characteristics for a Hypothetical 200 Reactor Nuclear Economy (per year)

Treated Waste Volume $\mathrm{m}^{3}$, (Containers)

Treated Waste Radioactivity $\mathrm{Ci},(\mathrm{TI})$

Routine Effluents $\mathrm{Ci},(\mathrm{TI})$

Occupational Exposure from Waste Operations man-rem

Was te Management Costs (operating \& capital) millions of dollars

\begin{tabular}{|c|c|c|c|c|c|}
\hline \multicolumn{3}{|c|}{ Once-Through } & \multicolumn{3}{|c|}{ Coprocessed $\cup_{2}-\mathrm{PuO}_{2}$} \\
\hline Reactor & ISFSF & Packaging & Reactor & Coprocessing & MOX Plant \\
\hline $1.2 \times 10^{5}\left(5.4 \times 10^{5}\right)$ & $2.6 \times 10^{3}\left(1.2 \times 10^{4}\right)$ & $9.6 \times 10^{2}\left(4.4 \times 10^{3}\right)$ & $1.1 \times 10^{5}\left(5.4 \times 10^{5}\right)$ & $1.2 \times 10^{4}\left(4.8 \times 10^{4}\right)$ & $1.1 \times 10^{4}\left(5.0 \times 10^{4}\right)$ \\
\hline $2.2 \times 10^{10}\left(6.2 \times 10^{20}\right)$ & $1.4 \times 10^{4}\left(3.4 \times 10^{13}\right)$ & $3.6 \times 10^{3}\left(5.2 \times 10^{12}\right)$ & $9.0 \times 10^{5}\left(1.9 \times 10^{15}\right)$ & $9.9 \times 10^{9}\left(8.4 \times 10^{20}\right)$ & $2.9 \times 10^{6}\left(8.2 \times 10^{17}\right)$ \\
\hline $2.6 \times 10^{6}\left(1.0 \times 10^{13}\right)$ & $3.6 \times 10^{3}\left(1.2 \times 10^{10}\right)$ & $3.2 \times 10^{3}\left(1.1 \times 10^{10}\right)$ & $2.6 \times 10^{6}\left(1.0 \times 10^{13}\right)$ & $2.6 \times 10^{7}\left(1.1 \times 10^{14}\right)$ & $\begin{array}{l}9.9 \times 10^{-7}\left(2.9 \times 10^{3}\right) \\
1.5 \times 10^{-1}(9.6\end{array}$ \\
\hline
\end{tabular}

(a)

320

160

960

480
630

810
510

(a) Not estimated; assumed identical for each fuel cycle 


\section{REFERENCES}

1. U.S. Department of Energy, Technology for Commercial Radioactive Waste Management. DOE/ET-0028, May 1979.

2. U.S. Department of Energy, Environmental Aspects of Commercial Radioactive Waste Management. DOE/ET-0029, May, 1979.

3. A. S. Benjamin, D. J. McCloskey, D. A. Powers, and S. A. Dupree, Spent Fuel Heatup Following Loss of Water During Storage. NUREG/CR-0649, March 1979. 


\subsection{CONCLUSIONS AND RECOMMENDATIONS}

The analysis approach developed for waste management system comparisons provides a useful presentation and ranking technique and serves as an initial step for more detailed safety studies. The initial application of this approach to the once-through and the coprocessed $\mathrm{UO}_{2}-\mathrm{PuO}_{2}$ fuel cycles demonstrates the technique and provides some relative waste management comparisons.

On an overall basis, the waste management aspects of the two fuel cycles examined are quite similar. On an individual facility basis, the fuel coprocessing plant has the largest waste management impact. As one would expect, the important waste streams on a safety and cost basis are the spent fue 1 for the once-through fuel cycle and the solidified high-level waste for the coprocessed $\mathrm{UO}_{2}-\mathrm{PuO}_{2}$ fuel cycle.

The four evaluation parameters used in the study are routine releases, occupational exposure, accidental releases, and cost. The safety indices defined to approximate these impacts were generally found to be useful for preliminary comparisons. Substantial information gaps were encountered in the estimation of occupational exposures and accidental releases.

As alternative fuel cycles are proposed, the approach suggested in this report may provide a ranking of the fuel cycle waste streams and useful comparisons with existing fuel cycles. This information can be used to direct safety research and development on a time and cost effective basis.

For the case of the once-through fuel cycle, potential areas of research and development include a comparative assessment of waste treatment alternatives and a systematic safety assessment of spent fuel storage operations.

The primary purpose of this initial assessment is to demonstrate the analysis approach. The scope is limited to specific fuel cycle facilities. More detailed studies are required for the complete fuel cycle operations to properly evaluate the waste management characteristics and impacts. 
.

. 


\section{APPENDIX A}

GENERAL SAFETY ASSESSMENT METHODS 
APPENDIX A

\section{GENERAL SAFETY ASSESSMENT METHODS}

The objectives of a safety assessment may include:

- identifying potentially hazardous conditions or elements in a system or facility

- quantifying the potentially hazardous conditions or elements (may be in terms of probability, consequences, or both).

In some safety applications, the quantification step is not required. In most applications, some degree of quantification is necessary for relative or comparative safety assessment. If an absolute measure of the safety of a single system is required, much more stringent requirements are placed on the safety assessment method used.

As outlined by Haasl, ${ }^{(1)}$ there are basically four sources of information when analyzing the safety of a system or facility:

1. experience

2. testing

3. analysis

4. conjecture

For most systems or facilities, a combination of the above sources of information is required to perform a safety analysis.

A safety assessment method may be categorized in several different levels. It may be qualitative or quantitative. A safety assessment method may be inductive (what happens if?) or deductive (how can something happen?). It may be consequence-oriented or risk-oriented. The objectives and constraints of the safety analysis program of interest may require one or a combination of the above safety assessment method categories. 
Some of the basic safety assessment methods available include: preliminary hazards analysis, failure mode and effects analysis, decision trees (event trees), fault trees, and cause-consequence diagrams. Lambert ${ }^{(2)}$ gives a good survey of these methods.

A preliminary hazards analysis (PHA) is a qualitative assessment of the hazardous conditions and potential accidents in a system. A PHA is made early in the system life cycle and is usually presented in a tabular format. A failure mode and effects analysis (FMEA) is an inductive analysis that systematically analyzes component failure modes and identifies the resulting effect on the system. An FMEA is similar to the PHA in structure, but is much more detailed and can be quantitative.

Inductive methods, such as event trees, ${ }^{(3)}$ start with an assumed initial failure. Additional component failures required to obtain a release (system failure) are then identified. Fault tree analysis $(3,4)$ is a deductive process. The analyst assumes the occurrence of an event selected as the top, undesired event, constituting system failure. He then systematically works backward to identify component faults which could cause or contribute to the undesired events. A cause-consequence diagram ${ }^{(5)}$ incorporates both event and fault trees. A critical intermediate event is selected for study. Preceding events are analyzed by fault tree analysis. Events subsequent to the critical event are handled by event trees.

Supplement 1 gives simple examples of each of the above techniques. Each approach has its advantages and limitations and often a combination of techniques is advantageous.

Recent developments in the safety analysis area have focused on risk analysis. A risk analysis is a systematic method drawing on the above techniques to relate the probability of a hazardous condition to its consequence. For a nuclear-related system, a risk analysis consists of the following basic steps: 1) definition of the inventory of radioactive material and its containment/confinement barriers; 2) identification of potential failure modes; 3 ) estimation of the probability and amount of radioactive material released by the potential failure modes; 4 ) analys is of the consequences of the radioactive material released; and 5) estimation of the system risk. 
The most comprehensive risk assessment to date has been the WASH-1400 study of light water reactors. (3) Safety/risk analyses have been performed to various depths on other nuclear fuel cycle operations; however, none at the detailed level comparable to WASH-1400. Reference 6 reviews risk assessment methods and their potential application to nuclear waste management systems. Previous and ongoing studies on the risk/safety of high-level waste management systems are discussed along with their limitations and potential improvements. A method for the identification and preliminary evaluation of potential accident release sequences from nuclear fuel cycle facilities is discussed in references 7 and 8 .

The degree of detail in any risk analysis is limited by the amount of design information and the amount of directly applicable and readily available data. To date, risk assessment methods have been more successfully applied to operational or near-operational systems for which a moderate amount of operating experience is available. 


\section{REFERENCES}

1. D. F. Haasl, "Fault Tree Analysis." Course notes, Joint Center for Graduate Study, Richland, WA, February 1974, to be published in book form.

2. H. E. Lambert, Systems Safety Analys is and Fault Tree Analysis. UCID-16238, Lawrence Livermore Laboratory, University of CA, May 1973.

3. USAEC, Reactor Safety Study, An Assessment of Accident Risks in Commercial Nuclear Power Plants. WASH-1400, October 1975.

4. D. F. Haas1, "Advanced Concepts in Fault Tree Analysis." In Proc. Systems Safety Symp., Univ. of Wash. and the Boeing Co., Seattle, 1965.

5. D. S. Nielsen, "The Cause/Consequence Diagram Method as a Basis for Quantitative Reliability Analysis." Presented at the ENEA/CREST Meeting on Applicability of Quantitative Reliability Analysis of Complex Systems and Nuclear Plants in its Relation to Safety, Munich, May 1971.

6. P. J. Pelto, T. H. Smith and J.W. Bartlett, "Risk Assessment Methods for Nuclear Waste Management Systems." Presented to EPA Workshop on Issues Pertinent to Development of Environmental Protection Criteria or Radioactive Wastes, BNWL-SA-6135, Pacific Northwest Laboratory, Richland, Washington, February 1977.

7. T. H. Smith, P. J. Pelto, D. L. Stevens, G. D. Seybold, W. L. Purcell, and L. V. Kimmel, A Risk-Based Fault Tree Analysis Method for Identification, Preliminary Evaluation, and Screening of Potential Accidental Release Sequences in Nuclear Fuel Cycle Operations. BNWL-1959, Pacific Northwest Laboratory, Richland, Washington, January 1976.

8. P. J. Pelto and W. K. Winegardner, "A Risk Assessment Method for Nuclear Fuel Cycle Operations." Presented to the American Nuclear Society 23rd Annual Meeting, BNWL-SA-6064, Pacific Northwest Laboratory, Richland, Washington, June 1977 . 


\section{SUPPLEMENT 1}

\section{SAFETY METHOD EXAMPLES}


This hypothetical system consists of a tank containing a liquid under pressure. If released this liquid will react with air to form a hazardous particulate. The tank is surrounded by a normally vented structure containing a spray air cleaning system and a ventilation isolation system. The spray air cleaning system and the ventilation isolation system need electric power to function. In the case of power failure an emergency power system is available

\section{SPRAY AIR CLEANING SYSTEM}

\section{BUILDING STRUCTURE}

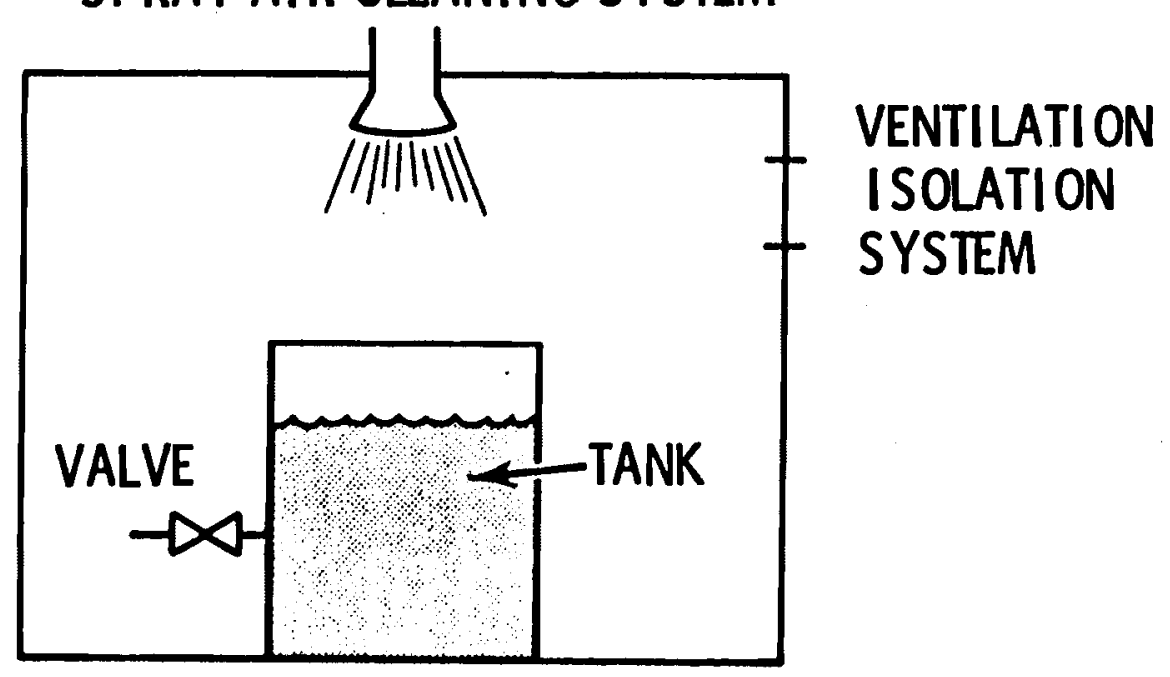


Valve

Tank

\section{Spray air cleaning}

system

\section{Ventilation Isolation} Sys tem

\section{Building structure}

Off-site electric power
Potential Hazard Condition

Failure of Valve (primary and external causes)

Failure of tank (primary and external causes)

Failure of system (primary and external causes)

Failure of system (primary and external causes)

Failure of structure (primary and external causes)

Failure of power (primary and external causes)

Existing Preventive and Control Measures

Effect

Release from tank

Release from tank

No cleaning of air in the event of a release from the tank

Release of particulate in the event of a release from the tank

Release of particulate in the event of a release from the tank

Failure of spray air cleaning and ventilation isolation systems
Valve maintenance and inspection; ventilation isolation system; spray air cleaning system.

Tank maintenance and inspection; ventilation isolation system; spray air cleaning system.

Maintenance, testing and inspection; ventilation isolation system.

Maintenance, testing and inspection.

Structure maintenance and inspection.

Emergency power system 
FAILURE MODES AND EFFECTS ANALYSIS

\begin{tabular}{|c|c|c|c|c|c|}
\hline Component & Failure Rate & Failure Mode & Effect on the System & Class & Compensating Provisions \\
\hline \multirow[t]{2}{*}{ Valve } & Probable & Fails closed & None & Safe & \\
\hline & $\begin{array}{l}\text { Reasonably } \\
\text { probable }\end{array}$ & Fails open & Release from tank & Critical & $\begin{array}{l}\text { Ventilation isolation system; } \\
\text { spray air cleaning system }\end{array}$ \\
\hline \multirow[t]{2}{*}{ Tank } & $\begin{array}{l}\text { Reasonably } \\
\text { probable }\end{array}$ & Leaks & Release from tank & Marginal & $\begin{array}{l}\text { Ventilation isolation system; } \\
\text { spray air cleaning system }\end{array}$ \\
\hline & Remote & Ruptures & Release from tank & Critical & $\begin{array}{l}\text { Ventilation isolation system; } \\
\text { spray air cleaning system }\end{array}$ \\
\hline $\begin{array}{l}\text { Spray air cleaning } \\
\text { system }\end{array}$ & $\begin{array}{l}\text { Reasonably } \\
\text { probable }\end{array}$ & $\begin{array}{l}\text { Fails to } \\
\text { function }\end{array}$ & $\begin{array}{l}\text { None unless } \\
\text { combined with } \\
\text { release from tank }\end{array}$ & Marginal & Ventilation isolation system \\
\hline $\begin{array}{l}\text { Ventilation } \\
\text { isolation system }\end{array}$ & $\begin{array}{l}\text { Reasonably } \\
\text { probable }\end{array}$ & $\begin{array}{l}\text { Faijs to } \\
\text { function }\end{array}$ & $\begin{array}{l}\text { None unless } \\
\text { combined with } \\
\text { release from tank }\end{array}$ & Marginal & \\
\hline Building Structure & Remote & $\begin{array}{l}\text { Containment } \\
\text { failure }\end{array}$ & $\begin{array}{l}\text { None unless } \\
\text { combined with } \\
\text { release from tank }\end{array}$ & Marginal & \\
\hline Off-site electric & Probable & $\begin{array}{l}\text { Fails to } \\
\text { function }\end{array}$ & $\begin{array}{l}\text { Fails spray air } \\
\text { cleaning and } \\
\text { ventilation } \\
\text { isolation system }\end{array}$ & Marginal & Emergency power system \\
\hline
\end{tabular}




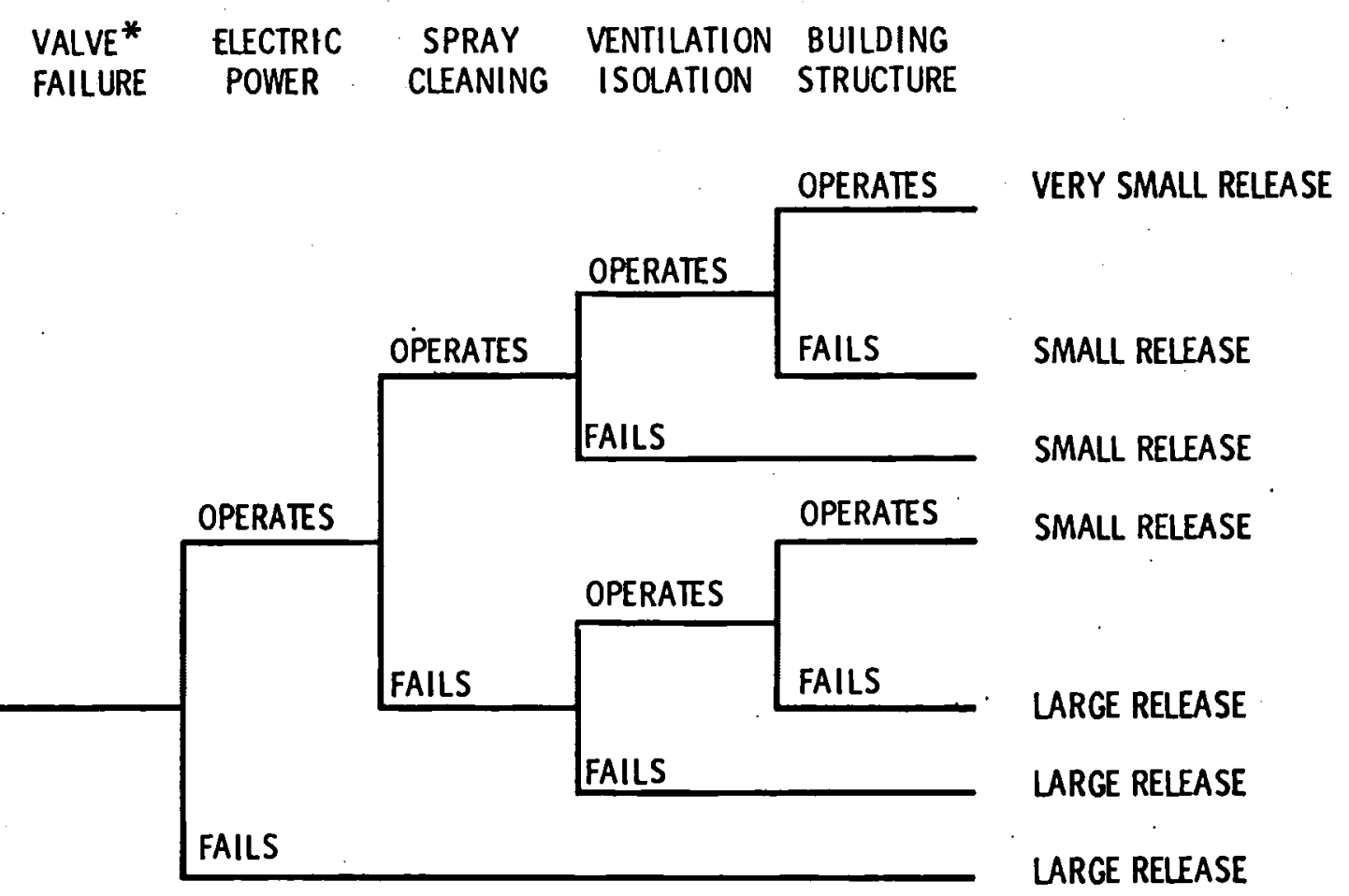

* VALVE faILURE IS PICKED AS INITIATING EVENT 
FAULT TREE

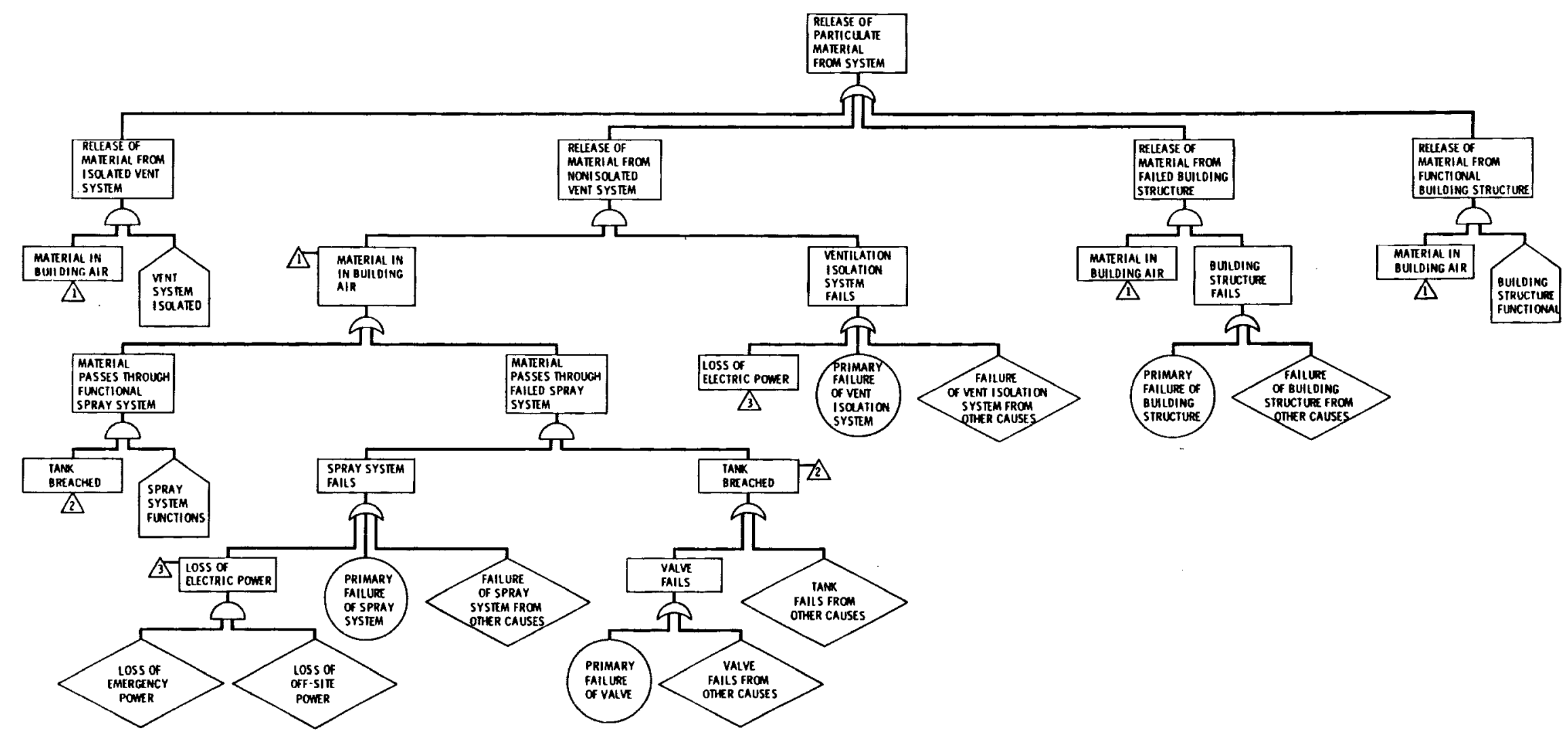




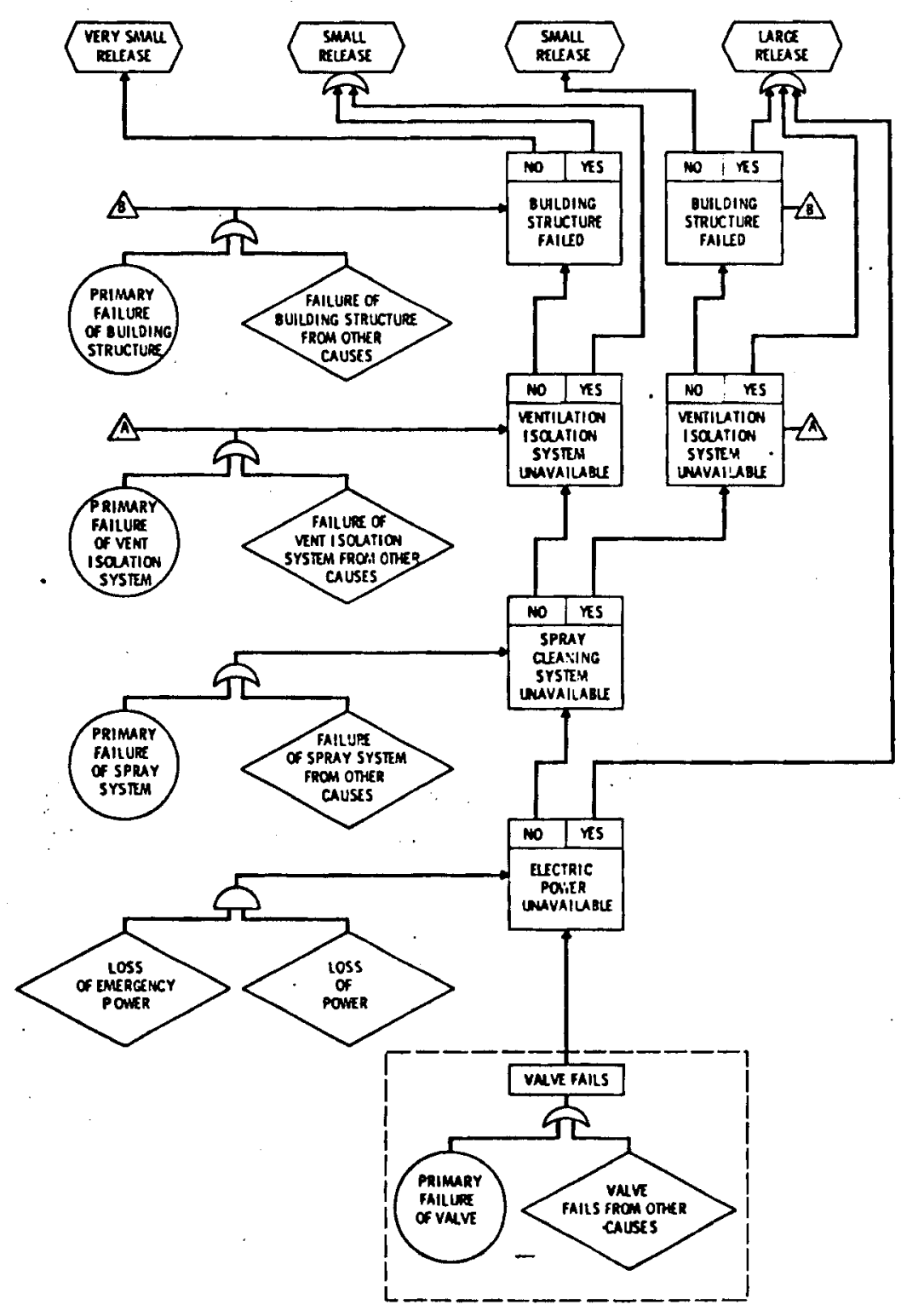


APPENDIX B

DETAILED RADIONUCLIDE INVENTORIES FOR ONCE-THROUGH FUEL CYCLE WASTE STREAMS 
TABLE B.1. Reactor Low Level Wastes

\begin{tabular}{|c|c|c|c|c|}
\hline \multirow[b]{2}{*}{ Waste Type } & \multirow{2}{*}{$\begin{array}{c}\text { As Generated } \\
\text { Volume } \\
\text { (m3/year) } \\
\end{array}$} & \multicolumn{3}{|c|}{ Radionuclide Content (Ci/year) } \\
\hline & & $3_{H}$ & $\begin{array}{l}\text { Activation } \\
\text { Products }(a) \\
\end{array}$ & $\begin{array}{l}\text { Fission } \\
\text { Products }(a)\end{array}$ \\
\hline \multicolumn{5}{|l|}{ Compactable and } \\
\hline Comidustiole waste & 170 & 3 & 4 & 5 \\
\hline Wet Wastes & 300 & 450 & 700 & 3350 \\
\hline \multicolumn{5}{|l|}{ Noncombustible } \\
\hline Trash & 34 & 0.09 & 0.14 & 0.67 \\
\hline
\end{tabular}

(a)Radionuclide inventory given in Table B.4. 


\section{TABLE B.2. Reference ISFSF Low Level Wastes}

\begin{tabular}{|c|c|c|c|}
\hline \multirow[b]{2}{*}{ Waste Type } & \multirow{2}{*}{$\begin{array}{c}\text { As Generated } \\
\text { Volume } \\
\left(\mathrm{m}^{3} / \text { year) }\right. \\
\end{array}$} & \multicolumn{2}{|c|}{$\begin{array}{c}\text { Radionuclide Content } \\
\text { ( } \mathrm{C} \mathrm{i} / \text { year })\end{array}$} \\
\hline & & $\begin{array}{l}\text { Activation } \\
\text { Products(a) }\end{array}$ & $\begin{array}{l}\text { Fission }(\mathrm{a}) \\
\text { Products }\end{array}$ \\
\hline $\begin{array}{l}\text { Compactable and } \\
\text { Combustible Waste }\end{array}$ & 1500 & 3 & 21 \\
\hline Wet Wastes & 60 & 430 & 3100 \\
\hline $\begin{array}{l}\text { Noncombustible Waste } \\
\text { and Failed Equipment }\end{array}$ & 150 & 0.3 & 2 \\
\hline
\end{tabular}

(a) Radionuclide inventory given in Table B.4. 
TABLE B.3. Spent Fuel Packaging Facility Low Level Wastes

\begin{tabular}{|c|c|c|c|}
\hline \multirow[b]{2}{*}{ Waste Type } & \multirow{2}{*}{$\begin{array}{c}\text { As Generated } \\
\text { Volume } \\
\text { (m³/year) } \\
\end{array}$} & \multicolumn{2}{|c|}{$\begin{array}{c}\text { Radionuclide Content } \\
(\mathrm{C} \text { i/year) }\end{array}$} \\
\hline & & $\begin{array}{l}\text { Activation } \\
\text { Products(a) } \\
\end{array}$ & $\begin{array}{l}\text { Fission } \\
\text { Products }(a)\end{array}$ \\
\hline $\begin{array}{l}\text { Compactable and } \\
\text { Combustible Waste }\end{array}$ & 550 & 0.6 & 0.3 \\
\hline Wet Wastes & 20 & 60 & 850 \\
\hline $\begin{array}{l}\text { Noncombustible Waste } \\
\text { and Failed Equipment }\end{array}$ & 60 & 0.06 & 0.03 \\
\hline
\end{tabular}

(a) Radionuclide inventory given in Table B.4. 
TABLE B.4. Definition of Activation and Fission Products for Once-Through Low Level Wastes

\begin{tabular}{lll} 
& \multicolumn{2}{c}{ Abundance $(\mathrm{Ci} \%)$} \\
\cline { 3 - 3 } Radionuclide & Reactor & ISFSF \\
Facility
\end{tabular}

Activation Products

$\begin{array}{lccc}{ }^{51} \mathrm{Cr} & 0.057 & 0.025 & - \\ { }^{54} \mathrm{Mr} & 2.43 & 1.41 & 0.065 \\ { }^{55} \mathrm{Fe} & 50.0 & 44.6 & 32.9 \\ { }^{59} \mathrm{Fe} & 0.43 & 0.21 & - \\ { }^{58} \mathrm{Co} & 15.7 & 7.66 & - \\ { }^{60} \mathrm{Co} & 31.4 & 46.1 & 67.1\end{array}$

Fission Products

$\begin{array}{cccc}{ }^{89} \mathrm{Sr} & 0.45 & 0.15 & - \\ { }^{90} \mathrm{Sr} & 0.83 & 1.14 & 1.36 \\ { }^{95} \mathrm{Zr} & 0.02 & 0.007 & - \\ { }^{103} \mathrm{Ru} & 0.002 & 0.001 & - \\ { }^{106} \mathrm{Ru} & 0.048 & 0.02 & 0.125 \\ { }^{127 \mathrm{~m}} \mathrm{Te} & 0.21 & 0.07 & - \\ { }^{129 M} \mathrm{Te} & 0.02 & 0.008 & - \\ { }^{134} \mathrm{Cs} & 50.6 & 30.3 & 20.7 \\ { }^{137} \mathrm{Cs} & 47.7 & 68.3 & 77.7 \\ { }^{141} \mathrm{Ce} & 0.002 & 0.001 & - \\ { }^{144} \mathrm{Ce} & 0.12 & 0.04 & 0.068\end{array}$


TABLE B.5. Reference Nuclear Power Plant Off Gas( $(\mathrm{a})$

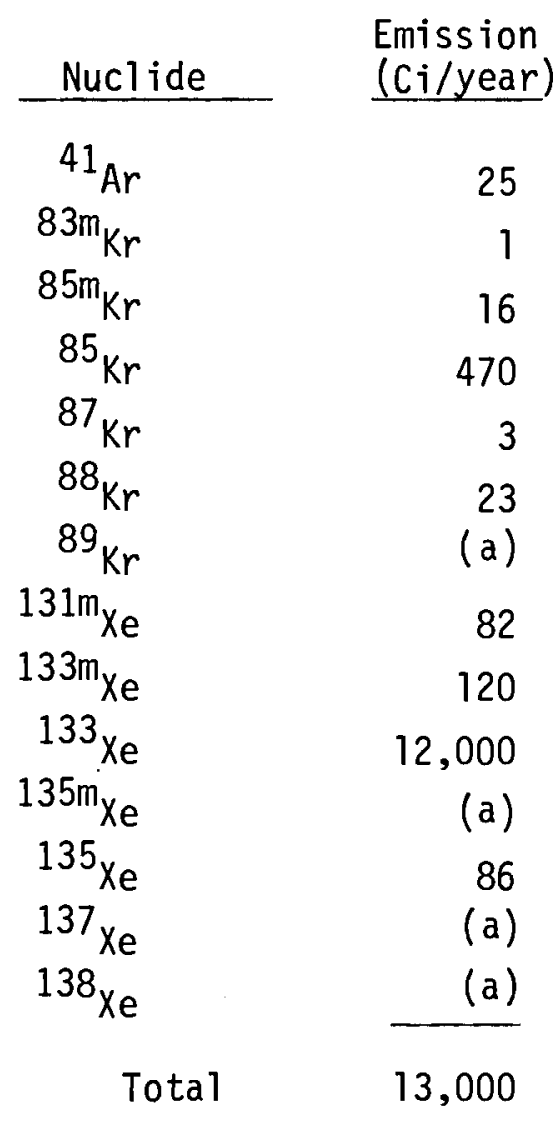

0thers

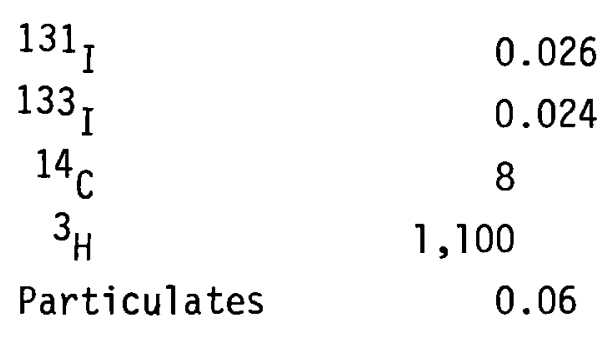

(a) Values taken from Table IV C-21, Reference 1. 
IABLE B.6. Reference ISFSF off Gas ${ }^{(a)}$

\begin{tabular}{|c|c|}
\hline Radionuclide & $\begin{array}{r}\text { Releases } \\
\text { (Ci/year) }\end{array}$ \\
\hline $3_{H}$ & 2.4 \\
\hline${ }^{14} \mathrm{C}$ & $3.3 \times 10^{-3}$ \\
\hline${ }^{58} \mathrm{Co}$ & $6.3 \times 10^{-4}$ \\
\hline${ }^{60} \mathrm{Co}$ & $1.6 \times 10^{-3}$ \\
\hline${ }^{85} \mathrm{Kr}$ & $8.9 \times 10^{2}$ \\
\hline${ }^{90} \mathrm{Sr}$ & $2.4 \times 10^{-4}$ \\
\hline $91_{Y}$ & $2.9 \times 10^{-4}$ \\
\hline${ }^{95} \mathrm{Zr}$ & $1.7 \times 10^{-3}$ \\
\hline${ }^{96} \mathrm{Nb}$ & $3.0 \times 10^{-3}$ \\
\hline${ }^{106} \mathrm{Ru}$ & $1.0 \times 10^{-3}$ \\
\hline${ }^{125 \mathrm{~m}_{\mathrm{Te}}}$ & $1.4 \times 10^{-5}$ \\
\hline${ }^{127 \mathrm{~m}_{\mathrm{Te}}}$ & $1.3 \times 10^{-5}$ \\
\hline${ }^{129}{ }_{I}$ & $5.0 \times 10^{-5}$ \\
\hline${ }^{134} \mathrm{Cs}$ & $1.8 \times 10^{-2}$ \\
\hline${ }^{137} \mathrm{Cs}$ & $1.2 \times 10^{-2}$ \\
\hline${ }^{144} \mathrm{Ce}$ & $1.8 \times 10^{-3}$ \\
\hline Total & $8.9 \times 10^{2}$ \\
\hline
\end{tabular}

(a) Values taken from Table 4.2.2-2, Reference 2. 
TABLE B.7. Reference Packaging Facility off Gas ${ }^{(a)}$

\begin{tabular}{|c|c|}
\hline Radionuclide & $\begin{array}{l}\text { Release } \\
\text { (Ci/year) }\end{array}$ \\
\hline $3_{H}$ & 1.3 \\
\hline${ }^{14} \mathrm{C}$ & $6.6 \times 10^{-3}$ \\
\hline${ }^{60} \mathrm{Co}$ & $6.3 \times 10^{-4}$ \\
\hline${ }^{85} \mathrm{Kr}$ & $8.1 \times 10^{2}$ \\
\hline${ }^{90} \mathrm{Sr}$ & $9.9 \times 10^{-5}$ \\
\hline${ }^{106} \mathrm{Ru}$ & $2.6 \times 10^{-4}$ \\
\hline${ }^{129} \mathrm{I}$ & $9.9 \times 10^{-4}$ \\
\hline${ }^{134} \mathrm{Cs}$ & $7.2 \times 10^{-3}$ \\
\hline${ }^{137} \mathrm{Cs}$ & $5.4 \times 10^{-3}$ \\
\hline${ }^{144} \mathrm{Ce}$ & $3.9 \times 10^{-4}$ \\
\hline Total & $8.1 \times 10^{2}$ \\
\hline
\end{tabular}

(a)Values taken from Table 4.2.2-2, Reference 2. 


\section{TABLE B.8. Activation Product Inventory in Reference Fuel Assembly Hardware, ${ }^{(a)}$ as a Function of Decay Time, Once-Through Fuel Cycle*}

\begin{tabular}{|c|c|c|c|c|c|c|c|c|c|c|}
\hline \multirow[b]{2}{*}{ Ridionucl ide } & \multicolumn{10}{|c|}{ Ci/MTHM for Various Decay Periods (b) } \\
\hline & $0.5 y r$ & $1.5 \mathrm{yr}$ & $3.5 \mathrm{yr}$ & $6.5 \mathrm{yr}$ & $10^{1}$ yr & $-10^{2} y r$ & $10^{3} y r$ & $10^{4} \mathrm{yr}$ & $10^{5} \mathrm{yr}$ & $=10^{6} \mathrm{yr}$ \\
\hline${ }^{14} \mathrm{C}$ & $5.0 \times 10^{-2}$ & $5.0 \times 10^{-2}$ & $5.0 \times 10^{-2}$ & $5.0 \times 10^{-2}$ & $5.0 \times 10^{-2}$ & $5.0 \times 10^{-2}$ & $5.0 \times 10^{-2}$ & $2.0 \times 10^{-2}$ & $1.0 \times 10^{-7}$ & \\
\hline $35 \mathrm{~s}$ & $8.0 \times 10^{-2}$ & $4.0 \times 10^{-3}$ & $1.0 \times 10^{-5}$ & $2.0 \times 10^{-9}$ & & & & & & \\
\hline${ }^{46} \mathrm{Sc}$ & $8.0 \times 10^{-1}$ & $4.0 \times 10^{-2}$ & $9.0 \times 10^{-5}$ & $1.0 \times 10^{-8}$ & & & & & & \\
\hline${ }^{54} \mathrm{Mn}$ & $3.0 \times 10^{2}$ & $2.0 \times 10^{2}$ & $3.0 \times 10^{1}$ & 2.0 & $8.0 \times 10^{-2}$ & & & & & \\
\hline${ }^{55} \mathrm{Fe}$ & $6.0 \times 10^{3}$ & $4.7 \times 10^{3}$ & $2.5 \times 10^{3}$ & $1.0 \times 10^{3}$ & $4.0 \times 10^{2}$ & $1.0 \times 10^{-8}$ & & & & \\
\hline${ }^{59} \mathrm{Ni}$ & 3.0 & 3.0 & 3.0 & 3.0 & 3.0 & 3.0 & 3.0 & 2.0 & 1.0 & $3.0 \times 10^{-4}$ \\
\hline $63_{\mathrm{Ni}}$ & $4.0 \times 10^{2}$ & $4.0 \times 10^{2}$ & $4.0 \times 10^{2}$ & $4.0 \times 10^{2}$ & $4.0 \times 10^{1}$ & $2.0 \times 10^{2}$ & $2.0 \times 10^{-1}$ & & & \\
\hline${ }^{65} \mathrm{zn}$ & $2.0 \times 10^{1}$ & 6.0 & $8.0 \times 10^{-5}$ & $4.0 \times 10^{-2}$ & $6.0 \times 10^{-4}$ & & & & & \\
\hline${ }^{90} \mathrm{sr}$ & $1.0 \times 10^{-3}$ & $1.0 \times 10^{-3}$ & $1.0 \times 10^{-3}$ & $9.0 \times 10^{-4}$ & $9.0 \times 10^{-4}$ & $9.0 \times 10^{-5}$ & & & & \\
\hline $90_{Y}$ & $1.0 \times 10^{-3}$ & $1.0 \times 10^{-3}$ & $1.0 \times 10^{-3}$ & $9.0 \times 10^{-4}$ & $9.0 \times 10^{-4}$ & $9.0 \times 10^{-5}$ & & & & \\
\hline${ }^{94} \mathrm{Nb}$ & $1.0 \times 10^{-4}$ & $1.0 \times 10^{-4}$ & $1.0 \times 10^{-4}$ & $1.0 \times 10^{-4}$ & $1.0 \times 10^{-4}$ & $1.0 \times 10^{-4}$ & $1.0 \times 10^{-4}$ & $1.0 \times 10^{-4}$ & $3.0 \times 10^{-5}$ & \\
\hline $181_{W}$ & $4.0 \times 10^{-4}$ & $7.0 \times 10^{-5}$ & $2.0 \times 10^{-6}$ & $9.0 \times 10^{-9}$ & & & & & & \\
\hline Total & $1.3 \times 10^{4}$ & $8.7 \times 10^{3}$ & $5.5 \times 10^{3}$ & $3.4 \times 10^{3}$ & $1.8 \times 10^{3}$ & $2.0 \times 10^{2}$ & 3.3 & 2.0 & 1.0 & $5.6 \times 10^{-4}$ \\
\hline $\begin{array}{l}\text { Total thermal } \\
\text { watts }\end{array}$ & $6.8 \times 10^{1}$ & $5.8 \times 10^{1}$ & $4.4 \times 10^{1}$ & $2.9 \times 10^{1}$ & $1.7 \times 10^{1}$ & $3.2 \times 10^{-2}$ & $1.2 \times 10^{-4}$ & $5.9 \times 10^{-5}$ & $4.0 \times 10^{-5}$ & $2.2 \times 10^{-5}$ \\
\hline
\end{tabular}

a. Hardware components are 302-304 stainless steel, Inconel and Nicrobraz-50.

b. Periods are measured from reactor discharge.

*Values taken from Table 3.3.6, Reference 3. 
TABLE B.9. Activation Product Inventory in Reference Zircaloy Cladding Hulls as a Function of Decay Time, Once-Through Fuel Cycle*

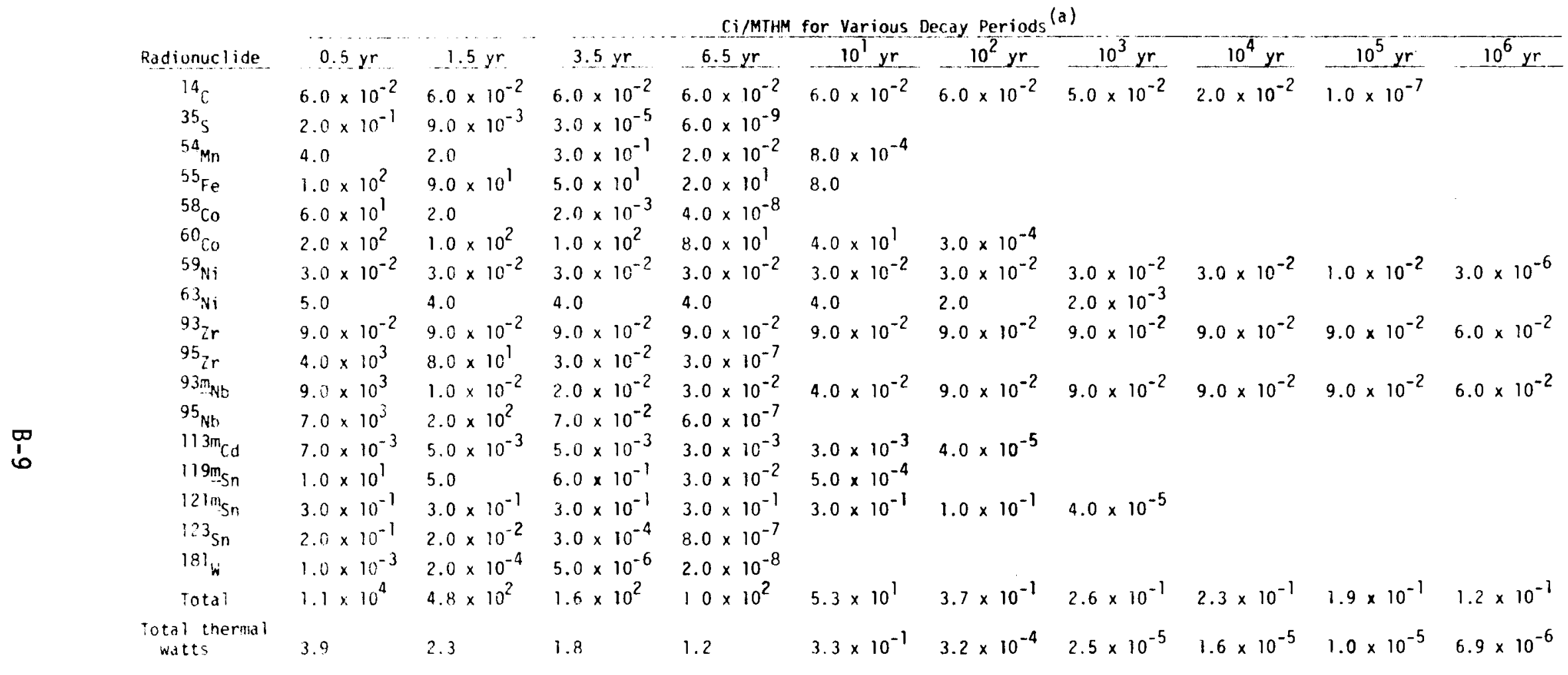

d. Periods are measured from reactor discharge.

*Values taken from Table 3.3.7, Reference 3. 
TABLE B.10. Fission Products in Reference Spent Fuel as a Function of Decay Time, OnceThrough Fuel Cycle*

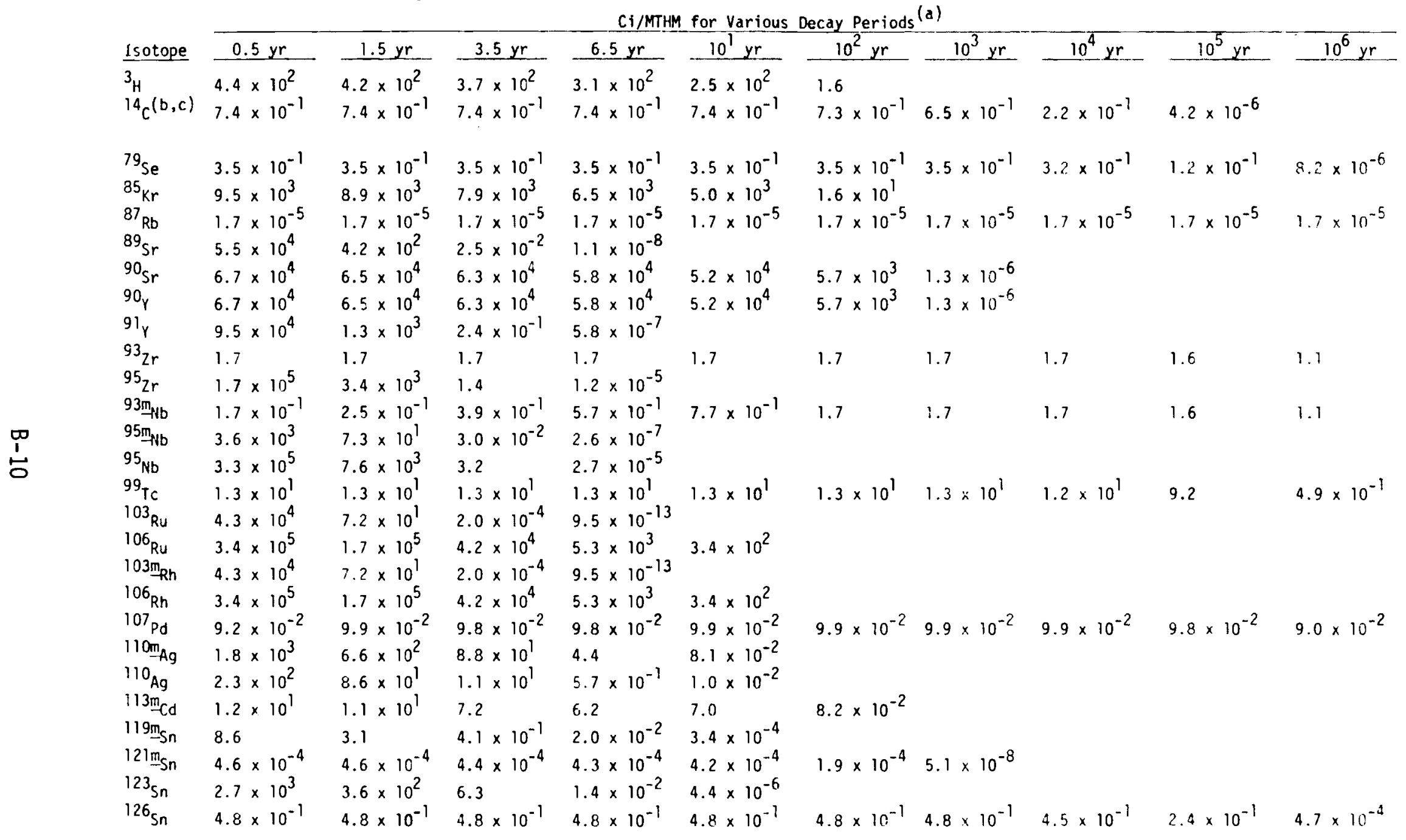

a. Periods are measured frpm reactor discharge.

b. Not a fission product, ${ }^{14} \mathrm{C}$ is formed by neutron activation of ${ }^{14} \mathrm{~N}$ impurity in fuel.

c. Once-through.

*Values taken from Table 3.38, Reference 3. 


\section{TABLE B. 10. (cont'd)}

\begin{tabular}{|c|c|c|c|c|c|c|c|c|c|c|}
\hline & & & & $\mathrm{Ci} / \mathrm{MTHM}$ & for various & Decay Periods & (a) & & & \\
\hline Isotope & $0.5 \mathrm{yr}$ & $1.5 \mathrm{yr}$ & $3.5 \mathrm{yr}$ & $6.5 \mathrm{yr}$ & $10^{1} \mathrm{yr}$ & $10^{2} \mathrm{yr}$ & $10^{3} \mathrm{yr}$ & $10^{4} \mathrm{yr}$ & $10^{5} \mathrm{yr}$ & $10^{6} \mathrm{yr}$ \\
\hline${ }^{124} 4_{S b}$ & $4.3 \times 10^{1}$ & $6.4 \times 10^{-1}$ & $1.4 \times 10^{-4}$ & $4.4 \times 10^{-10}$ & & & & & & \\
\hline $125 \mathrm{Sb}$ & $6.8 \times 10^{3}$ & $5.3 \times 10^{3}$ & $3.1 \times 10^{3}$ & $1.4 \times 10^{3}$ & $5.3 \times 10^{2}$ & $4.9 \times 10^{-8}$ & & & & \\
\hline $126 m_{S b}$ & $4.8 \times 10^{-1}$ & $4.8 \times 10^{-1}$ & $4.8 \times 10^{-1}$ & $4.8 \times 10^{-1}$ & $4.8 \times 10^{-1}$ & $4.8 \times 10^{-1}$ & $4.8 \times 10^{-1}$ & $4.5 \times 10^{-1}$ & $2.4 \times 10^{-1}$ & $4.7 \times 10^{-4}$ \\
\hline $126_{\mathrm{sb}}$ & $4.8 \times 10^{-1}$ & $4.8 \times 10^{-1}$ & $4.8 \times 10^{-1}$ & $4.8 \times 10^{-1}$ & $4.8 \times 10^{-1}$ & $4.8 \times 10^{-1}$ & $4.8 \times 10^{-1}$ & $4.5 \times 10^{-1}$ & $2.4 \times 10^{-1}$ & $4.7 \times 10^{-4}$ \\
\hline $123 \underline{m}_{T e}$ & $1.6 \times 10^{-1}$ & $1.8 \times 10^{-2}$ & $2.3 \times 10^{-4}$ & $3.5 \times 10^{-7}$ & & & & & & \\
\hline $125 \mathrm{mr}$ & $2.8 \times 10^{3}$ & $2.2 \times 10^{3}$ & $1.3 \times 10^{3}$ & $6.0 \times 10^{2}$ & $2.2 \times 10^{2}$ & $2.0 \times 10^{-8}$ & & & & \\
\hline $127 \mathrm{~m}$ Te & $4.2 \times 10^{3}$ & $4.2 \times 10^{2}$ & 4.0 & $3.8 \times 10^{-3}$ & $3.5 \times 10^{-7}$ & & & & & \\
\hline${ }^{127} \mathrm{Te}$ & $4.2 \times 10^{3}$ & $4.1 \times 10^{2}$ & 3.9 & $3.7 \times 10^{-3}$ & $3.5 \times 10^{-7}$ & & & & & \\
\hline $129_{1}$ & $3.3 \times 10^{-2}$ & $3.3 \times 10^{-2}$ & $3.3 \times 70^{-2}$ & $3.3 \times 10^{-2}$ & $3.3 \times 10^{-2}$ & $3.3 \times 10^{-2}$ & $3.3 \times 10^{-2}$ & $3.3 \times 10^{-2}$ & $3.3 \times 10^{-2}$ & $3.3 \times 10^{-2}$ \\
\hline${ }^{34} \mathrm{cs}$ & $1.7 \times 10^{5}$ & $1.2 \times 10^{5}$ & $6.0 \times 10^{4}$ & $2.2 \times 10^{4}$ & $5.7 \times 10^{3}$ & & & & & \\
\hline${ }^{135} \mathrm{Cs}$ & $2.7 \times 10^{-1}$ & $2.7 \times 10^{-1}$ & $2.7 \times 10^{-1}$ & $2.7 \times 10^{-1}$ & $2.7 \times 10^{-1}$ & $2.7 \times 10^{-1}$ & $2.7 \times 10^{-1}$ & $2.7 \times 10^{-1}$ & $2.6 \times 10^{-1}$ & $2.1 \times 10^{-1}$ \\
\hline${ }^{137} \mathrm{Cs}$ & $9.4 \times 10^{4}$ & $9.2 \times 10^{4}$ & $8.8 \times 10^{4}$ & $8.2 \times 10^{4}$ & $7.5 \times 10^{4}$ & $9.4 \times 10^{3}$ & $8.8 \times 10^{-6}$ & & & \\
\hline $137 m_{B a}$ & $8.8 \times 10^{4}$ & $8.6 \times 10^{4}$ & $8.2 \times 10^{4}$ & $7.8 \times 10^{4}$ & $7.0 \times 10^{4}$ & $8.8 \times 10^{3}$ & $8.2 \times 10^{-6}$ & & & \\
\hline${ }^{141} \mathrm{Ce}$ & $2.4 \times 10^{4}$ & 9.7 & $1.6 \times 10^{-6}$ & $1.1 \times 10^{-16}$ & & & & & & \\
\hline${ }^{144} \mathrm{Ce}$ & $6.1 \times 10^{5}$ & $2.5 \times 10^{5}$ & $4.2 \times 10^{4}$ & $2.9 \times 10^{3}$ & $8.2 \times 10^{1}$ & & & & & \\
\hline${ }^{144} \mathrm{Pr}$ & $6.1 \times 10^{5}$ & $2.4 \times 10^{5}$ & $4.2 \times 10^{4}$ & $2.9 \times 10^{3}$ & $8.2 \times 10^{1}$ & & & & & \\
\hline${ }^{147} P_{\mathrm{Pm}}$ & $9.0 \times 10^{4}$ & $6.9 \times 10^{4}$ & $4.1 \times 10^{4}$ & $1.9 \times 10^{4}$ & $6.4 \times 10^{3}$ & $2.9 \times 10^{-7}$ & & & & \\
\hline $148 m_{P_{m}}$ & $1.7 \times 10^{3}$ & 4.1 & $2.4 \times 10^{-5}$ & $3.4 \times 10^{-13}$ & & & & & & \\
\hline${ }^{143} 3_{\mathrm{Pm}}$ & $1.4 \times 10^{2}$ & $3.3 \times 10^{-1}$ & $1.9 \times 10^{-6}$ & $2.7 \times 10^{-14}$ & & & & & & \\
\hline${ }^{151_{\mathrm{Sm}}}$ & $1.2 \times 10^{3}$ & $1.1 \times 10^{3}$ & $1.1 \times 10^{3}$ & $1.1 \times 10^{3}$ & $1.1 \times 10^{3}$ & $5.2 \times 10^{2}$ & $4.0 \times 10^{-1}$ & & & \\
\hline $152_{\mathrm{fu}}$ & $1.3 \times 10^{1}$ & $1.2 \times 10^{1}$ & $1.1 \times 10^{1}$ & 9.0 & 7.1 & $3.9 \times 10^{-2}$ & & & & \\
\hline $154 \mathrm{EL}$ & $5.8 \times 10^{3}$ & $5.5 \times 10^{3}$ & $5.0 \times 10^{3}$ & $4.4 \times 10^{3}$ & $3.7 \times 10^{3}$ & $7.6 \times 10^{1}$ & & & & \\
\hline $155_{E U}$ & $5.7 \times 10^{3}$ & $3.9 \times 10^{3}$ & $1.8 \times 10^{3}$ & $5.7 \times 10^{2}$ & $1.2 \times 10^{2}$ & & & & & \\
\hline${ }^{153} \mathrm{Gd}$ & $1.9 \times 10^{1}$ & 6.6 & $8.8 \times 10^{-1}$ & $3.5 \times 10^{-2}$ & & & & & & \\
\hline${ }^{160} \mathrm{~Tb}$ & $1.8 \times 10^{2}$ & 5.2 & $4.6 \times 10^{-3}$ & $1.2 \times 10^{-7}$ & & & & & & \\
\hline $166 m_{10}$ & $5.4 \times 10^{-4}$ & $5.4 \times 10^{-4}$ & $5.2 \times 10^{-4}$ & $5.2 \times 10^{-4}$ & $5.4 \times 10^{-4}$ & $5.1 \times 10^{-4}$ & $3.0 \times 10^{-4}$ & $1.7 \times 10^{-6}$ & & \\
\hline Total & $3.3 \times 10^{6}$ & $1.4 \times 10^{6}$ & $5.9 \times 10^{5}$ & $3.5 \times 10^{5}$ & $2.7 \times 10^{5}$ & $3.0 \times 10^{4}$ & $1.9 \times 10^{1}$ & $1.8 \times 10^{1}$ & $1.4 \times 10^{1}$ & 2.9 \\
\hline $\begin{array}{l}\text { Total } \\
\text { Thermal } \\
\text { Watts }\end{array}$ & $1.5 \times 10^{4}$ & $6.3 \times 10^{3}$ & $2.5 \times 10^{3}$ & $1.2 \times 10^{3}$ & $8.9 \times 10^{2}$ & $9.2 \times 10^{1}$ & $2.0 \times 10^{-2}$ & $1.9 \times 10^{-2}$ & $1.2 \times 10^{-2}$ & $7.8 \times 10^{-4}$ \\
\hline
\end{tabular}

a. Periods are measured from reactor discharge. 
TABLE B.11. Actinides and Daughters in Reference Spent Fuel as a Function of Decay Time, Once-Through Fuel Cycle*

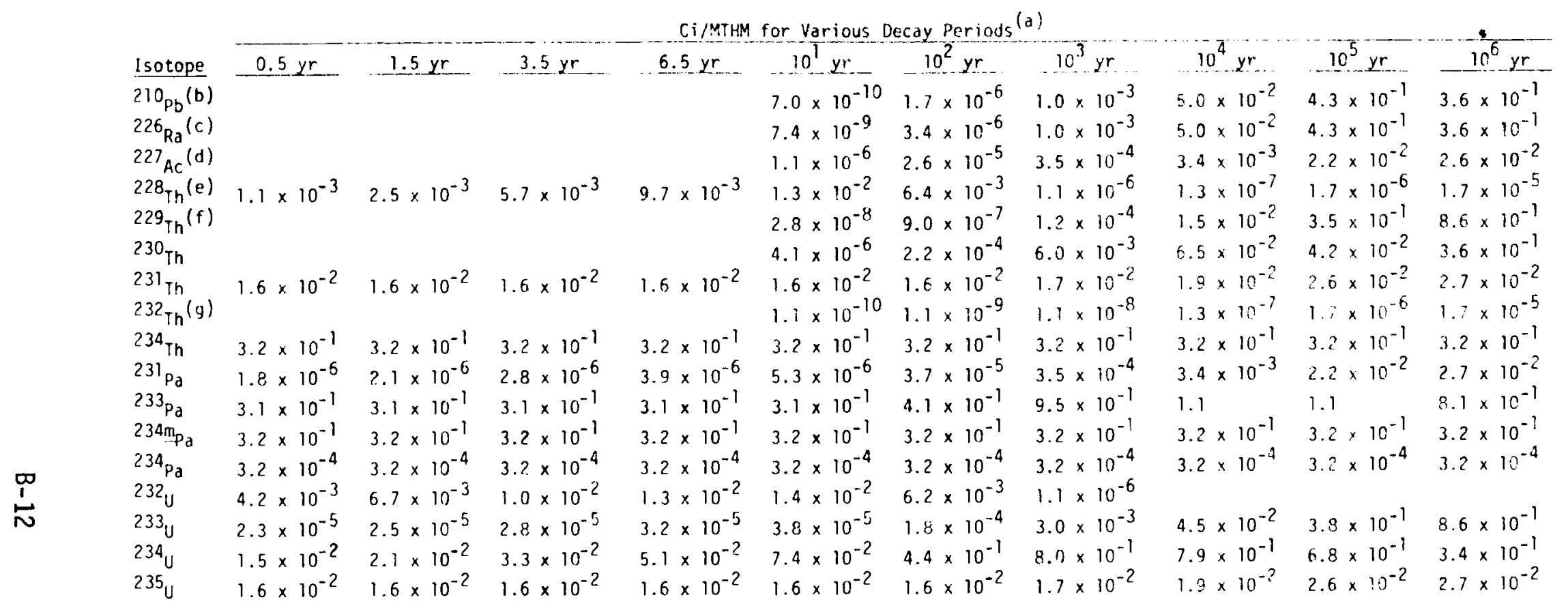

-..............

a. Periods are measured from reactor discharge.

b. Activities of $210_{\mathrm{Bi}}$ and $210_{\mathrm{PO}}$ are the same as ${ }^{210} \mathrm{~Pb}$.

c. Activities of ${ }^{222} \mathrm{Rn}, 21{ }^{2} \mathrm{Po}, 214 \mathrm{~Pb}, 214 \mathrm{Bi}$, and ${ }^{214} \mathrm{Po}$ are the same as ${ }^{226} \mathrm{Ra}$.

c. Activities of ${ }^{227} \mathrm{Th},{ }^{273} \mathrm{Ra}, 219 \mathrm{Rn}, 21{ }^{\mathrm{PO}},{ }^{211} \mathrm{~Pb}, 211_{\mathrm{Bi}}$ and $207 \mathrm{Tl}$ are the same as $227 \mathrm{AC}$

e. Activities of ${ }^{224} \mathrm{Ra},{ }^{220} \mathrm{Rn}, 216_{\mathrm{Po}}, 212 \mathrm{~Pb}, 212 \mathrm{Bi}$ are the same as ${ }^{228} \mathrm{Th},{ }^{208} \mathrm{Tl}$ is $36{ }^{2}$ of ${ }^{228} \mathrm{Th}$ and $212 \mathrm{Po}$ is 64 if $228 \mathrm{Th}$.

f. Activities of ${ }^{225} \mathrm{Ra}, 225 \mathrm{Ac}, 221 \mathrm{Fr}, 217 \mathrm{At}, 213 \mathrm{Bi}$ and ${ }^{209} \mathrm{~Pb}$ are the same as $229 \mathrm{Th}$, ${ }^{209} \mathrm{Tl}$ is 9 . of ${ }^{229} \mathrm{Th}$ and ${ }^{213} \mathrm{Fo}$ is 91 of ${ }^{229} \mathrm{Th}$.

9. Activities of ${ }^{228} \mathrm{Ra}$ and ${ }^{228} \mathrm{AC}$ are the same as ${ }^{232} \mathrm{Th}$.

*Values taken from Table 3.3.10, Reference 3 . 


\section{TABLE B.11. (cont'd)}

\begin{tabular}{|c|c|c|c|c|c|c|c|c|c|c|c|}
\hline & & & & & $\mathrm{Ci} / \mathrm{MTH}$ & for Various & lecay Periods & & & & \\
\hline & Isotor: & $0.5 \mathrm{yr}$ & $1.5 \mathrm{yr}$ & $3.5 \mathrm{yr}$ & $6.5 y r$ & $10^{1} \mathrm{yr}$ & $10^{2} y r$ & $10^{3} y r$ & $10^{4} y r$ & $10^{5} \mathrm{yr}$ & $10^{6} \mathrm{yr}$ \\
\hline & $236_{u}$ & $2.2 \times 10^{-1}$ & $2.2 \times 10^{-1}$ & $2.2 \times 10^{-1}$ & $2.2 \times 10^{-1}$ & $2.2 \times 10^{-1}$ & $2.2 \times 10^{-1}$ & $2.4 \times 10^{-1}$ & $3.1 \times 10^{-1}$ & $3.5 \times 10^{-1}$ & $3.4 \times 10^{-1}$ \\
\hline & $237_{U}^{\circ}$ & 2.8 & 2.7 & 2.4 & 2.1 & 1.7 & $2.6 \times 10^{-2}$ & $4.1 \times 10^{-6}$ & $1.9 \times 10^{-6}$ & $1.0 \times 10^{-9}$ & \\
\hline & $238_{U}$ & $3.2 \times 10^{-1}$ & $3.2 \times 10^{-1}$ & $3.2 \times 10^{-1}$ & $3.2 \times 10^{-1}$ & $3.2 \times 10^{-1}$ & $3.2 \times 10^{-1}$ & $3.2 \times 10^{-1}$ & $3.2 \times 10^{-1}$ & $3.2 \times 10^{-1}$ & $3.2 \times 10^{-1}$ \\
\hline & ${ }^{237} \mathrm{~Np}$ & $3.1 \times 10^{-1}$ & $3.1 \times 10^{-1}$ & $3.1 \times 10^{-1}$ & $3.1 \times 10^{-1}$ & $3.1 \times 10^{-1}$ & $4.1 \times 10^{-1}$ & $9.5 \times 10^{-1}$ & 1.1 & 1.1 & $8.1 \times 10^{-1}$ \\
\hline & $239 \mathrm{~Np}$ & $1.4 \times 10^{1}$ & $1.4 \times 10^{1}$ & $1.4 \times 10^{1}$ & $1.4 \times 10^{1}$ & $1.4 \times 10^{1}$ & $1.4 \times 10^{1}$ & $1.3 \times 10^{1}$ & 5.7 & $1.6 \times 10^{-3}$ & $1.2 \times 10^{-7}$ \\
\hline & $236 \mathrm{pu}_{\mathrm{u}}$ & $2.9 \times 10^{-1}$ & $2.3 \times 10^{-1}$ & $1.4 \times 10^{-1}$ & $6.8 \times 10^{-2}$ & $2.6 \times 10^{-2}$ & & & & & \\
\hline & ${ }^{238} \mathrm{Pu}$ & $2.1 \times 10^{3}$ & $2.1 \times 10^{3}$ & $2.1 \times 10^{3}$ & $2.1 \times 10^{3}$ & $2.0 \times 10^{3}$ & $1.0 \times 10^{3}$ & 1.1 & & & \\
\hline & ${ }^{239} \mathrm{Pu}$ & $2.9 \times 10^{2}$ & $2.9 \times 10^{2}$ & $2.9 \times 10^{2}$ & $2.9 \times 10^{2}$ & $2.9 \times 10^{2}$ & $2.9 \times 10^{2}$ & $2.8 \times 10^{2}$ & $2.2 \times 10^{2}$ & $1.7 \times 10^{1}$ & $1.2 \times 10^{-7}$ \\
\hline & $240 \mathrm{Pu}$ & $4.5 \times 10^{2}$ & $4.5 \times 10^{2}$ & $4.5 \times 10^{2}$ & $4.5 \times 10^{2}$ & $4.5 \times 10^{2}$ & $4.5 \times 10^{2}$ & $4.1 \times 10^{2}$ & $1.6 \times 10^{2}$ & $1.6 \times 10^{-2}$ & $1.3 \times 10^{-9}$ \\
\hline & $241 \mathrm{Pu}$ & $1.1 \times 10^{5}$ & $1.1 \times 10^{5}$ & $9.2 \times 10^{4}$ & $8.4 \times 10^{4}$ & $6.9 \times 10^{4}$ & $1.0 \times 10^{3}$ & $1.7 \times 10^{-1}$ & $7.8 \times 10^{-2}$ & $4.1 \times 10^{-5}$ & \\
\hline & ${ }^{242} p_{u}$ & 1.6 & 1.6 & 1.6 & 1.6 & 1.6 & 1.6 & 1.6 & 1.6 & 1.4 & $2.6 \times 10^{-1}$ \\
\hline & ${ }^{241} \mathrm{Am}$ & $2.0 \times 10^{2}$ & $3.7 \times 10^{2}$ & $6.9 \times 10^{2}$ & $1.1 \times 10^{3}$ & $1.6 \times 10^{3}$ & $3.5 \times 10^{3}$ & $8.3 \times 10^{2}$ & $7.8 \times 10^{-2}$ & $4.1 \times 10^{-5}$ & \\
\hline & $242 m_{A m}$ & $1.1 \times 10^{1}$ & $1.1 \times 10^{1}$ & $1.1 \times 10^{1}$ & $1.0 \times 10^{1}$ & $1.0 \times 10^{1}$ & 6.9 & $1.1 \times 10^{-1}$ & & & \\
\hline & & $1.1 \times 10^{1}$ & $1.1 \times 10^{1}$ & $1.1 \times 10^{1}$ & $1.0 \times 10^{1}$ & $1.0 \times 10^{1}$ & 6.9 & $1.1 \times 10^{-1}$ & & & \\
\hline & ${ }^{243} \mathrm{Am}$ & $1.4 \times 10^{1}$ & $1.4 \times 10^{1}$ & $1.4 \times 10^{1}$ & $1.4 \times 10^{1}$ & $1.4 \times 10^{1}$ & $1.4 \times 10^{1}$ & $1.3 \times 10^{1}$ & 5.7 & $1.6 \times 10^{-3}$ & $1.2 \times 10^{-7}$ \\
\hline & ${ }^{242} \mathrm{~cm}$ & $1.7 \times 10^{4}$ & $3.6 \times 10^{3}$ & $1.7 \times 10^{2}$ & $1.0 \times 10^{1}$ & 8.5 & 5.6 & $9.3 \times 10^{-2}$ & & & \\
\hline & $243 \mathrm{~cm}$ & 4.0 & 3.9 & 3.8 & 3.5 & 3.2 & $4.6 \times 10^{-1}$ & $1.6 \times 10^{-9}$ & & & \\
\hline & ${ }^{244} \mathrm{~cm}$ & $1.3 \times 10^{3}$ & $1.3 \times 10^{3}$ & $1.2 \times 10^{3}$ & $1.0 \times 10^{3}$ & $9.0 \times 10^{2}$ & $2.9 \times 10^{1}$ & & & & \\
\hline & $245 \mathrm{~cm}$ & $1.8 \times 10^{-1}$ & $1.8 \times 10^{-1}$ & $1.8 \times 10^{-1}$ & $1.8 \times 10^{-1}$ & $1.8 \times 10^{-1}$ & $1.8 \times 10^{-1}$ & $1.7 \times 10^{-1}$ & $7.8 \times 10^{-2}$ & $4.1 \times 10^{-5}$ & \\
\hline & ${ }^{246} \mathrm{~cm}$ & $3.5 \times 10^{-2}$ & $3.5 \times 10^{-2}$ & $3.4 \times 10^{-2}$ & $3.4 \times 10^{-2}$ & $3.5 \times 10^{-2}$ & $3.4 \times 10^{-2}$ & $3.0 \times 10^{-2}$ & $7.9 \times 10^{-3}$ & $1.4 \times 10^{-8}$ & \\
\hline & $249 B K$ & $1.1 \times 10^{-3}$ & $5.0 \times 10^{-4}$ & $9.9 \times 10^{-5}$ & $8.9 \times 10^{-6}$ & $3.5 \times 10^{-7}$ & & & & & \\
\hline & ${ }^{249} \mathrm{Cf}$ & $1.9 \times 10^{-6}$ & $3.4 \times 10^{-6}$ & $4.4 \times 10^{-6}$ & $4.6 \times 10^{-6}$ & $4.6 \times 10^{-6}$ & $3.8 \times 10^{-6}$ & $6.5 \times 10^{-7}$ & & & \\
\hline & ${ }^{250} \mathrm{Cf}$ & $1.7 \times 10^{-5}$ & $1.6 \times 10^{-5}$ & $1.4 \times 10^{-5}$ & $1.2 \times 10^{-5}$ & $9.9 \times 10^{-6}$ & $8.4 \times 10^{-8}$ & & & & \\
\hline & ${ }^{252} \mathrm{Cf}$ & $2.0 \times 10^{-5}$ & $1.5 \times 10^{-5}$ & $9.0 \times 10^{-6}$ & $4.1 \times 10^{-6}$ & $1.4 \times 10^{-6}$ & & & & & \\
\hline & Total & $1.3 \times 10^{5}$ & $1.1 \times 10^{5}$ & $1.0 \times 10^{5}$ & $8.9 \times 10^{4}$ & $7.5 \times 10^{4}$ & $6.3 \times 10^{3}$ & $1.6 \times 10^{3}$ & $4.0 \times 10^{2}$ & $3.1 \times 10^{1}$ & $1.5 \times 10^{1}$ \\
\hline & $\begin{array}{l}\text { Total } \\
\text { Thermal }\end{array}$ & & & & & & & & & & \\
\hline & Watts & $7.7 \times 10^{2}$ & $2.9 \times 10^{2}$ & $1.7 \times 10^{2}$ & $1.7 \times 10^{2}$ & $1.8 \times 10^{2}$ & $1.7 \times 10^{2}$ & $5.0 \times 10^{1}$ & $1.2 \times 10^{1}$ & $8.3 \times 10^{-1}$ & $3.5 \times 10^{-1}$ \\
\hline
\end{tabular}

a. Periods are measured from reactor discharge. 


\section{REFERENCES}

1. U.S. Nuclear Regulatory Commission, Final Generic Environmental Statement on the Use of Recycle Plutonium in Mixed Oxide Fuel in Light Water Cooled Reactor. NUREG-0002, August 1976.

2. U.S. Department of Energy, Environmental Aspects of Commercial Radioactive Waste Management. DOE/ET-0029, May 1979.

3. U.S. Department of Energy, Technology for Commercial Radioactive Waste Management. DOE/ET-0028, May 1979. 
APPENDIX C

SYSTEM DEFINITION OF THE

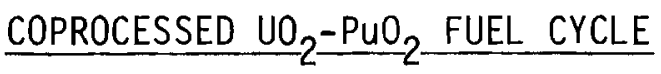

S. E. Lyke

J. W. Voss 
APPENDIX C

SYSTEM DEFINITION OF THE

${ }_{\mathrm{COPROCESSED} \mathrm{UO}}-\mathrm{PUO}_{2}$ FUEL CYCLE

A variety of fuel cycles are being studied at present, partly as a response to the Nonproliferation Alternative Systems Assessment Program (NASAP). This section discusses the coprocessed $\mathrm{UO}_{2}-\mathrm{PuO}_{2}$ fuel cycle.

\section{C.1 REFERENCE FUEL CYCLE}

The reference coprocessed $\mathrm{UO}_{2}-\mathrm{PuO}_{2}$ fuel cycle offers many of the safeguards present in the once-through, denatured and spiked fuel cycle. As hypothesized, the spent nuclear fuel would enter a separations facility and be sheared and dissolved. In the separations process only part of the uranium, fission products, and other actinides would be separated from the plutonium. Thus, a pure plutonium stream would never exist, blocking any opportunity to steal such material. The product would be denatured with partially enriched uranium, and spiked with some fission products and actinides. The product of the separations plant would be a $\mathrm{UO}_{2}-\mathrm{PuO}_{2}$ powder, contaminated with fission production and actinides. This concept in general is not new al though the exact chemical flowsheet is novel. Coprocessing is discussed in several reports. $(2,3,4)$

The following sections detail the fuel cycle analysis performed to determine the radioisotopics of the reference coprocessed $\mathrm{UO}_{2}-\mathrm{PuO}_{2}$ fuel cycle. The computer code ORIGEN ${ }^{(5)}$ was used to perform burnup calculations.

\section{C.1.1 Fuel Cycle Data}

The fuel cycle considered is shown in Figure C.1. Burnup and separations calculations were performed for the first burn and separation cycle of fuel. Burnup calculations were performed for the second recycle of the coprocessed fuel. Waste isotopics are based on separations plant receipt of the second 


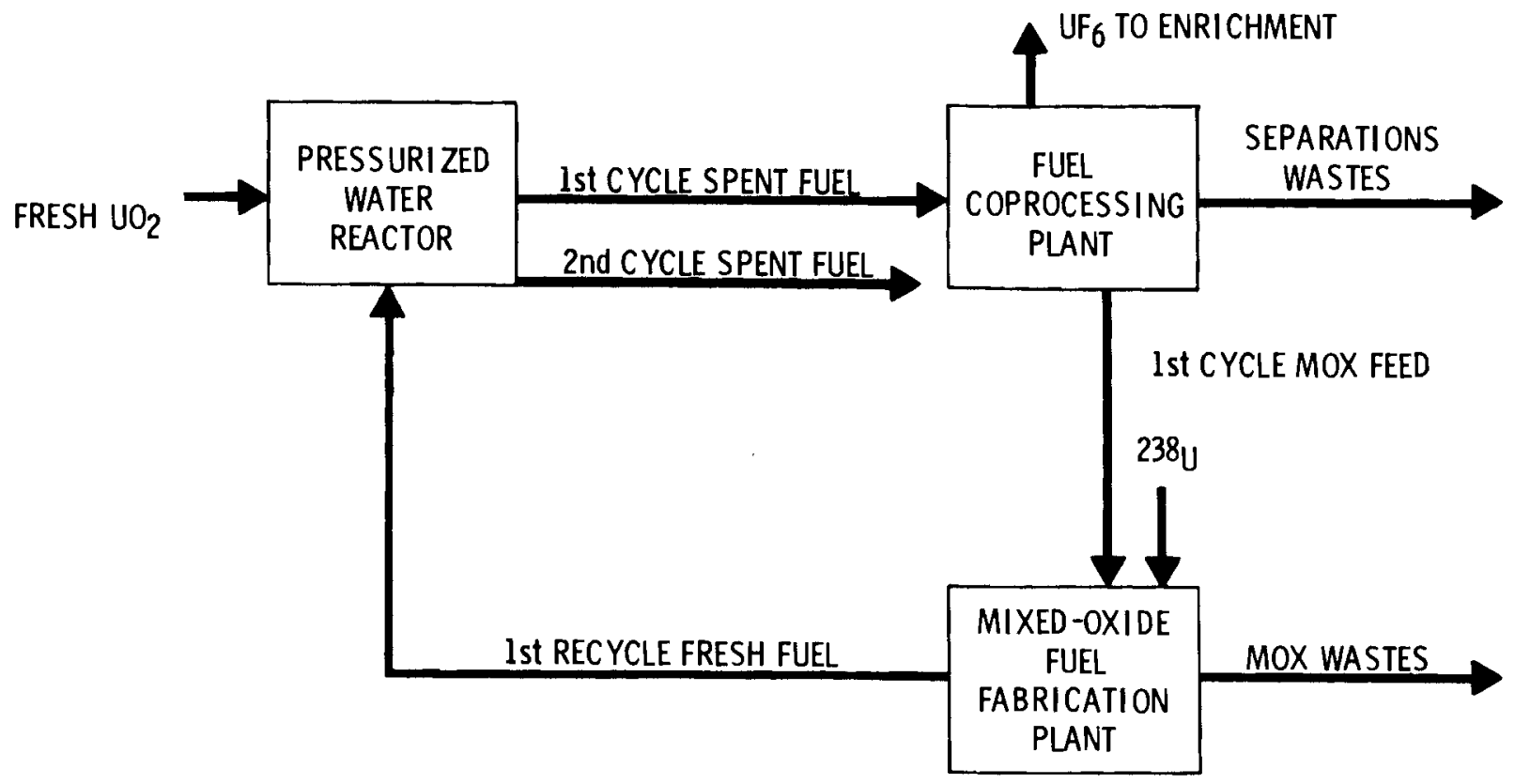

FIGURE C.1. Coprocessed $\mathrm{UO}_{2}-\mathrm{PuO}_{2}$ Fuel Cycle

cycle spent fuel. The impact of further recycles would be to build up fission product and actinide radioactivity concentration per unit heavy metal mass of fuel. Basic input data to the ORIGEN calculations are listed in Table C.1.

\section{C.1.2 Isotopics}

This section lists the radioisotopic inventories of 1 MTHM of the second recycle, coprocessed fuel. This material is assumed to be reference for all waste management calculations. Tables $C .2$ and $C .3$ list, respectively the heavy metal and fission product radionuclides per MTHM of spent fuel, as calculated using ORIGEN. Table C.4 lists fuel element hulls and hardware radionuclide constituents in spent fuel. (6) A11 isotopics are listed for a fuel decay period of 550 days out-of-reactor. 
TABLE C.1. Input Data to Burnup and Separations Calculations Using Origen

PRESSURIZED WIATER REACTOR

$\operatorname{THERM}(a)$

$\operatorname{RES}(a)$

FAST (a)

0.79

Specific Power

Burnup Period

Decay before Separation

3.95

29.0 MW/MTHM

1095 days

550 days

FUEL COPROCESSING PLANT

Time to Separate

550 days

Fraction of Input

RECYCLED

$\mathrm{Pu}$

0.9929

$\mathrm{Np}$

0.035

U

0.1392

$\mathrm{Ru} / \mathrm{Rh}$

0.042

$\mathrm{Zr} / \mathrm{Nb}(\mathrm{b})$

0.047

${ }^{3} \mathrm{H},{ }^{14} \mathrm{C}, \mathrm{I}, \mathrm{Xe}, \mathrm{Kr}$

0

All Others

0.005

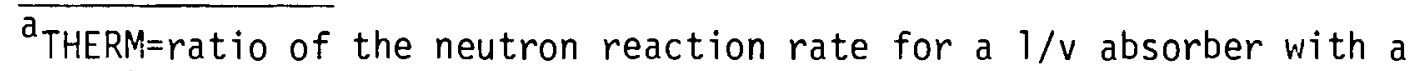
population of neutrons having a Maxwell-Boltzman distribution of energies of absolute temperature, $T$, to the reaction rate with $2200 \mathrm{~m} / \mathrm{sec}$ neutrons; RES=ratio of the resonance flux per unit lethargy to the thermal neutron flux; FAST=ratio of flux above $1 \mathrm{MeV}$ to the fraction of the fission spectrum above $\mathrm{l} \mathrm{MeV}$, divided by the thermal neutron flux.

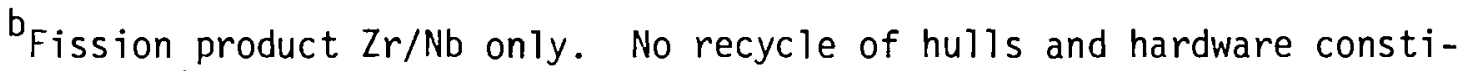
tuents is considered. 
TABLE C.2. Heavy Metal Radionuclides In Spent, Coprocessed Fuel (a)

\begin{tabular}{|c|c|c|c|}
\hline Radioisotope & $\begin{array}{l}\text { Activity } \\
\text { (Ci/MTHM) }\end{array}$ & Radioisotope & $\begin{array}{l}\text { Activity } \\
\text { (Ci/MTHM) } \\
\end{array}$ \\
\hline T1-208 & $6.6 \times 10^{-3}$ & $N p-239$ & $2.1 \times 10^{2}$ \\
\hline$P b-212$ & $1.8 \times 10^{-2}$ & $\mathrm{Pu}-236$ & $5.4 \times 10^{-1}$ \\
\hline $\mathrm{Bi}-212$ & $1.8 \times 10^{-2}$ & $\mathrm{Pu}-238$ & $1.2 \times 10^{4}$ \\
\hline Po-212 & $1.2 \times 10^{-2}$ & $P u-239$ & $4.4 \times 10^{2}$ \\
\hline Po-216 & $1.8 \times 10^{-2}$ & $\mathrm{Pu}-240$ & $1.3 \times 10^{3}$ \\
\hline$R n-220$ & $1.8 \times 10^{-2}$ & $\mathrm{Pu}-241$ & $4.0 \times 10^{5}$ \\
\hline $\mathrm{Ra}-224$ & $1.8 \times 10^{-2}$ & $\mathrm{Pu}-242$ & $1.1 \times 10^{1}$ \\
\hline Th-228 & $1.8 \times 10^{-2}$ & $A m-241$ & $1.8 \times 10^{3}$ \\
\hline Th-231 & $5.0 \times 10^{-3}$ & $A m-242 m$ & $9.6 \times 10^{1}$ \\
\hline$T h-234$ & $3.1 \times 10^{-1}$ & $A m-242$ & $9.6 \times 10^{1}$ \\
\hline $\mathrm{Pa}-233$ & $2.6 \times 10^{-1}$ & $A m-243$ & $2.1 \times 10^{2}$ \\
\hline $\mathrm{Pa}-234 \mathrm{~m}$ & $3.1 \times 10^{-1}$ & $\mathrm{Cm}-242$ & $2.8 \times 10^{4}$ \\
\hline $\mathrm{Pa}-234$ & $3.1 \times 10^{-4}$ & $\mathrm{Cm}-243$ & $3.5 \times 10^{1}$ \\
\hline$U-232$ & $3.1 \times 10^{-2}$ & $\mathrm{Cm}-244$ & $3.4 \times 10^{4}$ \\
\hline$U-233$ & $1.8 \times 10^{-5}$ & $\mathrm{Cm}-245$ & 5.7 \\
\hline$U-234$ & $1.3 \times 10^{-1}$ & $\mathrm{Cm}-246$ & 1.2 \\
\hline$U-235$ & $5.0 \times 10^{-3}$ & $\mathrm{Cm}-248$ & $1.3 \times 10^{-5}$ \\
\hline$U-236$ & $1.9 \times 10^{-1}$ & $B k-249$ & $1.6 \times 10^{-2}$ \\
\hline$U-237$ & $1.0 \times 10^{1}$ & $c f-249$ & $1.1 \times 10^{-4}$ \\
\hline$U-238$ & $3.1 \times 10^{-1}$ & $c f-250$ & $4.8 \times 10^{-4}$ \\
\hline \multirow[t]{2}{*}{$N p-237$} & $2.6 \times 10^{-1}$ & $c f-252$ & $5.4 \times 10^{-4}$ \\
\hline & & TOTAL & $4.8 \times 10^{5}$ \\
\hline
\end{tabular}

(a) Values less than $1.0 \times 10^{-5}$ Curies/MTHM have been ignored. Radioactivities for decay times of 18 months out-of-reactor. 
TABLE C.3. Fission Product Radionuclides In Spent, Coprocessed Fuel (a)

\begin{tabular}{|c|c|c|c|c|c|}
\hline Radioisotope & $\begin{array}{l}\text { Activity } \\
\text { (Ci/MTHM) }\end{array}$ & Radioisotope & $\begin{array}{l}\text { Activity } \\
\text { (Ci/MTHM) }\end{array}$ & Radioisotope & (Ci/MTHM) \\
\hline $\mathrm{H}-3$ & $5.6 \times 10^{2}$ & $\mathrm{Sn}-121 \mathrm{~m}$ & $6.0 \times 10^{-4}$ & & \\
\hline Se-79 & $3.3 \times 10^{-1}$ & Sn-123 & $5.1 \times 10^{2}$ & Pm- 147 & $8.5 \times 10^{4}$ \\
\hline \multirow[t]{2}{*}{$\mathrm{Kr}-85$} & $6.0 \times 10^{3}$ & $\mathrm{Te}-123 \mathrm{~m}$ & $1.8 \times 10^{-2}$ & Pm-148m & 5.1 \\
\hline & & $S b-124$ & 1.1 & Pm- 148 & $4.1 \times 10^{-1}$ \\
\hline $\mathrm{Rb}-87$ & $1.1 \times 10^{-5}$ & & & Sm-151 & $1.6 \times 10^{3}$ \\
\hline$S r-89$ & $3.1 \times 10^{2}$ & $S b-125$ & $9.5 \times 10^{3}$ & Eu-152 & $2.4 \times 10^{1}$ \\
\hline Sr-90 & $4.3 \times 10^{4}$ & $\mathrm{Te}-125 \mathrm{~m}$ & $4.0 \times 10^{3}$ & Gd-153 & 8.0 \\
\hline$Y-90$ & $4.3 \times 10^{4}$ & $S n-126$ & $9.3 \times 10^{-1}$ & Eu-154 & $6.9 \times 10^{3}$ \\
\hline$Y-91$ & $9.9 \times 10^{2}$ & $S b-126 m$ & $9.3 \times 10^{-1}$ & Eu-155 & $5.2 \times 10^{3}$ \\
\hline$Z r-93$ & 1.8 & $S b-126$ & $9.2 \times 10^{-1}$ & & \\
\hline$N b-93 m$ & $3.4 \times 10^{-1}$ & $\mathrm{Te}-127 \mathrm{~m}$ & $5.7 \times 10^{2}$ & Tb-160 & 9.8 \\
\hline $\mathrm{Zr}-95$ & $3.3 \times 10^{3}$ & Te-127 & $5.7 \times 10^{2}$ & Ho $-166 \mathrm{~m}$ & $8.0 \times 10^{-3}$ \\
\hline$N b-95 m$ & $7.1 \times 10^{1}$ & Te-129m & $7.8 \times 10^{-1}$ & TOTAL & $1.6 \times 10^{6}$ \\
\hline$N b-95$ & $7.2 \times 10^{3}$ & Te-129 & $5.0 \times 10^{-1}$ & & \\
\hline Tc-99 & $1.6 \times 10^{1}$ & I-129 & $4.6 \times 10^{-2}$ & & \\
\hline Ru- 103 & $8.4 \times 10^{7}$ & & & & \\
\hline $\mathrm{Rh}-103 \mathrm{~m}$ & $8.4 \times 10^{1}$ & & & & \\
\hline $\mathrm{Ru}-106$ & $3.1 \times 10^{5}$ & & & & \\
\hline Rh-106 & $3.1 \times 10^{5}$ & Cs-134 & $1.1 \times 10^{5}$ & & \\
\hline$P d-107$ & $2.3 \times 10^{-1}$ & Cs-135 & $4.2 \times 10^{-1}$ & & \\
\hline $\mathrm{Ag}-110 \mathrm{~m}$ & $1.5 \times 10^{3}$ & Cs-136 & & & \\
\hline $\mathrm{Ag}-110$ & $1.9 \times 10^{2}$ & Cs -137 & $1.1 \times 10^{5}$ & & \\
\hline & & $\mathrm{Ba}-137 \mathrm{~m}$ & $9.8 \times 10^{4}$ & & \\
\hline $\mathrm{Cd}-113 \mathrm{~m}$ & $1.6 \times 10^{1}$ & & & & \\
\hline In- $114 m$ & $1.1 \times 10^{-3}$ & & & & \\
\hline In- 114 & $1.0 \times 10^{-3}$ & Ce-141 & 9.1 & & \\
\hline Cd-115m & $8.9 \times 10^{-2}$ & & & & \\
\hline & & $\mathrm{Ce}-144$ & $2.4 \times 10^{5}$ & & \\
\hline$S n-119 m$ & 4.7 & $\operatorname{Pr}-144$ & $2.4 \times 10^{5}$ & & \\
\hline
\end{tabular}

(a) Values less than $1.0 \times 10^{-5}$ curies/MTHM have been ignored. Radioactivities for decay time of 18 months out-of-reactor. 
TABLE C.4. Hulls and Hardware Radionuclides In Spent, Coprocessed Fuel(a)

\begin{tabular}{|c|c|c|c|}
\hline \multicolumn{2}{|c|}{ Hardware } & \multicolumn{2}{|c|}{ Hulls } \\
\hline Radioisotope & $\begin{array}{l}\text { Activity } \\
\text { (Ci/MTHM) }\end{array}$ & Radioisotope & $\begin{array}{l}\text { Activity } \\
\text { (Ci/MTHM) }\end{array}$ \\
\hline${ }^{14} \mathrm{C}$ & $5.0 \times 10^{-2}$ & ${ }^{14} \mathrm{C}$ & $6.0 \times 10^{-2}$ \\
\hline $35_{\mathrm{s}}$ & $4.0 \times 10^{-3}$ & ${ }^{35} s$ & $9.0 \times 10^{-3}$ \\
\hline${ }^{45} \mathrm{Ca}$ & $3.0 \times 10^{-3}$ & $54 \mathrm{Mn}$ & 2.0 \\
\hline${ }^{46} \mathrm{Sc}$ & $4.0 \times 10^{-2}$ & ${ }^{55} \mathrm{Fe}$ & $9.0 \times 10^{1}$ \\
\hline $54 \mathrm{Mn}$ & $2.0 \times 10^{2}$ & ${ }^{58} \mathrm{Co}_{0}$ & 2.0 \\
\hline${ }^{55} \mathrm{Fe}$ & $4.0 \times 10^{3}$ & ${ }^{60} \mathrm{Co}_{0}$ & $1.0 \times 10^{2}$ \\
\hline${ }^{58} \mathrm{Co}_{0}$ & 2.0 & ${ }^{59} \mathrm{Ni}$ & $3.0 \times 10^{-2}$ \\
\hline${ }^{60} \mathrm{Co}$ & $4.0 \times 10^{3}$ & $63_{\mathrm{Ni}}$ & 4.0 \\
\hline${ }^{59} \mathrm{Ni}$ & 3.0 & ${ }^{93} \mathrm{Zr}$ & $9.0 \times 10^{-2}$ \\
\hline $63_{\mathrm{Ni}}$ & $4.0 \times 10^{2}$ & ${ }^{95} \mathrm{Zr}$ & $8.0 \times 10$ \\
\hline $65_{Z n}$ & 6.0 & ${ }^{95} \mathrm{Nb}$ & $2.0 \times 10^{2}$ \\
\hline $90 \mathrm{Sr}$ & $1.0 \times 10^{-3}$ & $113_{C d}$ & $5.0 \times 10^{-3}$ \\
\hline $90 y$ & $1.0 \times 10^{-3}$ & $119_{m_{S n}}$ & 5.0 \\
\hline $93 m_{N b}$ & $9.0 \times 10^{-3}$ & $121 \underline{m}_{S n}$ & $3.0 \times 10^{-1}$ \\
\hline${ }^{94} \mathrm{Nb}$ & $1.0 \times 10^{-4}$ & ${ }^{123} \mathrm{Sn}$ & $2.0 \times 10^{-2}$ \\
\hline $93 \mathrm{Mo}$ & $7.0 \times 10^{-3}$ & $181_{W}$ & $2.0 \times 10^{-4}$ \\
\hline${ }^{99} \mathrm{Tc}$ & $7.0 \times 10^{-3}$ & & \\
\hline $113_{-\mathrm{m}}$ & 4.0 & Total & $4.8 \times 10^{2}$ \\
\hline $125_{\mathrm{Sb}}$ & $2.0 \times 10^{1}$ & & \\
\hline $125 m_{\mathrm{Te}}$ & $1.0 \times 10^{1}$ & & \\
\hline $181_{W}$ & $7.0 \times 10^{-5}$ & & \\
\hline Total & $8.7 \times 10^{3}$ & & \\
\hline
\end{tabular}

(a) Radioactivities for decay time of 18-months out-of-reactor. 


\section{C.1.3 Facility Inventories}

Each nuclear fuel cycle facility has an inventory of radionuclides, either fuel or wastes. Table C.5 lists assumptions on fuel cycle facility capacity, throughput and inventories. Table C.6 lists the inventory of radionuclides in radioactive wastes in the spent fuel storage basin of the separations facility.

\section{C.2 PROCESSES AND WASTES}

In this section, the conventional PUREX process is first described to provide a basis for the discussion of the coprocessing facility which follows. Within the discussion, major differences between the facility and the conventional PUREX process are highlighted.

\section{C.2.1 PUREX Process}

The PUREX process will be described as embodied by the Barnwell Nuclear Fuels Plant. ${ }^{(7)}$ Description of the reference coprocessing facility relative to that basis will facilitate comparison of projected reprocessing wastes in References 8 and 9 for a Barnwell type facility. An overall flow diagram for the Barnwell plant is given in Figure 2.1. (7)

\section{C.2.1.1 Cask Handling}

The irradiated fuel assemblies arrive at the plant in shielded casks. The cask and transport vehicle are monitored for outside contamination and washed to remove outside dirt. The cask is removed from the carrier and the condition of the fuel and cask coolant is determined. The cask is vented and the primary coolant is replaced if necessary.

The cooled cask is transported by the cask handling crane to the cask unloading pool (CUP) where it is submerged in the water and lowered to the bottom of the pool. The top of the cask is opened and the contained fuel is removed (all under water). The fuel is placed in storage canisters that are moved to the fuel storage pool (FSP) for retention until the fuel is scheduled for reprocessing. 
TABLE C.5. Fuel Cycle Facility Sizes and Inventories

Pressurized Water Reactor

Size

Capacity Factor

Fuel Inventory

In-Core

In Basin

Waste Inventory

Fuel Coprocessing Plant

Size

Annual Operating Time

Fuel Inventory

In Basin

In Plant (Process)

Waste Inventory

MOX Fabrication Plant

Size

Annual Operating Time

Fuel Inventory

Waste Inventory
-- 1200 MWe

-. $\quad 0.7$

-- 100 MTHM

-- 27 MTHM

-- 1/4 Annual Output

-- $2000 \mathrm{MTHM} / \mathrm{yr}$

-- 300 days

-- 500 MTHM

-- 200 MTHM

-- 1/4 Annual Output

-- 400 MTHM/yr

-- 300 days

-- 40 MTHM

-- 1/4 Annual Output 
TABLE C.6. Radionuclides in Wastes Generated in Receiving Spent Fuel at the Coprocessing Plant

ACTIVATION PRODUCTS

$\mathrm{Cr}-51$
$\mathrm{Mn}-54$
$\mathrm{Fe}-55$
$\mathrm{Fe}-59$
$\mathrm{Co}-58$
Co-60
Subtotal

$2.3 \times 10^{-4}$

$1.1 \times 10^{-2}$

$2.3 \times 10^{-1}$

$1.8 \times 10^{-3}$

$6.5 \times 10^{-2}$

$1.5 \times 10^{-1}$

$4.6 \times 10^{-1}$

FISSION PRODUCTS

Sr-89
Sr-90
$\mathrm{Zr}-95$
$\mathrm{Ru}-103$
$\mathrm{Ru}-106$
$\mathrm{Te}-127 \mathrm{~m}$
$\mathrm{Te}-129 \mathrm{~m}$
$\mathrm{Cs}-134$
$\mathrm{Cs}-137$
$\mathrm{Ce}-141$
$\mathrm{Ce}-144$
Subtotal

$9.5 \times 10^{-3}$

$1.9 \times 10^{-2}$

$4.3 \times 10^{-4}$

$3.6 \times 10^{-5}$

$1.1 \times 10^{-3}$

$4.3 \times 10^{-3}$

$4.6 \times 10^{-2}$

1.1

1.1

$4.4 \times 10^{-5}$

$2.6 \times 10^{-3}$

2.2

Total

2.7 


\section{C.2.1.2 Fuel Shearing and Dissolution}

The fuel shearing and dissolution processes are generally called "head-end" operations. The fuel assemblies are remotely transferred form the storage pool to the feed mechanism of the mechanical shear after a full batch has been accumulated. Here the fuel assemblies are chopped into small segments (5 to $12 \mathrm{~cm}$ long) to expose the fuel to the dissolvent. The fuel segments fall into the dissolver containing hot 3 to 8 molar (M) nitric acid which dissolves virtually all the uranium, plutonium, and nongaseous fission products. Gadolinium nitrate is added to the dissolver solution to supplement the "safe" geometry of the tanks preventing nuclear criticality excursions. The undissolved cladding hulls remain in the dissolver basket. The cladding hulls are rinsed, monitored for fissile material, packaged, and transferred to the interim underground waste storage area for eventual shipment offsite. Gases generated during dissolution are channeled to the off-gas treatment system to remove particulates, radioiodine, and nitrogen oxides.

The dissolver solution is transferred to tanks for uranium and plutonium accountability sampling and final acid adjustment to 2 to $3 \mathrm{M}$ nitric acid before feeding to the solvent extraction process. The solution is centrifuged to remove fine solids which are sent to the high-level waste storage system.

\section{C.2.1.3 Solvent Extraction Cycles}

The acid-adjusted and centrifuged solution is sent to the first solvent extraction cycle where it is contacted counter-currently in a 10-stage centrifugal contactor with an organic solution of $30 \%$ tributyl phosphate (TBP) in normal paraffin hydrocarbon diluent (dodecane). The organic solution preferentially extracts the tetravalent plutonium and hexavalent uranium, leaving about $95 \%$ of the fission products in the aqueous solution. The organic solution from the centrifugal contactor passes through a pulsed scrub column where a $3 \mathrm{M}$ aqueous nitric acid solution removes about $96 \%$ of the extracted fission products and is recycled back to the centrifugal contactor. The aqueous solution leaving the centrifugal contactor contains about $99.9 \%$ of the fission products and about $0.5 \%$ of the uranium and plutonium, and is sent to a high-level waste concentrator. The organic solution from the pulsed 
scrub column passes through a partitioning column where tetravalent plutonium is electrochemically reduced to the less extractable trivalent state. This enables the plutonium to be stripped into an aqueous nitric acid solution containing hydrazine as a holding chemical reductant, a11 within the same electrochemical device. The organic solution passes through the final first cycle column where the uranium is stripped into acidified water (about 0.01 Mnitric acid).

The aqueous strip solution is concentrated from $0.3 \underline{\mathrm{M}}$ uranium to $1.5 \mathrm{M}$ uranium, adjusted with nitric acid, and sent to the second uranium solvent extraction cycle where it is again preferentially extracted by another $30 \%$ TBP organic solution in a pulsed column. Before leaving this column, the organic solution containing the uranium is scrubbed with 2.3 M nitric acid solution which removes the extracted fission products (mostly zirconium-niobium and ruthenium). Hydroxylamine nitrate and hydrazine are also added to the scrub solution to chemically reduce the residual plutonium to remove the less extractable trivalent plutonium into the aqueous stream. Uranium is stripped from the organic solution in another pulsed column, using acidified water (0.01 M nitric acid). This solution is concentrated from $0.4 \mathrm{M}$ uranium to $1.5 \mathrm{M}$ uranium by boiling off some of the water. Finally, the concentrated uranium solution from the second cycle is passed through silica gel beds to remove residual zirconium-niobium. Uranyl nitrate product solution is analyzed and transferred to the $U_{F}$ conversion facility.

Plutonium in the aqueous stream leaving the partitioning column in the first cycle is reoxidized to the extractable tretravalent state with a nitrate chemical and sent to the second plutonium solvent extraction cycle. Here, it is preferentially extracted into the TBP organic solution in another pulsed extraction column. In the top portion of the same column, the organic stream is scrubbed with $1.0 \mathrm{M}$ nitric acid solution to remove extracted ruthenium and zirconium-niobium. The organic stream passes through a strip column where tetravalent plutonium is transferred to an aqueous stream of dilute $(0.3 \underline{M})$ nitric acid. 
The extraction-scrubbing sequence is repeated in a third plutonium cycle for further decontamination from fission products. To effect a higher plutonium product concentration, the plutonium is reduced in the third strip column by hydroxylamine nitrate to the more readily strippable trivalent state. A TBP organic scrub solution is added to remove residual uranium from the plutonium aqueous stream as it leaves the third strip column. The plutonium nitrate solution is washed with an organic stream of diluent to remove traces of TBP. Final concentration of the plutonium product stream from $60 \mathrm{~g} \mathrm{Pu} / 1$ iter to $250 \mathrm{~g} \mathrm{Pu} / \mathrm{liter}$ is accomplished by boiling off water and nitric acid in a titanium concentrator. The plutonium product solution is analyzed and stored in tanks with a nuclear criticality-safe geometry before transfer to the plutonium dioxide conversion facility.

\section{C.2.1.4 Secondary Product Recovery}

The aqueous raffinate (waste) streams from the plutonium and uranium cycles are treated with nitrite salt or $\mathrm{NO}_{2}$ gas to adjust the plutonium and uranium valence to +4 and passed through a secondary recovery solvent extraction cycle. Here, they are processed in a pulse column where residual uranium and plutonium are recovered by extraction into a TBP-organic solution. The uranium and plutonium are recycled back to the first (codecontamination) cycle for decontamination and recovery. The aqueous raffinate stream is concentrated in a low-level process waste concentrator.

\section{C.2.1.5 Organic Solvent Treatment}

The organic solvent waste streams from the first and partition cycles are washed with successive dilute aqueous solutions of sodium carbonate, nitric acid, and sodium carbonate to remove organic degradation products by extraction or precipitation. Precipitated solids are removed by filtration. Fresh TBP or diluent is added as required to maintain the $30 \%$ TBP concentration and the total solvent inventory. 
The organic solvent waste stream from the second uranium cycle is treated similarly, except the second alkaline wash is omitted. This solvent extractant is kept in a separate system. Degraded solvent is burned.

\section{C.2.1.6 Waste Concentration and Acid Recycle}

The radioactive aqueous waste streams from all the solvent extraction cycles are concentrated in the high-level and/or low-level waste concentrators. The acidic concentrated bottoms from high-level waste concentration are stored for an interim period in cooled stainless steel waste tanks, and the overheads are passed through a low-level waste concentrator and then to a distillation (fractionation) column to recover most of the nitric acid as a $12 \mathrm{M}$ solution. The overheads (primarily water) are then recycled as process water, or sampled and released to the stack from a vaporizer. The $12 \mathrm{M}$ recovered acid is used in the process where the residual radioactivity can be tolerated.

Miscellaneous liquid process waste streams containing salts and radioactivity are acidified and concentrated in a general purpose concentrator. The concentrator bottoms are stored in an uncooled stainless steel waste tank as intermediate-level liquid waste and the condensed overheads are vaporized to the stack.

\section{C.2.1.7 Off-Gas Treatment}

Off gases from the dissolver are scrubbed with circulating mercuric nitrate-nitric acid solution to remove radioactive iodine, then treated in an absorber to convert nitrogen oxides to nitric acid suitable for recycling. The dissolver and vessel off-gas streams are combined and passed through a second iodine scrubber containing mercuric nitrate, then through iodine adsorber beds, and finally through high-efficiency filters before release to the main stack.

\section{C.2.1.8 Further Processing}

The above description does not include the processing steps to convert uranium nitrate product to $\mathrm{UF}_{6}$, convert plutonium nitrate product to mixed oxide fuel and to solidify the liquid waste streams. Those steps will be included in the coprocessing description which follows. Bartlett et al. describe those steps as applied to convential reprocessing. 


\section{C.2.2 The Coprocessing Facility}

The coprocessing goal of producing a U/Pu product which is not completely decontaminated from fission products is accomplished in the reference process by simplification and minor modification of the solvent extraction portion of the PUREX process. The only major equipment change is the elimination of the second and third plutonium purification cycles which precludes complete decontamination and separation from $U$ of the Pu product. In addition, some modification is also likely in the design of the first (HA) solvent extraction column for a smaller scrub capacity, and of the partitioning (IB) column for a lower organic to aqueous flow ratio. Such modification allows specific requirements for decontamination factor and $\mathrm{U} / \mathrm{Pu}$ ratio to be met.

\section{C.2.2.1 Flowsheet Assumptions}

Figures C.2 through C.5 show an overall flow diagram for the reference coprocessing facility. Table $\mathrm{C} .7$ lists the distribution of radionuclides between the input streams to waste management. Waste management refers to that portion of the flowsheet which appears on Figure C.4 and C.5. The following assumptions were made about the behavior of the radionuclides based on review of the literature and specific references as noted:

U/Pu: Behavior is estimated by analogy with flowsheets in references 7 and 10. Loss of Pu to the U stream in IB is based on a Barnwell specification found to be achievable under coprocessing conditions by SRL researchers (reference 6 ).

I: $90 \%$ is volatilized in dissolver according to GESMO (reference 12) pg. IVE-28). Most of remainder reacts irreversibly with solvent. $99 \%$ volatility is assumed in evaporators. Behavior in off-gas condensers is based on vapor-liquid equilibrium of $\mathrm{I}_{2}$ in $\mathrm{H}_{2} \mathrm{O}$ at $40^{\circ} \mathrm{C}$.

$\mathrm{Ru} / \mathrm{Zr} / \mathrm{Nb}$ : Based on the flowsheet and equilibrium data in reference 7 , a DF decontamination factor of 20 is assumed in the HA and 20 columns. $\mathrm{Ru}$ is treated separately only where volatility is likely.

$\mathrm{Xe} / \mathrm{Kr}$ : Inert gases follow off-gas stream exclusively from dissolver to stack.

${ }^{14} \mathrm{C}$ : Carbon is assumed to be completely oxidized to $\mathrm{CO}_{2}$ and thereafter to behave as an inert gas. 


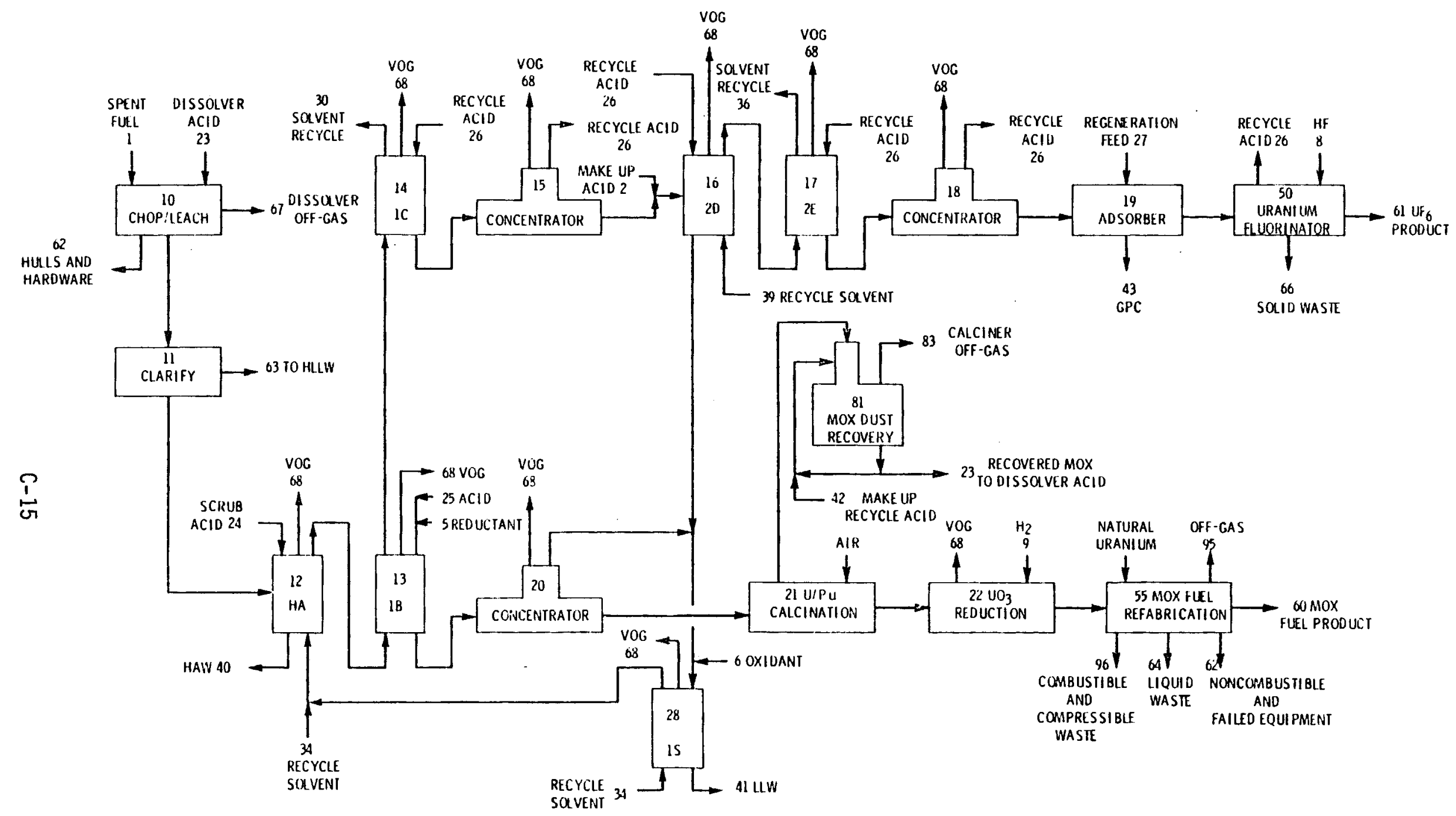

FIGURE C.2. Overall Flow Diagram for Conceptualized Coprocessing Facility 


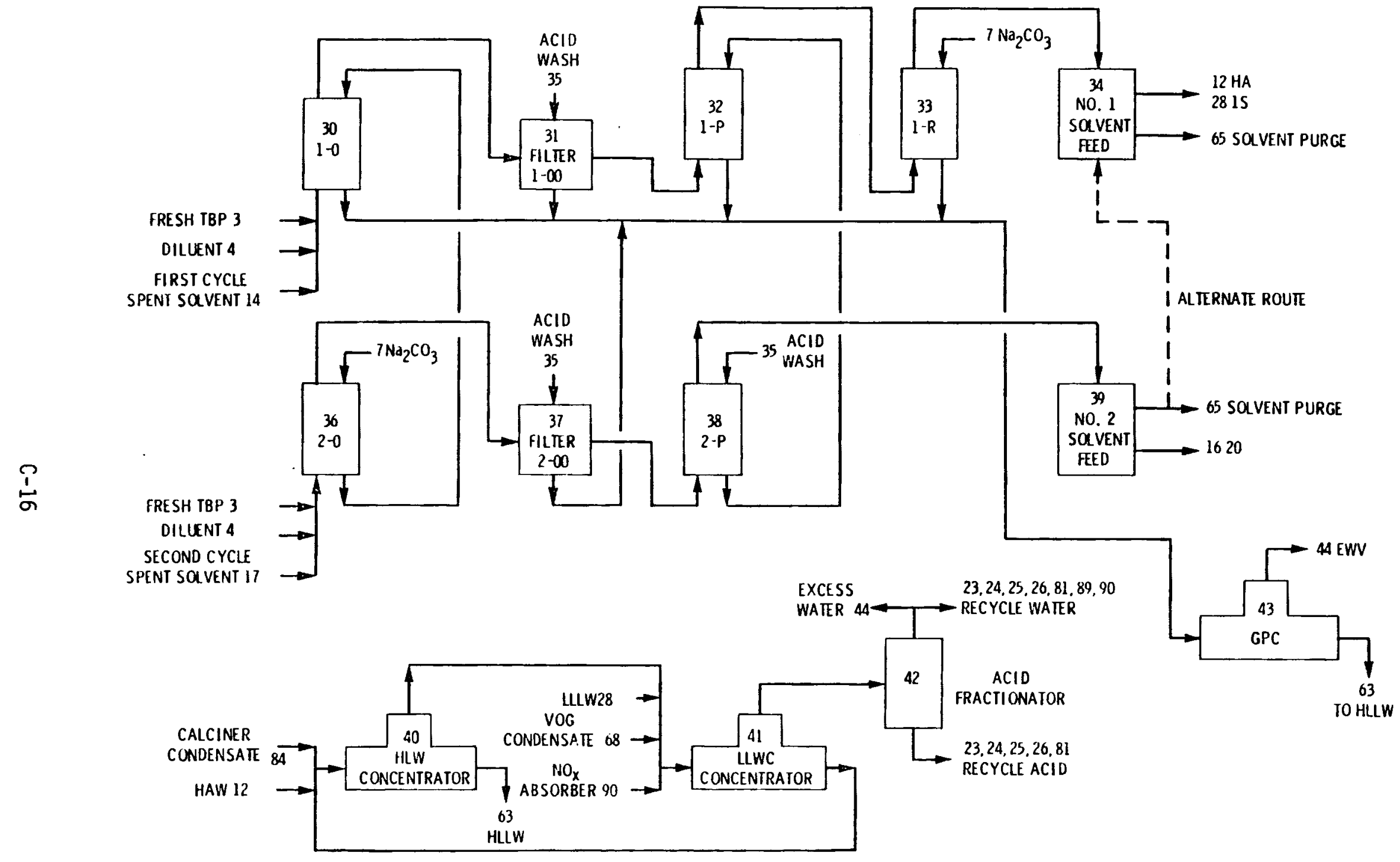

FIGURE C.3. Spent Solvent Cleanup and HLW/LLW Concentration Flow Diagram for Conceptualized Coprocessing Facility 


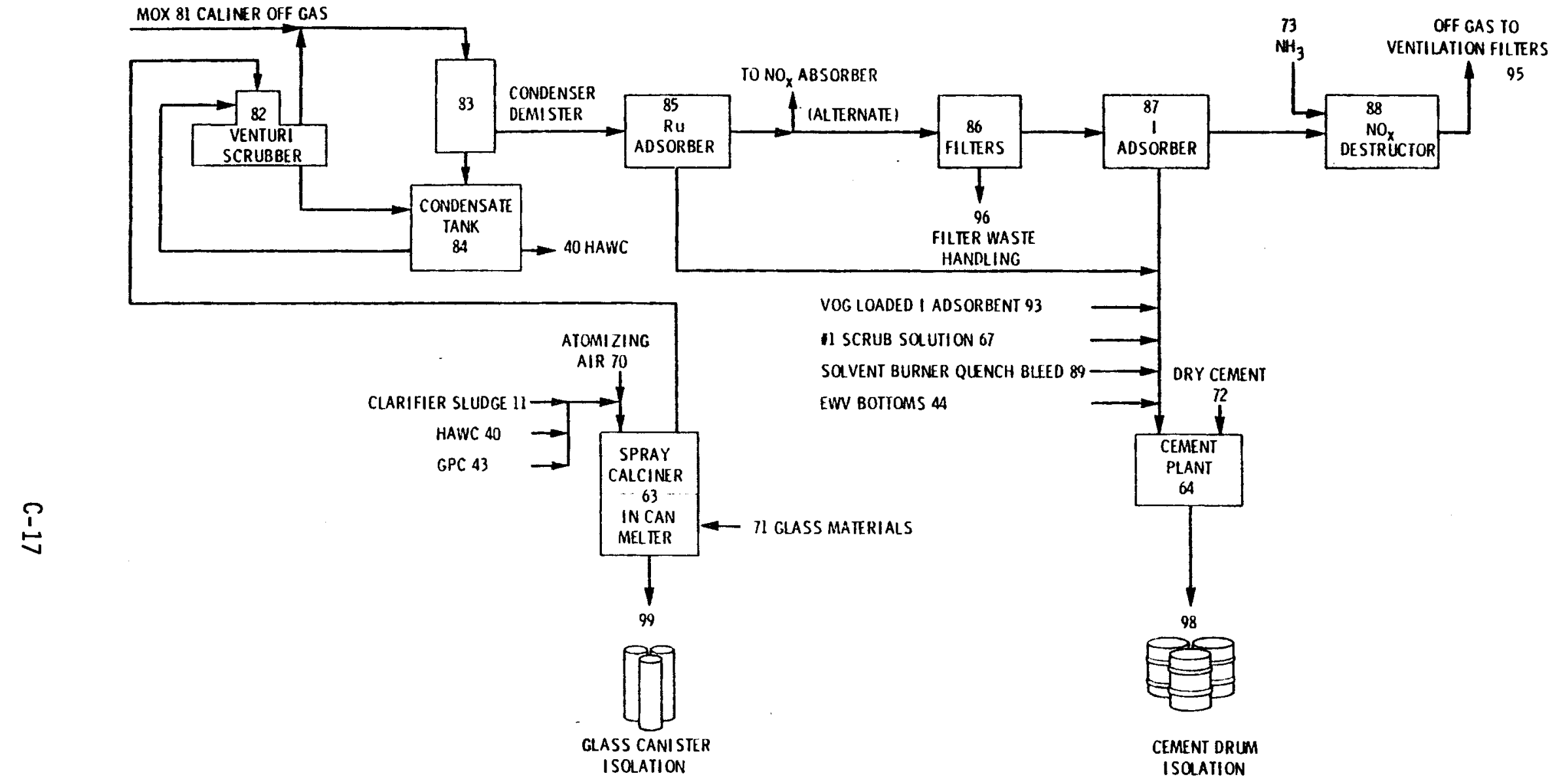

FIGURE C.4. HLW and LLW Immobilization Flow Diagram for Conceptualized Coprocessing Facility 


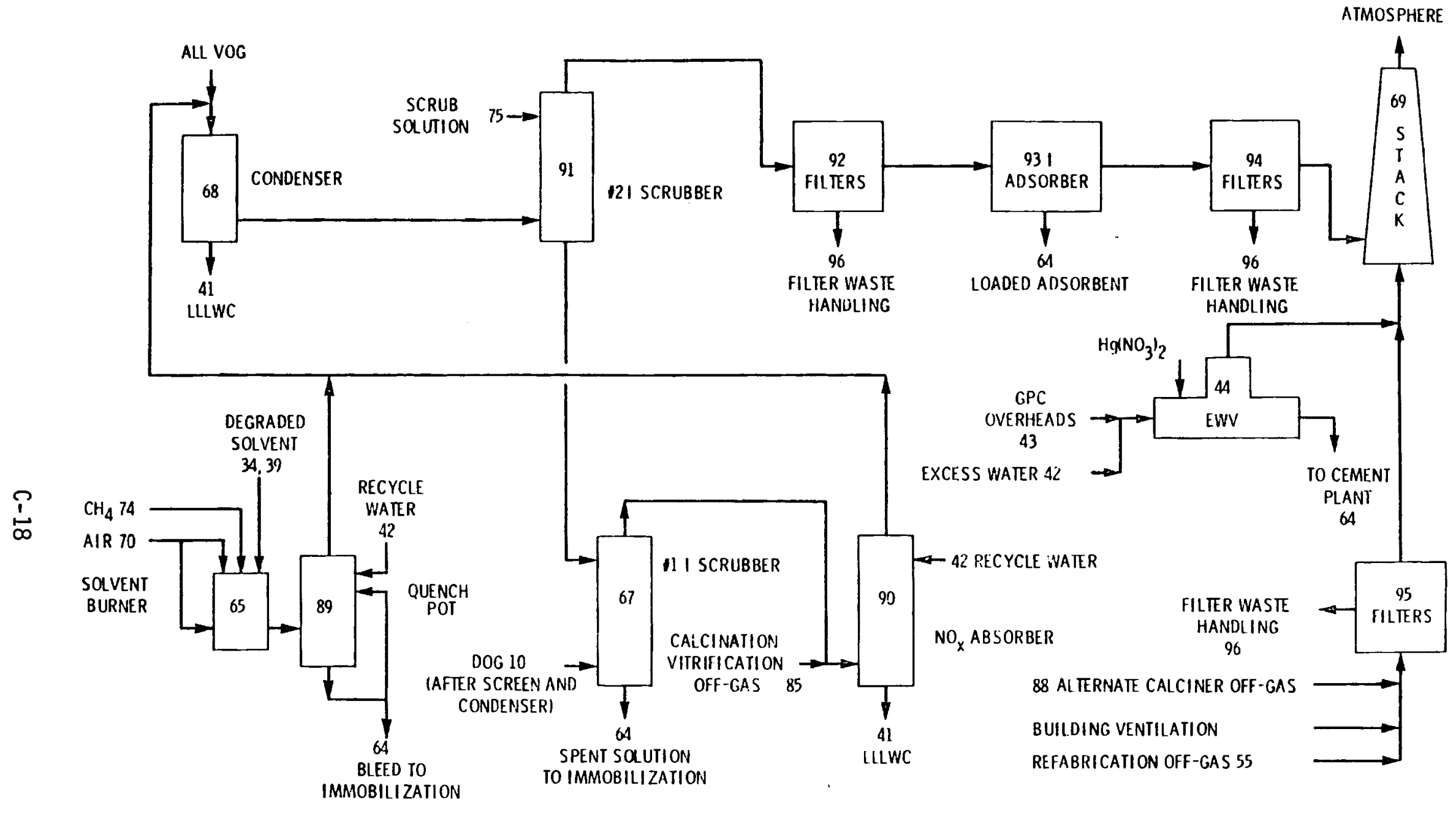

FIGURE C.5. Off-Gas System Flow Diagram for Conceptualized Coprocessing Facility 


\section{LEGEND}

FIGURES C.2 THRUUGH C.5

FEED, UNIT AND PROJECT NUMBERS

1. Spent Fue1

2. Nitric Acid

3. TBP

4. Diluent

5. Reductant

6. Oxidant

7. $\mathrm{Na}_{2} \mathrm{CO}_{3}$

8. $\mathrm{HF}^{2}$

9. $\mathrm{H}_{2}$

10. Chop/Leach

11. Clarify

12. HA Col.

13. 1B Col.

14. IC Col.

15. Concentrator

16. 2D Col.

17. 2E Col.

18. Concentrator, $U$

19. Si Gel Bej

20. Concentrator, $\mathrm{U} / \mathrm{Pu}$

21. Pu/u Calciner

22. $\mathrm{H}_{2}$ Reduction Furnace

23. Díssolver Acid, $7.7 \mathrm{M}$

24. HA Scrub Acid, 3M

25. IB Extractant Acid, 2M

26. $2^{\text {nd }}$ Cycle Acid, $0.01 \mathrm{M}$

27. Si Gel Regenerant

28. IS Col.

30. 1-0 Col.

31. 1-00 Filters

32. I-P Col.

33. 1-R Col.

34. \#1 Solvent Feed

35. Wash Acid, .2M

36. 2-0 Col.

37. 2-00 Filters

38. 2-P Col.

39. \#2 Solvent Feed

40. HAW Concentrator

41. LAW Concentrator
42. Acid Fractionator

43. General Purpose Concentrator

44. Excess Water Vaporizer

45. Misc. Plant Liquids

50. Fluorinator

55. MOX Refab plant

60. MOX Fuel

61. $U F_{6}$ Product

62. Huils \& Hardware, MOX Solids

63. HLLW (SC/ICM)

64. Cement Plant

65. Degraded Solvent Burner

66. Fluorinator Residue: a) dry; b) mud

67. DOG (\#1 I scrub)

68. VOG (Condenser)

69. Stack

70. Controlled Pressure Air

71. Glass Materials

72. Dry Cement

73. $\mathrm{NH}_{3}$

74. $\mathrm{CH}_{4}$

75. $\mathrm{Hg}_{2}\left(\mathrm{NO}_{3}\right)_{2}$ in $\mathrm{HNO}_{3}$

81. MoX Dust Venturi

82. Venturi scrubber

83. Condenser/Demister

84. Condensate Tank

85. Ru Adsorber

86. Alternate filters

87. Alternate I Adsorber

88. Alternate N0x Destructor

89. Solvent Burner Quench Pot

90. NOx Absorber

91. \#2 I scrub

92. Roughing \& HEPA, VOG

93. I Absorber, VOG

94. Roughing \& HEPA, VOG - Final

95. Roughing \& HEPA, Ventilation

96. Filter Waste Handling; Compactable and Combustable Waste

98. Cement Drum Isolation

99. Glass Canister Isolation 
TABLE C.7. Primary Wastes from Coprocessing Radionuclide Content, Fraction of Spent Fuel Inventory

\begin{tabular}{|c|c|c|c|c|c|c|c|c|c|c|c|}
\hline Was te & Flowsheet \# & $\mathrm{Pu}$ & $\underline{N P}$ & $\underline{U}$ & $\mathrm{I}$ & $\underline{\mathrm{Ru} / \mathrm{Ru}}$ & $\underline{\mathrm{Zr} / \mathrm{Nb}}$ & $3_{H}$ & Other Nuclides $(\mathrm{a})$ & $\begin{array}{l}\text { Volume } \\
\text { (b) } \\
\text { (liter/MTHM) }\end{array}$ & $\begin{array}{c}\mathrm{HNO}_{3} \\
\text { (moles/liter) } \\
\end{array}$ \\
\hline $\begin{array}{l}\text { Dissolver } \\
\text { Off Gas (OG) }\end{array}$ & $10-67$ & $5 E-4$ & $5 E-4$ & $5 E-4$ & 0.9 & $5 E-4$ & $5 E-4$ & 0.05 & $5 E-4$ & $77^{(b)}$ & -- \\
\hline $\begin{array}{l}\text { Hul1s \& } \\
\text { Hardware }\end{array}$ & $10-62$ & $5 E-4$ & $5 E-4$ & $5 E-4$ & -- & $5 E-4$ & $5 E-4$ & 0.15 & $5 E-4$ & 330 & -- \\
\hline $\begin{array}{l}\text { Degraded } \\
\text { Solvent }\end{array}$ & $\begin{array}{l}34-65 \\
34-69\end{array}$ & $1 E-12$ & $3 E-10$ & $2.4 E-8$ & 0.10 & $5 E-11$ & $5 E-11$ & -- & $5 E-13$ & 50 & -- \\
\hline $\begin{array}{l}\text { Excess } \\
\text { Water }\end{array}$ & $\begin{array}{l}42-44 \\
43-44\end{array}$ & $1.2 \mathrm{E}-9$ & $4 E-9$ & $9 E-8$ & $3 E-4$ & $3.5 E-8$ & $3.5 \mathrm{E}-8$ & 0.835 & $2.5 E-9$ & 3040 & 0.01 \\
\hline $\begin{array}{l}\text { High-Level } \\
\text { Liquid Waste }\end{array}$ & $\begin{array}{l}11-63 \\
40-63 \\
43-63\end{array}$ & $5.2 \mathrm{E}-3$ & 0.97 & $2.1 \mathrm{E}-3$ & $3 E-7$ & 0.95 & 0.95 & $6.8 \mathrm{E}-2$ & 0.99 & 710 & 8.5 \\
\hline $\begin{array}{l}\text { Mixed Nitrate } \\
\text { Calciner } 0 G\end{array}$ & $81-83$ & $5 E-5$ & $1.8 \mathrm{E}-6$ & $7 E-6$ & $1 E-7$ & $4.5 E-3$ & $2.4 \mathrm{E}-6$ & -- & $2.5 \mathrm{E}-7$ & $62^{(b)}$ & -- \\
\hline $\begin{array}{l}\text { Process } \\
\text { Vessel OG }\end{array}$ & $\begin{array}{l}\text { All } \\
\text { Vog }\end{array}$ & $1 E-3$ & $4.6 \mathrm{E}-5$ & $1.9 E-4$ & $3 E-6$ & $5.6 \mathrm{E}-5$ & $5.6 \mathrm{E}-5$ & $8 E-6$ & $1.5 \mathrm{E}-5$ & $592^{(b)}$ & -- \\
\hline $\begin{array}{l}\text { Waste } \\
\text { Recycle }\end{array}$ & $\begin{array}{l}68-41 \\
90-41 \\
84-40\end{array}$ & $1.1 \mathrm{E}-4$ & $1.0 E-3$ & $8.2 E-5$ & $1.9 \mathrm{E}-3$ & $5.7 \mathrm{E}-4$ & $1 E-3$ & 0.103 & $1.1 \mathrm{E}-3$ & 4900 & 3.0 \\
\hline $\begin{array}{l}\text { Fluorinator: } \\
\text { Dry } \\
\text { Mud }\end{array}$ & $\begin{array}{l}50-66 \mathrm{a} \\
50-66 \mathrm{~b}\end{array}$ & $\begin{array}{l}1.2 \mathrm{E}-6 \\
--\end{array}$ & $\begin{array}{l}-- \\
--\end{array}$ & $\begin{array}{l}1.5 \mathrm{E}-3 \\
-.\end{array}$ & $\begin{array}{l}-- \\
\cdots\end{array}$ & $1 E-6$ & $2 E-7$ & $\begin{array}{l}-- \\
--\end{array}$ & $\begin{array}{l}-- \\
--\end{array}$ & $\begin{array}{r}530 \\
70\end{array}$ & $=$ \\
\hline $\begin{array}{l}\text { Mox Refab: } \\
\text { Gas } \\
\text { Wet }\end{array}$ & $\begin{array}{l}60-95 \\
60-64\end{array}$ & $\begin{array}{l}3 E-7 \\
1 E-4\end{array}$ & $\begin{array}{l}1 \mathrm{E}-8 \\
3.5 \mathrm{E}-6\end{array}$ & $\begin{array}{l}4 E-8 \\
1.4 E-5\end{array}$ & $\begin{array}{l}-- \\
--\end{array}$ & $\begin{array}{l}1.4 E-8 \\
5 E-6\end{array}$ & $\begin{array}{l}1.4 E-8 \\
5 E-6\end{array}$ & $\begin{array}{l}-- \\
--\end{array}$ & $\begin{array}{l}1.5 E-9 \\
5 E-7\end{array}$ & $\begin{array}{l}9000^{(b)} \\
80\end{array}$ & $\begin{array}{l}-- \\
--\end{array}$ \\
\hline Combustible & $60-96$ & $1 E-3$ & $3.5 E-5$ & $1.4 \mathrm{E}-4$ & -- & $5 E-5$ & $5 E-5$ & -- & $5 E-5$ & 120 & -- \\
\hline Noncombus tible & $60-62$ & $1 E-4$ & $3.5 E-6$ & $1.4 E-5$ & -- & $5 E-6$ & $5 E-6$ & -- & $5 E-7$ & 80 & -- \\
\hline
\end{tabular}

(a) Includes other lower case actinides and fission products except $\mathrm{Kr}$, Xe and $\mathrm{C}$ which pass completely and uniquely into the dissolver off gas. (b) Gas volumes in $\mathrm{Kg}$-moles/MTHM, composition in Table C.2.

(c) Streams containing nitric acid to be recycled. 
${ }^{3} \mathrm{H}$ : Bahavior at head end is based on reference 8 , figure $2.25, \mathrm{pg} .2 .64$. Thereafter it follows $\mathrm{H}_{2} \mathrm{O}$.

Other Actinides and Fission Products: Assumed to be 1/10 as extractable as $\mathrm{Ru} / \mathrm{Zr} / \mathrm{Nb}$.

\section{C.2.2.2 Head End and Solvent Extraction}

The reference process is essentially identical to the PUREX process from cask handling through the dissolution operations. The flowsheets begin to differ at the HA column.

The aqueous stream leaving the $H A$ column removes only $98.6 \%$ of the fission products to the high-level waste concentrator. Carried over in the organic extract are $5 \%$ of the $\mathrm{Zr} / \mathrm{Nb} / \mathrm{Ru}$ and $0.5 \%$ of the other fission products and actinides. For material balance purposes it is assumed that a $50 \%$ reduction in scrub flow accomplishes the reduction in decontamination.

In the IB column $13.6 \%$ of the uranium is stripped into the aqueous stream along with the Pu. Savannah River Laboratory has demonstrated (reference 11) this step using hydroxyl amine nitrate (HAN) as a Pu reductant and found that the amount of $U$ stripped can be controlled by nitrate salt content where, beyond a minimum amount required for reduction, the salt can be either HAN or ammonium nitrate. HAN will probably be used alone since it decomposes easily to $\mathrm{NO}_{\mathrm{x}}$ in later processing steps. For material balance purposes, it is assumed that the desired degree of $U$ separation is achieved by a $176 \%$ increase in aqueous to organic flow ratio over that used in the Barnwell plant where only $5.2 \%$ of the $U$ is stripped.

The uranium purification cycle is identical to the PUREX process as described above. Decontamination in the 20 column was conservatively estimated to be the same as in the HA column. Although more extractable (less easily separated from $U$ ) chemical forms of the fission products may remain after the first cycle, a full scrub flow and high uranium saturation are used which may result in better decontamination. The raffinate stream contains $3 \%$ of the entering uranium, due to high saturation of the extract. That uranium is recycled via the secondary product recovery column (1S). 
The U/Pu stream leaving the $1 \mathrm{~B}$ column contains most of the fission products which were not extracted in the HA column giving a decontamination factor of 77 . The second and third plutonium purification cycles which would give further decontamination and removal of uranium are eliminated. The aqueous stream is concentrated and goes directly to oxide conversion.

Raffinate from the $1 S$ column and that from the HA column constitute the major liquid wastes from the solvent extraction cycles. Because the second and third plutonium cycles are eliminated, the 15 column handles raffinate, only from the 2D column and condensate from the U/Pu concentrator. 1S raffinate, therefore, has less volume and should contain somewhat less activity than the same stream in the Barnwell flowsheet. Total activity in the two waste streams, however, differs from the Barnwell case only by the relatively small fraction of the fission products which is deliberately left in the U/Pu product stream.

\section{C.2.2.3 Solvent Recycle and Waste Concentration}

The organic solvent clean up and recycle system (Figure C.3) is identical to that used in the Barnwell plant. Iodine that reacts with the solvent will pass through the system and build up through recycle to a level where the sidestream to the burner removes iodine at the same rate it reacts. It was assumed that $0.05 \%$ of all nuclides except I entering the stripping columns ( $1 \mathrm{C}$ and $2 \mathrm{E}$ ) remain in the spent solvent streams. Decontamination by a factor of 100 is assumed in calculating the activity of the sidestream to the burner.

The acid waste concentration and recycle system (Figure C.3) is also similar to the Barnwell plant. Each evaporator is assumed to give a decontamination factor of $10^{4}$ for every nuclide except $I$ and $H$. The nitric acid concentrations were calculated by assuming vapor-liquid equilibrium between the existing streams at $730 \mathrm{~mm} \mathrm{Hg}$ total vapor pressure. Nitric acid concentration in the high level concentrator bottoms is high (9.8 moles/liter). The Barnwell flowsheet uses recycle of overhead and denitration to reduce acidity. For simplicity in material balance those steps are not included in the reference process but could be added if $48 \mathrm{wt} \% \mathrm{HNO}_{3}$ is likely to cause corrosion problems. 
Bottoms from the high-level waste concentrator constitute most of the high-level liquid waste stream (Table C.7) which also includes general purpose concentrator bottoms and sludge from the dissolver acid clarifier. The excess water stream comprises the GPC overheads and a purge from the acid fractionator overheads equal to $10 \%$ of the acid evaporated by the low-level waste concentrator. The purge serves to remove ${ }^{3} \mathrm{H}$ from the process as HTO. The choice of $10 \%$ is arbitrary and requires concentration through recycle by a factor of eight to remove the full load of ${ }^{3} \mathrm{H}$.

Recycle of ${ }^{3} \mathrm{H}$ via the acid recovery column is not included in the material balance upon which Table C.7 is based. Depending on how the recycle acid and water are used in the process, the ${ }^{3} \mathrm{H}$ concentration in the high-level liquid waste stream may be higher than shown in Table 3.1 by a factor up to eight. The extra ${ }^{3} \mathrm{H}$ would return to the process via the waste recycle stream which includes condensate from the waste calciner, mixed nitrate calciner and process vessel off-gas streams. The tritium content in the excess water stream has been adjusted so that the net flow of ${ }^{3} \mathrm{H}$ to waste management is correct.

\section{C.2.2.4 UF $_{6}$ Conversion}

Conversion to UF $_{6}$ is identical for coprocessing and standard reprocessing. A detailed description of a conversion plant has been reported by Savannah River Laboratory (reference 13). Briefly, the uranyl nitrate solution from the uranium purification cycle is dehydrated and heated further to convert urany 1 nitrate to uranium trioxide, which is reduced with hydrogen to form uranium dioxide. Uranium dioxide is converted to uranium tetrafluoride by gaseous hydrogen fluoride, and finally uranium tetrafluoride is converted to the volatile uranium hexafluoride using elemental fluorine.

A description of the wastes from the UF 6 facility can be found in references 8 and 6 . The UF 6 wastes 1 isted in Table $C .7$ were estimated by analogy with that report. Fission products and actinides are assumed to be lost to wastes in the same fraction as that represented by the plutonium content of the wastes described in references 8 and 6 . 


\section{C.2.2.5 Mixed Oxide Conversion}

Conversion of the mixed $\mathrm{U} / \mathrm{Pu}$ nitrate solution to $\mathrm{UO}_{2} / \mathrm{PuO}_{2}$ powder differs from any standard reprocessing step because uranyl nitrate and plutonium nitrate must be treated simultaneously. Currently the most available process to accomplish such a conversion is the "Coprecal" process under development by General Electric Uranium Management Corporation (reference 14). The process reacts the mixed nitrate solution with ammonium hydroxide to form ammonium diuranate, plutonium hydroxide and ammonium nitrate. Subsequent calcination yields $\mathrm{UO}_{3}, \mathrm{PuO}_{2}$ and $\mathrm{NH}_{3}$. It is claimed that the $\mathrm{NH}_{3}$ reacts with the ammonium nitrate to yield $\mathrm{N}_{2}$ and $\mathrm{H}_{2} \mathrm{O}$. The $\mathrm{UO}_{3} / \mathrm{PuO}_{2}$ powder is then reduced with $\mathrm{H}_{2}$ to $\mathrm{UO}_{2} / \mathrm{PuO}_{2}$ and finally adjusted to an empirical formula of $\mathrm{MO}_{2.07}$ by oxidation with $\mathrm{CO}_{2}$.

The explosive potential of ammonium nitrate $\left(\mathrm{NH}_{4} \mathrm{NO}_{3}\right)$ makes the Coprecal process questionable from a safety standpoint. Even if reaction product $\mathrm{NH}_{4} \mathrm{NO}_{3}$ is destroyed by $\mathrm{NH}_{3}$, excess $\mathrm{NH}_{3}$ in the off gas must be removed before mixing with other reprocessing off gases which contain $\mathrm{N}_{\mathrm{x}}$ and could react to form $\mathrm{NH}_{4} \mathrm{NO}_{3}$ in downstream piping.

Oak Ridge National Laboratory is evaluating mixed oxide conversion alternatives for use in the fast breeder reactor cycle. A report prepared by them (reference 15) compared thermal denitration, peroxide precipitation and the Coprecal process. Thermal denitration was indicated as the most attractive route if production of an oxide product favorable for pellet fabrication can be proven. Rockwell Hanford Operations is performing bench scale studies for Oak Ridge on the thermal denitration alternative.

Because significant activity is intentionally left in the U/Pu nitrate stream, mixed oxide conversion in the reference process must be performed remotely, and simplicity is therefore important. The reference process uses thermal denitration (Figure C.2).

Conversion is accomplished by calcination followed by reduction. Although Rockwell Hanford is studying calcination directly to $\mathrm{UO}_{2} \mathrm{PuO}_{2}$ in reducing atmosphere, $\mathrm{UO}_{3}$ reduction is shown here as a separate step. A $10 \% 10$ ss of $\mathrm{Ru}$ to calciner off gas is assumed. If, however, calcination is performed in a 
reducing atmosphere, formation of the volatile oxide of ruthenium should be suppressed. It is assumed ruthenium should be suppressed. It is assumed that nitrates are released as $\mathrm{NO}_{\mathrm{x}}$ and free $\mathrm{HNO}_{3}$ appears in the off gas as $\mathrm{HNO}_{3}$ vapor. A high energy venturi recovers U/Pu containing dust in nitric acid and recycles it to dissolver acid make up. Table C.8 lists nonradioactive components of the gaseous inputs to waste management.

\section{C.2.2.6 Mixed Oxide Fuel Refabrication}

Refabrication of mixed oxide fuel in the reference process involves all of the steps found in standard refabrication with the additional complication that remote operation is required. A description of mixed oxide refabrication can be found in Reference 12, page IV 12-23. The required steps include blending of $\mathrm{PuO}_{2}\left(\mathrm{UO}_{2} / \mathrm{PuO}_{2}\right.$ in the reference case $)$ and $\mathrm{UO}_{2}$ powders, pellet formation, high temperature sintering in a reducing atmosphere ( $6 \%$ hydrogen and $94 \%$ nitrogen), (7) finish grinding cleaning of pellets, tube loading, seal welding and scrap recovery.

Wastes from refabrication 1isted in Table C.7 were estimated from release fractions given in reference 7 . The fractional losses of most fission products and actinides were assumed to be the same as that for plutonium. Cesium is expected to volatize almost completely during the sintering operation. It is estimated to make up $1 \%$ of the "Other Nuclides" present in the mixed oxide powder.

\section{C.2.2.7 Waste Management}

Waste management in the reference facility includes dissolver and process vessel off-gas treatment, degraded solvent burning, vaporization of excess water, high-level liquid waste vitrification and liquid waste fixation in cement. Figures $C .4$ and $C .5$ show the waste management portion of the process. Further handling of process solid wastes and failed equipment is not discussed in this report. Tables C.7 and C.8 describe inputs to the waste management portion of the process. 
TABLE C.8. Nonradiolytic Components, Coprocessing Gaseous Wastes

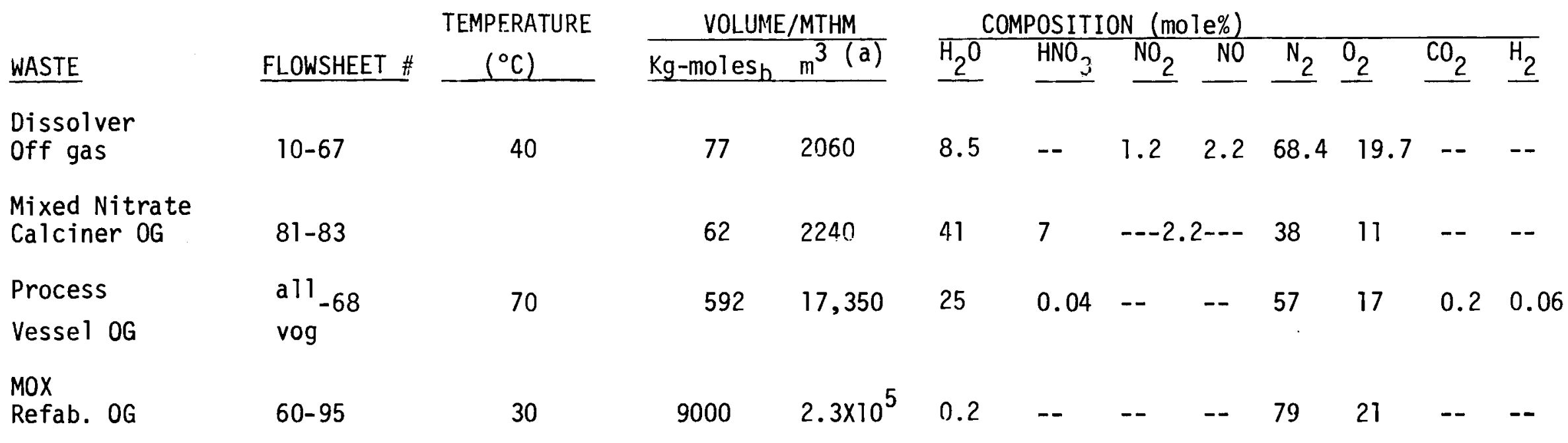

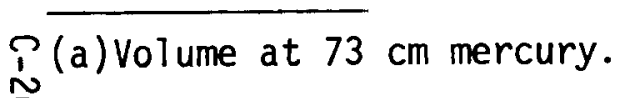

ก 
Gaseous Waste Treatment. Releases of non-volatile radionuclides to the vessel off-gas stream were estimated by assuming generic release fractions as follows:

$\begin{array}{ll}\text { Calciner } & 1 \times 10^{-3} \\ \text { Chopper } & 5 \times 10^{-4} \\ \text { Evaporator } & 1 \times 10^{-4} \\ \text { Column, Dissolver } & 1 \times 10^{-5}\end{array}$

Volume and major components of the stream are nearly identical to the Barnwell case except that one less evaporator and condenser vent to it resulting in less water and nitric acid vapor. Dissolver and vessel off-gas streams are treated by the scheme described earlier for the Barnwell plant.

The degraded solvent burner and excess water vaporizer (EWV) are both similar to those in the Barnwell plant. Quench water from the burner and bottoms from the EWV, to which mercuric nitrate has been added, are both likely to contain iodine and are therefore routed to the cement plant to avoid re-volatilization upon vitrification.

Waste Vitrification System. The high-level liquid waste stream is handled by the waste vitrification system. The system flowsheet, based upon development work in progress at PNL (reference 16), consists of calcination, vitrification, canister handling and effluent treatment.

- Calcination. The spray calciner decomposes the chemicals in the riquid waste to a calcine powder of metal oxides and process off gas. HLLW from the interim storage tank is transferred to the calciner feed tank and pumped through an internal-mixing pneumatic atomizing nozzle at the top of the spray drying chamber. The fine waste droplets leaving the nozzle are dried and calcined to an oxide powder as they fall through a cylindrical chamber with its wall heated to $700^{\circ} \mathrm{C}$ by a multizone electrical resistance-heated furnace. The oxide powder falls out of the bottom of the spray dryer at a temperature of about $300^{\circ} \mathrm{C}$. 
Granular glass frit is metered into the cone at the calciner bottom at a rate proportional to the feed rate to the calciner. For BNFP wastes, one part by weight of HLLW and ILLW calcine is added to about two parts of frit and dropped down a loading chute into a canister for melting. When one canister is full, a diverter valve routes the calcine-frit mix to a second preheated canister.

- Vitrification. The mixture of waste powder and frit falls through a flow diverter valve, into a $304 \mathrm{~L}$ stainless steel canister contained in the retort (secondary container) of one of the two multizoned electrical resistance heated melter furnaces. The mixture is heated to melting at about $1050^{\circ} \mathrm{C}$. As the melt level rises, heating of the furnace zones below the melt level is terminated and cooling air is blown on the outer wall of the retorts, cooling the glass to temperatures below $800^{\circ} \mathrm{C}$. During the filling of the waste canister with glass, the space between the retort and the canister is purged with an inert gas such as argon to reduce oxidation of the canister.

- Canister Handling. The filled and cooled canister is removed from the calciner connections and a lid is placed on the canister. A prepackaged helium source is placed in the canister prior to closure to provide helium for later leak testing. The filled canister is moved to the seal welding and inspection station.

The canister lid is seal welded with an automatic welder using the Tungsten Inert Gas process. The canister weld is helium leak checked with a mass spectrometer and the canister is visually inspected for flaws or damage. The external surfaces of the filled canister are then decontaminated with medium pressure water and/or steam sprays to remove loose contamination. The canister is then moved to interim storage in the air-cooled racks in the Waste Vitrification Cell before being transferred to the fuel storage water pool in the Fuel Recovery and Storage Station for temporary storage and shipment offsite to a Federal repository. 
- Effluent Treatment. The primary sources of process effluents are calciner and melter off gas, canister cooling air, retort purge gas and canister decontamination solution. Other effluents from the process area include cell ventilation air, vessel ventilation air and solutions from periodic process cell chemical decontamination.

Airborne effluents from the waste solidification process can be treated separately or combined, after pretreatment, with $\mathrm{U} / \mathrm{Pu}$ calcination and dissolver off gas for recovery of $\mathrm{NO}_{x}$ as nitric acid. The combined calciner and melter off gas is filtered by sintered stainless steel filters to remove bulk entrained calcine. Less than 0.1 weight percent (wt\%) of the calcine passes through the filters. About $2 \%$ of the fission product ruthenium is volatilized and escapes the calciner as does most of any tritium and halogens (i.e., fluorine, bromine, chlorine and iodine) reaching the calciner. The balance of the radionculides remain in the calcine. The calcine filters are periodically blown back with air pulses to remove the accumulation of calcine dusts.

The calciner off gas from the sintered stainless filters is subjected to a series of process operations to remove particulates, volatized ruthenium, halogens and other condensible gases, and $\mathrm{NO}_{x}$. These off-gas treatment steps include:

1. quenching in a high energy venturi scrubber to cool the gases and remove particulates,

2. condensing, together with U/Pu calcination off gases, to separate the condensible gases and aerosols from noncondensible gases; condensate is sent to the HLLW concentrator,

3. mist elimination to further remove aerosols from noncondensible gases, and

4. adsorption to remove most of the remaining ruthenium from noncondensible gases.

The pretreated off gas is then either routed to the $\mathrm{NO}_{\mathrm{x}}$ absorber in the dissolver off-gas system or, if that system is off line, subjected to the following steps: 
1. HEPA filtration to further remove aerosols from noncondensible gases,

2. removal of iodine and other halogens from noncondensible gases by adsorption on silver zeolite, and

3. destruction of $\mathrm{NO}_{x}$ in the noncondensible gases by passing through a heated catalyst in the presence of excess ammonia.

The canister cooling air and the retort purge inert gas are vented to the cell, combined with the cell ventilation air and filtered to remove radioactive particulates before release to the final filtration system for the fuel reprocessing plant. The cell air filtration system includes one stage of roughing filters followed by two stages of HEPA filters. The treated vessel off gases are combined with the cell ventilation air for final treatment in the ventilation filter station and release through the main stack.

Some cell or equipment decontamination is required periodically during production operations. Typical solutions used include steam, water, nitric acid, caustic, potassium permanganate and tartaric acid. These solutions are collected in the cell sump and process tanks, transferred to a waste accumulation tank for sampling, and combined with the HLLW.

Cement Plant. The cement plant handles wastes containing volatile species such as Ru and I which might re-volatilize in the high temperature vitrification process. Various alternatives for cement immobilization of low level waste are outlined in TAD (reference 8, p.12.13).

\section{C.2.3 Effluents}

This section describes the performance of the off-gas systems for waste management operations at the coprocessing facility. This section is written in support of Section 5.2.2.2 which characterizes the coprocessing plant effluents.

Listed in Table C.9 are the types of off-gas filtration equipment utilized in the fuel coprocessing facility. An estimated decontamination factor ( $D F$ ) is listed for ${ }^{3} \mathrm{H}, \mathrm{I}, \mathrm{Ru}-\mathrm{Rh}$, and all other species present. These four isotopic classed are chosen because of chemical and physical similarities, radioactivity significance and environmental significance. 
TABLE C.9. Off-Gas System Performance Specifications

\begin{tabular}{|c|c|c|c|c|}
\hline $\begin{array}{l}\text { Off-Gas } \\
\text { System }\end{array}$ & \multicolumn{4}{|c|}{ Decontamination Factor } \\
\hline & $\underline{3_{H}}$ & $\underline{I}$ & Ru-Rh & Others \\
\hline Screen \& condenser & 10 & 1 & 5 & 100 \\
\hline Condenser & 10 & 1 & 1 & 1 \\
\hline 1-I scrubber & 1 & 10 & 1 & 1 \\
\hline 2-I scrubbers & 1 & $10^{3}$ & 1 & 1 \\
\hline Ru absorber & 1 & 1 & $10^{3}$ & 1 \\
\hline $\mathrm{NO}_{\mathrm{X}}$ destructor & 1 & 1 & 1 & 1 \\
\hline Roughing \& HEPA filter & 1 & 1 & 100 & $10^{4}$ \\
\hline Roughing \& 2 HEPAS & 1 & 1 & 100 & $10^{7}$ \\
\hline Each additional HEPA & 1 & 1 & 100 & $10^{3}$ \\
\hline 2 HEPAS & 1 & 1 & 100 & $10^{6}$ \\
\hline GPC/EWV $(a)$ & 1 & 1 & 100 & $10^{6}$ \\
\hline Venturi & 1 & 1 & 1 & 10 \\
\hline
\end{tabular}

\section{C.2.3.1 High-Level Liquid Waste}

The off-gas system for the high-level liquid waste vitrification facility includes the following components:

- venturi

- screen and condenser

- Ru absorber

- $\mathrm{NO}_{\mathrm{x}}$ destructor

- 2-I scrubbers

- roughing and HEPA filter

- two HEPA filters

The release fractions of high-level liquid waste to off gas is defined as that fraction of input radioactivity which goes to off gas. The release fractions for ${ }^{3} \mathrm{H}, \mathrm{I}$, Ru-Rh and others are, respectively, $1,1,10^{-4}$ and $5 \times 10^{-6}$. (17) 


\section{C.2.3.2 General Trash}

TRU Trash Incineration. Radioactive effluents evolve from three sources in this process: incineration, blowdown concentration and cementation. Diagrammed in Figure C.6 is the flow of radionuclides in the TRU waste incineration and cementation system. (18)

Non-TRU Trash Compaction. The non-TRU trash compaction off gas is filtered by a roughing and three HEPA filters, resulting in a particulate DF of $10^{10}$. The release fraction of input radioactivity to off gas is estimated to be $1 \times 10^{-4}$. (18)

TRU HEPA Filter Packaging. The TRU HEPA filter packaging off gas is fil tered by a roughing and three HEPA filters prior to release to the environment, resulting in a $D F$ of $10^{10}$ for particulates. The release fraction is estimated to be $1 \times 10^{-4}$. (18)

Non-TRU HEPA Filter Packaging. The filtration system, overall DF and release fraction for non-TRU HEPA filter packaging is the same as for TRU filters.

\section{C.2.3.3 Wet Waste}

The off-gas system for the cementation process consists of an iodine scrubber, a roughing filter and three HEPA filters, resulting in an overall particulate DF of $10^{10}$. The release fraction of radioactivity from the cement process is estimated to be $10^{-6} \cdot(19,20)$

\section{C.2.3.4 Scrap}

The process off-gas filtration system for both TRU and non-TRU scrap packaging consists of a roughing filter and three HEPA filters resulting in a particulate DF of $10^{10}$. The release fraction from waste processing is estimated to be $1 \times 10^{-5}$. (21)

\section{C.2.3.5 Main Plant Off Gas}

The main plant off gas consists of seven individual waste streams, as discussed in Sections 4.2.3 and 4.2.4. The filtration elements for each contributing stream are listed below. The indices are calculated only for the composite effluent. 


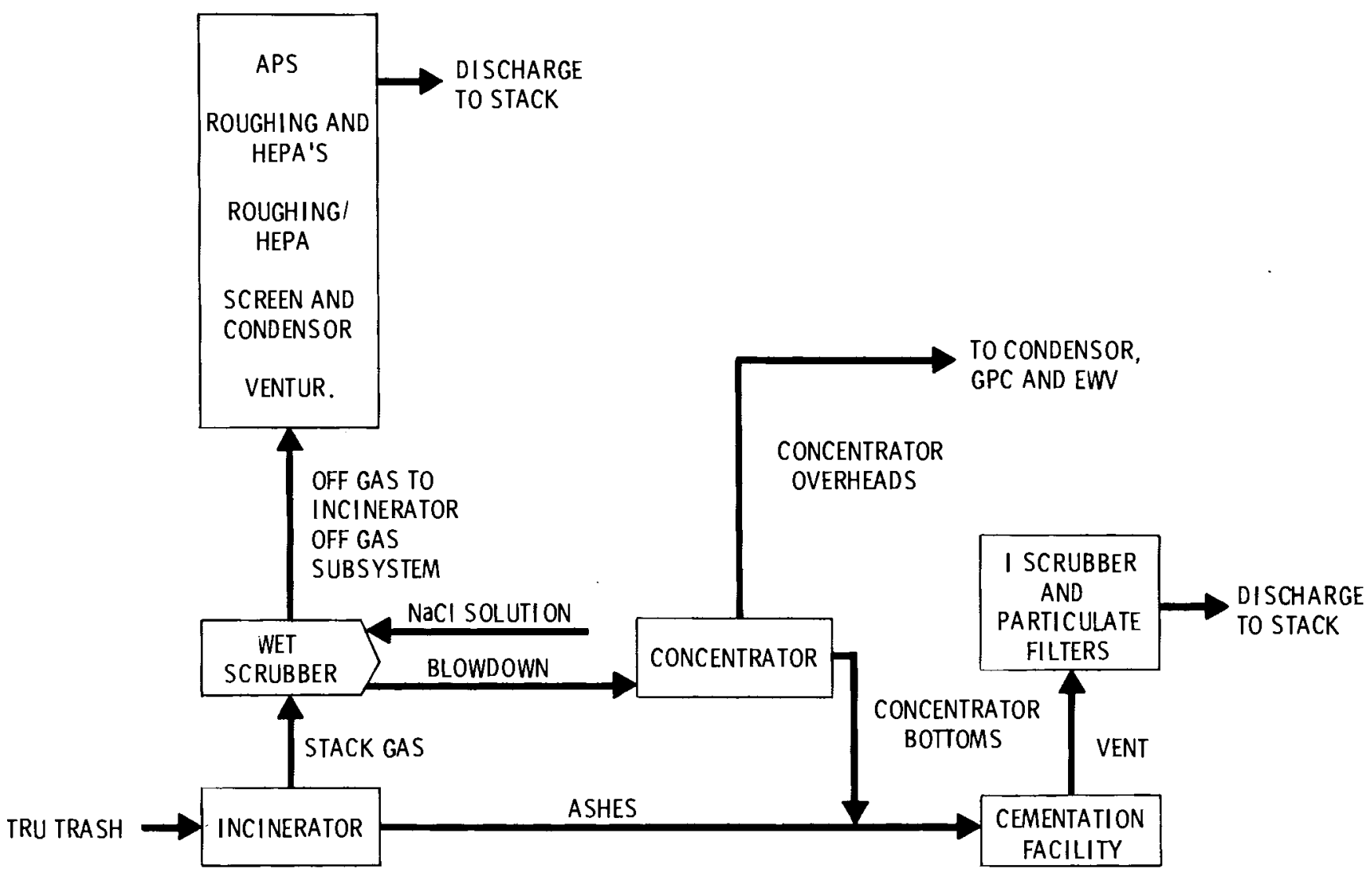

\begin{tabular}{|c|c|c|c|c|}
\hline \multirow{2}{*}{$\begin{array}{l}\text { RADIOACTIVITY } \\
\text { GROUP } \\
\end{array}$} & \multicolumn{4}{|c|}{ FRACTI ON OF INPUT RADIOACTIVITY RELEASED TO THE ENVIRONMENT } \\
\hline & INCINERATOR STACK GAS & CONCENTRATOR & CEMENTATION & TOTAL \\
\hline $3 \mathrm{H}$ & 0.21 & 0.71 & -.. & 0.92 \\
\hline 1 & 0.52 & 0.47 & $1 \times 10^{-6}$ & 0.99 \\
\hline Ru-Rh & $9 \times 10^{-15}$ & $1 \times 10^{-11}$ & $1 \times 10^{-16}$ & $1 \times 10^{-11}$ \\
\hline OTHERS & $2 \times 10^{-15}$ & $2 \times 10^{-12}$ & $1 \times 10^{-16}$ & $2 \times 10^{-12}$ \\
\hline
\end{tabular}

FIGURE C.6. Off-Gas System for TRU Waste Incineration and Cementation 
The filtration elements at the fuel shear and dissolver off gas are:

- screen and condenser

- 2-I scrubber

- $\mathrm{NO}_{\mathrm{x}}$ destructor

- condenser

- roughing and HEPA filters

- I absorber

- 2-HEPA filters

The overall DF's for ${ }^{3} \mathrm{H}$, I, Ru-Rh and others for this system are, respectively, $10^{2}, 10^{4}$ and $10^{12}$.

The vessel off-gas filtration elements are:

- 2-I absorbers

- roughing and HEPA filters

- 2-HEPA filters

The overall DF's for ${ }^{3} \mathrm{H}, \mathrm{I}, \mathrm{Ru}-\mathrm{Rh}$, and others are, respectively, $10,10^{3}$, $5 \times 10^{4}$ and $10^{12}$.

The filtration elements for the main building and storage basin HVAC are a roughing filter and 2 HEPA filters. The DF's for ${ }^{3} \mathrm{H}, \mathrm{I}, \mathrm{Ru}-\mathrm{Rh}$, and others are, respectively, $1,1,10^{2}$, and $10^{7}$.

Excess water is evaporated through the general purpose concentrator and excess water vaporizer, and is discharged as water vapor. The DF's for ${ }^{3} \mathrm{H}, \mathrm{I}$, $\mathrm{Ru}-\mathrm{Rh}$ and others are, respectively, $1,1,10^{2}$, and $10^{6}$.

The filtration elements for the $U_{6}$ plant process off gas are a roughing filter and three HEPA filters. The DF's for ${ }^{3} \mathrm{H}, \mathrm{I}, \mathrm{Ru}-\mathrm{Rh}$ and others are, respectively, $1,1,10^{4}$ and $10^{10}$.

The off gas from the mixed-nitrate calciner is filtered through the following elements:

- screen and condenser

- Ru absorber

- roughing and HEPA filters 
- 2-I scrubbers

- ${ }^{\mathrm{N} O} \mathrm{x}$ destructors

- roughing and 2-HEPA filters

The DF's for ${ }^{3} \mathrm{H}, \mathrm{I}, \mathrm{Ru}-\mathrm{Rh}$ and other particulates through this system are, respectively, $10,10^{3}, 5 \times 10^{7}$ and $10^{12}$.

\section{C.2.4 Summary}

Significant differences occur between the reference coprocessing flowsheet and the PUREX process stem because of the intentionally incomplete decontamination of the plutonium product. Although the volumes and activities of major waste streams are similar, high activity must be handled in oxide conversion and fuel refabrication steps which, in the PUREX process, are contaminated only by the presence of plutonium. Specific examples of resulting inputs to waste management are Ru volatilized in U/Pu calcination and Cs volatilized in MOX fuel sintering. In addition, all of the fuel contaminated wastes from the oxide conversion and refabrication steps contain significant gamma activity in addition to the alpha and beta activity from plutonium found in analogous wastes from the PUREX process. Since the MOX fabrication plant is located separately from the separations facility, use of the coprocessed fuel cycle will result in the generation of gamma emitting wastes at a new location. This facility will be modified to process these wastes.

\section{C.3 WASTE DEFINITIONS}

The wastes expected to be generated in the coprocessed $\mathrm{UO}_{2}-\mathrm{PuO}_{2}$ fuel cycle are tabulated below. Reactor wastes are presented elsewhere. Separations facility and mixed-oxide fuel fabrication facility wastes are listed on a metric ton heavy metal (MTHM) basis. Radioactivity in the wastes will be defined as fractions of hull and hardware fission products and actinide radioisotopes as listed in Tables C.2, C.3, C.4 and C.6. Constants usefur in determining total fuel cycle wastes are: 1) 34.2 MTHM of spent fuel received and processed at a separation facility is equivalent to 1 GWe-yr of energy generation; and 2) in a forward accounting system, 6.8 MTHM of MOX fuel fabricated is equivalent to 1 GWe-yr. The wastes listed below are mostly excerpted from reference 6 , as modified for the specific case, and to account for the differences 
between coprocessing and reprocessing wastes. Coprocessing plant radioactive wastes are tabulated in Tables C.10 through C.17, while MOX plant wastes are tabulated in Tables C.18 through C.21. Tables C.11, C.15 and C.17 are taken from reference 6 without change. The remainder have been changed according to the fuel cycle flow information presented in Section 2.

\section{C.4 WASTE PROCESSES}

The radioactive wastes generated in the coprocessed $\mathrm{UO}_{2}-\mathrm{PuO}_{2}$ fuel cycle are assumed to be treated using nuclear waste processing technology which is readily available. This section describes each processing technology selected, excluding nuclear power plant waste processing which is described elsewhere.

\section{C.4.1 Fuel Coprocessing Facility Waste Treatment}

The overall radioactive waste treatment and disposal strategy for the fuel coprocessing facility wastes is shown in Figure C.7. Each waste stream is discussed below. All wastes, except for the high-level wastes, may be stored onsite for three months in treatment surge areas.

- High-level liquid waste is immobilized by calcination and vitrification with in-can melting. A surge tank system is provided to hold 15 plantdays of high-level liquid waste. The surge system consists of a 300gallon routing tank and three 10,000-gallon titanium tanks. All equipment is remote and located within hot cells, including the surge tanks (see Section 7.3.7 of reference 22 for a comprehensive description of the surge tank system). The waste is immobilized in stainless steel canisters that are 12 inches in diameter and 10 feet long. Following immobilization, the canisters are stored for 5 years in an onsite water basin with forced cooling. Detailed descriptions and discussion of the calcination/vitrification facility and the storage facility may be found in references 16 , 17 and 23-30. 
TABLE C.10. Gaseous Waste from Coprocessing Plant

\begin{tabular}{|c|c|c|c|c|c|c|c|c|}
\hline \multirow{3}{*}{$\begin{array}{l}\text { Source } \\
\text { Fuet shear and } \\
\text { dissolver off gas }\end{array}$} & \multicolumn{2}{|c|}{$\begin{array}{c}\text { Components, } \\
(w t \%)\end{array}$} & \multirow{2}{*}{$\begin{array}{c}\begin{array}{c}\text { Density } \\
\left(\mathrm{kg} / \mathrm{m}^{3}\right)\end{array} \\
1.22\end{array}$} & \multirow{2}{*}{$\frac{\begin{array}{c}\text { Volume } \\
\left(\mathrm{m}^{3} / \mathrm{MTHM}\right)\end{array}}{2.1 \times 10^{3}}$} & \multicolumn{4}{|c|}{ Rądjonuclide Content } \\
\hline & $\mathrm{H}_{2} \mathrm{O}$ & 5.4 & & & ${ }^{3} \mathrm{H}$ & $5 \times 10^{-2}$ & & $5 \times 10^{-4}$ \\
\hline & $\mathrm{NO}_{2}$ & 2.0 & & & ${ }^{14} \mathrm{C}$ & 1.0 & & \\
\hline & NO & 2.3 & & & $\mathrm{Kr}, \mathrm{Xe}$ & 1.0 & & \\
\hline & $\mathrm{N}_{2}$ & 68 & & & I & 0.9 & & \\
\hline & $\mathrm{O}_{2}$ & 22 & & & All others & $5 \times 10^{-4}$ & & \\
\hline Vessel off gas & $\mathrm{H}_{2} \mathrm{O}$ & 17.3 & 1.22 & $1.7 \times 10^{4}$ & ${ }^{3} \mathrm{H}$ & $8 \times 10^{-6}$ & $\mathrm{~Np}$ & $4.6 \times 10^{-5}$ \\
\hline & $\mathrm{HNO}_{3}$ & 1.0 & & & I & $3 \times 10^{-6}$ & U & $1.9 \times 10^{-4}$ \\
\hline & $\mathrm{N}_{2}$ & 61.5 & & & $\mathrm{Zr}-\mathrm{Nb} / \mathrm{Ru}-\mathrm{Rh}$ & $5.6 \times 10^{-5}$ & $\mathrm{Pu}$ & $1 \times 10^{-3}$ \\
\hline & $\mathrm{O}_{2}$ & 20.9 & & & All others & $1.5 \times 10^{-5}$ & All others & $1.5 \times 10^{-5}$ \\
\hline & $\mathrm{CO}_{2}$ & 0.3 & & & & & & \\
\hline & $\mathrm{H}_{2}$ & 0.004 & & & & & & \\
\hline $\begin{array}{l}\text { Main Building } \\
\text { HVAC }\end{array}$ & Air & 100 & 1.22 & $1.8 \times 10^{6}$ & & $1 \times 10^{-11}$ & & $1 \times 10^{-11}$ \\
\hline Excess Water & $\mathrm{H}_{2} \mathrm{O}$ & 100 & $6 \times 10^{-1}$ & $2 \times 10^{4}$ & ${ }^{3} \mathrm{H}$ & 0.835 & $\mathrm{~Np}$ & $4 \times 10^{-9}$ \\
\hline & & & & & I & $3 \times 10^{-4}$ & U & $9 \times 10^{-8}$ \\
\hline & & & & & $\mathrm{Zr}-\mathrm{Nb} / \mathrm{Ru}-\mathrm{Rh}$ & $3.5 \times 10^{-8}$ & $\mathrm{Pu}$ & $1.2 \times 10^{-9}$ \\
\hline & & & & & All Others & $2.5 \times 10^{-9}$ & Al1 Others & $2.5 \times 10^{-9}$ \\
\hline
\end{tabular}

(a) Given as fractions of curie values listed in Table C.3 (b) Given as fractions of curie values listed in Table C.2. 
TABLE C.10. (cont'd)

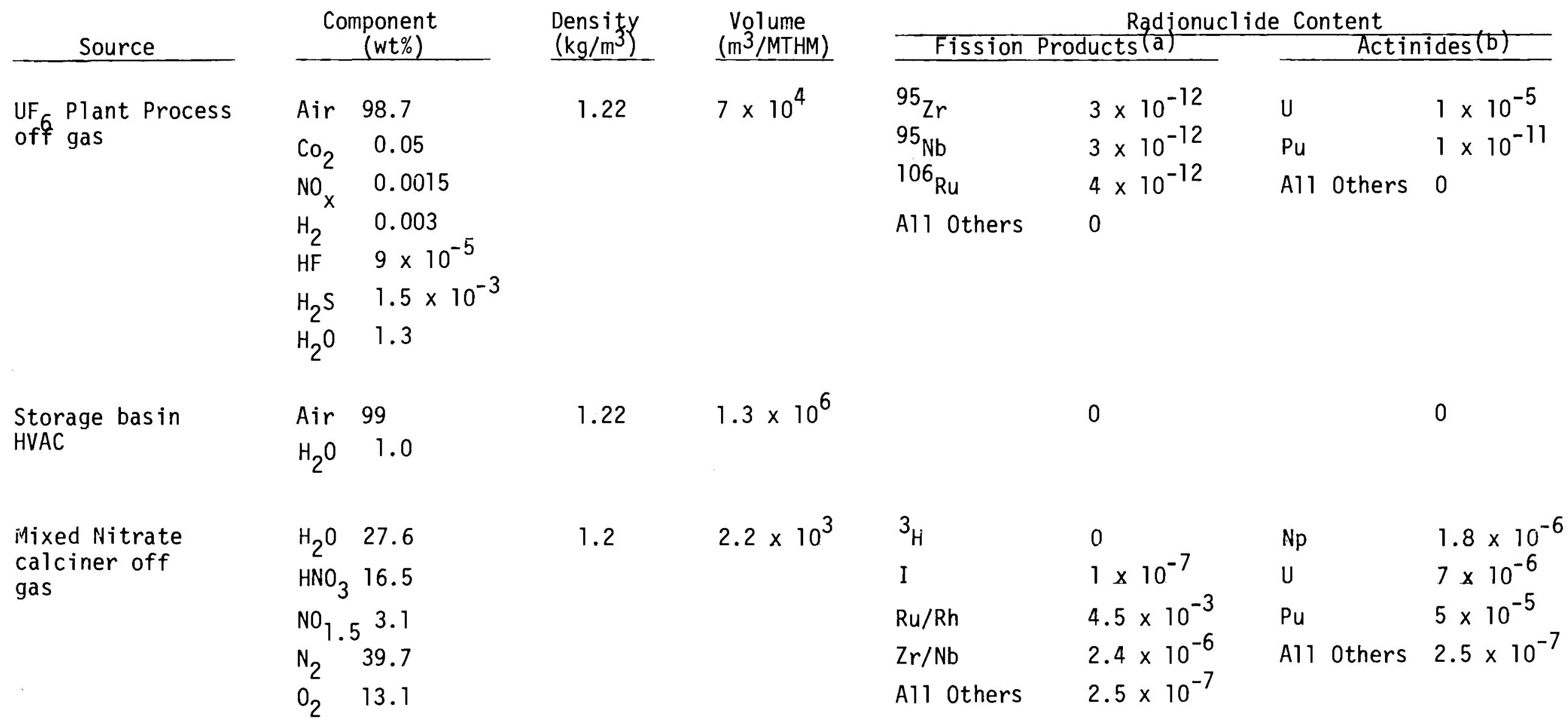

(a) Given as fractions of curie values listed in Table C.3

(b) Given as fractions of curie values listed in Table C.2. 
TABLE C.11. Hulls and Assembly Hardware from Coprocessing Plant

\begin{tabular}{|c|c|c|c|c|c|c|c|}
\hline \multirow[b]{2}{*}{ Source } & \multirow{2}{*}{\multicolumn{2}{|c|}{$\begin{array}{c}\text { Components } \\
(w t \%)\end{array}$}} & \multirow[b]{2}{*}{$\begin{array}{l}\text { Density } \\
\left(\mathrm{kg} / \mathrm{m}^{3}\right)\end{array}$} & \multirow[b]{2}{*}{$\begin{array}{l}\text { Weight } \\
\text { (kg/MTHM) }\end{array}$} & \multicolumn{3}{|c|}{ Radionuclide Content } \\
\hline & & & & & $\begin{array}{l}\text { Activation } \\
\text { Products }\end{array}$ & Fission Products(b) & Actinides $(c)$ \\
\hline \multirow[t]{5}{*}{ Hardware } & $\mathrm{Fe}$ & 57 & $1 \times 10^{3}$ & $5.6 \times 10^{1}$ & $1.0^{(\mathrm{a})}$ & 0 & 0 \\
\hline & $\mathrm{Ni}$ & 17 & & & & & \\
\hline & $\mathrm{Cr}$ & 17 & & & & & \\
\hline & $\mathrm{Cu}$ & 5 & & & & & \\
\hline & $\begin{array}{l}\text { Other } \\
\text { metals }\end{array}$ & 4 & & & & & \\
\hline
\end{tabular}

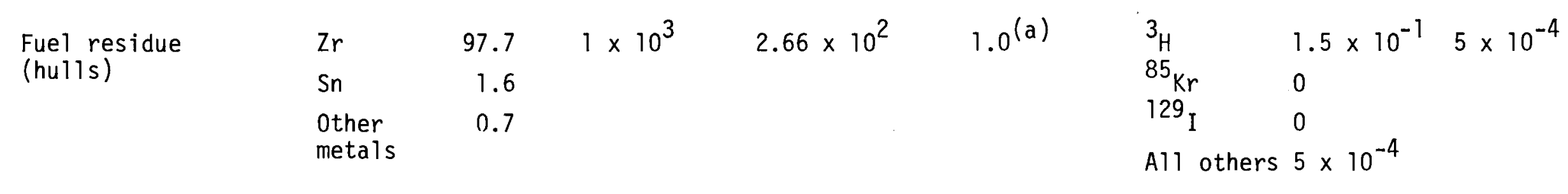

(a) Given as fraction of $\mathrm{Ci}$ values listed in Table C.4
(b) Given as fraction of $\mathrm{Ci}$ values listed in Table C.3
(c) Given as fraction of $\mathrm{Ci}$ values listed in Table C.2 
TABLE C.12. High-Level Liquid Waste from Coprocessing Plant

\begin{tabular}{|c|c|c|c|c|c|c|c|c|}
\hline Source & Compor & & $\begin{array}{l}\text { Density } \\
\left(\mathrm{ka} / \mathrm{m}^{3}\right)\end{array}$ & $\begin{array}{c}\text { Volume } \\
\text { (m } 3 \text { /MTHM) }\end{array}$ & Fission $P$ & $\frac{\text { Rądjonuc }}{\text { ducts }}$ & $\frac{\text { Content }}{\text { Actin }}$ & $\overline{e s}(t)$ \\
\hline $\begin{array}{l}\text { Concentrated } \\
\text { Raffinate from }\end{array}$ & $\begin{array}{l}\text { Nitrate } \\
\text { salts }\end{array}$ & 15 & $1.2 \times 10^{3}$ & $7.1 \times 10^{-1}$ & $3_{H}$ & $6.8 \times 10^{-2}$ & $U$ & $2 \times 10^{-3}$ \\
\hline $\begin{array}{l}\text { first cycle ex- } \\
\text { tractor, dissolver }\end{array}$ & $\mathrm{HNO}_{3}$ & 10 & & & $\mathrm{Kr}, \mathrm{Xe}$ & 0 & $\mathrm{Pu}$ & $5 \times 10^{-3}$ \\
\hline sludge and general & $\mathrm{H}_{2} \mathrm{O}$ & 75 & & & I & $3 \times 10^{-7}$ & $\mathrm{~Np}$ & 0.97 \\
\hline $\begin{array}{l}\text { purpose concentra- } \\
\text { tor bottoms }\end{array}$ & & & & & $\mathrm{Zr}-\mathrm{Nb} / \mathrm{Ru}-\mathrm{Rh}$ & 0.95 & All Others & 1.0 \\
\hline & & & & & A11 Others & 1.0 & & \\
\hline
\end{tabular}

(a) Given as fraction of $\mathrm{C} i$ values listed in Table C.3

(b) Given as fraction of $\mathrm{C} i$ values listed in Table C.2 


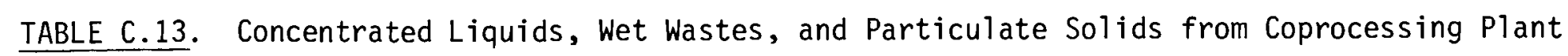

\begin{tabular}{|c|c|c|c|c|c|c|}
\hline \multirow{3}{*}{$\begin{array}{l}\text { Source } \\
\\
\text { Main plant } \\
\text { silica ge } \text { (TRU) }\end{array}$} & \multicolumn{2}{|c|}{$\begin{array}{c}\text { Components } \\
(w t \%)\end{array}$} & \multirow{3}{*}{$\frac{\begin{array}{l}\text { Densitzy } \\
\left(\mathrm{kg} / \mathrm{m}^{3}\right)\end{array}}{8 \times 10^{2}}$} & \multirow{2}{*}{$\frac{\begin{array}{c}\text { Volume } \\
\left(\mathrm{m}^{3} / \text { MTHM }\right)\end{array}}{5 \times 10^{-3}}$} & \multicolumn{2}{|r|}{$\frac{\text { Radjonu }}{\text { roducts }}$} \\
\hline & $\mathrm{SiO}_{2}$ & 70 & & & $\mathrm{Zr}$ & $1 \times 10^{-7}$ \\
\hline & $\mathrm{H}_{2} \mathrm{O}^{2}$ & 30 & & & $\mathrm{Nb}$ & $1 \times 10^{-7}$ \\
\hline & & & & & All others & 0 \\
\hline \multirow{2}{*}{$\begin{array}{l}\text { Storage basin } \\
\text { bead resins } \\
\text { (non-TRU) }\end{array}$} & Resin & 50 & $7.2 \times 10^{2}$ & $2 \times 10^{-3}$ & & $3 \times 10^{-3(c)}$ \\
\hline & $\mathrm{H}_{2} \mathrm{O}$ & 50 & & & & \\
\hline \multirow{2}{*}{$\begin{array}{l}\text { Storage basin } \\
\text { filter precoat } \\
\text { sludge (non-TRU) }\end{array}$} & Sludge & 40 & $4.3 \times 10^{2}$ & $7 \times 10^{-3}$ & & $3 \times 10^{-1(c)}$ \\
\hline & $\mathrm{H}_{2} \mathrm{O}$ & 60 & & & & \\
\hline \multirow{2}{*}{$\begin{array}{l}\text { Storage basin } \\
\text { sulfate concen- } \\
\text { trate (non-TRU) }\end{array}$} & $\mathrm{Na}_{2} \mathrm{SO}_{4}$ & 25 & $1.21 \times 10^{3}$ & $5 \times 10^{-3}$ & & $3 \times 10^{-1(c)}$ \\
\hline & & 75 & & & & \\
\hline \multirow{2}{*}{$\begin{array}{l}\text { Storage basin } \\
\text { miscellaneous solu- } \\
\text { tions (non-TRU) }\end{array}$} & Salts & 25 & $1.2 \times 10^{3}$ & $1 \times 10^{-2}$ & & $4 \times 10^{-1(c)}$ \\
\hline & $\mathrm{H}_{2} \mathrm{O}$ & 75 & & & & \\
\hline
\end{tabular}

\begin{tabular}{ll} 
Actinides $(\mathrm{b})$ & \multicolumn{2}{c}{$1 \times 10^{-7}$} \\
$\mathrm{Pu}$ & $1 \times 1$
\end{tabular}
(a) Given as fraction of $\mathrm{C} i$ values listed in Table $C .3$
(b) Given as fraction of $\mathrm{C} i$ values listed in Table $C .2$
(c) Given as fraction of $\mathrm{Ci}$ values listed in Table C.6, including activation products 
TABLE C.13. (cont'd)

\begin{tabular}{|c|c|c|c|c|c|c|c|c|}
\hline \multirow{4}{*}{$\begin{array}{l}\text { Source } \\
\begin{array}{l}\text { UF } \\
\text { nator blant fluori- } \\
\text { (TRU) }\end{array}\end{array}$} & \multirow{2}{*}{\multicolumn{2}{|c|}{$\begin{array}{c}\text { Components } \\
(w t \%)\end{array}$}} & \multirow{4}{*}{$\begin{array}{l}\begin{array}{l}\text { Density } \\
\left(\mathrm{kg} / \mathrm{m}^{3}\right)\end{array} \\
1.5 \times 10^{3}\end{array}$} & \multirow{4}{*}{$\begin{array}{c}\begin{array}{c}\text { Volume } \\
(\mathrm{m} 3 / \mathrm{MTHM})\end{array} \\
4 \times 10^{-3}\end{array}$} & \multicolumn{4}{|c|}{ onuclide Content } \\
\hline & & & & & \multicolumn{2}{|c|}{ Fission Products(a) } & \multicolumn{2}{|c|}{ Actinides $(b)$} \\
\hline & $\mathrm{Al}_{2} \mathrm{O}_{3}$ & 100 & & & $3_{H}$ & 0 & $U$ & $6 \times 10^{-6}$ \\
\hline & & & & & ${ }^{85} \mathrm{Kr}$ & 0 & $\mathrm{Pu}$ & $2 \times 10^{-7}$ \\
\hline & & & & & ${ }^{129} \mathrm{I}$ & 0 & All others & 0 \\
\hline & & & & & $\mathrm{Zr}$ & $1 \times 10^{-8}$ & & \\
\hline & & & & & $\mathrm{Nb}$ & $1 \times 10^{-8}$ & & \\
\hline & & & & & $\mathrm{Ru}$ & $1 \times 10^{-7}$ & & \\
\hline & & & & & All others & 0 & & \\
\hline \multirow{4}{*}{$\begin{array}{l}U_{6} \text { plant fluori- } \\
\text { nator fines (TRU) }\end{array}$} & $\mathrm{Al}_{2} \mathrm{O}_{3}$ & 50 & $1.5 \times 10^{3}$ & $3 \times 10^{-2}$ & $\mathrm{Zr}$ & $1 \times 10^{-7}$ & $u$ & $1.5 \times 10^{-3}$ \\
\hline & $\mathrm{CaF}_{2}$ & 46 & & & $\mathrm{Nb}$ & $1 \times 10^{-7}$ & $\mathrm{Pu}$ & $1 \times 10^{-6}$ \\
\hline & Uranium & 4 & & & $\mathrm{Ru}$ & $1 \times 10^{-6}$ & A11 others & 0 \\
\hline & fluorides & & & & A11 others & 0 & & \\
\hline \multirow{6}{*}{$\begin{array}{l}U_{6} \text { plant } \mathrm{K}_{2} U \mathrm{O}_{4} \\
\text { mud }(\text { non-TRU) }\end{array}$} & $\mathrm{KOH}$ & 3 & $1.2 \times 10^{3}$ & $7 \times 10^{-2}$ & & 0 & U & $1.3 \times 10^{-3}$ \\
\hline & $\mathrm{KF}$ & 4 & & & & & A11 others & 0 \\
\hline & $\mathrm{K}_{2} \mathrm{UO}_{4}$ & 3 & & & & & & \\
\hline & $\mathrm{Fe}(\mathrm{OH})_{2}$ & 18 & & & & & & \\
\hline & Misc. sal & & & & & & & \\
\hline & $\mathrm{H}_{2} \mathrm{O}$ & 71 & & & & & & \\
\hline
\end{tabular}

(a) Given as fraction of $\mathrm{Ci}$ values listed in Table C.3

(b) Given as fraction of $\mathrm{Ci}$ values listed in Table C.2 
TABLE C.13. (cont'd)

\begin{tabular}{|c|c|c|c|c|}
\hline \multirow{3}{*}{ 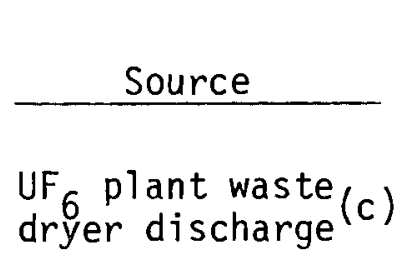 } & \multicolumn{2}{|c|}{$\begin{array}{c}\text { Components } \\
(w t \%)\end{array}$} & \multirow{2}{*}{$\begin{array}{l}\begin{array}{l}\text { Density } \\
\left(\mathrm{kg} / \mathrm{m}^{3}\right)\end{array} \\
5 \times 10^{2}\end{array}$} & \multirow{2}{*}{$\begin{array}{c}\begin{array}{c}\text { Volume } \\
\text { (m3/MTHM) }\end{array} \\
5 \times 10^{-1}\end{array}$} \\
\hline & $\mathrm{CaF}_{2}$ & 62 & & \\
\hline & $\mathrm{Ca}(\mathrm{OH})_{2}$ & 15 & & \\
\hline & $\mathrm{CaSO}_{4}$ & 8 & & \\
\hline & $\mathrm{KOH}{ }^{+}$ & 12 & & \\
\hline & $\mathrm{KF}$ & 2 & & \\
\hline & Misc. Si & & & \\
\hline
\end{tabular}

Radionuclide Content Fission Products $(a)$

(a) Given as fraction of $\mathrm{C} i$ values listed in Table $C .3$

(b) Given as fraction of $\mathrm{C} i$ values listed in Table $\mathrm{C} .2$

(c) Treated as nonradioactive waste. 
TABLE C.14. Intermediate-Level Compactable Trash and Combustible Waste from Coprocessing Plant

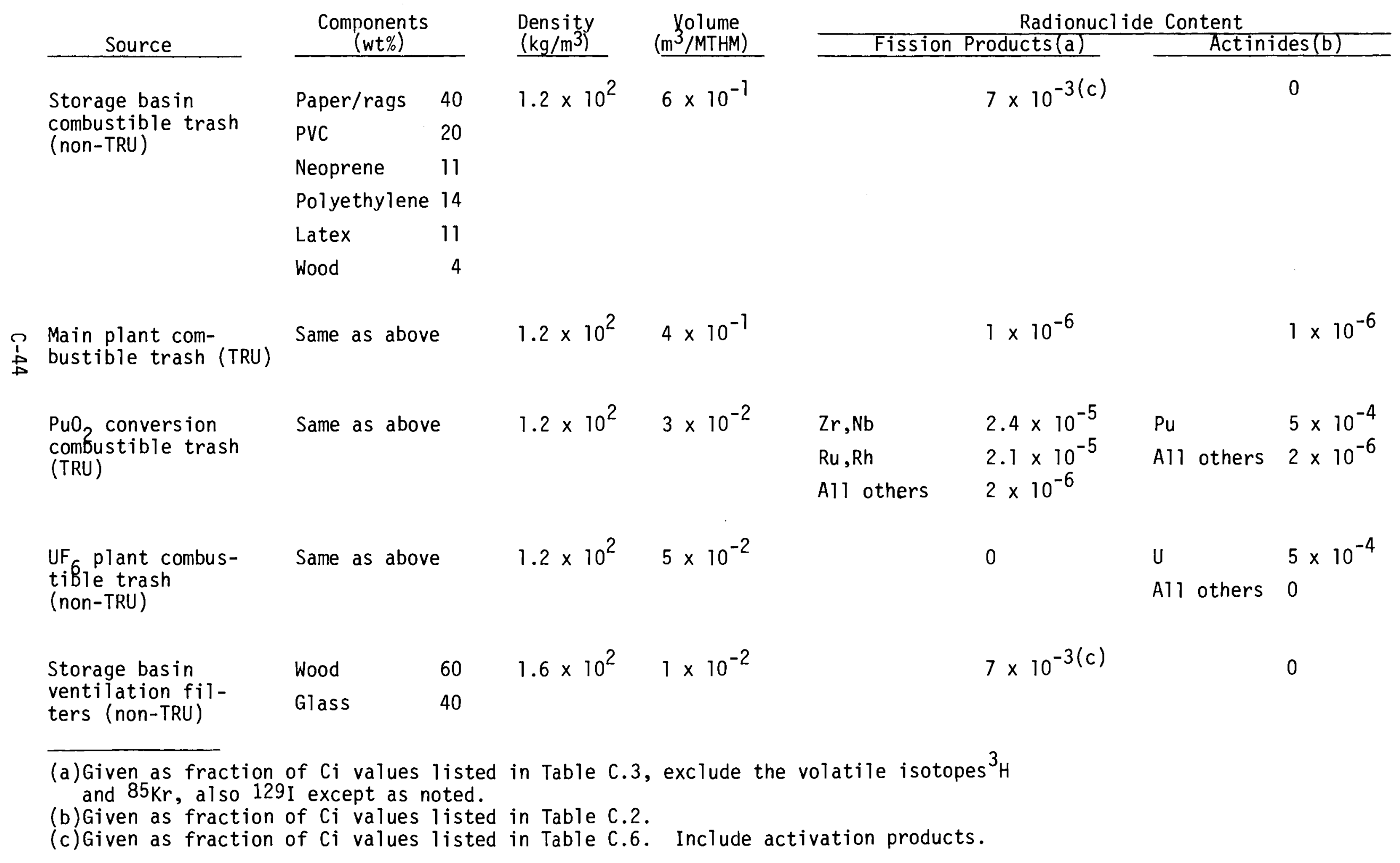


TABLE C.14. (cont'd)

\begin{tabular}{|c|c|c|c|c|c|c|c|c|}
\hline cauno & \multicolumn{2}{|c|}{$\begin{array}{c}\text { Comnonents } \\
(w t \%)\end{array}$} & \multirow{2}{*}{$\frac{\begin{array}{l}\text { Density } \\
(\mathrm{kg} / \mathrm{m})\end{array}}{1.6 \times 10^{2}}$} & \multirow{2}{*}{$\frac{\begin{array}{c}\text { Volume } \\
\left(\mathrm{m}^{3} / \mathrm{MTHM}\right)\end{array}}{1.4 \times 10^{-1}}$} & \multicolumn{4}{|c|}{ Radionuclide Content } \\
\hline $\begin{array}{l}\text { Main plant venti- } \\
\text { lation filters (TRU) }\end{array}$ & Same as abo & & & & & $1 \times 10^{-5}$ & & $1 \times 10^{-5}$ \\
\hline $\begin{array}{l}\text { UF plant venti- } \\
\text { lation filters } \\
\text { (non-TRU) }\end{array}$ & Same as abo & & $1.6 \times 10^{2}$ & $5 \times 10^{-3}$ & & 0 & $\begin{array}{l}\text { U } \\
\text { A11 others }\end{array}$ & $\begin{array}{l}1 \times 10^{-5} \\
0\end{array}$ \\
\hline $\begin{array}{l}\mathrm{PuO}_{2} \text { conversion } \\
\text { ventilation } \\
\text { filters (TRU) }\end{array}$ & $\begin{array}{l}\text { Metal } \\
\text { Glass }\end{array}$ & $\begin{array}{l}60 \\
40\end{array}$ & $1.6 \times 10^{2}$ & $2 \times 10^{-2}$ & $\begin{array}{l}\mathrm{Zr}, \mathrm{Nb} \\
\mathrm{Ru}, \mathrm{Rh} \\
\mathrm{A} 11 \text { others }\end{array}$ & $\begin{array}{l}2.4 \times 10^{-6} \\
4.5 \times 10^{-3} \\
2 \times 10^{-7}\end{array}$ & $\begin{array}{l}\mathrm{U} \\
\mathrm{Pu} \\
\mathrm{A} 11 \text { others }\end{array}$ & $\begin{array}{l}7 \times 10^{-6} \\
5 \times 10^{-5} \\
2 \times 10^{-7}\end{array}$ \\
\hline $\begin{array}{l}\text { IX bead resins } \\
(T R U)\end{array}$ & $\begin{array}{l}\text { Polystyrene } \\
\mathrm{H}_{2} \mathrm{O}\end{array}$ & $\begin{array}{l}50 \\
50\end{array}$ & $7.2 \times 10^{2}$ & $5 \times 10^{-3}$ & $\begin{array}{l}{ }^{129} \mathrm{I} \\
\mathrm{Zr}, \mathrm{Nb} \\
\mathrm{Nb} \\
\mathrm{Ru}, \mathrm{Rh} \\
\mathrm{All} \text { others }\end{array}$ & $\begin{array}{l}2 \times 10^{-3} \\
1 \times 10^{-5} \\
1 \times 10^{-5} \\
1 \times 10^{-7}\end{array}$ & $\begin{array}{l}\mathrm{U} \\
\mathrm{Pu} \\
\mathrm{All} \text { others }\end{array}$ & $\begin{array}{l}1 \times 10^{-5} \\
1 \times 10^{-5} \\
1 \times 10^{-7}\end{array}$ \\
\hline $\begin{array}{l}\text { Degraded extract- } \\
\text { ant (TRU) }\end{array}$ & $\begin{array}{l}\text { TBP } \\
\text { Dodecane }\end{array}$ & $\begin{array}{l}30(\mathrm{vol}) \\
70(\mathrm{vol})\end{array}$ & $8 \times 10^{2}$ & $5 \times 10^{-2}$ & $\begin{array}{l}{ }^{129} \mathrm{I} \\
\mathrm{Zr}, \mathrm{Nb}, \mathrm{Ru} \\
\mathrm{Ru}, \mathrm{Rh} \\
\mathrm{All} \text { others }\end{array}$ & $\begin{array}{l}0.1 \\
5 \times 10^{-11} \\
5 \times 10^{-11} \\
5 \times 10^{-13}\end{array}$ & All others & $\begin{array}{l}1 \times 10^{-12} \\
2 \times 10^{-8} \\
5 \times 10^{-13}\end{array}$ \\
\hline
\end{tabular}

(a) Given as fraction of $\mathrm{Ci}$ values listed in Table C.3, exclude the volatile isotopes ${ }^{3} \mathrm{H}$ and ${ }^{85} \mathrm{Kr}$, also
$129_{\mathrm{I}}$ except as noted.

(b) Given as fraction of $\mathrm{Ci}$ values listed in Table C.2. 
TABLE C.15. Low-level Compactable Trash and Combustible Waste from Coprocessing Plant

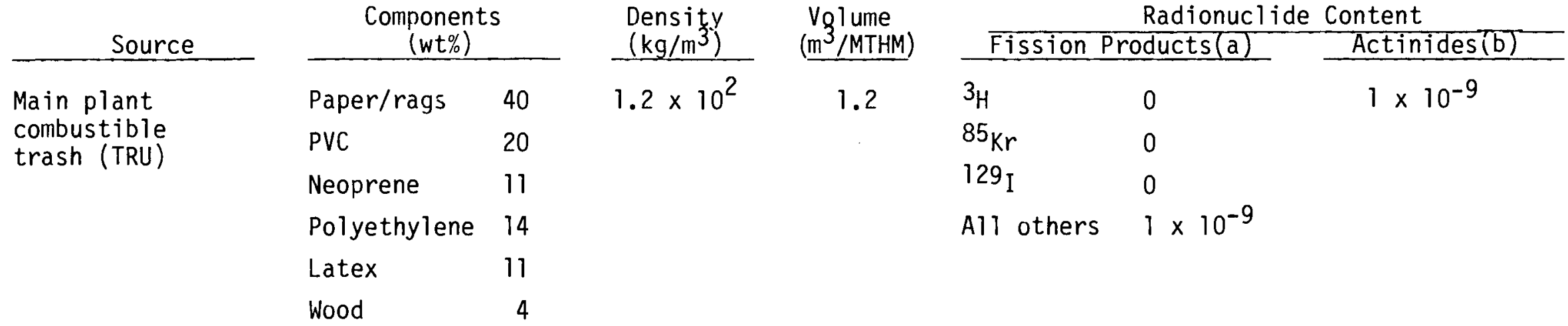

(a) Given as fraction of $\mathrm{C} i$ values listed in Table $\mathrm{C} .3$

(b) Given as fraction of $\mathrm{C} i$ values listed in Table C.2 
TABLE C.16. Transuranic Failed Equipment and Noncompactable, Noncombustible Trash from Coprocessing Plant

Source

\section{Main plant}

noncombustible

trash

$\mathrm{UF}_{6}$ plant noncombustible trash

$\mathrm{PuO}_{2}$ conversion noncombustible trash

Main plant

failed equipment

$\stackrel{i}{\perp} U_{6}$ plant failed equipment

$\mathrm{PuO}_{2}$ conversion

failed equipment

\begin{tabular}{lr}
\multicolumn{2}{c}{$\begin{array}{c}\text { Components } \\
(w t \%)\end{array}$} \\
\hline $\begin{array}{ll}\text { Ferrous } \\
\text { metal }\end{array}$ & 90 \\
Glass & 10
\end{tabular}

Same as above

Same as above

$2.5 \times 10^{2}$

$6 \times 10^{-3}$

$\mathrm{Zr}, \mathrm{Nb} \quad 5 \times 10^{-6}$

$\mathrm{Ru}$, Rh $4 \times 10^{-6}$

A11 others $5 \times 10^{-7}$

Ferrous $\quad 100 \quad 5 \times 10^{2} \quad 2 \times 10^{-1}$

alloys

Same as above

Same as above

\begin{tabular}{cc}
$\begin{array}{c}\text { Density } \\
\left(\mathrm{kg} / \mathrm{m}^{3}\right)\end{array}$ & $\begin{array}{l}\text { Volume } \\
\left(\mathrm{m}^{3} / \text { MTHM }\right)\end{array}$ \\
\hline
\end{tabular}

$2.5 \times 10^{2}$

$2.5 \times 10^{2}$

$1 \times 10^{-2}$

$1 \times 10^{-6}$

0

$5 \times 10^{2}$

$1 \times 10^{-2}$

$5 \times 10^{2}$

$2 \times 10^{-2}$

$\begin{array}{ll}\mathrm{Zr}, \mathrm{Nb} & 5 \times 10^{-6} \\ \mathrm{Ru}, \mathrm{Rh} & 4 \times 10^{-6}\end{array}$

$\mathrm{Ru}, \mathrm{Rh} 4 \times 10^{-6}$
$\mathrm{~A} 11$ others $5 \times 10^{-7}$

Radionuclide Content

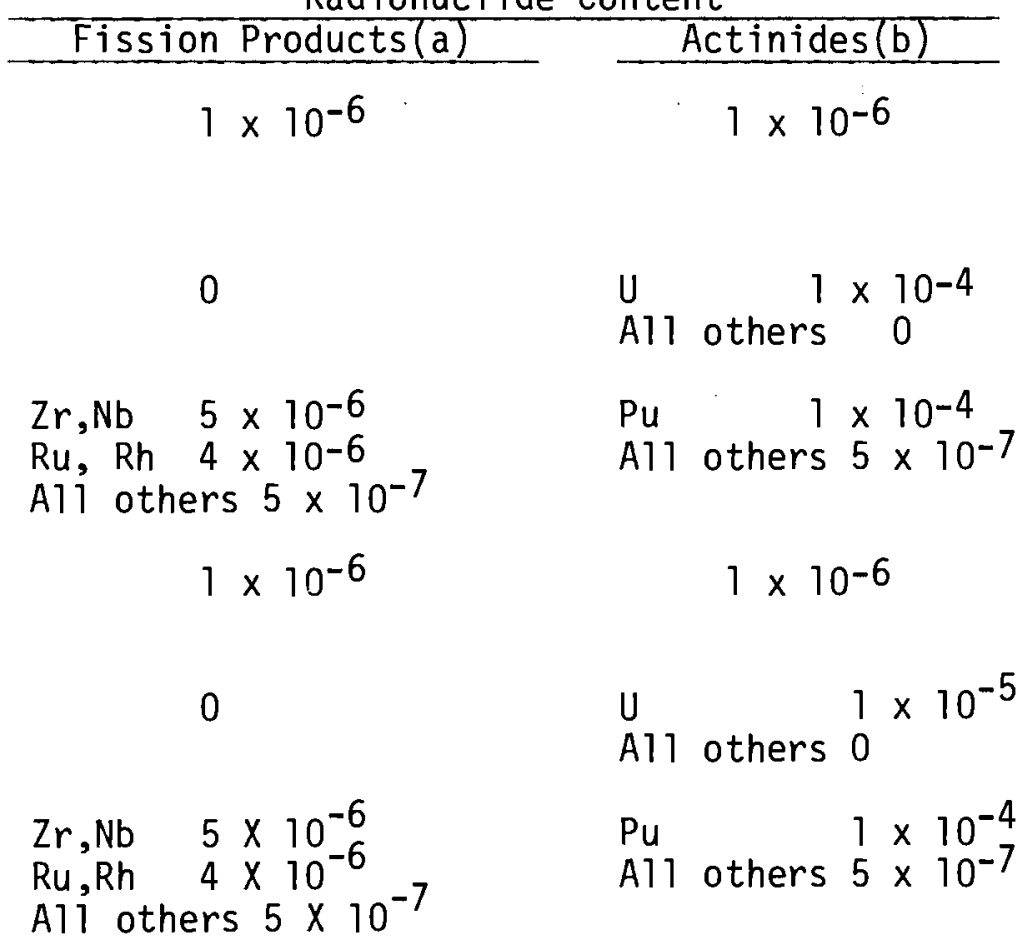

(a) Given as fraction of $\mathrm{Ci}$ values listed in Table C.3 exclude the volatile isotopes ${ }^{3} \mathrm{H},{ }^{85} \mathrm{Kr}$, and ${ }^{129} \mathrm{I}$.
(b)Given as fraction of $\mathrm{Ci}$ values listed in Table C.2. 
TABLE C.17. Nontransuranic Failed Equipment and Noncompactable, Noncombustible Waste from Coprocessing Plant

\begin{tabular}{|c|c|c|c|c|c|c|c|}
\hline \multirow{3}{*}{$\begin{array}{l}\text { Source } \\
\text { Storage basin non- } \\
\text { combustible trash }\end{array}$} & \multirow{2}{*}{\multicolumn{2}{|c|}{$\begin{array}{c}\text { Components } \\
(\text { wt } \%)\end{array}$}} & \multirow{2}{*}{$\begin{array}{l}\text { Densițy } \\
\left(\mathrm{kg} / \mathrm{m}^{3}\right) \\
\end{array}$} & \multirow{3}{*}{$\begin{array}{l}\begin{array}{l}\text { Volume } \\
\left(\mathrm{m}^{3} / M T H M\right)\end{array} \\
5 \times 10^{-2}\end{array}$} & \multicolumn{3}{|c|}{ Radionuclide Content } \\
\hline & & & & & \multicolumn{2}{|c|}{ Activation Products (a) } & \multirow{2}{*}{$\frac{\text { Fission Products }(a)}{6 \times 10^{-4}}$} \\
\hline & $\begin{array}{l}\text { Ferrous } \\
\text { metal }\end{array}$ & 90 & $2.5 \times 10^{2}$ & & $6 \times 10^{-4}$ & & \\
\hline & Glass & 10 & & & & & \\
\hline $\begin{array}{l}\text { Storage basin } \\
\text { failed equipment }\end{array}$ & $\begin{array}{l}\text { Ferrous } \\
\text { metal }\end{array}$ & 100 & $5 \times 10^{2}$ & $1 \times 10^{-2}$ & $8 \times 10^{-6}$ & & $8 \times 10^{-6}$ \\
\hline
\end{tabular}

(a)Given as fraction of $\mathrm{C} i$ values listed in Table C.6. 
TABLE C.18. Gaseous Waste from the Mixed 0xide Fuel Fabrication Plant

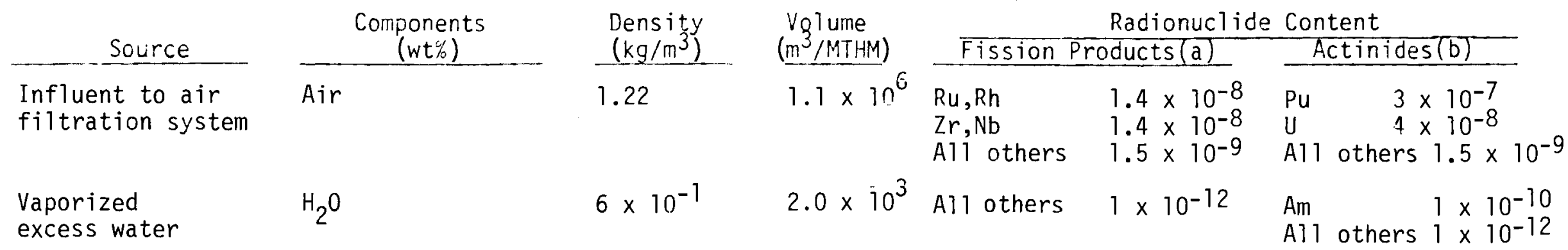

(a) Given as fraction of $\mathrm{Ci}$ values listed in Table C.3. (b) Given as fraction of $\mathrm{Ci}$ values listed in Table C.2. 
TABLE C.19. Compactable Trash and Combustible Waste from the Mixed Oxide Fuel Fabrication Plant

\begin{tabular}{|c|c|c|c|c|c|c|}
\hline & Componen & & Densiţy & $V_{Q}$ lume & Radionuclid: & Content \\
\hline Source & & & $\left(\mathrm{kg} / \mathrm{m}^{3}\right)$ & (mMTHM) & Fission Products $(a)$ & Actinides (b) \\
\hline HEPA filters & Metal & 60 & $1.6 \times 10^{2}$ & $1 \times 10^{-1}$ & $5 \times 10^{-6}$ & $1 \times 10^{-4}$ \\
\hline & Glass & 40 & & & & \\
\hline Combustible trash & PVC & 33 & $1.2 \times 10^{2}$ & $5 \times 10^{-1}$ & $3 \times 10^{-6}$ & $6 \times 10^{-5}$ \\
\hline & Cellulosics & 30 & & & & \\
\hline & Polyethylene & 18 & & & & \\
\hline & Latex & 9 & & & & \\
\hline & Neoprene & 9 & & & & \\
\hline & Styrene & 1 & & & & \\
\hline
\end{tabular}

(a) Given as fraction of $\mathrm{Ci}$ values listed in Table $\mathrm{C} .3$.
(b)Given as fraction of $\mathrm{C} i$ values listed in Table C.2. 
TABLE C.20. Concentrated Liquids, Wet Wastes, and Particulate Solids from the Mixed Oxide Fuel Fabrication Plant

\begin{tabular}{|c|c|c|c|c|c|c|}
\hline Source & Compo & & $\begin{array}{l}\text { Density } \\
\left(\mathrm{kg} / \mathrm{m}^{3}\right) \\
\end{array}$ & $\begin{array}{l}\text { Volume } \\
\left(\mathrm{m}^{3} / \text { MTHM }\right)\end{array}$ & $\frac{\text { Radionucl ide }}{\text { Fission Products }(a)}$ & $\frac{\text { Content }}{\text { Actinides(b) }}$ \\
\hline \multirow[t]{4}{*}{ Process solutions } & $\mathrm{Al}\left(\mathrm{NO}_{3}\right)_{3}$ & 16 & $1.2 \times 10^{3}$ & $2 \times 10^{-2}$ & $1 \times 10^{-7}$ & $2 \times 10^{-6}$ \\
\hline & $\mathrm{Ca}\left(\mathrm{NO}_{3}\right)_{2}$ & 6 & & & & \\
\hline & $\mathrm{CaF}_{2}$ & 0.2 & & & & \\
\hline & $\mathrm{H}_{2} \mathrm{O}$ & 78 & & & & \\
\hline \multirow{6}{*}{$\begin{array}{l}\text { Scrap recovery } \\
\text { solutions }\end{array}$} & $\mathrm{Al}\left(\mathrm{NO}_{3}\right)_{3}$ & 2 & $1.2 \times 10^{3}$ & $3.5 \times 10^{-1}$ & $2 \times 10^{-4}$ & $4 \times 10^{-3}$ \\
\hline & $\mathrm{Ca}\left(\mathrm{NO}_{3}\right)_{2}$ & 11 & & & & A11 others $2 \times 10^{-5}$ \\
\hline & $\mathrm{AlF}_{3}$ & 0.4 & & & & \\
\hline & $\mathrm{NH}_{4} \mathrm{NO}_{3}$ & 7 & & & & \\
\hline & $\mathrm{NaNO}_{3}$ & 7 & & & & \\
\hline & $\mathrm{H}_{2} \mathrm{O}$ & 73 & & & & \\
\hline
\end{tabular}

(a) Given as fraction of $\mathrm{Ci}$ listed in Table C.3.

(b) Given as fraction of $\mathrm{Ci}$ listed in Table C.2. 
TABLE C.21. Failed Equipment and Noncompactable, Noncombustible Waste from the Mixed Oxide Fuel Fabrication Plant

\begin{tabular}{|c|c|c|c|c|c|c|}
\hline & Compone & & Densiţy & VQlume & Radionuclide & Content \\
\hline Source & & & $(\mathrm{kg} /$ & & Fission Products (a) & Actinides (b) \\
\hline Noncombustible & Metal & 90 & $2.5 \times 10^{2}$ & $2 \times 10^{-1}$ & $1 \times 10^{-6}$ & $2 \times 10^{-5}$ \\
\hline trash & Glass & 10 & & & & \\
\hline Failed equipment & Metal & 80 & $1 \times 10^{3}$ & $2 \times 10^{-1}$ & $1 \times 10^{-7}$ & $2 \times 10^{-6}$ \\
\hline & $\begin{array}{l}\text { Insulating } \\
\text { brick }\end{array}$ & 20 & & & & \\
\hline
\end{tabular}

(a) Given as fraction of $\mathrm{Ci}$ listed in Table C.3.

(b) Given as fraction of $\mathrm{Ci}$ listed in Table C.2. 

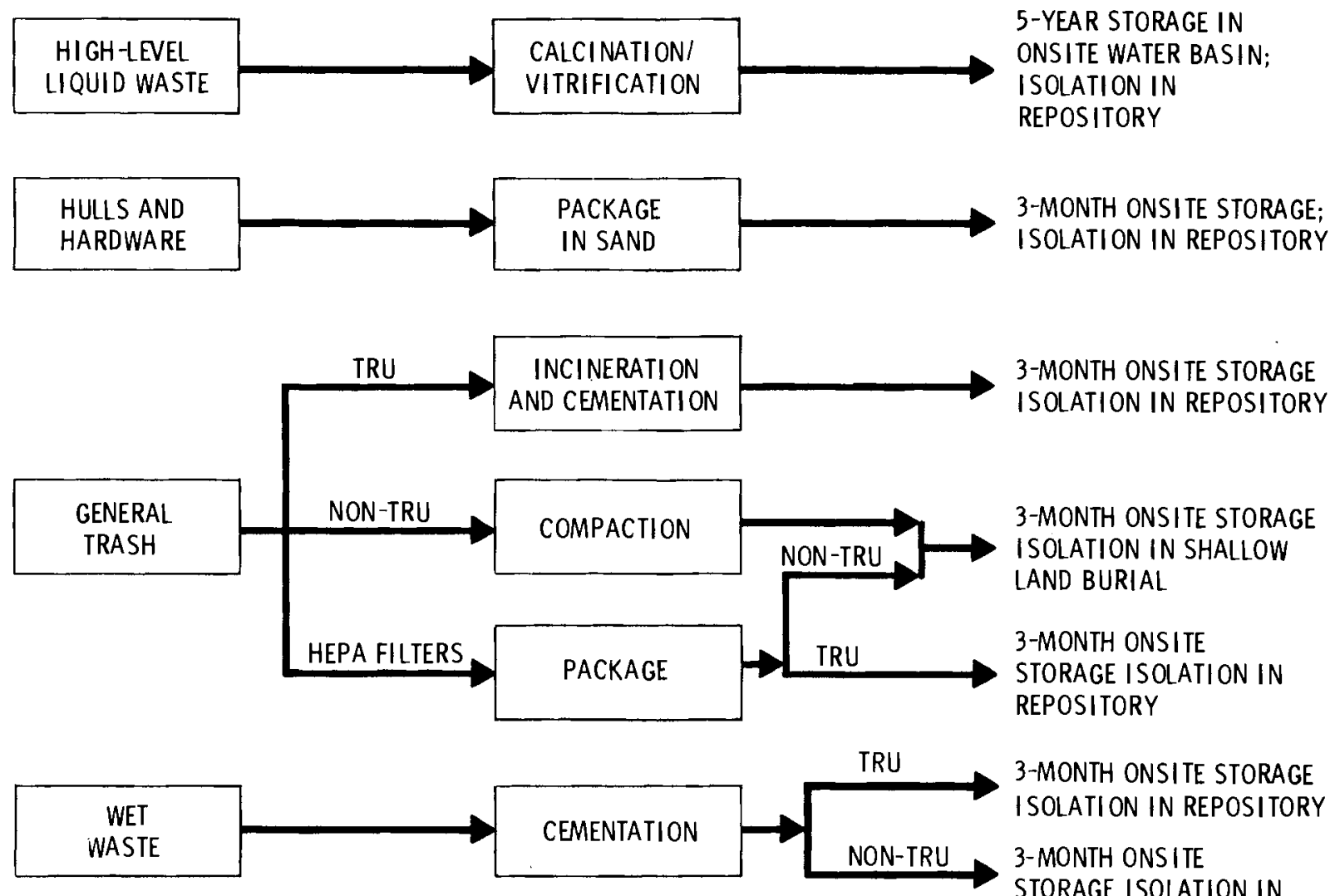

3-MONTH ONSITE STORAGE ISOLATION IN REPOSITORY

3-MONTH ONSITE STORAGE ISOLATION IN SHALLOW LAND BURIAL
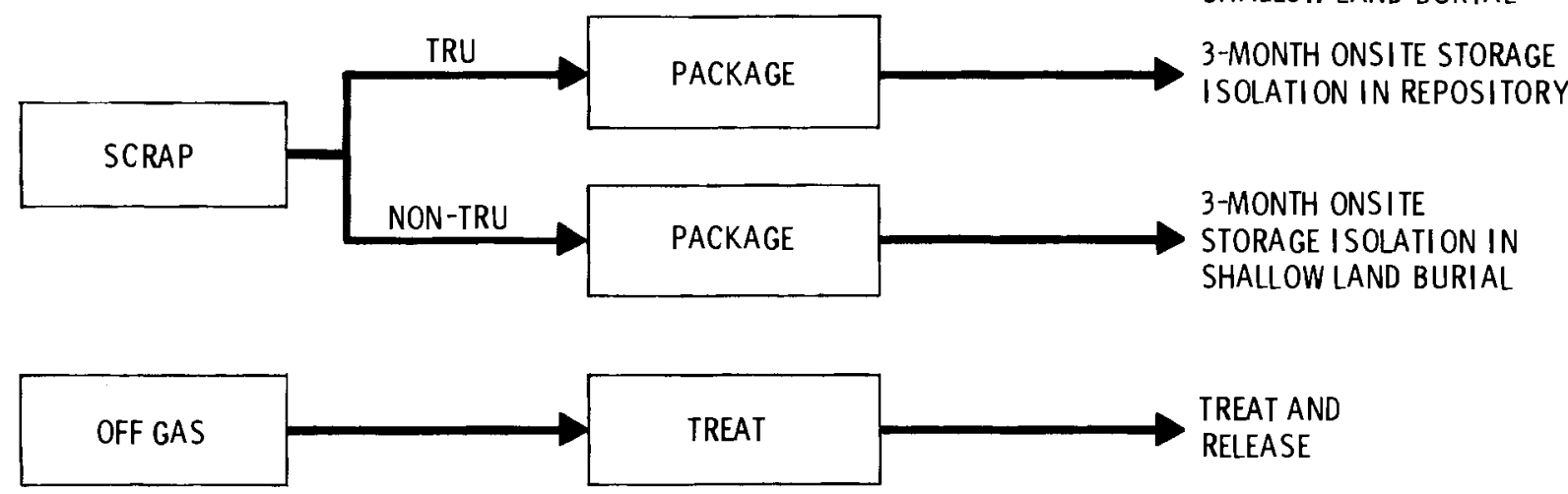

FIGURE C.7. Fuel Coprocessing Facility Radioactive Waste Management Strategy 
- Hulls and Hardware are packaged in carbon steel containers with sand as a filling matrix. The process is selected because of $i$ ts simplicity, and because other alternatives are not as developed. The process is totally remote. Waste containers are 30 inches in diameter and 10 feet long. Discussions of this treatment technology are found in references 18 and 19.

- General trash is treated in a variety of ways. The intermediate-level, TRU waste is incinerated in a remote facility. The ashes are immobilized in concrete. The off gas is scrubbed in a wet scrubber which generated a "blowdown" solution. The blowdown is concentrated and immobilized in cement. The low-level, TRU trash is also incinerated, although in a contact incineration system. The blowdown is concentrated with that of the intermediate-level waste. The incinerators are both controlled air systems. Incineration is selected because of the likely requirement of non-combustibility on wastes to be isolated in the repository. The nonTRU trash is compacted in a contact system. This treatment is selected because of its apparent low cost and simplicity, along with the resultant volume reduction. HEPA filters are packed in 80-gallon drums without treatment. TRU HEPA filters are packaged in a remote facility and nonTRU filters in a contact area. All wastes, except for the filters, are packaged in DOT certified 55-gallon drums. These treatment alternatives are discussed and described in detail in references 20-21 and 31-33.

- Wet wastes are immobilized in cement, utilizing a remote drum tumbling system. This treatment is selected because of the availability of the technology and the likely ban on combustible materials in the repository (which removes asphalt as a candidate wet waste binder). Both TRU and non-TRU wastes are immobilized in the same facility. Administrative controls will segrate the waste types. All wastes are packaged in 55-gallon drums. This waste processing technology is described in detail in references $34-38$. 
Scrap is decontaminated, disassembled if necessary, and packaged in 55-galion drums. The process is selected because of its simplicity. TRU and non-TRU scrap are packaged in different facilities, remote and contact, respectively. Scrap processing is described in references 39 and 40 .

- Off-gas treatment varies depending on the expected level of radioactive contamination. Fuel shear and dissolver off gas is screened, condensed, scrubbed, of iodine with silica gel, passed through an $\mathrm{NO}_{\mathrm{x}}$ absorber, and routed to the vessel off-gas system. Noble gas, tritium and carbon-14 retention systems are not addressed here and are adequately examined in reference 41 . The vessel off gas is condensed, scrubbed of iodine with silica gel, filtered for particulates, scrubbed for iodine with silica gel, filtered for particulates, scrubbed for iodine again, filtered for particulates again, diluted with stack exhaust, and discharged. The main plant HVAC is filtered for particulates, diluted with stack exhaust, and discharged. Excess water is evaporated in the excess water vaporizer, diluted with stack exhaust, and discharged. $U_{6}$ plant process off gas is filtered for particulates, diluted with stack exhaust, and discharged, as is storage basin HVAC. Mixed nitrate calciner off gas is condensed, scrubbed of ruthenium, filtered for particulates, scrubbed of iodine and $\mathrm{NO}_{x}$, filtered for particulates again, diluted with stack exhaust and discharged. Off-gas treatment technology is discussed in detail in references 41 and 42 .

\section{Mixed Oxide Fuel Fabrication Facility Waste Treatment}

The overall radioactive waste management strategy for the MOX facility wastes is shown in Figure C.8. Each waste stream is discussed below with many of the details for the coprocessing facility waste treatments applying here. All packaged wastes may be stored onsite for three months in a treatment surge storage areas. 


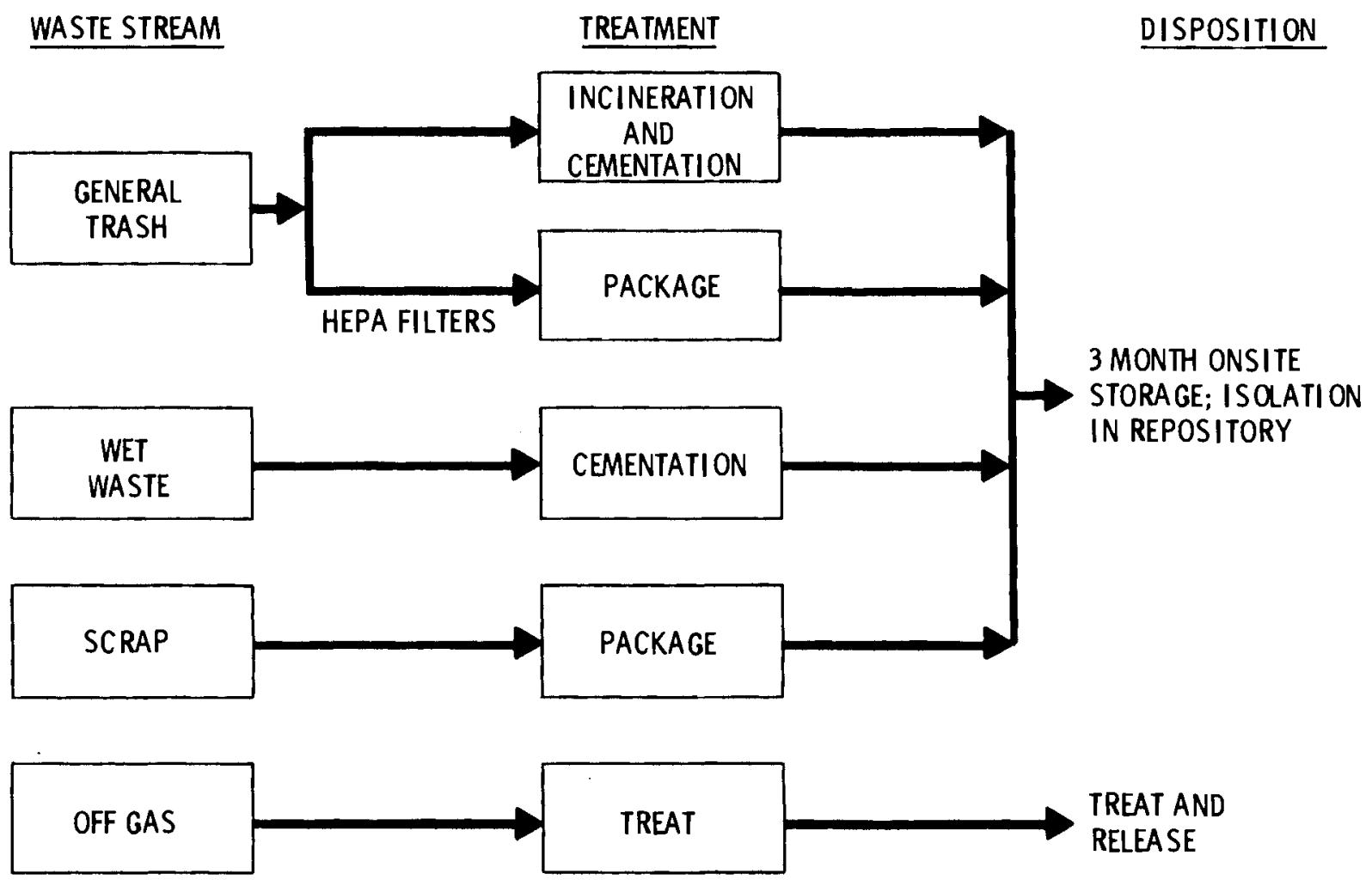

FIGURE C.8. Mixed Oxide Fuel Fabrication Facility Radioactive Waste Management Strategy

- General trash is treated by incineration and cement immobilization except for HEPA filters which are packaged (references 20, 21 and 31-33).

- Wet wastes are immobilized in cement (references 34-38).

- Scrap is decontaminated, disassembled and packaged (references 39 and 40).

- Off gas is filtered through several HEPA banks to remove particulates, diluted with stack exhaust, and discharged (references 41 and 42). 


\section{REFERENCES}

1. U.S. Department of Energy Division of Nuclear Research and Applications, Nuclear Energy Assessments, Nonprol iferation Alternative Systems Assessment Program: Final Program Plan - For Management Review. September 15, 1977.

2. M. Levenson and B. A. Hutchins, Denatured Plutonium - A Study of Deterrent Action. Electric Power Research Institute Report EPRI-310, July 1975.

3. W. J. Zielenbach et al., Evaluation on Effluent Streams from Reprocessing and Fabrication for BCL Concept of an LWR Coprocessing Fuel Cycle. Battelle Columbus Report for PNL, JuTy 1978.

4. M. Pobereskin et al., Coprocessing - An Evaluation of Chemical Reprocessing Without Plutonium Separation. Battelle Columbus Laboratories, BMI-EQAC-1, October 1977.

5. M. J. Bell, ORIGEN--The ORNL Isotope Generation and Depletion Code. ORNL-4628, May 1973.

6. Technology for Commercial Radioactive Waste Management. DOE-ET-0028, Prepared by Pacific Northwest Laboratory, 1979.

7. Allied Gulf Nuclear Services, Barnwell Nuclear Fuels Plant Separations Facility, Final Safety Analysis Report. Section 4 and 5, Docket 50-332.

8. Alternatives for Managing Wastes from Reactors and Post-Fission Operations in the LWR Fuel Cycle. ERDA-76-43, Prepared by Pacific Northwest Laboratory, May, 1976 (Commonly known as the Technical Alternatives Document, TAD).

9. Westinghouse Nuclear Fuel Division, Recycle Fuels Plant License Application. Section 5.8, Docket-701432-2, July 1973.

10. Purex Technical Manual. Hanford Atomic Products Operation, HW 31000, Richland, WA, March 1955.

11. M. S. Okamoto and M. C. Thompson, "Coprocessing Solvent Extraction Studies." Nuclear Technology. DP-MS-77-76, Dupont, Savannah River Laboratory, 1977.

12. Final Generic Environmental Statement on the Use of Recycle Plutonium in Mixed Oxide Fuel in Light Water Cooled Reactors. PB-256484, Nuclear Regulatory Commission, August 1976.

13. "Alternate Fuel Cycle Technologies." Savannah River Laboratory, Quarterly Report, July-September 1977. DPST-AFCT-77-1-3, pp. 65-70, December 1977. 
14. R. J. Sload, W. A. Graf, Jr. and G. P. Miller, Criteria and Concepts for Coprecal Conversion in an LWR Fuel Reprocessing-Refabrication Plant

Complex. Spent Fuel Services Operation, NED0-21822. General Electric Company.

15. D. J. Crouse, Advanced Fuel Recycle Program Progress Report for Period January 1 to March 31, 1978. Product Conversion, ORNL/TM-6306, May 1978.

16. D. E. Larson, W. F. Bonner, High Level Waste Vitrification by Spray Calcination and In Can Melting. BNWL-2092. Pacific Northwest Laboratory, November 1976.

17. J. L. McElroy, Quarterly Progress Report, Research and Development Activities, Waste Fixation Program, October through December, 1977. PNL-2265-4, Pacific Northwest Laboratory, March 1979.

18. Reference 6, Section 4.2.

19. Reference 8, Section 7 .

20. Reference 6, Section 4.4.

21. Reference 8, Section 9.

22. Nuclear Fuel Recovery and Recycling Center Prel iminary Safety Analysis Report. XN-FR-32, Docket 50-564, Exxon Nuclear Co., Inc., Richland, WA, 1976.

23. Reference 6, Section 4.1 and Section 5.4 .

24. D. E. Larson et a1., Conceptual Design of a Nuclear Waste Vitrification Facility. PNL-2690, Pacific Northwest Laboratory, May 1978.

25. Reference 8, Section 6 .

26. J. L. McElroy, Quarterly Progress Report, Research and Development Activities, Waste Fixation Program, July through September, 1977. PNL-2265-3, Pacific Northwest Laboratory, October 1978.

27. J. E. Mendel et a1., High-Level Radioactive Waste Immobilization Alternatives. Part 2, BNWL-1909, Pacific Northwest Laboratory, July 1975.

28. J. E. Mendel, The Storage and Disposal of Radioactive Waste as Glass in Canisters. PNL-2764, Pacific Northwest Laboratory, December, 1978.

29. J. E. Mende1, Nuclear Waste Disposa1. PNL-SA-7602, Pacific Northwest Laboratory, March 1979. 
30. K. J. Schneider and A. M. Platt, eds., High-Level Radioactive Waste Management Alternatives, BNWL-1900, Pacific Northwest Laboratory, May 1974.

31. Atomic Energy Commission, Compaction of Radioactive Solid Waste. WASH-1167, Washington DC, June 1970.

32. Atomic Energy Commission, Incineration of Radioactive Solid Wastes. WASH-1168, Washington DC, August, 1970.

33. D. L. Ziegler et al., Status Report--Waste Incineration and Fixation for Waste Management, Production and Reprocessing for the Department of Energy. RFP-2655, November, 1977.

34. Reference 6, Section 4.7.

35. Reference 8, Section 12 .

36. J. W. Voss, "Comparison of Bitumen and Cement Immobilization of Intermediate- and Low-Level Radioactive Waste." Proceedings of the Waste Management ' 79 Symposium, Tucson, AZ, February 1979.

37. J. R. Stock and P. C. Williams, "A Solid Radwaste System Utilizing Cement." ANS Winter Meeting transactions, November, 1978.

38. R. H. Burns, "Solidification of Low- and Intermediate-Level Wastes." Atomic Energy Review, 9 (3), 1971.

39. Reference 6, Section 4.3.

40. Reference 8, Section 8.

41. Reference 6 , Sections $4.8,4.9,4.10$ and 4.11 .

42. Reference 8, Section 13. 
1 
PNL-3153

UC-70

\section{DISTRIBUTION}

No. of

Copies

OFFSITE

United States

A. A. Churm

DOE Chicago Patent Group

9800 South Cass Avenue

Argonne, IL 60439

334 DOE Technical Information Center

G. Oertel

DOE Office of Nuclear Waste

Management

Washington, DC 20545

A. F. Perge

DOE Office of Nuclear Waste

Management

Washington, DC 20545

C. R. Cooley

DOE Office of Nuclear Waste

Management

Washington, DC 20545

Battelle Memorial Institute

Office of Nuclear Waste Isolation

Attn: Ms. Beverly Rawles

505 King Avenue

Columbus, $\mathrm{OH} 43201$

N. E. Carter

Battelle Project Management Division

Battelle Memorial Institute

505 King Avenue

Columbus, $\mathrm{OH} 43201$

R. Williams

Electric Power Research Institute $3412 \mathrm{Hillview}$ Avenue

P.0. Box 10412

Palo Alto, CA 94304
No. of

Copies
W. S. Durant

duPont Company, Aiken (U.S. DOE)

E. I. duPont DeNemours and Co.

Savannah River Laboratory

Aiken, SC 29801

D. Egan

Environmental Protection Agency

5207 Longsdale Drive

Springfield, VA 22151

R. C. Erdmann

Science Application, Inc.

2680 Hanover Street

Palo Alto, CA 94303

T. H. Smith

EG\&G Company

Idaho Falls, ID 83401

M. C. Cullingford

NRC Office of Nuclear Regulatory Research

Washington, DC 20545

Foreign

International Atomic Energy Agency Kärtner Ring 11

P.0. Box 590

A-1011, Vienna, AUSTRIA

Center for Atomic Energy

Documentation (ZAED)

Attn: Dr. Mrs. Bell

P.0. Box 3640

$7500 \mathrm{Karls}$ ruhe

GERMANY 
No. of

Copies

H. Krause

Kernforschungszentrum Karlsruhe GmbH (KfK)

Postfach 3640

D7500 Karlsruhe

GERMANY

N. S. Sunder Rajan

Bhabha Atomic Research Centre

Waste Treatment Division

Trombay, Bombay, 400085 INDIA

ONSITE

DOE Richland Operations

P. A. Craig

H. E. Ransom

M. W. Shupe

Rockwe11 Hanford Company

R. E. Isaacson

D. Wood

Pacific Northwest Laboratory

N. M. Burleigh

J. Greenborg

R. C. Liikala

S. E. Lyke

P. J. Pelto (23)

A. M. Platt

R. E. Rhoads

J. V. Robinson

J. W. Voss

E. C. Watson

L. D. Williams

W. K. Winegardner (5)

Publishing Coordination (2)

Technical Information (5)

$\mathrm{Ma}$ 